\author{
UNIVERSIDADE DE SÃO PAULO \\ INSTITUTO DE FÍSICA \\ INSTITUTO DE QUÍMICA \\ INSTITUTO DE BIOCIÊNCIAS \\ FACULDADE DE EDUCAÇÃO
}

ANDRÉ FELIPE RODRIGUES

A pesquisa em alfabetização científica no Brasil: uma análise da produção acadêmica no período de 2013 a 2017

Ribeirão Preto

2020 



\section{ANDRÉ FELIPE RODRIGUES}

\section{A pesquisa em alfabetização científica no Brasil: uma análise da produção acadêmica no período de 2013 a 2017}

\section{Versão Original}

Dissertação de mestrado apresentada ao Instituto de Química, Instituto de Física, Instituto de Biociências e à Faculdade de Educação da Universidade de São Paulo.

Área de Concentração: Ensino de Química.

Orientador: Mauricio dos Santos Matos

Ribeirão Preto 
Autorizo a reprodução e divulgação total ou parcial deste trabalho, por qualquer meio convencional ou eletrônico, para fins de estudo e pesquisa, desde que citada a fonte.

FICHA CATALOGRÁFICA

Preparada pelo Serviço de Biblioteca e Informação do Instituto de Física da Universidade de São Paulo

Rodrigues, André Felipe

A pesquisa em alfabetização científica no Brasil: uma análise da produção acadêmica no período de 2013 a 2017 . São Paulo, 2020.

Dissertação (Mestrado) - Universidade de São Paulo. Faculdade de Educação. Instituto de Física. Instituto de Química e Instituto de Biociências

Orientador: Prof. Dr. Maurício dos Santos Matos

Área de Concentração: Química

Unitermos: 1. Química - Estudo e Ensino; 2. Alfabetização Científica; 3. Ensino de Ciência; 4. Estado do Conhecimento; 5. Estado da Arte .

USP/IF/SBI-006/2020 
Dedico este trabalho aos meus pais, Wanderley Rodrigues e Diva Gasperini Rodrigues, que foram e continuam sendo as pessoas mais importantes na minha vida, e às minhas avós, Maria Helena Luvizuto Gasperini e Lourdes André Rodrigues, que sempre me incentivaram a trilhar o caminho de formação no Ensino Superior. 


\section{AGRADECIMENTOS}

A Deus e à minha família, pelo suporte em minha vida.

À minha namorada, pelo suporte emocional para vencer mais esta etapa.

Ao professor Mauricio dos Santos Matos, pela orientação, incentivo e suporte em minha formação acadêmica.

Às professoras Lilian Al-Chueyr Pereira Martins e Clarice Sumi Kawasaki e ao professor Danilo Kato, pelas importantes contribuições para este trabalho.

Aos Professores das disciplinas que cursei durante a Pós-graduação, pela formação e aprendizagem durante todo o processo.

Aos colegas de Pós-graduação e do Grupo de Pesquisa Ciências, Comportamento e Ambiente, pelo tempo de convivência, aprendizagem conjunta e socialização de experiências, informações, alegrias e tristezas.

Ao Programa de Pós-Graduação Interunidades em Ensino de Ciências, pela oportunidade concedida a mim e toda estrutura disponibilizada.

À CAPES, pela bolsa fornecida e suporte durante toda a minha jornada na pesquisa. 
"O ser humano é um ser que se caracteriza por pensar, sentir e fazer." (MOREIRA \& OSTERMANN, 1993, p. 116) 


\section{RESUMO}

RODRIGUES, André Felipe. A pesquisa em alfabetização científica no Brasil: uma análise da produção acadêmica no período de 2013 a 2017. 2020. 176 f. Dissertação (Mestrado em Ensino de Ciências, modalidade Ensino de Química) - Instituto de Física, Instituto de Química, Instituto de Biociências, Faculdade de Educação, Universidade de São Paulo, São Paulo, 2020.

Esta pesquisa foi desenvolvida com o objetivo de caracterizar o conjunto de teses e dissertações defendidas no Brasil, no período de 2013 a 2017, que mostraram algum tipo de apropriação da temática da alfabetização científica (AC), buscando reconhecer possíveis tendências, movimentos e características específicas dessa produção, principalmente em relação à apropriação dos eixos estruturantes da AC. A pesquisa foi desenvolvida dentro de uma abordagem qualitativo-quantitativa, a partir da recuperação da produção em AC no banco de teses e dissertações da CAPES, caracterizando essa produção a partir do uso de descritores definidos a posteriori e outros consolidados na literatura. As categorias utilizadas para a caracterização dessa produção acadêmica foram construídas a partir de uma análise categorial usando a análise de conteúdo. A análise foi feita a partir da leitura e releitura dos resumos, usando unidades de análise e assumindo o texto do resumo como unidade de contexto. Como resultado, observou-se que a presença da expressão "alfabetização científica" nas produções acadêmicas em nível de pós-graduação mostrou ser muito superior à presença das expressões "letramento científico" e "enculturação científica". Todavia, essa característica não foi reconhecida como uma particularidade da produção acadêmica analisada, já que foi também observada em outros tipos de produção, validando as teses e dissertações como um sistema representativo para reconhecimento de movimentos e tendências da produção científica em AC. Em termos da natureza da produção acadêmica em AC, 70,29\% dessa produção está concentrada na área de Ensino, apresentando características muito similares à produção nessa área do conhecimento. A análise das características mais internas das pesquisas em AC mostrou que a abordagem qualitativa está presente na maior parte da produção analisada. No que se refere às formas de apropriação do conhecimento científico como um dos eixos estruturantes da AC, observou-se uma apropriação significativa do caráter interdisciplinar, estando este muito associado à presença de temáticas ambientais. Em relação à apropriação do eixo "natureza da Ciência", identificou-se a presença deste eixo em apenas 10,87\% da produção acadêmica em AC, sugerindo que a "Natureza da Ciência" (NC), principalmente em sua dimensão histórica, tem sido pouco privilegiada nas pesquisas em AC. Já em relação à apropriação da "contextualização" como um dos eixos estruturantes da AC, o cotidiano e as relações Ciência, Tecnologia e Sociedade (CTS) foram as duas formas de contextualização mais recorrentes nos resumos analisados. O conjunto de resultados obtidos nesse estudo possibilitou a identificação de algumas características e apropriações das produções acadêmicas em AC. No entanto, essa caracterização ainda se mostrou limitada, necessitando que sejam conduzidos outros estudos que possam ampliar essa análise para além dos resumos das produções em AC, assumindo o texto completo dessas produções acadêmicas como sistema de análise, o que possibilitará uma visão mais nítida dessa produção, principalmente em relação às tendências nas pesquisas em AC.

Palavras-chave: Alfabetização científica. Ensino de ciências. Estado do conhecimento. Estado da Arte. 


\begin{abstract}
RODRIGUES, André Felipe. Research in scientific literacy in Brazil: analysis of the academic production from 2013 to 2017. 2020. 176 f. Dissertation (Master in Science Teaching, Chemistry Teaching modality) - Institute of Physics, Institute of Chemistry, Institute of Biosciences, Faculty of Education, University of de São Paulo, São Paulo, 2020.
\end{abstract}

This research was developed with the objective of characterizing the set of theses and dissertations defended in Brazil from 2013 to 2017, which showed some type of appropriation of the theme of scientific literacy (SL), seeking to recognize possible trends, movements and specific characteristics of this production, mainly in relation to the appropriation of the structuring axes of SL. The study was developed within a qualitative-quantitative approach, based on the recovery of production in SL in the CAPES theses and dissertations database, characterizing this production from the use of descriptors defined a posteriori and others consolidated in the literature. The categories used for the characterization of this academic production were constructed from a category analysis using content analysis. The analysis was made from the reading and rereading of abstracts, using units of analysis and assuming the abstract text as a unit of context. As a result, it was observed that the presence of the expression "scientific literacy" in academic productions at the graduate level proved to be much higher than the presence of the expressions "scientific literacy" and "scientific enculturation". However, this characteristic was not recognized as a particularity of the academic production analyzed, since it was also observed in other types of production, validating theses and dissertations as a representative system for the recognition of movements and trends of scientific production in SL. In terms of the nature of academic production in SL, $70.29 \%$ of this production is concentrated in the teaching area, presenting characteristics very similar to the production in this area of knowledge. The analysis of the most internal characteristics of the research in SL showed that the qualitative approach is present in most of the analyzed production. In relation to the forms of appropriation of scientific knowledge as one of the structuring axes of SL, a significant appropriation of the interdisciplinary character was observed, being very associated with the presence of environmental themes. Regarding the appropriation of the "nature of science" axis, the presence of this axis was identified in only $10.87 \%$ of the academic production suggesting that the "Nature of Science" (NC), especially in its historical dimension, has been little privileged in research in SL. In relation to the appropriation of "contextualization" as one of the structuring axes of SL, "daily life" and the relations Science, Technology, Society (STS) were the two most recurrent forms of contextualization in the abstracts analyzed. The set of results obtained in this study allowed the identification of some characteristics and appropriations of academic productions in SL. However, this characterization was still limited, requiring further studies to be conducted that can expand this analysis beyond the abstracts of the productions in SL, assuming the full text of these academic productions as a system of analysis, which will allow a clearer view of this production, especially in relation to trends in research in SL.

Keywords: Scientific literacy. Science teaching. State of knowledge. State of Art. 


\section{LISTA DE TABELAS}

Tabela 1 Distribuição, por ano de defesa, do conjunto de 324 teses e dissertações, defendidas no Brasil no período de 2013 a 2017, nas quais foram identificadas a presença dos termos "alfabetização científica", "letramento científico" e "enculturação científica" em algum dos campos de indexação (título, resumo, palavras-chave).

Tabela 2 Distribuição do conjunto de visualizações resultantes da busca de produções no google acadêmico, no período de 2013 a 2017, a partir do uso dos termos "alfabetização científica", "letramento científico" e "enculturação científica" no campo de busca.

Tabela 3 Distribuição, por ano de defesa, do conjunto de 276 teses e dissertações, defendidas no Brasil no período de 2013 a 2017, que mostraram se apropriar da alfabetização científica em sua pesquisa e que constitui o corpus documental da pesquisa.

Tabela 4 Distribuição, por ano de defesa, do conjunto de 276 teses e dissertações, defendidas no Brasil no período de 2013 a 2017, na área de Ensino.

Tabela 5 Caracterização por grande região e estado.

Tabela 6 Distribuição, por grande região e estado, de toda a produção de teses e dissertações da área de Ensino.

Tabela 7 Caracterização da produção acadêmica em AC por Instituição de Ensino Superior.

Tabela 8 Caracterização da produção acadêmica em AC por grande área e área do conhecimento.

Tabela 9 Caracterização da produção acadêmica em AC por tipo de produção e grau acadêmico.

Tabela 10 Caracterização, por grau acadêmico, de toda produção acadêmica na área de Ensino.

Tabela 11 Abordagens da pesquisa explicitadas nos resumos de teses e dissertações em AC.

Tabela 12 Características das pesquisas explicitadas nos resumos analisados.

Tabela 13 Caracterização dos diferentes tipos de organização do conhecimento identificados nas pesquisas em Alfabetização Científica.

Tabela 14 Caracterização dos temas interdisciplinares identificados nas pesquisas em Alfabetização Científica.

Tabela 15 Caracterização da apropriação do eixo "Natureza da Ciência" pelas pesquisas em Alfabetização Científica.

Tabela 16 Caracterização da apropriação do eixo "Contextualização" pelas pesquisas em Alfabetização Científica. 


\section{SUMÁRIO}

1 NATUREZA, ESTRUTURA E ORGANIZAÇÃO DA DISSERTAÇÃO

2 CONTEXTUALIZAÇÃO DA PESQUISA A PARTIR DA MINHA TRAJETÓRIA PESSOAL E PROFISSIONAL

3 INTRODUÇÃO

3.1 UMA BREVE REVISÃo bibLIOGRÁFICA dos Estudos de ESTAdo dA ARTE E ESTAdo do ConHECIMENTO RELACIONAdos À TEMÁTICA DE

$\begin{array}{lr}\text { ALFABETIZAÇÃO CIENTÍFICA NO BRASIL } & 20\end{array}$

$\begin{array}{lr}3.2 \text { PROBLEMATIZAÇÃOO } & 22\end{array}$

$\begin{array}{lr}3.3 \text { OBJETIVOS } & 25\end{array}$

$\begin{array}{lr}4 \text { REFERENCIAL TEÓRICO } & 27\end{array}$

$\begin{array}{lr}\text { 4.1 AlFabetizaÇão Científica } & 27\end{array}$

4.2 EIXOS ESTRUTURANTES DA ALFABETIZAÇÃO CIENTÍFICA

4.2.1 Conhecimento Científico 33

4.2.1.1. Caracterização e diferenciação em relação a outros tipos de conhecimento 33

4.1.1.2 O conhecimento escolar como a verdadeira identidade do conhecimento científico transposto didaticamente ou recontextualizado $\quad 35$

4.2.1.3. A organização e interação dos saberes 38

4.2.2 Natureza da Ciência $\quad 40$

4.2.2.1 A Natureza da Ciência e sua relação com a História da Ciência 40

4.2.2.2 A Natureza da Ciência e as características específicas e gerais da Ciência 41

$\begin{array}{ll}4.2 .3 \text { Contextualização } & 45\end{array}$

4.2.3.1 A importância da contextualização para a significação dos conceitos 46

4.2.3.2 A contextualização na perspectiva das relações entre Ciência, Tecnologia, Sociedade e Ambiente 47

5 METODOLOGIA

5.1 ABORDAGEM DA PESQUISA E A OPÇÃO PELA ANÁLISE DE CONTEÚDO

5.2 AS ETAPAS DO PERCURSO METODOLÓGICO

5.3 ETAPA 1: A ESCOLHA DA BASE DE DADOS, DO PERÍODO E DO TIPO DE MATERIAL A SER ANALISADO

5.3.1 A escolha da base de dados de Teses e Dissertações da CAPES

5.3.2 A definição do período analisado

5.3.3 A opção pelo resumo como material a ser analisado para caracterização das produções acadêmicas 56

5.4 ETAPA 2: RECUPERAÇÃO dO CONJUNTO TOTAL (CONJUNTO A) DE RESUMOS DE TESES E DISSERTAÇõES DEFENDIDAS NO PERÍOdO DE

2013 A $2017 \quad 56$

5.5 ETAPA 3: CARACTERIZAÇÃo GERAL DO CONJUNTO A de RESUMOS

5.6 ETAPA 4: SELEÇÃo E ANÁLISE dO CONJUNTO DE RESUMOS DE TESES E DISSERTAÇÕES (CONJUNTO B) NAS QUAIS ALGUMA DAS

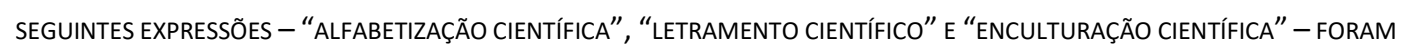

$\begin{array}{lr}\text { IDENTIFICADAS } & 58\end{array}$

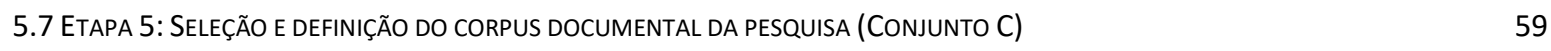

5.8 ETAPA 6: CARACTERIZAÇÃO DO CORPUS DOCUMENTAL DA PESQUISA (CONJUNTO C) 60 
5.8.1 Etapa 6a: Caracterização do total de produção e do contexto de produção

5.8.2 Etapa 6b: Caracterização do tipo de produção 61

5.8.3 Etapa 6c: Caracterização das pesquisas associadas à produção 61

5.9 ETAPA 7: CARACTERIZAÇÃO DA APROPRIAÇÃO DOS TRÊS EIXOS ESTRUTURANTES DA AC 62

5.9.1 Etapa 7a: Análise da apropriação do eixo "conhecimento científico" 62

5.9.2 Etapa 7b: Análise da apropriação do eixo "contextualização" 63

5.9.3 Etapa 7c: Análise da apropriação do eixo "Natureza da Ciência" 64

$\begin{array}{lr}6 \text { RESULTADOS E DISCUSSÃO } & 65\end{array}$

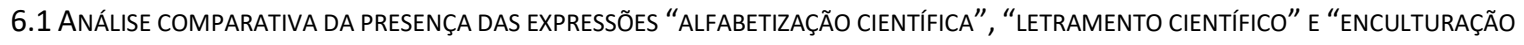
CIENTíFICA" CITADAS NO TítULO, RESUMO OU PALAVRAS-CHAVE DE TESES E DISSERTAÇÕES DEFENDIDAS NO BRASIL, NO PERÍODO DE 2013 A 2017

6.2 IDENTIFICAÇÃO DO CORPUS DOCUMENTAL DA PESQUISA E RECONHECIMENTO DO TOTAL DE PRODUÇÃO EM AC NO PERÍOdO DE 2013 A

6.3 CARACTERIZAÇÃO DO CONJUNTO DE TESES E DISSERTAÇõES EM ALFABETIZAÇÃO CIENTíFICA, DEFENDIDAS NO BRASIL, NO PERÍOdO DE 2013 A 2017 70

6.3.1 Caracterização do contexto de produção $\quad 70$

6.3.1.1 Caracterização por grande região e estado 70

6.3.1.2 Caracterização por Instituição de Ensino Superior (IES) 73

6.3.2 Caracterização da natureza da produção $\quad 75$

6.3.2.1 Caracterização por grande área e área do conhecimento $\quad 75$

6.3.2.2 Caracterização por tipo de produção e grau acadêmico 76

6.4 IDENTIFICAÇÃO DAS CARACTERÍSTICAS MAIS INTERNAS E PARTICULARES DAS PESQUISAS EM AC 77

$\begin{array}{ll}\text { 6.4.1 Identificação das abordagens utilizadas nas pesquisas } & 78\end{array}$

$\begin{array}{ll}6.4 .2 \text { Identificação de outras características das pesquisas } & 78\end{array}$

6.5 CARACTERIZAÇÃO DAS PESQUISAS EM TERMOS DA APROPRIAÇÃO DE CADA UM DOS TRÊS EIXOS ESTRUTURANTES DA ALFABETIZAÇÃo $\begin{array}{ll}\text { CIENTÍFICA } & 80\end{array}$

6.5.1 Análise da apropriação do eixo "Conhecimento Científico" nas pesquisas em AC 80

6.5.2 Análise da apropriação do eixo "Natureza da Ciência" nas pesquisas em AC 82

6.5.3 Análise da apropriação do eixo "contextualização" nas pesquisas em AC 84

\begin{tabular}{l}
7 CONCLUSÃO \\
\hline
\end{tabular}

\begin{tabular}{l} 
REFERÊNCIAS \\
\hline
\end{tabular}

$\begin{array}{lr}\text { ANEXOS } & 101\end{array}$

Anexo A - Metadados do Catálogo de Teses e Dissertações da Capes, Dados das Teses e Dissertações da

$\begin{array}{ll}\text { Pós-Graduação } 2013 \text { a } 2016 . & 101\end{array}$

Anexo B - Relação dos 276 resumos selecionados do conjunto de teses e dissertações defendidas no Brasil, no período de 2013 a 2017, e que mostraram, nos índices de indexação (título, corpo do resumo ou palavras-chave), algum tipo de apropriação da temática da alfabetização científica pela pesquisa desenvolvida. 


\section{Natureza, estrutura e organização da dissertação}

O texto apresentado nesta produção refere-se a uma dissertação de mestrado acadêmico resultante da sistematização de uma pesquisa desenvolvida no contexto formativo do Programa de Pós-graduação Interunidades em Ensino de Ciências da Universidade de São Paulo, na área de concentração "Ensino de Química".

O corpo textual da dissertação está dividido em 7 partes, compreendendo este primeiro item e mais outro seis, como segue:

- 2) Contextualização da pesquisa a partir da minha trajetória pessoal e profissional

- 3) Introdução

- 4) Referenciais teóricos

- 5) Metodologia

- 6) Resultados e discussão

- 7) Conclusão

No item 2, a pesquisa é "contextualizada a partir da minha trajetória pessoal e profissional", buscando situar esta produção no percurso de experiências que mais impactaram a minha vida e que foram determinantes para a realização desta pesquisa.

No item 3, "introdução", a temática trabalhada na pesquisa é introduzida e contextualizada a partir de uma breve revisão da literatura, ao mesmo tempo que são sistematizadas as principais perguntas que direcionam este estudo e os objetivos gerais e específicos que expressam as ações desenvolvidas.

No item 4, são sistematizados os "referenciais teóricos" diretamente associados ao tema da dissertação, com o objetivo de detalhar e enfatizar os elementos teóricos que norteiam as análises realizadas na pesquisa, permitindo, ao mesmo tempo, que o leitor tenha acesso a um maior aprofundamento dos aspectos teóricos mais significativos.

No item 5, "Metodologia", são detalhados todos os passos do percurso metodológico trilhados na pesquisa, destacando a pertinência e a limitação de cada ação em relação à tentativa de alcançar os objetivos e metas propostos na pesquisa. 
No item 6, "Resultados e discussão", são apresentados os dados e resultados obtidos, bem como as discussões, análises e argumentações, sempre guiadas pelos objetivos da pesquisa, definidos a priori.

No item 7, é explicitada uma "síntese conclusiva", buscando verificar até que ponto o conjunto de resultados obtidos conseguem responder a questão inicial de pesquisa e aos objetivos traçados, de forma a explicitar as reais contribuições do conhecimento produzido para a compreensão da dinâmica de produção de pesquisas envolvendo a temática da alfabetização científica, indicando, também, algumas lacunas que se mostraram relevantes e que poderiam ser consideradas para a complementação e aprofundamento desse estudo em pesquisas futuras relacionadas ao tema. 


\section{Contextualização da pesquisa a partir da minha trajetória pessoal e profissional}

Neste item, contextualizo a pesquisa desenvolvida a partir da minha trajetória pessoal e profissional, buscando situar esta produção no percurso de experiências que mais impactaram a minha vida e que foram determinantes para a realização desta pesquisa. A sistematização deste item foi pensada como uma forma de explicitar as reais motivações e a relevância pessoal que esta pesquisa possuiu, e ainda possui, para mim, de forma a possibilitar ao leitor a percepção do contexto desta produção para além de um documento oriundo de um rito formal de um processo formativo em nível de pós-graduação, possibilitando que seja reconhecida, de forma mais explícita, a relação autor-obra e todo o contexto humano que cerca esta produção.

Começo minha reflexão e o relato da minha trajetória pessoal e acadêmica, partindo da minha condição de estudante do Ensino Fundamental. Naquela época, lembro-me que frequentava as aulas de reforço, não por precisar de ajuda para entender os conceitos trabalhados na disciplina, mas sim para ajudar a professora com os alunos que tinham mais dificuldade; porém, naquele momento, isso ainda não me parecia se configurar como uma paixão por ensinar.

Algum tempo depois, já como aluno do Ensino Médio, dizia estar desinteressado por lecionar, muito por achar meus professores um pouco loucos, ou até mesmo por nutrir uma certa empatia pelos mesmos, que sofriam para tentar controlar o comportamento de seus alunos e até mesmo para ministrar uma aula. Nessa época, não compreendia o que levava meus professores a contentar-se com uma vida profissional tão desvalorizada e onde se ouvia muita reclamação e pouco elogio.

Naquele momento, almejava fazer um curso que me possibilitasse um enriquecimento certo no futuro, e logo decidi por fazer medicina. Sonhava em ser médico, mais especificamente ortopedista, pois era o que eu achava que me tornaria feliz. Nessa mesma época, muito influenciado pela fala de meu avô, que dizia "O sábio é sábio por compartilhar o conhecimento, o ignorante é ignorante por querer o conhecimento apenas para ele. Compartilhe com o próximo o seu conhecimento", 
comecei a ajudar nos cursos da igreja como catequista de crisma, entretanto, não me parecia um gosto profissional, apenas uma boa ação ou dever como católico.

Dessa forma, compenetrado nesse pensamento em ser médico, e tendo o "copo cheio" sobre a minha profissão do futuro, iniciei minha caminhada em busca da tão sonhada profissão. Fazia 3ํano do Ensino Médio de manhã, aulas complementares à tarde e, no período noturno, cursinho preparatório para o vestibular. Via conteúdos mais aprofundados, mais avançados, e até mesmo alguns conteúdos que, hoje, sei que são previstos nos documentos oficiais, porém geralmente não são abordados em sala de aula.

Minha paixão por lecionar começou a aflorar em meus olhos quando, ao estudar matérias mais avançadas no cursinho pré-vestibular, também aprendia conceitos do ensino médio regular que iria ver somente no fim do ano, e, dessa forma, comecei a ajudar o professor de Química dentro da minha própria sala de aula; afinal, tinha muita motivação para ajudar outros alunos em uma matéria na qual tinha mais facilidade e apreço.

Ao fim desse ano, decidi prestar apenas medicina, mesmo possuindo muita vontade de seguir a área de ensino, já que ainda concebia o ato de ensinar não como uma profissão, mas apenas como uma boa ação, assim como era ajudar na catequese de crisma, conforme já relatado aqui.

No ano seguinte, já formado no Ensino Médio, e fazendo cursinho prévestibular, conheci alguns amigos que, ao longo do ano, tiveram a ideia de fazer um cursinho pré-vestibular solidário, destinado a alunos da rede pública. As aulas eram ministradas aos sábados pela manhã e planejadas com o objetivo de ensinar conceitos mais aprofundados do que aqueles que eram vistos no Ensino Médio público, a fim de se conseguir uma melhor preparação desses alunos para os vestibulares, ampliando a possibilidade de sua inserção no ensino superior público.

Contando com o apoio do dono da escola onde fazíamos o cursinho prévestibular, começamos a ministrar algumas aulas aos sábados, no período da manhã, e lá fui eu para a Química de novo, ensinar a matéria que tinha mais afinidade. No meio do ano, um amigo havia comprado o manual do candidato para fazer a inscrição no vestibular da FUVEST que, naquela época, ainda era feita por meio de uma ficha de inscrição "em papel”, enviada por correio. 
Quando estava próximo de fazer a inscrição na FUVEST, esse meu amigo percebeu que os dias das provas coincidiam com os de outra universidade que era a de sua preferência, fazendo com que ele abrisse mão da FUVEST, oferecendo-me a ficha em branco para que eu me inscrevesse. Foi nesse momento que meu caminho começou a se juntar, de fato, com o da carreira mais nobre que existe e comecei a entender que o enriquecimento que eu queria não era material e sim de conhecimento. No entanto, assim que preenchi a ficha com a carreira de Licenciatura em Química Campus Ribeirão Preto, muitas dúvidas e incertezas começaram a ocupar minha mente, principalmente pelo fato da minha escolha profissional estar direcionada à docência.

Ao saber da minha opção, muito colegas me perguntaram por que não havia escolhido o Bacharelado ao invés da licenciatura, e eu respondia, de forma sincera, que "Havia percebido que gostava e levava jeito para ensinar", porém, ainda estava receoso com a escolha dessa direção para minha vida profissional. Não sei se, nesse momento, estava sendo "picado pela mosca azul"1 da educação, o que sei é que ansiava por uma educação de mais qualidade e que a minha atuação profissional poderia contribuir, de alguma forma, para se chegar a esse objetivo.

O único vestibular que passei naquele ano foi o de Licenciatura em Química, porém me pareceu loucura abandonar anos de amor pela Ortopedia por uma 'paixonite' pela educação, e acabei renunciando à vaga. Então, lá fui eu para mais um ano de cursinho pré-vestibular visando me preparar para o tão sonhado curso de medicina.

Mas na metade daquele ano, parei e olhei o que estava acontecendo em minha volta. "Espere, não é isso que eu quero, não é isso que me alegra, pensei comigo". Percebi que estava fazendo o maior desperdício e a pior decisão da minha vida, pois, de fato, estar na sala de aula era o que me alegrava. Então, no meio do ano, mudei meu foco e prestei novamente o vestibular para concorrer a uma vaga para o curso de Licenciatura em Química da Faculdade de Filosofia, Ciências e Letras de Ribeirão

\footnotetext{
${ }_{1}^{1}$ A expressão "picado pela mosca azul" possui sua origem no poema Mosca Azul, de Machado de Assis, que conta a história de um plebeu que, ao deparar-se com uma curiosa mosca azul, com "asas de ouro e granada", deslumbra-se e passa a sonhar com poder e riquezas, ilusão que acaba comprometendo sua sanidade e seu senso de realidade.
} 
Preto (FFCLRP), pertencente ao Campus da USP da mesma cidade, ingressando, nesse curso, no início do ano de 2010.

Dentre as opções disponíveis, poderia ter escolhido apenas a formação de bacharel como alvo profissional, porém, desde cedo, o grande interesse em lecionar fez com que eu escolhesse um curso que me garantisse atribuições tanto de bacharel como licenciado na área da Química, pois mesmo apaixonado pelo ensino, ainda era muito sensível às pressões sociais de que a escolha profissional era equivocada devido aos baixos salários do professor.

Ao ingressar no referido curso, conheci uma professora que despertou em mim um grande interesse em relação à área da Educação, permitindo-me reconhecer muitos aspectos relacionados à epistemologia dessa área. Logo, esse interesse me fez participar, por alguns meses, do grupo de Pesquisa "Epistemologia do Ensino de Ciências" (EPSEC) coordenado por essa professora, o que permitiu que aquele interesse pela área educacional fosse consolidado, assumindo, como fundo conceitual, as teorias vigotskianas. Porém, os afazeres com a graduação e com outras demandas pessoais impossibilitaram uma participação mais efetiva nesse grupo de pesquisa, o que resultou no meu afastamento do mesmo.

Paralelamente, comecei a participar como voluntário na Olimpíada Regional de Química e do Projeto de extensão "DQ de portas abertas", ambos coordenados pelo Centro de Estudos Integrados em Química (CEIQ) do Departamento de Química da FFCLRP/USP. Passei, durante 3 anos, voluntariando simultaneamente em ambos os projetos, o que me permitiu aprofundar ainda mais meu conhecimento pela área educacional, possibilitando-me, ainda, acompanhar a vivência dos licenciados na escola, onde tive os primeiros contatos dentro da graduação com o lecionar específico em química.

Após esse tempo, fui convidado a participar do grupo PIBID Química USP-RP, no qual a imersão na realidade escolar tornou-se ainda maior, possibilitando o meu primeiro contato com referenciais teóricos relacionados à Teoria da Atividade, proposta por Alexei Leontiev², o que possibilitou agir de forma mais efetiva e propositiva junto à escola, ampliando a minha formação para além das restritas

\footnotetext{
2 Alexei Leontiev (1904-1979) foi um psicólogo russo, fundador da Faculdade de Psicologia de Moscou e um dos fundadores da psicologia sócio-histórica. Responsável pela conceituação do Efeito Lobo e da Teoria da Atividade.
} 
observações do universo escolar que fazia durante o Estágio Curricular Supervisionado.

Ao completar 2 anos no grupo, fui conhecer novos grupos de pesquisa da área de Educação. Nesse processo, acabei conhecendo, mais a fundo, a pesquisa desenvolvida pelo professor Mauricio dos Santos Matos, professor associado da área de Ensino de Química do Departamento de Educação, Informação e Comunicação da FFCLRP/USP. A princípio, fiquei interessado mais especificamente pelos projetos de pesquisa relacionados à temática da Educação Ambiental. Todavia, ao descobrir a possibilidade de iniciar uma pesquisa envolvendo a temática "alfabetização científica", optei por iniciar a minha trajetória neste grupo por meio de uma pesquisa vinculada a esse assunto e que constituiu a base dos estudos realizados em nível de iniciação científica e sistematizados em um documento no formato de um texto monográfico.

A escolha da temática teve uma influência direta dos anos estagiados como Iniciação à Docência e PIBID, assim como dos referenciais teóricos dos projetos de extensão e, sobretudo, das disciplinas de Metodologia de Ensino de Ciências que cursei e que, mais tarde, acabei também atuando como monitor, possibilitando um aprofundamento ainda maior sobre essa temática.

O contato com a temática da alfabetização científica me influenciou tanto no âmbito prático quanto no âmbito teórico da minha formação, contribuindo, de forma decisiva, para que eu pudesse compreender o processo de ensino e aprendizagem como algo contínuo que perdura desde o nascimento até a nossa morte, persuadindome e inspirando-me a aprofundar meus estudos sobre essa temática.

O contato com a alfabetização científica, juntamente com seus referenciais, foi determinante para as escolhas que fiz durante a minha trajetória acadêmica, ampliando um ideal genérico que possuía, associado à educação, para uma busca mais objetiva, resultando na sistematização de uma pesquisa em ensino de ciências por meio de uma monografia de conclusão de curso, orientada pelo Prof. Dr. Mauricio dos Santos Matos.

O início do texto monográfico rendeu um resumo estendido que apresentei no ENEQ 2016, porém o mesmo não refletiu completamente todo o conjunto de aspectos estudados e sistematizados na monografia, já que buscava relacionar alguns indicadores de alfabetização científica com as chaves de conhecimento de Vigotski, 
aspecto não contemplado na monografia devido necessitar de estudos mais aprofundados, o que era incompatível com uma monografia de conclusão de curso.

A monografia e a publicação de um trabalho completo num evento de grande relevância na área de Ensino de Química fizeram eu ficar ainda mais convencido sobre seguir a área acadêmica, onde, de fato, poderia contribuir, de alguma maneira, para a melhoria da qualidade da educação e, ao mesmo tempo, possibilitaria que eu exercesse a função de professor.

Ao fim do último ano, vários fatos contribuíram para minha escolha em fazer o Mestrado em Ensino de Ciências; de um lado, a apresentação da monografia e trabalho completo no ENEQ 2016; de outro, as duas monitorias na área do ensino de ciências, nas quais fui monitor voluntário.

A monitoria na disciplina "Didática das Ciências" foi realizada no primeiro semestre de 2016 e me possibilitou ter uma visão melhor da organização e construção da disciplina, assim como uma visão mais abrangente do ponto de vista acadêmico dela. Já a monitoria na disciplina "Atividades Integradas de Estágio", realizada no segundo semestre de 2016, além da visão de estruturação da disciplina, trouxe-me uma maior autonomia dentro da minha linha de pesquisa, na qual eu já havia defendido minha monografia e, assim, já possuía maior apropriação teórica e familiaridade com o tema, o que me possibilitou contribuir, de fato, para a formação dos licenciados em Química que cursaram a disciplina.

Foi dentro desse contexto que o ingresso no Programa de Pós-graduação Interunidades em Ensino de Ciências da USP, no início do ano de 2017, fez com que eu alimentasse a expectativa de contribuir ainda mais para a formação de novos professores e aprimorar minha competência didática, nutrido agora de um embasamento teórico recebido nas disciplinas e com as experiências vivenciadas durante a pós-graduação.

No decorrer do curso de Pós-graduação, pude vivenciar momentos que superaram, em muito, minhas expectativas sobre o curso. Logo no primeiro semestre, pude aprender como estruturar uma pesquisa, mostrando como podemos introduzir um texto a um leitor e utilizar metodologias e instrumentos de pesquisa, sempre com um coração generoso e desejoso de passar ao próximo toda uma vida de aprendizado. 
Concomitantemente, pude participar de palestras, dos mais variados temas, que contribuíram muito para qualificar o meu modo de pensar em relação à minha pesquisa e em relação a outros temas educacionais, ampliando ainda mais a minha visão sobre a temática da pesquisa que desenvolvia, o que me fez passar a ver a alfabetização científica não mais como o único e exclusivo ponto de partida para um ensino de ciência eficaz.

Também pude cursar algumas disciplinas que forneceram importantes contribuições à minha formação na área de educação, tais como: "Neuropsicologia e Educação"; "Abordagem histórico-crítica da Docência no Ensino Superior; Ensino, Aprendizagem e Cultura Didática: Complexidade Escolar e Análise Multilógica.

As disciplinas específicas da área de concentração também se mostraram válidas em sua diversidade de abordagem e aplicações no movimento de alfabetizar cientificamente o aluno e, assim, propiciar uma imersão na cultura e no contexto científico. Numa das disciplinas cursadas, pude avançar a fronteira entre o nível simbólico e o nível submicroscópico da matéria por meio do uso da computação e programas de realidade virtual. Em outra disciplina, a relevância se deu pela abordagem ampla em áreas como saúde, ciências agrárias e contexto social, mostrando a importância de técnicas de eletroquímica para a contextualização e produção da Química como Ciência.

É nesse contexto formativo que a minha trajetória pessoal e profissional foi sendo configurada, direcionando-me para a pesquisa que sistematizo nesta dissertação e que representa mais um passo nesse caminho de construção da minha identidade, edificando novos alicerces em minha formação. 


\section{Introdução}

Neste item, o tema principal trabalhado na pesquisa é introduzido e contextualizado a partir de uma breve revisão bibliográfica dos estudos de Estado da Arte e Estado do Conhecimento relacionados à temática de alfabetização científica, ao mesmo tempo que são sistematizadas as principais perguntas que direcionam esta investigação, buscando explicitar tanto as questões mais gerais até as mais específicas que sinalizam o recorte assumido em nosso estudo. Também são explicitados os objetivos gerais e específicos que expressam as ações desenvolvidas na pesquisa e que direcionaram os passos e os métodos escolhidos durante o processo investigativo, com a finalidade de procurar possíveis respostas aos questionamentos formulados.

\subsection{Uma breve revisão bibliográfica dos Estudos de Estado da Arte e Estado do Conhecimento relacionados à temática de alfabetização científica no Brasil}

No campo da pesquisa educacional, no Brasil, nos últimos 30 anos, diversos trabalhos buscaram recuperar, sistematizar e descrever as informações disponíveis na produção acadêmica, em período especificado e em uma área determinada, como é o caso, por exemplo, de: Livro didático no Brasil (FREITAG, MOTTA \& COSTA, 1987); Alfabetização (SOARES \& MACIEL, 2000); ensino de Física (MEGID NETO, 1990; RESENDE, OSTERMANN e FERRAZ, 2009); livro didático de Ciências no Brasil (FRACALANZA, 1993; FRACALANZA \& MEGID NETO, 2006); educação Matemática (FIORENTINI, 1994); ensino de Ciências no nível fundamental (MEGID NETO, 1999); Ciências Físicas e Biológicas (LEMGRUBER, 1999); Educação de Jovens e Adultos (HADDAD, 2002); formação de professores e de profissionais da Educação (ANDRÉ, 2002; BRZEZINSKI \& GARRIDO, 2014), ensino de Ciência para estudantes surdos (SANTANA e SOFIATO, 2018), Perspectiva CTS/CTSA no Ensino de Química (LOCATELLI, ZOCH e AMARAL, 2015), ensino de Biologia (SLONGO, 2004; TEIXEIRA \& MEGID NETO, 2007) etc. 
Todos os trabalhos, de uma ou de outra forma, se debruçam sobre a produção acadêmica, comparam entre si diversas pesquisas (em sua quase totalidade constituída por dissertações e teses), e os descrevem criticamente procurando sinalizar o que se sabe sobre diversos aspectos da temática considerada. Em especial, analisam os objetos de investigação, os problemas focalizados, os procedimentos de investigação realizados, os principais resultados e lacunas ainda existentes. Também, usualmente, se autodenominam de pesquisa do "Estado da Arte " ou "Estado do Conhecimento".

Tais estudos são reconhecidos por

[...] realizarem uma metodologia de caráter inventariante e descritivo da produção acadêmica e científica sobre o tema que busca investigar, à luz de categorias e facetas que se caracterizam enquanto tais em cada trabalho e no conjunto deles, sob os quais o fenômeno passa a ser analisado [...] (FERREIRA, 2002, 258).

Apesar de muitas produções da literatura nacional e internacional apropriaremse das denominações "Estado da Arte " e "Estado do Conhecimento" como sinônimos, definindo-as conforme a citação acima, também utilizada por (MOROSINI, 2014, 2015), nos últimos anos, alguns autores vem buscando diferenciá-las, associando a expressão "Estado do Conhecimento" a estudos de caráter mais delimitado e restrito em termos do corpo documental de produções científicas, como também em termos do objeto de pesquisa, caracterizando-se, segundo Romanowski e Ens (2006), como o estudo que aborda apenas um setor das publicações sobre o tema estudado.

Considerando essa compreensão, compreendemos que a presente pesquisa pode ser classificada como uma pesquisa de Estado do Conhecimento, devido ao fato dessa pesquisa contemplar apenas um tipo de corpus documental "teses e dissertações", também restritas a um curto período, abrindo mão de outros conjuntos de produções científicas relevantes e de importância para a área de Ensino de ciência e para a comunicação de informações científicas acerca da temática da alfabetização científica.

Em relação à temática da $A C$, é verificada, na literatura nacional, a intenção de caracterizar a produção sobre AC por meio de pesquisas do tipo Estado da Arte , 
principalmente focalizando a área de Ensino de Ciências. Por exemplo, Matheus e Maciel (2019), numa pesquisa sobre AC, restrita às produções de mestrado de Programas de Pós-graduação em ensino de Ciências, no período de 2013 a 2017 , observaram que a escolha das metodologias nas pesquisas sobre AC apoiaram-se nos objetivos contidos nas dissertações e seus autores buscaram um entendimento mais aprofundado sobre o processo de Alfabetização Científica.

Analisando as produções acadêmicas no período de 2005 a 2015, com foco nos Anos Iniciais do Ensino Fundamental, Santana e Franzolin (2016) observaram um forte interesse dos pesquisadores em temas que estudam a relação entre as interações discursivas e a alfabetização científica.

Viechenneski, Lorenzetti e Carletto (2015), a partir da análise dos Encontros Nacionais de Pesquisa em Educação em Ciências (ENPECs) entre os anos de 1997 a 2013, analisou artigos envolvendo a AC nos anos iniciais do Ensino Fundamental, focalizando a caracterização dos objetivos, problemas, metodologias e as contribuições para a Educação em Ciências.

Esse conjunto e outros presentes na literatura nacional ilustram bem a necessidade de se compreender a produção científica e acadêmica acerca da alfabetização científica em diferentes áreas, legitimando esse referencial como um referencial de grande interesse, principalmente para as pesquisas em Ensino de Ciências.

\subsection{Problematização}

O enorme crescimento no número de cursos de Pós-graduação stricto sensu no Brasil, nos últimos 10 anos, trouxe, como consequência direta, o aumento da produção acadêmica, incorporando, muitas vezes, mudanças no perfil de pesquisas relacionadas a uma dada área do conhecimento, ou mesmo em relação a alguma temática específica, necessitando que, de tempos em tempos, essa produção possa ser revisitada e analisada, a fim de possibilitar a sua caracterização e reconhecimento de possíveis mudanças de suas características na dinâmica dessa produção, bem 
como permitir, consequentemente, a verificação de possíveis tendências ao longo dos anos.

Esse referido crescimento da pós-graduação stricto sensu é identificado em Cirani, Campanário e Silva (2015), que apontam que, embora insuficiente,

[...] a experiência brasileira de geração de conhecimento na pós-graduação senso estrito nos últimos dez anos é uma das realizações relativamente bemsucedidas no conjunto do sistema de ensino existente, pois vem formando cursos e profissionais em praticamente todos os setores do conhecimento e regiões do país. No entanto, existem poucas análises e estudos sobre quanto, onde e quando o ensino da pós-graduação senso estrito vem crescendo ao longo do tempo [...] (p. 165)

Nesse contexto, optamos, nesta pesquisa de mestrado, focalizar o nosso estudo na análise e caracterização do conjunto de teses e dissertações produzidas no Brasil, no período de 2013 a 2017. No entanto, devido ao conjunto extenso de produção acadêmica na área educacional e na área de ensino de ciências, a nossa pesquisa foi delimitada, de forma a tornar-se exequível, considerando o pouco tempo envolvido numa pesquisa em nível de mestrado, necessitando uma maior delimitação do nosso corpus documental de análise e um direcionamento e aprofundamento do estudo em relação a alguma temática atual e relevante da área de Ensino de Ciências.

Assim, como ponto de partida para a organização e realização desta pesquisa, optamos por aprofundar os estudos sobre a "alfabetização científica" (AC), temática de grande relevância e importância para a área educacional brasileira e internacional, já estudada e considerada em outro estudo por mim realizado (RODRIGES, 2016), permitindo o meu aprofundamento em relação a essa temática, agora sob o foco da presença da AC na produção acadêmica do conjunto de teses e dissertações produzidas no Brasil no período de 2013 a 2017.

A ideia de direcionar a pesquisa na perspectiva de uma pesquisa de Estado do Conhecimento, sendo este um recorte mais específico de pesquisas do tipo "Estado da Arte ", aparece como consequência natural do percurso do grupo de Pesquisa "Ciência, Comportamento e Ambiente" (CCA), do qual faço parte e que, nos últimos anos, desenvolveu um trabalho contínuo de cooperação com grupos do Instituto de Biociências da Unesp de Rio Claro, da Universidade Federal de São Carlos e da 
Faculdade de Educação da Unicamp, com especial destaque para o grupo "Formar Ciências", da Unicamp, do nosso saudoso professor Hilário Fracalanza e dos Professores Ivan Amorosino do Amaral e Prof. Jorge Megid Neto, que vem contribuindo muito com o Ensino de Ciências por meio da sistematização de pesquisas de Estado da Arte nessa área do conhecimento, como também por meio da organização e sistematização da produção científica na área, o que permitiu uma compreensão mais efetiva dessa produção, principalmente em relação às suas características e tendências observadas ao longo do tempo.

Para assumirmos um recorte que possibilitasse um estudo do tipo "Estado do Conhecimento" dentro do tempo de um mestrado acadêmico, resolvemos estabelecer, como recorte de nossa pesquisa, a análise da produção restrita aos últimos 5 anos. No entanto, até a data de análise do corpus documental da pesquisa, os dados sobre a produção acadêmica na CAPES possuíam consolidação e validação até o ano de 2017, fazendo com que fosse definido o período de 2013 a 2017 como o nosso período de análise.

Considerando essas delimitações, a pesquisa proposta busca responder a seguinte questão de pesquisa: Quais as características e tendências observadas no conjunto de teses e dissertações defendidas no Brasil, no período de 2013 a 2017, envolvendo a temática da "alfabetização científica"?

A partir desse questionamento mais geral, delimitamos a nossa questão de pesquisa em termos dos eixos estruturantes da alfabetização científica, resultando na seguinte pergunta: Quais eixos estruturantes estão mais evidenciados nas pesquisas que se apropriam da temática da alfabetização científica $(A C)$ publicadas no período de 2013 a 2017, e como se dá a apropriação desses eixos por essas pesquisas?

Esse questionamento mostra uma maior delimitação da pesquisa, focalizando a nossa análise a partir dos eixos estruturantes da AC, contemplando, também, de forma implícita, uma caracterização mais descritiva e inventariante do contexto ${ }^{3}$ e tipo de produção a partir de descritores mais gerais utilizados pela CAPES para a indexação da produção, comumente utilizados em pesquisas do tipo Estado da Arte

\footnotetext{
${ }^{3}$ A caracterização do contexto de produção refere-se aos indexadores associados à localidade da produção (grande região, estado, instituição de Ensino Superior).
} 
ou Estado do Conhecimento, como também uma caracterização da pesquisa ${ }^{4}$ por meio do uso de descritores associados diretamente à particularidade da pesquisa.

\subsection{Objetivos}

A partir da questão de pesquisa formulada no item 3.2, é proposto como objetivo geral:

- Caracterizar, a partir do uso de descritores definidos a posteriori e outros consolidados na literatura ${ }^{5}$, o conjunto de teses e dissertações defendidas no Brasil, no período de 2013 a 2017, que mostraram algum tipo de apropriação da temática da AC, buscando reconhecer possíveis tendências, movimentos ${ }^{6}$ e características específicas ${ }^{7}$ dessa produção, principalmente em relação à apropriação dos eixos estruturantes de $A C^{8}$.

A partir desse objetivo geral, a pesquisa foi organizada de forma a contemplar ações mais diretivas a partir dos seguintes objetivos específicos:

- Caracterizar, no período analisado, a representatividade da presença da expressão "alfabetização científica" em comparação com a as expressões "letramento científico" e "enculturação científica" no conjunto de resumos de teses e dissertações no período analisado.

- Definir, no período analisado, o conjunto de teses e dissertações que mostraram alguma apropriação da temática da AC.

\footnotetext{
${ }^{4}$ A caracterização da pesquisa refere-se a categorias de descritores associados à particularidade da pesquisa explicitada no corpo textual dos resumos.

5 Para a caracterização de pesquisas acadêmicas em pesquisas do tipo "Estado da Arte" ou "Estado do Conhecimento", já explicitados na própria plataforma Sucupira da CAPES.

${ }^{6}$ Esses movimentos se referem a mudanças observadas nas características da produção no período analisado, mas que não se constituem necessariamente como uma tendência.

7 Considera-se como característica específica toda característica observada no conjunto analisado e que não esteja presente no conjunto maior e mais inclusivo no qual o conjunto analisado encontra-se inserido.

${ }^{8}$ Os eixos estruturantes de AC são: conhecimento científico, natureza da ciência, contextualização.
} 
- Caracterizar, no período analisado, as produções acadêmicas em AC em termos do contexto da produção ${ }^{9}$ e do tipo de produção ${ }^{10}$

- Caracterizar, no período analisado, as produções acadêmicas em AC em termos dos aspectos gerais ${ }^{11}$ da pesquisa

- Caracterizar, no período analisado, a apropriação de cada um dos eixos estruturantes de AC na produção acadêmica em AC.

A partir desse conjunto de ações, a pesquisa busca, como meta, contribuir para uma maior compreensão da produção nacional de teses e dissertações no período analisado que se apropriaram da temática da alfabetização científica, consciente dos limites $^{12}$ inerentes ao recorte temporal de 5 anos e à opção de análise da produção acadêmica restrita aos resumos dessa produção.

\footnotetext{
${ }^{9}$ A caracterização do contexto de produção foi feita por meio dos seguintes descritores definidos pela CAPES na indexação das teses e dissertações: grandes regiões, estado, instituição de ensino superior.
10 A caracterização do tipo de produção foi feita por meio dos seguintes descritores definidos pela CAPES na indexação das teses e dissertações: teses (doutorado) ou dissertações (mestrado acadêmico ou profissional); grande área do conhecimento a que se refere a produção e área do conhecimento a que se refere o Programa de Pós-Graduação associado à produção.

11 Os aspectos gerais da pesquisa caracterizados foram identificados a posteriori, durante a análise dos resumos e detalhados na metodologia.

12 Essas limitações se referem ao fato dos resumos nem sempre apresentarem uma estrutura que contemple aspectos básicos da pesquisa e, também, por conterem um texto muito restrito, dificultando o reconhecimento de elementos que possam caracterizar, de forma mais ampla e completa, a pesquisa desenvolvida. Além dessas limitações intrínsecas, quando se compara resumos de produções acadêmicas de diferentes áreas do conhecimento, também é possível haver muitas diferenças entre os resumos em termos de sua estrutura devido às particularidades de cada área. Outro fator não menos relevante a ser considerado é o formato multipaper (COSTA, 2014; NASSI-CALÒ, 2013), cada vez mais presente nos Programas de Pós-Graduação Brasileiros e que amplia, ainda mais, a fragilidade estrutural e informativa dos resumos, pelo fato deste formato estruturar o trabalho acadêmico a partir de uma combinação de várias artigos independentes, com problematizações, objetivos e metodologias próprias, nem sempre estabelecendo relações diretas, orgânicas e sistemáticas com outros artigos que compõem o trabalho acadêmico estruturado nesse formato, fazendo com que o resumo nem sempre explicite uma síntese que corresponda adequadamente a pesquisa desenvolvida. Essa discussão sobre os diferentes formatos foi enfatizada no Editorial da Revista Nature (THE..., 2016).
} 


\section{Referencial Teórico}

Neste item, faremos a sistematização do referencial teórico, considerando a historicidade do conceito de alfabetização científica (AC), bem como a caracterização de cada um dos eixos estruturantes da AC (natureza da ciência, contextualização e conhecimento científico), compreendendo que cada eixo possui relação direta com os demais, não devendo ser compreendidos como entes separados e distantes um do outro. Assim, a opção de assumirmos a explicitação de cada um dos eixos, de forma individualizada, está associada à necessidade de compatibilizarmos nosso estudo à sistematização proposta na literatura ${ }^{13}$, ao mesmo tempo que possibilita um maior aprofundamento sobre cada um dos eixos.

\subsection{Alfabetização Científica}

Falar sobre alfabetização política, alfabetização tecnológica, alfabetização científica etc., resulta na estruturação de outros conceitos que incorporam vários outros elementos que caracterizam cada uma das áreas do conhecimento, ampliandose para além de suas linguagens específicas.

Assim, o termo "alfabetização científica" não especifica uma tipologia de alfabetização, nem tampouco possui, no termo "científica", apenas um elemento que adjetiva ou qualifica a alfabetização, e sim apresenta-se como um conceito mais amplo e que possui a alfabetização como uma de suas referências.

De certa forma, considerando as ações constantes dos governos estaduais e federal, nos últimos anos, em colocar a aprendizagem da leitura e da escrita como foco exclusivo da educação, em detrimento de uma formação científica, também necessária para a formação do cidadão, o uso da terminologia "alfabetização científica" acaba por se mostrar estratégico politicamente, já que associa a formação

13 A discriminação e caracterização de cada eixo da alfabetização científica foi proposta por SASSERON e CARVALHO (2008). 
científica à alfabetização, não podendo, portanto, ser colocada em segundo plano ou mesmo desconsiderada das políticas públicas em educação.

No entanto, a Alfabetização Científica não deve ser assumida de forma ingênua e equivocada, associando-a e restringindo-a ao saber ler e escrever "cientificamente", devendo ser concebida em sua relação com o desenvolvimento crítico dos indivíduos sobre o contexto, as tecnologias e a sociedade onde se situam e se integram, de forma a se perceberem incluídos no universo científico, conforme aponta Sasseron e Carvalho (2008).

Considerando as contribuições da alfabetização científica para a leitura e a escrita, Lorenzetti e Delizoicov (2001) defendem.

[...] a premissa de que a alfabetização científica pode e deve ser desenvolvida desde o início do processo de escolarização, mesmo antes que a criança saiba ler e escrever. Nesta perspectiva, o ensino de ciências pode se constituir num potente aliado para o desenvolvimento da leitura e da escrita, uma vez que contribuí para atribuir sentidos e significados às palavras e aos discursos. (LORENZETTI \& DELIZOICOV, 2001, p. 57).

Essa valorização do saber para além das ações de ler e escrever tem sido o foco de alguns autores que salientam a importância do saber ler e escrever para o indivíduo alfabetizado cientificamente, compreendendo que sem a competência de leitura e da escrita não seria possível o contato efetivo do estudante com a ciência, ao mesmo tempo que apenas a competência da leitura e da escrita não pode ser compreendida como a totalidade do processo de alfabetização científica, o que o restringiria apenas à mera apropriação de códigos e linguagens da ciência, sem o compromisso de desenvolvimento de outras competências desejáveis que se remetem às relações entre o indivíduo e o contexto social que o cerca e a sua efetiva inserção na cultura científica.

Para Norris e Philips (2003, apud SASSERON e CARVALHO, 2011), a competência de leitura e escrita mostra-se determinante para processos formativos e ações essenciais promotoras da alfabetização científica, tais como: 
(a) da gravação e apresentação e re-apresentação de dados; (b) da decodificação e preservação da ciência aceita para outros cientistas; (c) da revisão de ideias por cientistas em qualquer lugar do mundo; (d) da reexaminação crítica das ideias quando elas são publicadas; (e) da futura conexão das ideias que foram desenvolvidas anteriormente; (f) da comunicação das ideias científicas entre aqueles que nunca se encontraram e mesmo entre aqueles que não viveram na mesma época; (g) da decodificação de posições variantes; e (h) do enfoque da atenção combinada no conjunto das ideias fixadas para o propósito da interpretação, predição, explicação ou teste. (p.67)

Hurd (1998) descreve a preocupação de desenvolver uma alfabetização científica por meio da problematização, assumindo um compromisso com 0 desenvolvimento da ciência na sociedade e pela sociedade. Assim, estabelece a possibilidade de se trabalhar a ciência em sua relação com a sociedade na perspectiva de co-dependência entre o desenvolvimento da ciência e o desenvolvimento da sociedade, bem como as suas relações com a tecnologia.

No entanto, a despeito da grande aceitação e reconhecimento atual da importância dessa temática para o ensino de ciências, houve e ainda há algumas resistências no meio acadêmico, sendo, por vezes, tema de controvérsia no campo científico, assumido, muitas vezes, como algo utópico (SHAMOS, 1995) ou mesmo tratado como "algo semelhante a um romance" ou, equivocadamente, restrito apenas ao currículo escolar. Por exemplo, Deboer (2000) já mostrava a dificuldade de alguns pesquisadores de educação em ciência em diferenciar educação científica e alfabetização científica, por entenderem a Alfabetização como um slogan para mudanças no modo de se ensinar ciência, o que, de certa forma, acontece realmente com muitos termos e linguagens apresentadas ao meio acadêmico da área educacional, que, por meio de um "apagamento" histórico, apresenta aspectos antigos com vestimenta e status de moderno. No entanto, como aponta Gimeno Sacristán et al. (2011),

Moderno não é aquilo que é recente ou novidade, ou aquilo que fazemos com que assim pareça, mas sim o que perdura e o que transforma a vida e a realidade. Não se muda o mundo com o objetivo de evoluí-lo sem considerar como ele é, quem está nele e como vivem seus habitantes. Causa certa perplexidade a facilidade com que se põem em circulação linguagens e 
metáforas que nos levam a denominar de forma aparentemente nova aquilo que, até então, reconhecíamos de outra forma. A mesma sensação nos produz o entusiasmo com o qual, aparentemente, nos integramos a um novo universo de formas de falar sobre preocupações que aparentam ser novas porque, anteriormente, eram chamadas de outra maneira. As novas linguagens talvez sejam necessárias para abordar novas realidades, para descobrir algo verdadeiramente novo nelas; no entanto, frequentemente, são a expressão da capacidade que os poderes e as burocracias têm para padronizar as maneiras de ver e de pensar a realidade em função de determinados interesses. São, em outros casos, criações de especialistas em busca de fórmulas para expressar suas concepções e propostas com mais precisão, mas também com a finalidade de manter seus privilégios. Essa volatilidade da vigência das linguagens deveria ser um sério motivo de reflexão, por muitas razões. (p. 7)

É nesse contexto, que, atualmente, o mundo acadêmico expressa sua compreensão sobre o conceito de Alfabetização Científica, legitimando algumas expressões e linguagens como "letramento científico", "enculturação científica", além da própria expressão "alfabetização científica" (AC), utilizadas, muitas vezes, como sinônimos, e em outras situações, como conceitos distintos de uso preferencial por alguns autores, que justificam seu uso geralmente por creditar a maior precisão de uma linguagem em relação a outra em relação a aspectos valorativos que permeiam a base epistemológica da Educação em Ciências.

A amplificação do significado de Alfabetização Científica passa, então, pelo caráter polissêmico das expressões em termos da forma como são apropriadas, intencionalmente ou não, muitas vezes, até motivado pela dificuldade de tradução de literaturas internacionais que versam sobre a temática.

Para além das linguagens, autores como Sasseron e Carvalho (2008) descrevem o processo de alfabetização científica a partir de três eixos estruturantes (conhecimento científico, contextualização e natureza da Ciência), detalhados no item 4.2 .

Para além desses eixos estruturantes, Sasseron e Carvalho (2008) também sistematizam alguns descritores mais focalizados, em forma de indicadores, com intuito de expressar elementos formativos que possam permitir o reconhecimento e acompanhamento do processo de alfabetização científica, podendo ser caracterizados como "competências próprias das ciências e do fazer científico" (SASSERON \& 
CARVALHO, 2008, p. 338), propondo um viés mais direcionado e específico associado ao processo, facilitando a sua identificação e acompanhamento.

Diferentemente, contribuições anteriores de Shen (1975) e Bybee (1995) assumem posturas mais conceituais e apresentam uma abordagem mais ampla sobre o tema. Shen (1975) apresenta uma proposta que ultrapassa o ambiente escolar como um processo em construção diária, relacionados com a objetivação formativa cidadã, necessidade e contextualização no desenvolvimento de habilidades e atitudes, apropriada pela utilização do conhecimento científico. $\mathrm{O}$ autor propõe três entendimentos sobre alfabetização científica, tendo como referência, além dos objetivos, o público, o formato e como é propagada. São eles: Alfabetização Científica "prática", "cívica" e "cultural".

A "alfabetização científica prática" refere-se à utilização de um conhecimento científico mínimo, com o qual o indivíduo pode tomar decisões críticas sobre as questões mais básicas em seu dia-a-dia, devendo, esse entendimento, ser de acesso de qualquer indivíduo.

O segundo entendimento, "alfabetização científica cívica", depende de um contato maior com o conhecimento científico, sendo que o mesmo conhecimento direciona o indivíduo a tomar decisões críticas não apenas sobre seus hábitos do diaa-dia, mas também sobre assuntos relativos à sociedade onde vive e, assim, propiciar discussões mais democráticas em cima da sociedade que se constrói.

O último entendimento, "alfabetização científica cultural", baseia-se na relação entre a ciência e a humanidade, configurando-se como o estágio mais avançado da alfabetização científica, no qual os conhecimentos científicos não apenas se relacionam com o dia-a-dia das pessoas ou com as discussões da sociedade atual, mas, sobretudo, promovem uma reflexão contínua de como a ciência se desenvolveu em conjunto com a história da sociedade, e como poderá influir no contínuo processo de desenvolvimento futuro da sociedade. Essa perspectiva concebe a alfabetização científica como algo a ser apreciada por um número mínimo de indivíduos, que não fazem parte do meio acadêmico, como uma forma de busca por um saber mais específico sobre determinado assunto científico, podendo até ser comparada com a apreciação da arte por um artista.

Assumindo Bybee (1995) como pano de fundo, a discussão proposta se dá em um ambiente escolar, tomando como base a incorporação gradual de conhecimento 
científico. O autor apresenta 3 dimensões de Alfabetização Científica; "funcional", "conceitual e processual" e "multidimensional".

O entendimento da dimensão da "alfabetização científica funcional" se dá como uma dimensão mais tecnicista, com a aquisição de vocabulário apropriado ao conhecimento científico. Já na "alfabetização científica conceitual e processual”, o indivíduo se apropria dos conceitos e confere significação para além do vocabulário, compreendendo a ciência em seus processos e conceitos.

A última dimensão "alfabetização científica multidimensional" é associada ao indivíduo que já compreende a ciência em seus processos e conceitos, além de apenas aplicá-los, sendo possível, também, explicá-los e prevê-los num contexto que vai além do cotidiano.

Entendemos, assim, a importância de se ampliar o entendimento público da Ciência para além do seu caráter técnico e intelectual, incorporando, também, a cultura científica ampliada, que se mostra cada vez mais essencial para o mundo tecnológico e científico no qual vivemos.

Para o desenvolvimento dessa pesquisa assumiremos uma perspectiva mais ampla da alfabetização científica, sem um olhar direcionado a definições fechadas, mas assumindo a sua identidade associada a composição dos três eixos estruturantes detalhados no item 4.2, mesmo consciente da existência de uma certa fragilidade e imprecisão na caracterização em separado de tais eixos, principalmente nas relações entre natureza da ciência e contextualização, conforme discutido no item 4.2.

\subsection{Eixos estruturantes da alfabetização científica}

Ao aprofundarmos no conceito de Alfabetização Científica (AC) delineado por Sasseron e Carvalho (2008), entendemos que os eixos estruturantes, propostos pelas autoras, são muito úteis para a caracterização da apropriação dessa temática em pesquisas científicas devido ao fato desses eixos serem facilmente identificados nas pesquisas desenvolvidas, permitindo reconhecer a forma de apropriação da $A C$ a partir de seus eixos estruturantes: conhecimento científico, natureza da Ciência, contextualização. 
Esses eixos, como as próprias autoras relatam, “(..)surgiram da análise de referenciais da área de Ensino de Ciências que apresentavam ideias e habilidades a serem desenvolvidas com o intuito de que a Alfabetização Científica pudesse estar em processo.(...)" Assim, o intuito de definir esses eixos está na demarcação de linhas orientadoras para trabalhar o ensino de ciências e transitar entre características já fixadas pelo currículo dessas ciências e em "ações em esferas extraescolares". Talvez, o propósito dessa divisão entre os eixos, no intuito apresentado pelas autoras, associada à demarcação de linhas orientadoras, possa ser responsável pelos limites e inconsistências impostos por essa separação, principalmente em relação à História da Ciência, que pode se referir tanto à natureza da Ciência quanto à contextualização.

Nos itens sistematizados a seguir, detalhamos cada um dos três eixos estruturantes de AC, explicitando alguns aspectos teóricos considerados na análise dos resumos da produção acadêmica realizada em nossa pesquisa.

\subsubsection{Conhecimento Científico}

Neste item, o conhecimento científico é aprofundado, buscando compreender a partir de suas características e diferenças em relação a outros tipos de conhecimento, bem como em relação à sua identidade como conhecimento escolar transposto didaticamente ou recontextualizado.

\subsubsection{Caracterização e diferenciação em relação a outros tipos de conhecimento}

Segundo Sasseron e Carvalho (2008), o primeiro eixo estruturante da alfabetização científica é o Conhecimento Científico e refere-se à compreensão básica de termos, conhecimentos e conceitos científicos fundamentais e a importância deles reside na necessidade exigida em nossa sociedade de se compreender conceitos-chave como forma de poder entender até mesmo pequenas informações e situações do dia-a-dia. 
Ampliando a nossa discussão sobre o conhecimento científico para uma ideia mais geral associada ao conhecimento, podemos aprofundar ainda mais a nossa compreensão sobre as características desse eixo da alfabetização científica, possibilitando, também, reconhecer elementos que o diferencia dos demais tipos de conhecimento (Quadro 1), definidos como empírico (ou vulgar, cotidiano, cotidiano, senso comum), filosófico, e religioso (ou teológico).

Estrela (2008) esclarece que o conhecimento científico se distingue pelo caráter sistemático, pela utilização consciente e explicitada de um método, objeto permanente de uma meta-análise, individual e coletiva. $O$ trabalho científico consiste numa busca permanente da verdade, através de um conhecimento sempre provisório e conjetural, empiricamente refutável.

Alves (2013), buscando delimitar e fixar a ideia de "mentalidade científica", aponta que a ciência tem seu "método" científico inegável e consolidado que, em momentos de lucidez e razão da humanidade, buscou seu ponto de fixação e caracterização; porém, essa mesma razão e lucidez que a embasa mostra que o conhecimento não deve ser algo inabalável, dando espaço para possível revisão e reflexão do pensamento racional quando necessário.

De fato, a ideia de um método sistematizado, mesmo sujeito à revisão, apresenta-se como uma das características basilares do conhecimento científico, diferenciando-o dos demais, como explicitado no Quadro 1 e que representa uma síntese nossa daquilo que é apresentado na literatura.

Quadro 1 Tipologias do conhecimento

\begin{tabular}{|c|c|c|c|}
\hline $\begin{array}{l}\text { Conhecimento } \\
\text { popular * }\end{array}$ & $\begin{array}{l}\text { Conhecimento } \\
\text { científico }\end{array}$ & $\begin{array}{l}\text { Conhecimento } \\
\text { filosófico }\end{array}$ & $\begin{array}{c}\text { Conhecimento } \\
\text { Religioso** }\end{array}$ \\
\hline $\begin{array}{l}\text { Adquirido por meio da } \\
\text { observação, em experiências } \\
\text { vividas ou transmitidas por } \\
\text { terceiros }\end{array}$ & $\begin{array}{l}\text { Adquirido por meio de } \\
\text { investigação sistemática } \\
\text { e metódica }\end{array}$ & $\begin{array}{lr}\text { Adquirido } & \text { pela } \\
\text { capacidade } & \text { de } \\
\text { reflexão lógica } & \end{array}$ & $\begin{array}{l}\text { Baseado na fé e, } \\
\text { portanto, desprovido } \\
\text { de métodos }\end{array}$ \\
\hline $\begin{array}{l}\text { Apresenta grande utilidade e é } \\
\text { construído sem método } \\
\text { definido e de forma } \\
\text { assistemática. }\end{array}$ & $\begin{array}{l}\text { Estabelecido por } \\
\text { argumentos racionais e } \\
\text { comprovações }\end{array}$ & $\begin{array}{l}\text { É a matriz básica do } \\
\text { conhecimento } \\
\text { científico }\end{array}$ & $\begin{array}{l}\text { Transmitido pelo } \\
\text { conteúdo dos textos } \\
\text { sagrados }\end{array}$ \\
\hline
\end{tabular}




\subsubsection{2 $O$ conhecimento escolar como a verdadeira identidade do conhecimento científico transposto didaticamente ou recontextualizado}

Para além da tipologia do conhecimento, é importante reconhecermos que o conhecimento científico desenvolvido na escola não é o mesmo conhecimento produzido na Ciência, ao mesmo tempo que tem, neste último, uma referência importante. O saber ensinado na escola sofre transformações e o conhecimento científico produzido na ciência é diferente daquele que chega à sala de aula, sendo mais adequado caracterizar esse conhecimento que se ensina na escola como conhecimento escolar (LOPES, 1999) e que possui características e organização próprias, sendo resultado de um processo de transformação do conhecimento, configurando-se como um tipo de conhecimento próprio que se caracteriza por ser uma re(construção) do conhecimento científico.

Para compreendermos esse processo, apresentaremos, de forma sucinta, alguns elementos relacionados ao conceito de transposição didática e da recontextualização, dando destaque aos seus aspectos essenciais.

O conceito de transposição didática foi formulado pelo sociólogo Michel Verret, na década de 1970, e introduzido na didática da matemática por Yves Chevallard, na década seguinte, para, posteriormente, ser utilizado na didática das Ciências (CARVALHO, CLÉMENT, 2007; CARVALHO, 2009).

Chevallard (1991, p.16-17) descreve este processo, considerando como origem do saber apenas a comunidade científica. Para o autor, para que seja possível o ensino de um determinado saber, este deve sofrer certas transformações: o saber, tal como é ensinado (o saber ensinado) é diferente do saber inicialmente designado como aquele que deve ser ensinado (o saber a ensinar), que, por sua vez, é diferente do saber produzido pela comunidade científica (o Saber Sábio).

Conforme esclarece o autor, esses três saberes coexistem num ambiente chamado Noosfera, uma esfera na qual ocorre o encontro de pessoas/instituições ligadas ao sistema educacional e representantes da sociedade, cada qual com seus interesses; ou seja, o centro dos conflitos, negociações e soluções: "a esfera onde se pensa - segundo modalidades talvez muito diferentes- o funcionamento didático" (CHEVALLARD, 1991, p.28). 
Como definição, para Chevallard, o saber designado como Saber Sábio pode ser compreendido como o conhecimento gerado pela comunidade científica por um cientista, ou grupo de cientistas - que, na busca por uma resposta ou solução de um problema, delinearam um raciocínio para, por meio de instrumentos e procedimentos próprios, realizarem as pesquisas que geraram a descoberta. Após a descoberta, este processo é descrito com base nas regras próprias da comunidade científica, de forma impessoal e sistemática, apresentando o novo conhecimento (normalmente por meio de artigos, teses etc.) para difundi-lo nesta comunidade científica e, tomar assim, o status de Saber Sábio.

Já o saber a ensinar é o conhecimento gerado pela comunidade científica reestruturado numa linguagem mais simples que a sua de origem e organizado por meio de livros e manuais de ensino. Nessa reestruturação e organização, o conhecimento é descontextualizado, gerando um saber diferente do original. Esse conhecimento, para chegar aos alunos, sofre mais uma transformação, desta vez para gerar o saber ensinado, pois necessita de uma contextualização para o ambiente em que ocorrerá o ensino. Nesta contextualização para o ambiente, o professor aparece como um protagonista, que realizará a transformação do saber a ensinar (determinado normalmente por um cronograma) para o saber ensinado, que é influenciado tanto pelas características pessoais do educador, quanto pelo ambiente no qual ocorrerá o ensino e as características intrínsecas dos educandos.

Essas transformações do Saber Sábio até o saber ensinado, que Chevallard (1991, p.22) conceitua como Transposição Didática, pode ser verificada por meio do confronto dos termos que demonstra a distância que os separa. Para o autor (p.45), esse sistema do conteúdo como um objeto de saber (Saber Sábio) designado como objeto a ensinar (saber a ensinar), que sofre um conjunto de transformações adaptativas para torná-lo apto para ocupar um lugar entre os objetos de ensino (saber ensinado), deve respeitar duas condições: 1) o saber ensinado deve estar próximo do Saber Sábio, de forma que não perca sua legitimidade; 2) o saber ensinado deve estar atualizado, de forma que não seja um saber "banalizado" (p.30).

A transposição didática também é atualmente apropriada pelo Ensino de Ciências a partir do modelo KVP proposto por Clément (2010) que propõe o estudo da transposição didática, principalmente no aspecto das relações entre o conhecimento, os valores e as práticas sociais. Nesta interação, o conhecimento "K" é considerado como a informação proveniente da comunidade científica; no sistema de valores "V" 
estão as opiniões, crenças e ideologias; e as práticas sociais "P" estão relacionadas às ações dos atores do sistema educacional (as práticas de ensino dos professores e as práticas dos autores e editores de manuais escolares).

Diferentemente do modelo de Chevallard, o modelo KVP de transposição didática dá mais força e destaque ao papel das práticas sociais como um referente importante para a definição, escolha e transformação dos conceitos trabalhados em sala de aula. Segundo Clément (2010, p. 64), as práticas sociais foram introduzidas por Martinand $(1986,2001)$ como importante referência da transposição didática, levando em conta que há diversos ambientes de formação, como, por exemplo, a prática profissional, a prática de cidadania e qualquer outra prática social. $\mathrm{O}$ autor também relata que o conhecimento científico do pesquisador é abarcado por suas práticas de investigação, tanto ao nível das tecnologias a que tenha acesso quanto ao nível das referências bibliográficas que citou e influenciam na sua investigação.

Por sua vez, a maioria das práticas sociais é sustentada por valores, pois cada pessoa faz escolhas que refletem os seus valores. Dessa forma, como o próprio autor diz, "os valores claramente interagem com as práticas sociais (interações VP)" (CLÉMENT, 2010, p.63, tradução nossa).

Muitos pesquisadores tem preterido o conceito de transposição didática (CAILLOT, 1996), apontando limitações e restrições no conceito, principalmente em relação ao papel do saber sábio proposto por Chevallard como sendo o único conhecimento de referência, desconsiderando as práticas sociais e mostrando-se restrito às Ciências matemáticas, não podendo ser generalizada para as diferentes áreas do conhecimento, já que cada uma tem uma história particular de construção e uma epistemologia própria.

Alguns autores possuem formas diferentes de compreender esse processo. Por exemplo, Bernstein (1996) compreende que o discurso pedagógico relativo a toda prática de instrução é um discurso recontextualizador.

Como se percebe, o referencial teórico de Bernstein, especialmente seu conceito de recontextualização, guarda proximidade com o conceito de transposição didática de Chevallard, pois diz respeito às transformações que o saber sábio ou o discurso científico sofre ao passar para os contextos de ensino. Porém, para Chevallard, o foco de análise é a transposição dos conceitos científicos no processo de ensino, tendo por referência, ainda, o saber sábio, enquanto que, para Bernstein, 
o foco é estudar a transferência dos textos entre diferentes contextos de produção e reprodução, mediada pelas relações de poder e pela regulação do discurso de ordem social. Assim, para Marandino (2004),

[...] uma das principais diferenças entre a transposição didática e a recontextualização está na compreensão do papel da "ordem social" na transformação do conhecimento científico e na produção do saber a ser ensinado e do discurso pedagógico. Para Chevallard, a legitimação acadêmica se sobrepõe à social. Para Bernstein, o discurso regulativo - de ordem social - é o legitimador. (p. 104)

\subsubsection{A organização e interação dos saberes}

Para além da caracterização do conhecimento escolar como um conhecimento científico transposto ou recontextualizado, é necessário que o conhecimento possa ser compreendido, também, a partir das suas diferentes formas de organização e interação, o que envolve compreender o conceito de interdisciplinaridade.

O conceito de interdisciplinaridade pode ser considerado como um conceito ainda em construção e, portanto, assumindo ainda múltiplas interpretações que o consolida como um conceito polissêmico. Fazenda (2002) salienta que encontrar um limite objetivo de sua abrangência conceitual significaria concebê-lo numa ótica também disciplinar, concordando com Leis (2005) que afirma que a tarefa de busca de definições finais para a interdisciplinaridade seria algo propriamente disciplinar, já que não existe uma definição única possível para esse conceito.

Diferentemente dos conhecimentos disciplinares, os conhecimentos interdisciplinares não são considerados paradigmáticos. A necessidade da interdisciplinaridade na produção e na socialização do conhecimento no campo educativo vem sendo discutida por vários autores, principalmente por aqueles que pesquisam as teorias curriculares e as epistemologias pedagógicas. De modo geral, a literatura sobre esse tema mostra que existe pelo menos uma posição consensual quanto ao sentido e à finalidade da interdisciplinaridade: ela busca responder à necessidade de superação da visão fragmentada nos processos de produção e socialização do conhecimento. Trata-se de um movimento que caminha para novas 
formas de organização do conhecimento ou para um novo sistema de sua produção, difusão e transferência, como propõem Gibbons et al. (1997).

A partir da análise de algumas contribuições ao conceito de interdisciplinaridade do ensino feitas por alguns peritos no assunto, conclui-se que

[...] existe uma preocupação em definir a terminologia adotada, embora ela se baseie em diferentes pressupostos. Posto que a terminologia adotada é bastante vasta, a tendência mais acentuada é restringir-se a quatro conceitos básicos: pluri, multi, inter e transdisciplinaridade; em geral, existe uma gradação nesses conceitos, que se estabelece na esfera de coordenação e cooperação entre as disciplinas. (FAZENDA, 2002, p.31)

Segundo Fazenda (2002), muitos pesquisadores têm procurado definir a interdisciplinaridade, mas muitas vezes se perdem na diferenciação de aspectos como multi, pluri e transdisciplinaridade, ou mesmo com a forma como o movimento da interdisciplinaridade se desenvolve, procurando fazer retrospectivas históricas da evolução do conhecimento através dos séculos.

Para Pontuschka (1993), a interdisciplinaridade se apresenta como uma metodologia em que se respeita a especificidade de cada área, procurando estabelecer e compreender as relações entre os conhecimentos sistematizados, ampliando o espaço de diálogo na direção da negociação de ideias e da aceitação de outras visões.

Araújo (2003) aponta que a circulação de conceitos, as interferências entre várias disciplinas em campos policompetentes, e a busca por novas explicações para os fenômenos da vida humana e da natureza acabam por quebrar o isolamento das disciplinas. Daí surgem novos termos para definir esse novo paradigma. Na visão desse pesquisador, e que também é a nossa, interdisciplinaridade

[...] refere-se àquilo que é comum a duas ou mais disciplinas ou campos de conhecimento. Muita gente pode acreditar que trabalha de forma interdisciplinar apenas porque se reúne com colegas de outras áreas, mantendo, no entanto, a fragmentação do estudo... De outra maneira, quando existe troca e cooperação entre os profissionais envolvidos, ou entre as áreas envolvidas, aí sim podemos chamar de "trabalho interdisciplinar". Não existe uma mera superposição de interesses, mas uma verdadeira interação e um compartilhamento de ideias, opiniões e explicações. (ARAÚJO, 2003, p,19) 


\subsubsection{Natureza da Ciência}

O segundo eixo, o da Natureza da Ciência, diferentemente do primeiro, possui seu foco na

[...] compreensão da natureza da ciência e dos fatores que influenciam sua prática, deflagrando a importância de que o fazer científico também ocupa espaço nas aulas de mais variados modos, desde as próprias estratégias didáticas adotadas, privilegiando a investigação em aula, passando pela apresentação e pela discussão de episódios da história das ciências que ilustrem as diferentes influências presentes no momento de proposição de um novo conhecimento; [...] (SASSERON \& CARVALHO, 2015, p. 57)

Para um aprofundamento maior sobre esse eixo, buscamos compreender as relações entre a Natureza da Ciência $(\mathrm{NdC})$ e a História da Ciência $(\mathrm{HC})$ e entre a $\mathrm{NdC}$ e as características específicas e gerais da Ciência.

\subsubsection{A Natureza da Ciência e sua relação com a História da Ciência}

Tanto a Natureza da Ciência (NdC), como a História da Ciência $(\mathrm{HC})$ estão envoltas em uma polissemia de significados e abrangência, havendo diferentes interpretações e compreensões.

A inclusão da $\mathrm{HC}$ na educação científica vem sendo recomendada enquanto estratégia pedagógica adequada para discutir certas características da $\mathrm{NdC}$ devido nutrir o processo de ensino e aprendizagem de aspectos epistemológicos da construção da ciência, permitindo a caracterização da ciência como um empreendimento humano (ALLCHIN, 1999; ABD-EL-KHALICK e LEDERMAN, 2000).

Há várias abordagens possíveis para a $\mathrm{NdC}$ que envolvem diferentes enfoques da construção do conhecimento científico. Assim, ao se almejar o ensino e aprendizagem da NdC é necessário especificar a abordagem a ser utilizada, pois ela pode ser embasada em perspectivas filosóficas, históricas ou sociológicas. 
Um dos aspectos da HC, destacado pelos historiadores e filósofos, e que focalizaremos nessa dissertação, refere-se às abordagens internalistas e externalistas da HC, uma vez que possuem grande influência para a aprendizagem da NDC pelos estudantes.

As discussões acerca das abordagens internalistas e externalistas da HC são complexas e um exemplo dessa complexidade está na diversidade de interpretações fornecidas por historiadores e filósofos, mas que não desenvolveremos aqui nesse texto.

Em síntese, a abordagem externalista, também chamada de abordagem sociológica etc., possui um foco mais direcionado à análise dos fatores extracientíficos presentes no desenvolvimento do conhecimento científico, propondo uma visão sociológica das relações Ciência, Tecnologia, Sociedade e Ambiente (CTSA).

Já a abordagem Internalista da História da Ciência, por sua vez, é interpretada como abordagem racional, abordagem implícita etc., possuindo um foco mais na dimensão racional da Ciência, baseado na análise de seus conteúdos conceituais. A utilização dessa abordagem no contexto do Ensino de Ciências está sempre associada à preocupação com o desenvolvimento dos conceitos.

Como Sasseron e Carvalho (2008) separam a contextualização CTSA da Natureza da Ciência, compreende-se que a natureza da Ciência é apropriada pelas autoras de forma a privilegiar, sobretudo, o viés internalista da História da Ciência. No entanto, concordamos com Barberousse et al. (2000) quando diz que a separação radical entre essas duas abordagens implicaria em considerar que a ciência progride apenas devido às suas necessidades internas, ou, no extremo oposto, que se desenvolveria apenas considerando as ações e motivações dos cientistas no estudo da produção do conhecimento científico, sem levar em conta a especificidade do conhecimento produzido.

\subsubsection{A Natureza da Ciência e as características específicas e gerais da Ciência}

A Natureza da Ciência ( $\mathrm{NdC}$ ) abrange um leque de estudos e competências acerca dos embasamentos da epistemologia e da filosofia, além dos fatos e conhecimentos relativos à Ciência. Nesse momento, apresentaremos a NdC dentro 
de um enfoque mais voltado à caracterização da área da ciência em termos de suas peculiaridades e diferenças.

Quando iniciamos um leigo a uma área da Ciência, muitas vezes negligenciamos o seu acesso à filosofia e à história e natureza da ciência, entendendo, muitas vezes, que a ciência é uma só. De fato, a natureza deve ser pensada como algo único e genérico, para que possamos ter o entendimento de mundo de forma integral e completa, afinal a química, a física, a biologia e a matemática estão integradas para que possamos fazer nossas atividades mais básicas possíveis. Entender a natureza da Ciência nos possibilita compreender sua estrutura e desenvolvê-la, bem como entender como e de que forma ela instiga e é instigada.

Muitas vezes, essa visão de que a Ciência deve ser trabalhada como única e geral para que possamos entender essas atividades expostas acima se confundem com uma visão simplista de ciência, dando a entender que as ciências são sempre formadas pelos mesmos valores, regras e preceitos.

Como podemos dizer que a natureza da Ciência é sempre a mesma? Como podemos afirmar que os parâmetros para todas as ciências são sempre estes ou aqueles? Como podemos indicar a existência de apenas um método científico geral?

Como bem lembra Gil Pérez et al. (2001):

[...] essas concepções aparecem associadas entre si, como expressão de uma imagem global ingênua da ciência que se foi decantando, passando a ser socialmente aceite. De fato, essa imagem típica da ciência parece ter sido assumida por autores do campo da educação, que criticam como características da ciência aquilo que são apenas visões deformadas da mesma. (p.164)

E complementa:

[...] Essa é uma leitura, quanto a nós, incorreta. Com efeito, como pode afirmar-se que a ciência clássica é - como é costume dizer-se - puramente analítica, se o seu primeiro edifício teórico significou a integração de dois universos considerados essencialmente diferentes, derrubando a suposta barreira entre o mundo celeste e o sublunar? (p.164).

Para que façamos um entendimento do que é a ciência na sua esfera básica e por que ocorre esses erros de concepções, recorremos à Baldinato e Porto (2007), 
onde temos que lembrar, muitas vezes, que os professores possuem concepções associadas a

Um modelo historiográfico continuísta, internalista, acumulativo, que olha para o passado buscando os "precursores" das idéias científicas atuais, avaliando o pensamento de outras épocas por meio dos critérios da ciência de hoje, não contribuirá para a construção de uma visão de ciência condizente com os objetivos atuais do ensino. (p. 8).

Trabalhar a natureza da Ciência (NdC) busca justamente sanar essa lacuna, possibilitando reconhecer sua relação com a sociedade e de que forma 0 conhecimento se desenvolve, assim como os valores e crenças.

Nessa perspectiva, voltamos à discussão sobre as especificidades de cada área científica e aspectos gerais da ciência como um todo. As áreas presentes dentro da grande área de conhecimento das Ciências Naturais e das Terras possui semelhanças entre $\mathrm{si}$, assim como membros de uma mesma família possui semelhanças, porém também possui suas especificidades e diferenças com identidades únicas e próprias, assim como as áreas das ciências que compõem essa mesma grande área.

Assim, conforme aponta Irzik e Nola (2011, p. 592),

[...] podemos ver mais claramente que nem todas as disciplinas científicas compartilham todas as características listadas em todas as categorias. Nós admitimos que todos compartilham a observação e a inferência, mas estes são dificilmente definidores da ciência, e não são suficientes para demarcar a ciência de outros empreendimentos humanos. Assim, deixando de lado essas duas atividades comuns, vemos que as ciências compartilham algumas ou a maioria das características de cada categoria, mas não todas, de modo que são semelhantes em relação a algumas características, mas diferentes em relação a outras. No entanto, dadas quaisquer duas disciplinas ensinadas nos cursos de ciências, existem semelhanças, sobreposições e cruzamentos suficientes que as tornam "ciências". Em outras palavras, o que une diversas disciplinas da física às ciências da terra, da cosmologia à vida e ciências ambientais é a semelhança da família entre elas com relação às características dentro de cada categoria. 
Segundo Moura (2014), alguns autores entendem que desenvolver a natureza da Ciência na educação pressupõe discutir seus conceitos, apontados como atributos na edificação do conhecimento científico, sendo aceito pela comunidade científica. Entre eles, se destacam: McComas e colaboradores (1998), Pumfrey (1991) e Gil Pérez e colaboradores (2001). Os autores relatam em seus artigos um conjunto de aspectos consensuais que são resumidos abaixo:

- A Ciência se transforma, tem dinâmica própria e objetiva entender os fenômenos naturais;

- Inexiste uma metodologia científica global;

- A teoria não é consequência da observação/experimento e vice-versa;

- A Ciência contém aspectos de todo uma conjuntura social, cultural, política etc., que desenvolve sua estrutura;

- Os pesquisadores lançam mão de ferramentas como o pensamento, crenças próprias, forças externas etc., para fazer Ciência.

Segundo Moura (2014), formar indivíduos críticos é a base do ensino de Ciências, sendo necessário, portanto, não apenas ensinar conteúdos científicos mas, sobretudo, ensinar sobre Ciência, a partir da Natureza da Ciência que, de uma perspectiva bem ampla e geral, "podemos dizer que envolve um arcabouço de saberes sobre as bases epistemológicas, filosóficas, históricas e culturais da Ciência. Compreender a natureza da ciência significa saber do que ela é feita, como elaborála, o que e por que ela influencia e é influenciada" (p. 33).

Lederman (1992) assinala que a NdC "geralmente se refere aos valores e suposições inerentes ao desenvolvimento do conhecimento científico" (LEDERMAN, 1992, p. 331), enfatizando a tese dos valores contidos na Ciência.

Para Almeida e Farias (2011), a NdC forma um limite heurístico inserido na área de estudos da História e Filosofia da Ciência (HFC), a qual constituem uma vertente da didática das ciências. A NdC tem se mostrado polissêmica, na forma variável de sua conceituação para o termo, todavia, segundo Moura (2014), a concepção adotada pode ser entendida: 
[...] como um conjunto de elementos que tratam da construção, estabelecimento e organização do conhecimento científico. Isto pode abranger desde questões internas, tais como método científico e relação entre experimento e teoria, até outras externas, como a influência de elementos sociais, culturais, religiosos e políticos na aceitação ou rejeição de ideias científicas. (p. 32)

Forato, Pietrocola e Martins (2011) destacam que a inclusão de teorias sobre a $\mathrm{NdC}$ é indispensável para construção de ideias entre as aprendizagens científicas e as capacidades de um indivíduo da atualidade. Contudo, os conteúdos técnicos não devem ser ignorados, devendo sempre ser considerados num ensino sobre e pela Ciência.

Para construir uma compreensão afinada acerca da NdC é necessário, portanto, aportar no desenvolvimento do estudo com os conteúdos específicos e problemáticas acerca da construção da Ciência, de forma que a educação não a descontextualize e os estudantes entendam a metodologia de construção do conhecimento, os atributos do trabalho científico e suas várias peculiaridades, possuindo a competência de tomar decisões fundamentadas e colaborar em argumentações, onde o grupo científico tenha eco (MOURA, 2014).

\subsubsection{Contextualização}

O terceiro eixo, o da contextualização, preocupa-se com a compreensão dos fatores mais externos à Ciência, com o foco nos aspectos culturais, sociais, éticos, políticos etc. que circundam a prática da Ciência, buscando encontrar subsídios para o exame de problemas do dia-a-dia que envolvam conceitos científicos ou conhecimentos advindos deles. Segundo as autoras, esse eixo está relacionado ao

[...] entendimento das relações entre ciência, tecnologia, sociedade e ambiente, permitindo uma visão mais completa e atualizada da ciência, vislumbrando relações que impactam a produção de conhecimento e são por ela impactadas, desvelando, uma vez mais, a complexidade existente nas 
relações que envolvem o homem e a natureza [...] (SASSERON \& CARVALHO, 2015, p. 57)

Como já discutido no subitem 4.2.2.1, a separação entre a natureza da Ciência e a contextualização como eixos distintos da alfabetização científica (AC), acaba por considerar a dimensão externalista da ciência como parte do eixo da contextualização e não como uma das dimensões da Natureza da Ciência, o que não gera tantas implicações, já que tanto as dimensões internalistas e externalistas da história da Ciência continuam servindo como eixos centrais para a AC. No entanto, como já destacado no parágrafo final do item 4.1 , isso explicita uma certa fragilidade e imprecisão na caracterização em separado dos eixos de AC "natureza da ciência" e "contextualização".

Para aprofundarmos a compreensão sobre esse terceiro eixo da $A C$, focalizamos nossa discussão em dois aspectos principais:

- a importância da contextualização para a significação dos conceitos,

- a contextualização na perspectiva das relações entre Ciência, Tecnologia, Sociedade e Ambiente (CTSA).

\subsubsection{A importância da contextualização para a significação dos conceitos}

O termo "contextualização começou a ser utilizado a partir da promulgação dos Parâmetros Curriculares Nacionais, porém, segundo Kato e Kawasaki (2011), apesar de o termo contextualização estar presente nos documentos curriculares oficiais mais recentes, o seu significado, para o ensino, de um modo geral, não é recente e tampouco possui origem nesses documentos. Propostas curriculares, oficiais ou não, anteriores a estas, já o preconizavam sob diferentes termos e formas.

Para Machado (2004, p. 146), a palavra mais adequada deveria ser contextuação, pois o ato de se referir ao contexto é expresso pelo verbo contextuar, de onde deriva a palavra contextuação. Segundo Machado (2005, p. 53), "etimologicamente, contextuar significa enraizar uma referência em um texto de onde 
fora extraída e longe do qual perde parte substancial de seu significado", sendo, portanto, fundamental para a atribuição de significações aos conceitos na medida que possibilita a percepção de aplicações e implicações dos conceitos no mundo real, ampliando a qualidade das condições para a apropriação de um dado conhecimento e sua aprendizagem significativa.

No entanto, a contextualização ainda é compreendida numa perspectiva ingênua e simplista, como exemplos, ilustrações e contextos visando apenas situar um determinado assunto, ou mesmo associada a cenários passivos, estáticos e decorativos para o desenvolvimento de algum tipo de problematização numa aula de Ciências, assumindo um caráter meramente motivacional e compreendido como facilitador da aprendizagem, independentemente do uso que se faz dela. Por exemplo, em livros didáticos de Química, (WARTHA e ALÁRIO, 2005) observaram que a ideia de contextualização se restringia à exemplificação de fatos do dia a dia e à descrição científica de fatos e processos.

\subsubsection{A contextualização na perspectiva das relações entre Ciência, Tecnologia, Sociedade e Ambiente}

$\mathrm{Na}$ Educação científica, pode-se dizer que o desenvolvimento científico e tecnológico surgiu devido às necessidades das sociedades, principalmente nos países capitalistas. Com o advento da segunda guerra mundial, onde foram utilizadas as tecnologias de destruição em massa, como bombas químicas e nucleares, iniciou-se uma grande preocupação com a vida e o meio ambiente (SANTOS, 2002), ampliandose uma crítica à tecnologia e à ciência que a gerou, estabelecendo, desde sua essência, uma relação de conflito entre o ambiental e a tecnologia.

Segundo Santos e Mortimer (2001), a necessidade de alfabetizar em Ciência, Tecnologia e Sociedade (CTS) não é pelo fato de mostrar coisas belas e atrativas na ciência, mas sim de oportunizar a todos a igualdade nas tomadas de decisão.

Os estudos sobre ciência, tecnologia e sociedade não possuem relevância somente na área acadêmica, onde ocorre a maioria dos questionamentos sobre a ciência e a tecnologia, mas, sobretudo, junto à população em geral devido à sua 
relevância pública (BAZZO; VON LINSINGEN; PEREIRA, 2003). Nessa direção, a perspectiva CTS

[...] corresponde ao estudo das interrelações existentes entre a ciência, a tecnologia e a sociedade, constituindo um campo de trabalho que se volta tanto para a investigação acadêmica como para as políticas públicas. Baseiase em novas correntes de investigação em filosofia e sociologia da ciência, podendo aparecer como forma de reivindicação da população para atingir uma participação mais democrática nas decisões que envolvem o contexto científico-tecnológico ao qual pertence. [...] (PINHEIRO, SILVEIRA, BAZZO, 2009, p.2).

Segundo Pinheiro, Silveira e Bazzo (2009), apesar desse movimento ter surgido na Europa, disseminou para todo o mundo, como resultado do avanço do progresso, que, apesar dos aspectos positivos que trouxe à vida das pessoas, encobre alguns perigos que precisam ser observados e pontuados.

Um dos pontos preocupantes do desenvolvimento científico-tecnológico é o fato desse desenvolvimento encobrir lucros e interesses das classes dominantes, persuadindo, muitas vezes, as classes menos favorecidas, cujas necessidades deixam de ser atendidas, uma vez que estão distantes das decisões políticas. (PINHEIRO; SILVEIRA E BAZZO, 2009).

Os estudos e programas com temática CTS vêm se desenvolvendo desde 0 seu início em três grandes direções (BAZZO, VON LINSINGEN, PEREIRA, 2003):

- No campo da pesquisa, os estudos CTS têm sido colocados como uma alternativa à reflexão acadêmica tradicional sobre a ciência e a tecnologia, promovendo uma nova visão não essencialista e socialmente contextualizada da atividade científica;

- No campo da política pública, os estudos CTS têm definido a regulação social da ciência e da tecnologia, promovendo a criação de diversos mecanismos democráticos que facilitam a abertura de processos de tomada de decisão em questões concernentes a políticas científico-tecnológicas;

- No campo da educação, esta nova imagem da ciência e da tecnologia na sociedade tem cristalizado a aparição de programas e materiais CTS no ensino secundário e universitário em numerosos países. (p. 127) 
Santos e Mortimer (2001) acham que temos que tomar cuidado com a utilização dos modelos curriculares de outros países, pois, muitas vezes, esses modelos são trazidos sem a devida contextualização local, ou seja, sem considerar as necessidades específicas de cada país. Destacam, também, a formação de professores como um problema a ser trabalhado.

Segundo Santos e Mortimer (2001):

A informação científica sobre o tema envolvido é imprescindível, todavia ela não é suficiente se desejamos ir além da mera alfabetização de fatos científicos. O letramento científico e tecnológico necessário para os cidadãos é aquele que os prepara para uma mudança de atitude pessoal e para um questionamento sobre os rumos de nosso desenvolvimento científico e tecnológico. (p. 107)

Para esses autores, isso só ocorrerá se os professores de ciências mudarem também sua postura na sala de aula, nas discussões sobre temas que envolvem aspectos culturais, ambientais, econômicos, políticos, sociais e éticos, já que

\footnotetext{
Uma educação científica que se pretende neutra é ideologicamente tendenciosa. Ela, ao invés de preparar o cidadão para participar da sociedade, pode reforçar valores contrários ao ideal de democracia e de cidadania ao não questioná-los. (SANTOS E MORTIMER, 2001, p.107).
}

Concomitante à apropriação de contextualização, temos também a apropriação da letra "A" junto com a sigla CTS, resultando na sigla CTSA. Esta sigla pode dividir opiniões, segundo aponta Schneider-Felício (2018), pontuando que alguns autores se mostram contrários à sigla CTSA pelo entendimento de que a explicitação da dimensão ambiental não se faz necessária devido entenderem que o movimento CTS já nasce com pesquisas voltadas para a área ambiental e, portanto, já contempla o ambiental dentro da dimensão social.

Porém, é sabido que o uso da contextualização dentro de uma abordagem CTS geralmente tem privilegiado as relações CT, em detrimento de uma maior problematização social e ambiental. Assim, a incorporação da letra "A" à sigla CTS, 
possibilita dar ênfase à dimensão ambiental, evidenciando e reforçando, ao mesmo tempo, os aspectos sociais nos quais o ambiental está incluso, de forma que o social e o ambiental coexistam, evitando-se, assim,

[...] interpretações reducionistas do movimento CTS/CTSA, que ora desconsideram sua dimensão social (política, econômica, ética, dentre outras), ora sua dimensão ambiental, ou as consideram separadamente. É preciso buscar uma visão crítica da realidade para superar os problemas do sistema social tecnocrático ao qual estamos submetidos. (SCHNEIDERFELÍCIO, 2018, p. 18)

Essa visão crítica de sociedade também deve ser considerada na contextualização CTSA a partir de seu uso numa perspectiva crítica que, segundo Santos (2007), significa ampliar o olhar sobre o papel da ciência e da tecnologia na sociedade a partir das discussões, em sala de aula, de questões econômicas, políticas, sociais, culturais, éticas e ambientais. Essas discussões envolvem valores e atitudes, mas precisam estar associadas à compreensão conceitual dos temas relativos a esses aspectos sociocientíficos, pois a tomada de decisão requer, necessariamente, que haja compreensão dos conceitos científicos relativos à temática em discussão. 


\section{Metodologia}

Neste item, é explicitada a abordagem e os referenciais metodológicos assumidos, bem como todos os passos do percurso metodológico trilhados na pesquisa, destacando a pertinência e a limitação de cada ação em relação à tentativa de alcançar os objetivos e metas propostos na pesquisa.

\subsection{Abordagem da pesquisa e a opção pela análise de Conteúdo}

A pesquisa desenvolvida, como já discutido em nossa revisão bibliográfica sobre pesquisas do Estado da Arte e Estado do conhecimento, possui um caráter descritivo e inventariante, assumindo uma abordagem tanto qualitativa, quanto quantitativa, sendo a dimensão quantitativa associada ao cálculo quantitativo de cada um dos descritores da produção analisada e a dimensão qualitativa associada às categorias construídas a partir da Metodologia de Análise do Conteúdo (BARDIN, 1991).

Os dados quantitativos possibilitam reconhecer a presença, a ausência e, acima de tudo, a quantidade de presença de determinadas informações no conjunto analisado. No entanto, o quantitativo foi assumido apenas associado aos descritores já apresentados nos catálogos de teses e dissertações da CAPES e que são descritos no anexo A desta dissertação, não sendo utilizada a perspectiva de análise do conteúdo, em termos de cálculos de frequência de determinado termo ou expressão, devido estarmos tratando de análise de resumos, o que faz da análise de frequência do termo algo sem sentido, pelas restrições textuais do próprio resumo.

Assim, a análise de conteúdo (AC) é adotada nesta pesquisa como ferramenta metodológica dentro de uma perspectiva qualitativa. A opção do uso da AC quando comparada a outras métodos, tais como a análise do discurso, está muito relacionada ao fato da pesquisa focalizar o estudo da produção acadêmica a partir apenas dos seus resumos. Em nossa compreensão, o caráter informacional restrito dos resumos e a quantidade de resumos dificulta o uso de métodos de análise mais complexos, tornando a análise de conteúdo uma alternativa metodológica mais adequada dentro 
desse contexto, sendo empregada nas etapas 4, 5, 6c e 7 do percurso metodológico trilhado em nossa pesquisa.

De forma geral, assim como Bauer e Gaskell (2003, p.190), consideramos que a análise de conteúdo ${ }^{14}$ fornece "uma ponte entre um formalismo estatístico e a análise qualitativa dos materiais", característica esta que se apresenta como mais uma vantagem deste método, além de, também, reduzir a complexidade de uma coleção de textos, possibilitando a identificação e explicitação de várias características de um determinado corpus documental, possibilitando, por exemplo, a identificação de critérios de inclusão ou exclusão para a consolidação do nosso corpus documental.

No contexto dessa pesquisa, a análise de conteúdo é considerada, compreendendo três fases: a pré-análise; a exploração do material; o tratamento dos resultados, inferência e interpretação (BARDIN, 1991, p. 95). A pré-análise:

[...] é a fase de organização propriamente dita. Corresponde a um período de intuições, mas, tem por objetivo tornarem operacionais e sistematizar as ideias iniciais, de maneira a conduzir a um esquema preciso do desenvolvimento das operações sucessivas, num plano de análise. Esta primeira fase, de modo geral, tem triplo objetivo, a saber, a escolha dos documentos a serem submetidos a análise, a formulação das hipóteses e dos objetivos e a elaboração de indicadores que fundamentem a interpretação final. (BARDIN, 1991, p.95)

Cumpre destacar, ainda, que essa primeira leitura dos trabalhos pode ser caracterizada como "flutuante", tal como designada por Bardin, isto é, realizada com o objetivo de "estabelecer contato com os documentos a analisar" e de "conhecer o texto, deixando-se invadir por impressões e orientações". (BARDIN, 1991, p. 96). Posteriormente, nas etapas seguintes da pesquisa, novas leituras foram realizadas de forma mais atenta, buscando reconhecer objetos de registro específicos,

\footnotetext{
${ }^{14}$ Para Liakopoulos (2003), "a análise de conteúdo é um exercício de redução de dados onde o texto é codificado em determinadas categorias. A transformação do texto original em categorias quantificadas é feita através de um referencial de codificação que abrange todo aspecto importante do material de pesquisa. O desafio é reduzir uma grande quantidade de material em unidades significativas de análise, sem perder a essência (conteúdo, intenção) do material escrito original (p. 237).
} 
considerando o texto completo do resumo como o objeto de contexto, o que possibilitou reconhecer, de forma mais efetiva, possíveis significados atribuídos ao objeto de registro.

A análise de conteúdo também foi utilizada com o objetivo de estabelecer categorias de análise, caracterizando-se como "análise por categorias" ou "análise categorial". De acordo com Bardin (1991, 117), "a categorização é uma operação de classificação de elementos constitutivos de um conjunto, por diferenciação e, seguidamente, por reagrupamento segundo o gênero (analogia), com critérios previamente definidos".

Para esta pesquisa, dentre as diferentes possibilidades de categorização existentes, optamos pela investigação dos temas ou análise temática, que se caracteriza por recortar ideias do texto, enunciados e proposições que podem ter significações isoláveis mas que mantenham entre si o mesmo nível de abrangência. De acordo com Bardin (1991, p. 105), "fazer uma análise temática consiste em descobrir os 'núcleos de sentido' que compõem a comunicação e cuja presença, ou frequência de aparição, podem significar alguma coisa para o objetivo escolhido".

\subsection{As etapas do percurso metodológico}

Os passos que constituem o percurso metodológico trilhado durante a pesquisa estão representados por um conjunto de 7 etapas, descritas a seguir:

- Etapa 1: Escolha da base de dados, do período e do material a ser analisado.

- Etapa 2: Recuperação do conjunto total (conjunto A) de resumos de teses e dissertações defendidas no período de 2013 a 2017.

- Etapa 3: Caracterização geral e quantitativa do Conjunto A.

- Etapa 4: Seleção e análise do conjunto de resumos de teses e dissertações (conjunto B) nas quais alguma das seguintes expressões - "alfabetização científica", "letramento científico" e "enculturação científica" - foram identificadas.

- Etapa 5: Seleção e definição do corpus documental da pesquisa (Conjunto C)

- Etapa 6: Caracterização do corpus documental da pesquisa (Conjunto C). 
- Etapa 6a: Caracterização do total de produção e do contexto de produção.

- Etapa 6b: Caracterização do tipo de produção.

- Etapa 6c: Caracterização das pesquisas relacionadas à produção.

- Etapa 7: Caracterização da apropriação dos três eixos estruturantes da AC.

- Etapa 7a: Análise da apropriação do eixo "conhecimento científico".

- Etapa 7b: Análise da apropriação do eixo "contextualização".

- Etapa 7c: Análise da apropriação do eixo "Natureza da Ciência" .

Um maior detalhamento de cada uma das etapas é apresentado nos itens apresentados na sequência.

\subsection{Etapa 1: A escolha da base de dados, do período e do tipo de material a ser analisado}

Neste item, são explicitadas as justificativas relativas à escolha da base de dados de Teses e Dissertações da CAPES, a definição do período a ser analisado e a opção pelo resumo como material a ser analisado para caracterização das produções acadêmicas.

\subsubsection{A escolha da base de dados de Teses e Dissertações da CAPES}

Para o desenvolvimento da pesquisa, as produções científicas foram recuperadas a partir da base de dados abertos ${ }^{15}$ de teses e Dissertações da CAPES ${ }^{16}$,

\footnotetext{
15 Os dados são considerados "abertos" quando qualquer pessoa pode livremente acessá-los, utilizá-los, modificálos e compartilhá-los para qualquer finalidade, estando sujeito a, no máximo, a exigências que visem preservar sua proveniência e sua abertura. $O$ acesso aos dados pode ser feito a partir do endereço (https://dadosabertos.capes.gov.br/)

${ }^{16}$ A Coordenação de Aperfeiçoamento de Pessoal de Nível Superior (CAPES) é uma fundação vinculada ao Ministério da Educação do Brasil que atua na expansão e consolidação da pós-graduação stricto sensu em todos os estados brasileiros.
} 
acessando, mais especificamente, os catálogos de Teses e Dissertações. A escolha por tal base reside na importância dessa base na indexação nacional de toda a produção de Teses e Dissertações brasileiras e a relevância desse tipo de produção para a produção científica como um todo.

No entanto, é importante frisarmos que, ao optarmos apenas por essa base de dados, estamos restringindo a nossa pesquisa em termos da produção acadêmica em nível de pós-graduação, excluindo-se outros tipos de produções científicas também relevantes, tais como: artigos científicos, capítulos de livro, trabalhos em congressos etc., o que faz com a pesquisa assuma a identidade de uma pesquisa de Estado do Conhecimento e não Estado da Arte , conforme já discutido no item 4.

Essa delimitação também foi feita, a fim de tornar a pesquisa exequível, já que foi desenvolvida no contexto de um mestrado acadêmico, que possui uma maior restrição de tempo para o desenvolvimento da pesquisa, necessitando recortes na pesquisa e a escolha de sistemas de menor complexidade ou extensão, mas que ainda possua um potencial de contribuição para o conhecimento científico.

Assim, é importante salientar que os resultados a serem discutidos nessa pesquisa, mesmo não podendo ser generalizados para toda a produção científica nacional envolvendo a temática da alfabetização científica, pode fornecer importantes e significativas informações sobre esse tipo de pesquisa no contexto da produção acadêmica em nível de pós-graduação, que, por sua vez, caracteriza-se como um conjunto muito relevante da produção científica.

\subsubsection{A definição do período analisado}

Considerando se tratar de uma pesquisa associada a um mestrado acadêmico, estabelecemos um recorte temporal dos últimos 5 anos, assumindo como data final a data de definição de nosso corpus documental, identificada como o ano de 2017. Assim, a pesquisa centrou-se na caracterização e análise da produção no período de 2013 a 2017, resultando na produção acumulada de 5 anos. Os anos de 2018, 2019 e 2020 não foram considerados em nosso estudo, pois quando da definição do corpus 
documental de análise, as teses e dissertações defendidas no período de 2018 a 2020 ainda não se encontravam consolidadas e validadas no catálogo da CAPES que reúne o conjunto de teses e dissertações nesse período.

\subsubsection{A opção pelo resumo como material a ser analisado para caracterização das produções acadêmicas}

A opção pelo resumo como material a ser analisado para caracterização das produções acadêmicas ocorreu devido possibilitar a análise de um conjunto maior de pesquisas e de aspectos, bem como a adequação da pesquisa desenvolvida em relação ao tempo disponível previsto num mestrado acadêmico, de forma a tornar a pesquisa exequível, mesmo compreendendo as limitações impostas pela análise de resumos de produções acadêmicas ${ }^{17}$ quando comparada à análise de um texto completo dessas produções.

\subsection{Etapa 2: Recuperação do conjunto total (Conjunto A) de resumos de teses e dissertações defendidas no período de 2013 a 2017}

Nesta etapa, foi feita a recuperação do conjunto total de resumos (conjunto $A$ ) de teses e dissertações, defendidas no período de 2013 a 2017, disponíveis no

\footnotetext{
17 Essas limitações se referem ao fato dos resumos nem sempre apresentarem uma estrutura que contemple aspectos básicos da pesquisa e, também, por conter um texto muito restrito, dificultando o reconhecimento de elementos que possam caracterizar, de forma mais ampla e completa, a pesquisa desenvolvida. Além dessas limitações intrínsecas, quando se compara resumos de produções acadêmicas de diferentes áreas do conhecimento, também é possível haver muitas diferenças entre os resumos em termos de sua estrutura devido às particularidades de cada área. Outro fator não menos relevante a ser considerado é o formato multipaper (COSTA, 2014; NASSI-CALÒ, 2013), cada vez mais presente nos Programas de Pós-Graduação Brasileiros e que amplia, ainda mais, a fragilidade estrutural e informativa dos resumos, pelo fato deste formato estruturar o trabalho acadêmico a partir de uma combinação de várias artigos independentes, com problematizações, objetivos e metodologias próprias, nem sempre estabelecendo relações diretas e orgânicas e sistemáticas com outros artigos que compõem o trabalho acadêmico estruturado nesse formato, fazendo com que o resumo nem sempre explicite uma síntese que corresponda adequadamente a pesquisa desenvolvida. Essa discussão sobre os diferentes formatos foi enfatizada no Editorial da Revista Nature (THE..., 2016).
} 
catálogo consolidado de teses e dissertações do conjunto de dados abertos ${ }^{18}$ da CAPES.

A opção pela recuperação a partir dos Catálogos de Teses e Dissertações da Capes se deu pelo fato desses catálogos já terem sido consolidados e validados pela própria CAPES em períodos específicos, tornando a recuperação mais fácil e menos arriscada quando comparada ao processo de recuperação que se utiliza dos mecanismos de busca da Plataforma Sucupira ${ }^{19}$. Até por isso, produções acadêmicas defendidas a partir de 2018 foram desconsideradas nesta pesquisa, pois, até a fase de início da análise do corpus documental, os dados ainda não haviam sido totalmente consolidados, restringindo-se a pesquisa na análise de resumos de teses e dissertações defendidas no período de 2013 a 2017, assumindo-se, portanto, um recorte temporal dessa produção acadêmica.

\subsection{Etapa 3: Caracterização geral do Conjunto A de resumos}

Nesta etapa, foi feita a caracterização geral e quantitativa do Conjunto A em termos dos mesmos descritores ${ }^{20}$ utilizados na caracterização geral do corpus documental da pesquisa e que estão descritos e detalhados nas etapas 7a, 7b e 7c da metodologia.

A partir dessa grande tabela (Conjunto A), consolidada e validada, tornou-se possível fazer uma caracterização geral e quantitativa da produção nesse período, a partir de cada um dos descritores, permitindo reconhecer possíveis tendências, movimentos e características da produção no período analisado referente a cada

\footnotetext{
18 Segundo a definição da Open Knowledge Internacional (https://okfn.org/), os dados são considerados "abertos" quando qualquer pessoa pode livremente acessá-los, utilizá-los, modificá-los e compartilhá-los para qualquer finalidade, estando sujeito a, no máximo, a exigências que visem preservar sua proveniência e sua abertura

${ }^{19}$ A Plataforma Sucupira é uma ferramenta on-line para coletar informações, realizar análises, avaliações e servir como base de referência do Sistema Nacional de Pós-Graduação (SNPG). O nome da Plataforma Sucupira é uma homenagem ao professor Newton Sucupira, autor do Parecer no 977 de 1965. O documento conceituou, formatou e institucionalizou a pós-graduação brasileira nos moldes dos dias de hoje.

${ }^{20}$ Os descritores citados nesta etapa se referem aos descritores relativos à quantidade de produção, ao contexto de produção e às características do tipo de produção. Ver descrição de cada descritor no ANEXO A desta dissertação.
} 
descritor. Também foi feito um recorte associado à área de Ensino, que representa o conjunto no qual $70,29 \%$ do nosso corpus documental mostrou estar inserido, representando, portanto, o conjunto mais inclusivo e que possui maior potencial de influência nas características e possíveis tendências ou movimentos observados na produção, permitindo identificar a presença de alguma especificidade do corpus documental, já que sempre há a possibilidade de características e tendências de um conjunto menor apenas refletirem características e tendências do conjunto maior no qual está inserido.

\subsection{Etapa 4: Seleção e análise do conjunto de resumos de teses e dissertações} (Conjunto B) nas quais alguma das seguintes expressões - "alfabetização científica", "letramento científico" e "enculturação científica" - foram identificadas

Nesta etapa, a partir do conjunto A, foi feita a seleção do conjunto de resumos de teses e dissertações (conjunto B) nas quais alguma das seguintes expressões “alfabetização científica", "letramento científico" e "enculturação científica” - foram identificadas em algum dos três campos de indexação "título", "resumo" e "palavraschave".

A seleção desse Conjunto $B$ foi feita por meio do uso de ferramentas do Programa Excel ${ }^{21}$ utilizando-se a na análise de conteúdo (BARDIN, 1991) no qual cada uma das expressões citadas se configurou como unidade de registro ${ }^{22}$, sendo considerado, no processo de identificação, possíveis erros de ortografia e acentuação nas palavras presentes em cada uma das expressões, de forma a evitar a perda de informações.

\footnotetext{
${ }^{21}$ Foram utilizadas as funções PROCV e PROCH do Programa Excel, de forma associada, o que permitiu a identificação da presença de cada uma das expressões no corpo textual dos campos de indexação (título, resumo e palavras-chave) da produção acadêmica do Conjunto 01.

${ }^{22}$ A "unidade de registro", também nomeada como" unidade de significado" ou "unidade de análise", é o elemento unitário de conteúdo a ser submetido posteriormente à classificação, já que, para a análise de conteúdo, toda categorização ou classificação necessita definir o elemento unitário a ser classificado.
} 
As expressões citadas como unidades de registro não foram classificadas ou categorizadas, sendo considerada apenas a simples apropriação de cada expressão no corpo dos resumos das produções analisadas.

A partir da identificação realizada, foi feita uma análise comparativa e quantitativa entre os resumos do Conjunto B em termos da representatividade das expressões - "alfabetização científica", "letramento científico" e "enculturação científica, buscando-se reconhecer a simples apropriação de cada um dos termos na produção acadêmica do período analisado.

\subsection{Etapa 5: Seleção e definição do corpus documental da pesquisa (Conjunto C)}

Nesta etapa, visando à identificação do corpus documental final para a análise, foi realizada a leitura e análise dos resumos e dos títulos das produções do conjunto B selecionado na etapa 4, a fim de se assegurar a presença da temática da alfabetização científica no conjunto de teses e dissertações a serem analisadas.

Devido à apropriação da temática da alfabetização se caracterizar como algo amplo e difuso, as estratégias para recuperação dos resumos que mostrassem esse tipo de apropriação também se mostraram muito complexas e sem validação. Como a estrutura textual limitada dos resumos impõe a necessidade de considerarmos, como unidades de registro, elementos que se mostrem explícitos e claros, optamos por considerar, como conjunto de interesse, apenas os resumos que explicitaram a expressão "alfabetização científica" nos campos de indexação "título", "resumo" ou "palavras-chave", conscientes de que, ao assumir essa opção, é facilitada a seleção e identificação dos resumos, ao mesmo tempo que se restringe as "pesquisas em alfabetização científica" às produções que incorporaram explicitamente essa expressão no corpo textual de seus resumos.

Nessa direção, foi adotada a "análise de conteúdo" (BARDIN, 1991) como ferramenta metodológica, com o objetivo de reconhecer características na produção analisada (Conjunto B) que pudessem expressar critérios de exclusão ou inclusão 
para a consolidação do corpus documental final da pesquisa, formado pelo conjunto de resumos (Conjunto $\mathrm{C}$ ) nos quais foi possível ser observado algum tipo de apropriação da temática da alfabetização científica.

\subsection{Etapa 6: Caracterização do corpus documental da pesquisa (conjunto C)}

Neste item, é descrita a etapa de caracterização do corpus documental da pesquisa (conjunto $\mathrm{C}$ ), definido como o conjunto de resumos de teses e dissertações que mostraram explicitamente se apropriar da temática de alfabetização científica. Essa etapa de caracterização foi dividida em 3 subetapas, cada uma associada a uma dimensão específica de caracterização.

\subsubsection{Etapa 6a: Caracterização do total de produção e do contexto de produção}

A caracterização do total de produção foi feita a partir do cálculo de número de

teses e dissertações (Conjunto $\mathrm{C}$ ) defendidas em cada um dos anos, no período de 2013 a 2017, e que se apropriaram da temática da Alfabetização Científica. Já o contexto de produção foi caracterizado a partir de descritores já contemplados no catálogo da CAPES. São eles:

- Grande Região

- Estado

- Instituição de Ensino Superior (IES)

Todos esses três descritores já estão contemplados nos catálogos de teses e dissertações da CAPES como indexadores da produção.

O total da produção em cada ano e no período foi comparada com os valores relacionados à produção acadêmica na área de Ensino e que corresponde à área na qual se situa $70,23 \%$ das pesquisas em $A C$ identificadas, de forma a possibilitar 0 
reconhecimento de alguma especificidade no conjunto analisado e que não reflita apenas as características do conjunto maior (produção na área de Ensino) da qual faz parte.

\subsubsection{Etapa 6b: Caracterização do tipo de produção}

A caracterização do tipo de produção foi feita a partir dos seguintes descritores:

- Tipo de produção (dissertação de mestrado profissional, dissertação de mestrado acadêmico, tese de doutorado)

- Grande área do Conhecimento a que se refere a produção

- Área do Conhecimento a que se refere o Programa de Pós-graduação associado à produção

Assim como descrito na etapa 6a, esses descritores considerados na etapa $6 \mathrm{~b}$ também já estão disponíveis como indexadores nos Catálogo de Teses e Dissertações da CAPES, não necessitando a utilização da análise de conteúdo, mas somente a quantificação e comparação dos dados no período analisado.

\subsubsection{Etapa 6c: Caracterização das pesquisas associadas à produção}

Diferentemente das etapas $6 \mathrm{a}$ e $6 \mathrm{~b}$, a caracterização das pesquisas foi feita a partir de uma análise de conteúdo, mais especificamente na perspectiva de uma análise categorial, discutida no item 5.1, focalizando a identificação da abordagem de pesquisa (qualitativa, quantitativa, quali-quanti) e outras características gerais da pesquisa.

Para a identificação da abordagem da pesquisa, foram definidos, a priori, os termos característicos (qualitativa, quantitativa, quali-quanti) e outras possíveis 
variações nesses termos, buscando identificar essas abordagens no corpo textual dos resumos analisados, considerando como unidade de contexto ${ }^{23}$ o próprio resumo.

Diferentemente, a identificação das características gerais das pesquisas se mostrou um processo mais complexo, necessitando leitura e releitura de todos os resumos com o objetivo de reconhecer elementos explicitados no corpo textual dos resumos que expressassem alguma característica da pesquisa.

\subsection{Etapa 7: Caracterização da apropriação dos três eixos estruturantes da AC}

As etapas de caracterização da apropriação de cada um dos três eixos estruturantes da AC são detalhadas separadamente nos itens que se seguem.

\subsubsection{Etapa 7a: Análise da apropriação do eixo "conhecimento científico"}

Nesta etapa, foi feita a análise da apropriação do eixo "conhecimento científico" em termos da área do saber ou disciplinar ao qual se refere e em termos da organização do conhecimento em suas dimensões disciplinar, interdisciplinar, transdisciplinar e multidisciplinar. A identificação de cada um dos elementos foi realizada a partir da leitura dos resumos e identificação explícita de termos associados diretamente a uma área do conhecimento ou a um tipo de organização do conhecimento.

Assim, nesta etapa foi utilizado a análise de conteúdo na perspectiva da análise categorial. No entanto, o reconhecimento da área do saber ou disciplinar foi realizado por meio da identificação explícita do nome da área ou pela presença de conteúdos relacionados diretamente a uma área do saber, enquanto que a análise relativa à organização do conhecimento ficou restrita à identificação dos termos "disciplinar",

\footnotetext{
${ }^{23}$ A unidade de contexto é uma unidade, de modo geral, mais ampla do que a de registro, servindo de referência a esta, fixando limites contextuais para interpretá-la.
} 
"interdisciplinar", "transdisciplinar", "multidisciplinar" e de variantes desses termos, assumindo-os como unidades de registro definidas a priori.

A percepção da importância de temas interdisciplinares nessas pesquisas fez com que aprofundássemos nossa análise em relação à natureza dessas temáticas, de forma a compreendermos a sua importância e características em relação à dimensão interdisciplinar das pesquisas em Alfabetização Científica.

\subsubsection{Etapa 7b: Análise da apropriação do eixo "contextualização"}

Nesta etapa, foi feita a análise da apropriação do eixo "contextualização" a partir da análise de conteúdo, na perspectiva da análise categorial. A identificação de cada um dos elementos associados ao eixo "contextualização" foi realizada a partir da leitura e releitura dos resumos guiada por alguns termos e siglas, tais como: context ${ }^{*}$, CTS, CTSA, socioamb*, sociocult*, científico-tecnológic* etc.

Abaixo, estão relacionadas as categorias identificadas a posteriori relacionadas ao eixo "contextualização" e que são discutidas e aprofundadas no item 6 desta dissertação.

- Aspectos, temas ou questões socioambientais

- Aspectos, temas ou questões sociocientíficas

- Aspectos, temas ou questões socioculturais

- Ciência, Tecnologia e Sociedade (CTS)

- Ciência, Tecnologia, Sociedade e Ambiente (CTSA)

- Contextualização genérica

- Cotidiano

- Educação Ambiental

- Saberes populares 


\subsubsection{Etapa 7c: Análise da apropriação do eixo "Natureza da Ciência"}

De forma similar à etapa anterior, foi feita a análise da apropriação do eixo "Natureza da Ciência" a partir da análise de conteúdo, na perspectiva da análise categorial. A identificação de cada um dos elementos associados ao eixo "contextualização" foi realizada a partir da leitura e releitura dos resumos guiada por alguns termos e siglas relacionados diretamente e explicitamente à natureza da ciência ( $\mathrm{NdC}, \mathrm{NdCT}$ etc. $)^{24}$, contemplando as dimensões filosófica e histórica, bem como outros termos, definidos a posteriori, que possam estar associados, de forma implícita, à ideia de Natureza da Ciência. 


\section{Resultados e discussão}

Neste item, são apresentados os dados e resultados obtidos, bem como as discussões, análises e argumentações guiadas pelos objetivos da pesquisa, definidos a priori. Os resultados, aqui apresentados, estão organizados em 3 itens principais.

- Análise comparativa da presença das expressões "alfabetização científica", "letramento científico" e "enculturação científica" citadas no título, resumo ou palavras-chave de teses e dissertações defendidas no Brasil, no período de 2013 a 2017.

- Identificação do corpus documental da pesquisa e reconhecimento do total de produção em alfabetização científica no período de 2013 a 2017.

- Caracterização do conjunto de teses e dissertações em alfabetização científica defendidas no Brasil no período de 2013 a 2017.

- Identificação das características mais internas e particulares das pesquisas em AC.

O detalhamento e discussão de cada um desses itens estão sistematizados a partir do item 6.1.

\subsection{Análise comparativa da presença das expressões "alfabetização científica",} "letramento científico" e "enculturação científica" citadas no título, resumo ou palavras-chave de teses e dissertações defendidas no Brasil, no período de 2013 a 2017

Neste item, é realizada a análise comparativa da presença das expressões "alfabetização científica" (AC), "letramento científico" (LC) e "enculturação científica"(EC) nos campos de indexação (título, resumo, palavras-chave) do conjunto de 324 teses e dissertações defendidas no Brasil, no período de 2013 a 2017, nas quais foram observadas a presença de alguma dessas expressões. Como já descrito, o objetivo dessa análise está em reconhecer a representatividade das citações à AC em relação à LC e EC, lembrando que a presença dessas expressões nos referidos 
campos de indexação não necessariamente determina uma efetiva apropriação de AC, LC e EC nas pesquisas desenvolvidas.

Como pode ser observado nos dados disponibilizados na Tabela 1, 83,95\% dessa produção acadêmica mostrou a presença exclusiva da expressão "alfabetização científica", número muito superior à apropriação da expressão Letramento Científico (16,89\%) e da expressão enculturação científica $(0,93 \%)$. Também se verifica que apenas $1,23 \%$ das produções apresentaram a presença conjunta de AC e EC.

Tabela 1 Distribuição, por ano de defesa, do conjunto de 324 teses e dissertações, defendidas no Brasil no período de 2013 a 2017, nas quais foram identificadas a presença dos termos "alfabetização científica", "letramento científico" e "enculturação científica" em algum dos campos de indexação (título, resumo, palavras-chave) ${ }^{25}$.

\begin{tabular}{|c|c|c|c|c|c|c|c|c|c|c|c|c|c|c|c|c|c|c|}
\hline \multirow{3}{*}{$\begin{array}{l}\text { PRESENÇA DOS TERMOS } \\
\text { AC/LC/EC }\end{array}$} & \multicolumn{18}{|c|}{ ANO DE DEFESA } \\
\hline & \multicolumn{3}{|c|}{2013} & \multicolumn{3}{|c|}{2014} & \multicolumn{3}{|c|}{2015} & \multicolumn{3}{|c|}{2016} & \multicolumn{3}{|c|}{2017} & \multicolumn{3}{|c|}{ TOTAL } \\
\hline & $\mathrm{N}^{(2)}$ & $\%^{(3)}$ & $\%^{(4)}$ & $\mathrm{N}^{(2)}$ & $\%^{(3)}$ & $\%^{(4)}$ & $\mathrm{N}^{(2)}$ & $\%^{(3)}$ & $\%^{(4)}$ & $\mathrm{N}^{(2)}$ & $\%^{(3)}$ & $\%^{(4)}$ & $\mathrm{N}^{(2)}$ & $\%^{(3)}$ & $\%^{(4)}$ & $\mathrm{N}^{(2)}$ & $\%^{(3)}$ & $\%^{(4)}$ \\
\hline AC & 38 & $90,48 \%$ & 13,95\% & 40 & $85,11 \%$ & $1014,70 \%$ & 59 & $89,39 \%$ & $21,69 \%$ & "59 & $7 \overline{76,62 \%}$ & $21,70 \%$ & 76 & $82,61 \%$ & $27,96 \%$ & 272 & $83,95 \%$ & $10100,00 \%$ \\
\hline LC & 2 & $4,76 \%$ & $4,44 \%$ & 7 & $14,89 \%$ & $15,54 \%$ & 5 & $7,58 \%$ & $11,11 \%$ & 16 & $20,78 \%$ & $35,56 \%$ & 15 & $16,30 \%$ & $33,35 \%$ & 45 & $13,89 \%$ & $100,00 \%$ \\
\hline $\mathrm{AC} / \mathrm{LC}$ & 2 & $4,76 \%$ & $49,96 \%$ & - & $0,00 \%$ & $0,00 \%$ & 1 & $1,52 \%$ & $25,01 \%$ & - & $0,00 \%$ & $0,00 \%$ & 1 & $1,09 \%$ & $25,03 \%$ & 4 & $1,23 \%$ & $100,00 \%$ \\
\hline EC & - & $0,00 \%$ & $0,00 \%$ & - & $0,00 \%$ & $0,00 \%$ & 1 & $1,52 \%$ & $33,32 \%$ & 2 & $2,60 \%$ & $66,68 \%$ & - & $0,00 \%$ & $0,00 \%$ & 3 & $0,93 \%$ & $100,00 \%$ \\
\hline Total Geral & 42 & $100,00 \%$ & $12,95 \%$ & 47 & $100,00 \%$ & $14,50 \%$ & 66 & $100,00 \%$ & $20,37 \%$ & 77 & $100,00 \%$ & $23,77 \%$ & 92 & $100,00 \%$ & $28,42 \%$ & 324 & $100,00 \%$ & $100,00 \%$ \\
\hline
\end{tabular}

(1) $\mathrm{AC}=$ Alfabetização científica, LC = Letramento científico, EC= Enculturação científica; ${ }^{(2)} \mathrm{N}=$ Número absoluto; ${ }^{(3)}$ Percentual relativo às produções acadêmicas em cada ano. ${ }^{(4)}$ Percentual relativo às produções acadêmicas no período de 2013 a 2017.

A partir dos dados da tabela 1, foi calculado a proporção de LC e EC em relação às 272 teses e dissertações que apresentaram apenas a expressão "Alfabetização Científica", resultando, respectivamente, nos percentuais de 16,5\% e 1,1\%.

Buscando compreender se há alguma especificidade desse tipo de produção quando comparada ao conjunto da produção científica fora do contexto da pósgraduação, foi feita uma simples busca ${ }^{26}$ no google acadêmico ${ }^{27}$, considerando o mesmo período de 2013 a 2017 (Tabela 2). Como resultado, foi visualizado um total

\footnotetext{
${ }^{25}$ Os campos de indexação referem-se a todos os campos de registro da produção para fins de indexação, tais como: título, resumo, palavras-chave, autor etc.

${ }^{26}$ Busca realizada no dia 21 de agosto de 2020. A busca foi feita sem incluir resultados de patentes ou citações, mas considerando qualquer idioma, mesmo sendo utilizados as expressões em português e entre aspas: "alfabetização científica", "letramento científico", "enculturação científica".

${ }^{27}$ O Google Scholar - Google Académico ou Acadêmico em português - é uma ferramenta de pesquisa do Google que permite pesquisar em trabalhos acadêmicos, literatura escolar, jornais de universidades e artigos variados. Lançado em Novembro de 2004 passou a oferecer buscas em língua Portuguesa em 10 de janeiro de 2006.
} 
de 7521 resultados, sendo 5844 para AC, 1600 para LC e 377 resultados para EC, representando uma proporção de resultados para LC e EC em relação à $A C$ de $22,2 \%$ e $6,5 \%$, respectivamente.

Tabela 2 Distribuição do conjunto de visualizações resultantes da busca de produções no google acadêmico, no período de 2013 a 2017, a partir do uso dos termos "alfabetização científica", "letramento científico" e "enculturação científica" no campo de busca.

\begin{tabular}{|c|c|c|c|c|c|c|c|c|c|c|c|c|c|c|c|c|c|}
\hline \multirow{3}{*}{$\begin{array}{c}\text { PRESENÇA DOS TERMOS } \\
\text { AC/LC/EC }\end{array}$} & \multicolumn{17}{|c|}{ ANO DE BUSCA } \\
\hline & \multicolumn{3}{|c|}{2013} & \multicolumn{3}{|c|}{2014} & \multicolumn{3}{|c|}{2015} & \multicolumn{3}{|c|}{2016} & \multicolumn{3}{|c|}{2017} & \multicolumn{2}{|c|}{ TOTAL } \\
\hline & $\mathrm{N}^{(2)}$ & $\%^{(3)}$ & $\%^{(4)}$ & $N^{(2)}$ & $\%^{(3)}$ & $\%^{(4)}$ & $\mathrm{N}^{(2)}$ & $\%^{(3)}$ & $\%^{(4)}$ & $\mathrm{N}^{(2)}$ & $\%^{(3)}$ & $\%^{(4)}$ & $\mathrm{N}^{(2)}$ & $\%^{(3)}$ & $\%^{(4)}$ & $\mathrm{N}^{(2)}$ & $\%^{(4)}$ \\
\hline$A C$ & 847 & $77,49 \%$ & $14,49 \%$ & 877 & $79,01 \%$ & $15,01 \%$ & 1160 & $77,70 \%$ & $19,85 \%$ & 1310 & $78,44 \%$ & $22,42 \%$ & 1650 & $76,57 \%$ & $28,23 \%$ & $5844^{\prime} 77,70 \%$ & $100,00 \%$ \\
\hline LC & 188 & $17,20 \%$ & $14,46 \%$ & 188 & $16,94 \%$ & $14,46 \%$ & 244 & $16,34 \%$ & $18,77 \%$ & 285 & $17,07 \%$ & $21,92 \%$ & 395 & $18,33 \%$ & $30,38 \%$ & $1300 " 17,28 \%$ & $100,00 \%$ \\
\hline EC & 58 & $5,31 \%$ & $15,38 \%$ & 45 & $4,05 \%$ & $11,94 \%$ & 89 & $5,96 \%$ & $23,61 \%$ & 75 & $4,49 \%$ & $19,89 \%$ & 110 & $5,10 \%$ & $29,18 \%$ & $3775,01 \%$ & $100,00 \%$ \\
\hline Total Geral & 1093 & $100,00 \%$ & $12,95 \%$ & 1110 & $100,00 \%$ & $14,50 \%$ & 1493 & $100,00 \%$ & $20,37 \%$ & 1670 & $100,00 \%$ & $23,77 \%$ & 2155 & $100,00 \%$ & $28,42 \%$ & $7521 \quad 100,00 \%$ & $100,00 \%$ \\
\hline
\end{tabular}

Esses resultados mostram um movimento similar entre a produção acadêmica e as visualizações do google acadêmico associadas a cada uma das expressões e dentro do mesmo período, apresentando um número maior de produções em AC, seguido das produções em LC e, por fim, das produções em EC, com pequenas diferenças nos percentuais de LC e EC em relação à $A C$ obtidos nos dois conjuntos de produção.

Observa-se, também, que a presença da expressão AC, de 2013 a 2017 aumentou em $100 \%$, enquanto, no mesmo período, a citação da expressão LC aumentou, comparativamente, ainda mais $(750 \%)$, o que também indica uma tendência de crescimento nas citações de LC, mas de forma muito mais intensa. No entanto, não é possível se certificar dessa tendência já que houve um movimento de estabilização nas citações de LC entre os anos de 2016 e 2017. Já em relação à EC, devido ao baixo número de citações de EC no período analisado, não foi possível reconhecer nenhuma tendência.

Esses resultados sugerem que a presença das expressões "enculturação científica" e "letramento científico" ainda não se mostra tão recorrente na produção acadêmica de teses e dissertações quando comparada à expressão "alfabetização científica". 


\subsection{Identificação do corpus documental da pesquisa e reconhecimento do total de produção em AC no período de 2013 a 2017}

Para a identificação do corpus documental da pesquisa, foi feita a análise de conteúdo dos 272 resumos que contemplaram a expressão $A C$ e outros 4 contemplando tanto $\mathrm{AC}$ quanto $\mathrm{LC}$, conforme apresentado na tabela 1 e discutido no item 6.1, totalizando 276 teses e dissertações. A análise de conteúdo teve como objetivo reconhecer possíveis apropriações da temática da AC organizadas em categorias, disponibilizando, a partir delas, critérios de exclusões ou inclusão, de forma a definir o nosso corpus documental da pesquisa.

No Quadro 2 são apresentadas as categorias identificadas no conjunto dos 276 resumos de teses e dissertações.

Quadro 2 Categorias de apropriação da alfabetização científica (AC) identificadas na análise dos resumos recuperados do Banco de Teses e Dissertações da CAPES e que se constituíram como critérios de inclusão para a definição do corpus documental da pesquisa.

\begin{tabular}{|c|c|}
\hline TIPO DE APROPRIAÇÃO & CATEGORIAS DE APROPRIAÇÃO DA ALFABETIZAÇÃO CIENTÍFICA (AC) IDENTIFICADAS NOS RESUMOS \\
\hline & ANALISA UM ASPECTO OU FAZ UMA PROPOSTA QUE FAVORECE OU PROMOVE A AC \\
DIRETA & ANALISA A APROPRIAÇÃO DA AC POR PARTE DE PROFESSORES, ALUNOS OU OUTROS SUJEITOS \\
& ANALISA UM ASPECTO OU FAZ UMA PROPOSTA BASEADA NOS PRESSUPOSTOS DA AC \\
ANALISA UM ASPECTO NO QUAL A AC SE MOSTRA NECESSÁRIA
\end{tabular}

Como resultado dessa análise, observou-se que todo o conjunto dos 276 resumos expressavam algum tipo de apropriação da AC nas pesquisas descritas, 0 que fez com que esse conjunto completo fosse selecionado como o nosso corpus documental, identificado como o conjunto de teses e dissertações defendidas no Brasil , no período de 2013 a 2017, e que mostraram algum tipo de apropriação da AC em suas pesquisas.

Mesmo as 4 produções (resumos 36, 40, 125 e 200, presentes no anexo B desta dissertação), que contemplam tanto $A C$ como $L C$, foram incorporadas, pois foram reconhecidas algumas categorias de apropriação da $A C$ apresentadas no quadro 2.

A distribuição, por ano, da produção relacionada ao corpus documental da pesquisa é apresentada na Tabela 3. 
Tabela 3 Distribuição, por ano de defesa, do conjunto de 276 teses e dissertações, defendidas no Brasil no período de 2013 a 2017, que mostraram se apropriar da alfabetização científica em sua pesquisa e que constitui o corpus documental da pesquisa.

\begin{tabular}{|c|c|c|c|c|c|c|c|c|c|c|c|c|c|c|c|c|c|c|}
\hline \multirow{3}{*}{ TEMÁTICA APROPRIADA ${ }^{(1)}$} & \multicolumn{18}{|c|}{ ANO DE DEFESA } \\
\hline & \multicolumn{3}{|c|}{2013} & \multicolumn{3}{|c|}{2014} & \multicolumn{3}{|c|}{2015} & \multicolumn{3}{|c|}{2016} & \multicolumn{3}{|c|}{2017} & \multicolumn{3}{|c|}{ TOTAL } \\
\hline & $\mathrm{N}^{(2)}$ & $\%^{(3)}$ & $\%^{(4)}$ & $\mathrm{N}^{(2)}$ & $\%^{(3)}$ & $\%^{(4)}$ & $\mathrm{N}^{(2)}$ & $\%^{(3)}$ & $\%^{(4)}$ & $\mathrm{N}^{(2)}$ & $\%^{(3)}$ & $\%^{(4)}$ & $\mathrm{N}^{(2)}$ & $\%^{(3)}$ & $\%^{(4)}$ & $\mathrm{N}^{(2)}$ & $\%^{(3)}$ & $\%^{(4)}$ \\
\hline$A C$ & 40 & $100,00 \%$ & $14,48 \%$ & 40 & $100,00 \%$ & $14,48 \%$ & 60 & $100,00 \%$ & $21,74 \%$ & 59 & $100,00 \%$ & $21,38 \%$ & 77 & $100,00 \%$ & $27,92 \%$ & 276 & $100,00 \%$ & $100,00 \%$ \\
\hline
\end{tabular}

${ }^{(1)} \mathrm{AC}=$ Alfabetização científica, ${ }^{(2)} \mathrm{N}=$ Número absoluto; ${ }^{(3)}$ Percentual relativo à produção em $\mathrm{AC}$ em cada ano. ${ }^{(4)}$ Percentual relativo à produção em $\mathrm{AC}$ no período de 2013 a 2017.

A partir da análise dos dados disponibilizados na Tabela 3, é possível reconhecer uma tendência de aumento na produção de pesquisas que se apropriam da AC, com movimentos de estabilidade entre os anos de 2013 e 2014 e entre os anos de 2015 e 2016, sendo observado um crescimento de $92,50 \%$ no número destas produções. No entanto, para reconhecer se este aumento é devido a uma maior apropriação da AC na área de Ensino de Ciências, foi proposta uma comparação com o percentual de crescimento no número de pesquisas na área de Ensino de Ciências, área na qual 70,29\% da produção em AC analisada mostrou estar associada (ver item 6.3.2.1 desta dissertação).

$\mathrm{Na}$ tabela 4 estão sistematizados os dados referentes à produção na área de Ensino. Como já esperado, é observado um aumento no número de produções nessa área no período analisado, com uma ampliação de 203 (17,6\%) entre os anos de 2013 e 2014; $283(20,8 \%)$ entre os anos de 2014 e 2015; 242 (14,7\%) entre os anos de 2015 e 2016; e 288 (15,3\%) entre os anos de 2016 e 2017.

Tabela 4 Distribuição, por ano de defesa, do conjunto de 276 teses e dissertações, defendidas no Brasil no período de 2013 a 2017, na área de Ensino.

\begin{tabular}{|c|c|c|c|c|c|c|c|c|c|c|c|}
\hline \multirow{3}{*}{ ÁREA DO CONHECIMENTO } & \multicolumn{11}{|c|}{ 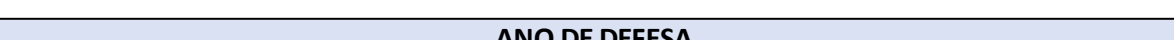 } \\
\hline & \multicolumn{2}{|c|}{2012} & \multicolumn{2}{|c|}{2014} & \multicolumn{2}{|c|}{ AIN U D } & \multicolumn{2}{|c|}{$\frac{\text { DETCSA }}{2016}$} & \multicolumn{2}{|c|}{2017} & TOTAI \\
\hline & (1) & 2013 & $\frac{24}{(1)}$ & of (2) & (1) & 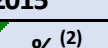 & $2(1)$ & 0 & 2 & 2018 & (1) \\
\hline = & 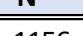 & 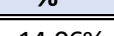 & 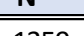 & 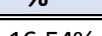 & 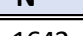 & 10 & 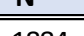 & $=0$ & 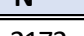 & $=0$ & " \\
\hline
\end{tabular}

A análise dos dados permite reconhecer a presença de uma ampliação entre $14 \%$ a $21 \%$ nessa produção, ano após ano e uma tendência de crescimento na área, resultando num crescimento da produção, no período analisado, em $87,9 \%$, valor relativamente próximo ao observado (de 100\%) no crescimento das pesquisas em AC, o que sugere que o crescimento observado em AC não se configura como uma especificidade dessa produção, refletindo apenas o crescimento da produção na área de Ensino na qual 70,29\% da produção em AC se insere. 


\subsection{Caracterização do conjunto de teses e dissertações em alfabetização científica, defendidas no Brasil, no período de 2013 a 2017}

Neste item, é feita a caracterização das 276 produções que mostraram algum tipo de apropriação da AC, focalizando o contexto de produção, do tipo de produção, das pesquisas relacionadas à produção e, por fim, da apropriação de cada um dos três eixos estruturantes de alfabetização científica.

\subsubsection{Caracterização do contexto de produção}

Como primeiro passo para reconhecer as características do corpus documental da pesquisa, é preciso caracterizar o seu contexto de produção utilizando-se os descritores padrões utilizados pela CAPES na indexação da produção acadêmica (grande região, estado e instituição do ensino superior - IES)

\subsubsection{Caracterização por grande região e estado}

$\mathrm{Na}$ Tabela 5 são apresentados os dados relativos ao contexto de produção em termos da grande região e estado onde a produção está vinculada.

A partir da análise dos dados, observa-se produções em AC em todas as Grades regiões do Brasil, no período analisado, não sendo observada na Grande Região Norte a presença de produções em AC no ano de 2014. Também se observa a ausência desse tipo de produção nos estados do Maranhão, Piauí, Acre, Amapá e Rondônia.

Mais da metade de toda a produção nacional de teses e dissertações em AC, no período analisado, está concentrada na Grande Região Sudeste, representando $50,72 \%$ dessa produção, destacando-se o estado de São Paulo (25,72\%), seguido pelo Espírito Santo (11,59\%), Rio de Janeiro (9,42\%) e Minas Gerais (3,98\%). 
A Grande Região Sul foi a segunda que mais contribuiu para a produção acadêmica em AC no período analisado, destacando-se o Paraná (11,60\%) e o Rio Grande do Sul (9,78\%), sendo o Paraná o $2^{\circ}$ estado de maior produção nacional em AC, superando, com exceção de São Paulo, os demais estados do Sudeste.

A produção em AC mostrou estar mais localizada nessas duas Grandes Regiões, Sul e Sudeste, que concentram $75,36 \%$ da produção acadêmica em AC no período analisado.

Tabela 5 Caracterização por grande região e estado.

\begin{tabular}{|c|c|c|c|c|c|c|c|c|c|c|c|c|c|c|c|c|c|c|c|}
\hline \multirow{3}{*}{ GRANDE REGIÃO } & \multirow{3}{*}{ ESTADO } & \multicolumn{18}{|c|}{ ANO DE DEFESA } \\
\hline & & \multicolumn{3}{|c|}{2013} & \multicolumn{3}{|c|}{2014} & \multicolumn{3}{|c|}{2015} & \multicolumn{3}{|c|}{2016} & \multicolumn{3}{|c|}{2017} & \multicolumn{3}{|c|}{ TOTAL } \\
\hline & & $N^{(1)}$ & $\%^{(2)}$ & $\%^{(3)}$ & $\mathrm{N}^{(1)}$ & $\%^{(2)}$ & $\%{ }^{(3)}$ & $\mathrm{N}^{(1)}$ & $\%^{(2)}$ & $\%^{(3)}$ & $\mathrm{N}^{(1)}$ & $\%^{(2)}$ & $\%^{(3)}$ & $\mathrm{N}^{(1)}$ & $\%^{(2)}$ & $\%^{(3)}$ & $\mathrm{N}^{(1)}$ & $\%^{(2)}$ & $\%^{(3)}$ \\
\hline \multirow{4}{*}{ SUDESTE } & SP & 11 & $27,50 \%$ & $15,48 \%$ & 14 & $35,00 \%$ & $19,71 \%$ & 11 & $18,33 \%$ & $15,49 \%$ & 19 & $32,20 \%$ & $26,77 \%$ & 16 & $20,78 \%$ & $22,56 \%$ & 71 & $25,72 \%$ & $100,00 \%$ \\
\hline & ES & 5 & $12,50 \%$ & $15,61 \%$ & 8 & $20,00 \%$ & $24,99 \%$ & 7 & $11,67 \%$ & $21,87 \%$ & 4 & $6,78 \%$ & $12,51 \%$ & 8 & $10,39 \%$ & $25,02 \%$ & 32 & $11,59 \%$ & $100,00 \%$ \\
\hline & RJ & 6 & $15,00 \%$ & $23,05 \%$ & 1 & $2,50 \%$ & $3,84 \%$ & 9 & $15,00 \%$ & $34,61 \%$ & 5 & $8,47 \%$ & $19,24 \%$ & 5 & $6,49 \%$ & $19,25 \%$ & 26 & $9,42 \%$ & $100,00 \%$ \\
\hline & MG & 5 & $12,50 \%$ & $45,42 \%$ & 1 & $2,50 \%$ & $9,09 \%$ & 2 & $3,33 \%$ & $18,19 \%$ & 2 & $3,39 \%$ & $18,20 \%$ & 1 & $1,30 \%$ & $9,10 \%$ & 11 & $3,98 \%$ & $100,00 \%$ \\
\hline SUDESTE Total & & 27 & $67,50 \%$ & $19,27 \%$ & 24 & $60,00 \%$ & $17,13 \%$ & 29 & $48,33 \%$ & $20,71 \%$ & 30 & $50,85 \%$ & $21,44 \%$ & 30 & $38,96 \%$ & $21,45 \%$ & 140 & $50,72 \%$ & $100,00 \%$ \\
\hline \multirow{3}{*}{ SUL } & $P R$ & 3 & $7,50 \%$ & $9,36 \%$ & 3 & $7,50 \%$ & $9,37 \%$ & 9 & $15,00 \%$ & $28,12 \%$ & 9 & $15,25 \%$ & $28,13 \%$ & 8 & $10,39 \%$ & $25,02 \%$ & 32 & $11,60 \%$ & $100,00 \%$ \\
\hline & RS & 2 & $5,00 \%$ & $7,40 \%$ & 4 & $10,00 \%$ & $14,80 \%$ & 7 & $11,67 \%$ & $25,92 \%$ & 5 & $8,47 \%$ & $18,52 \%$ & 9 & $11,69 \%$ & $33,36 \%$ & 27 & $9,78 \%$ & $100,00 \%$ \\
\hline & SC & 2 & $5,00 \%$ & $22,20 \%$ & 2 & $5,00 \%$ & $22,21 \%$ & 1 & $1,67 \%$ & $11,11 \%$ & 2 & $3,39 \%$ & $22,23 \%$ & 2 & $2,60 \%$ & $22,24 \%$ & 9 & $3,26 \%$ & $100,00 \%$ \\
\hline SUL Total & & 7 & $17,50 \%$ & $10,28 \%$ & 9 & $22,50 \%$ & $13,23 \%$ & 17 & $28,33 \%$ & $24,99 \%$ & 16 & $27,12 \%$ & $23,54 \%$ & 19 & $24,68 \%$ & $27,96 \%$ & 68 & $24,64 \%$ & $100,00 \%$ \\
\hline \multirow{7}{*}{ NORDESTE } & BA & 1 & $2,50 \%$ & $7,68 \%$ & 1 & $2,50 \%$ & $7,69 \%$ & 4 & $6,67 \%$ & $30,76 \%$ & 2 & $3,39 \%$ & $15,39 \%$ & 5 & $6,49 \%$ & $38,49 \%$ & 13 & $4,71 \%$ & $100,00 \%$ \\
\hline & SE & 2 & $5,00 \%$ & $28,55 \%$ & 3 & $7,50 \%$ & $42,84 \%$ & - & $0,00 \%$ & $0,00 \%$ & - & $0,00 \%$ & $0,00 \%$ & 2 & $2,60 \%$ & $28,61 \%$ & 7 & $2,54 \%$ & $100,00 \%$ \\
\hline & $\mathrm{CE}$ & - & $0,00 \%$ & $0,00 \%$ & - & $0,00 \%$ & $0,00 \%$ & 3 & $5,00 \%$ & $49,98 \%$ & 2 & $3,39 \%$ & $33,34 \%$ & 1 & $1,30 \%$ & $16,68 \%$ & 6 & $2,17 \%$ & $100,00 \%$ \\
\hline & AL & - & $0,00 \%$ & $0,00 \%$ & 1 & $2,50 \%$ & $24,98 \%$ & - & $0,00 \%$ & $0,00 \%$ & 1 & $1,69 \%$ & $25,00 \%$ & 2 & $2,60 \%$ & $50,02 \%$ & 4 & $1,45 \%$ & $100,00 \%$ \\
\hline & $\mathrm{PE}$ & - & $0,00 \%$ & $0,00 \%$ & - & $0,00 \%$ & $0,00 \%$ & 2 & $3,33 \%$ & $49,98 \%$ & - & $0,00 \%$ & $0,00 \%$ & 2 & $2,60 \%$ & $50,02 \%$ & 4 & $1,45 \%$ & $100,00 \%$ \\
\hline & $\mathrm{RN}$ & - & $0,00 \%$ & $0,00 \%$ & - & $0,00 \%$ & $0,00 \%$ & - & $0,00 \%$ & $0,00 \%$ & 1 & $1,69 \%$ & $33,32 \%$ & 2 & $2,60 \%$ & $66,68 \%$ & 3 & $1,09 \%$ & $100,00 \%$ \\
\hline & PB & - & $0,00 \%$ & $0,00 \%$ & - & $0,00 \%$ & $0,00 \%$ & - & $0,00 \%$ & $0,00 \%$ & 1 & $1,69 \%$ & $100,00 \%$ & - & $0,00 \%$ & $0,00 \%$ & 1 & $0,36 \%$ & $100,00 \%$ \\
\hline \multirow[t]{2}{*}{ NORDESTE Total } & & 3 & $7,50 \%$ & $7,88 \%$ & 5 & $12,50 \%$ & $13,15 \%$ & 9 & $15,00 \%$ & $23,68 \%$ & 7 & $11,86 \%$ & $18,42 \%$ & 14 & $18,18 \%$ & $36,87 \%$ & 38 & $13,77 \%$ & $100,00 \%$ \\
\hline & AM & 2 & $5,00 \%$ & $28,54 \%$ & - & $0,00 \%$ & $0,00 \%$ & 1 & $1,67 \%$ & $14,28 \%$ & 1 & $1,69 \%$ & $14,29 \%$ & 3 & $3,90 \%$ & $42,89 \%$ & 7 & $2,54 \%$ & $100,00 \%$ \\
\hline \multirow{4}{*}{ NORTE } & PA & - & $0,00 \%$ & $0,00 \%$ & - & $0,00 \%$ & $0,00 \%$ & - & $0,00 \%$ & $0,00 \%$ & 1 & $1,69 \%$ & $24,99 \%$ & 3 & $3,90 \%$ & $75,01 \%$ & 4 & $1,45 \%$ & $100,00 \%$ \\
\hline & $\mathrm{RR}$ & - & $0,00 \%$ & $0,00 \%$ & - & $0,00 \%$ & $0,00 \%$ & 1 & $1,67 \%$ & $33,31 \%$ & - & $0,00 \%$ & $0,00 \%$ & 2 & $2,60 \%$ & $66,69 \%$ & 3 & $1,09 \%$ & $100,00 \%$ \\
\hline & Tо & - & $0,00 \%$ & $0,00 \%$ & - & $0,00 \%$ & $0,00 \%$ & 1 & $1,67 \%$ & $49,98 \%$ & - & $0,00 \%$ & $0,00 \%$ & 1 & $1,30 \%$ & $50,02 \%$ & 2 & $0,72 \%$ & $100,00 \%$ \\
\hline & RO & - & $0,00 \%$ & $0,00 \%$ & - & $0,00 \%$ & $0,00 \%$ & - & $0,00 \%$ & $0,00 \%$ & 1 & $1,69 \%$ & $100,00 \%$ & - & $0,00 \%$ & $0,00 \%$ & 1 & $0,36 \%$ & $100,00 \%$ \\
\hline \multirow[t]{2}{*}{ NORTE Total } & & 2 & $5,00 \%$ & $11,75 \%$ & & $0,00 \%$ & $0,00 \%$ & 3 & $5,00 \%$ & $17,64 \%$ & 3 & $5,08 \%$ & $17,65 \%$ & 9 & $11,69 \%$ & $52,97 \%$ & 17 & $6,16 \%$ & $100,00 \%$ \\
\hline & GO & - & $0,00 \%$ & $0,00 \%$ & 2 & $5,00 \%$ & $19,98 \%$ & 1 & $1,67 \%$ & $10,00 \%$ & 3 & $5,08 \%$ & $30,00 \%$ & 4 & $5,19 \%$ & $40,02 \%$ & 10 & $3,62 \%$ & $100,00 \%$ \\
\hline \multirow[t]{2}{*}{ CENTRO-OESTE } & MS & - & $0,00 \%$ & $0,00 \%$ & - & $0,00 \%$ & $0,00 \%$ & 1 & $1,67 \%$ & $49,98 \%$ & - & $0,00 \%$ & $0,00 \%$ & 1 & $1,30 \%$ & $50,02 \%$ & 2 & $0,72 \%$ & $100,00 \%$ \\
\hline & MT & 1 & $2,50 \%$ & $100,00 \%$ & - & $0,00 \%$ & $0,00 \%$ & - & $0,00 \%$ & $0,00 \%$ & - & $0,00 \%$ & $0,00 \%$ & - & $0,00 \%$ & $0,00 \%$ & 1 & $0,36 \%$ & $100,00 \%$ \\
\hline CENTRO-OESTE Total & & 1 & $2,50 \%$ & $7,68 \%$ & 2 & $5,00 \%$ & $15,37 \%$ & 2 & $3,33 \%$ & $15,38 \%$ & 3 & $5,08 \%$ & $23,08 \%$ & 5 & $6,49 \%$ & $38,49 \%$ & 13 & $4,71 \%$ & $100,00 \%$ \\
\hline Total Geral & & $40 \quad 1$ & $100,00 \%$ & $14,48 \%$ & 40 & $100,00 \%$ & $14,48 \%$ & 60 & $100,00 \%$ & $21,74 \%$ & 59 & $100,00 \%$ & $21,38 \%$ & 77 & $100,00 \%$ & $27,92 \%$ & 276 & $100,00 \%$ & $100,00 \%$ \\
\hline
\end{tabular}

Uma forma de compreender melhor esse contexto de produção é observar a produção dentro da área de Ensino, na qual 70,29\% da produção em AC mostrou estar inserida.

Assim, analisando os dados da Tabela 6, que sistematiza os dados de produção no período de 2013 a 2017 na área de Ensino, percebe-se que alguns dados são muito similares àqueles apresentados na Tabela 5, indicando que algumas características do contexto de produção do corpus documental da pesquisa não se apresenta como algo particular e específico desse tipo de produção, configurando-se mais como um reflexo do contexto de produção da área de Ensino na qual 70,29\% da produção em AC se situa. 
Tabela 6 Distribuição, por grande região e estado, de toda a produção de teses e dissertações da área de Ensino.

\begin{tabular}{|c|c|c|c|}
\hline \multirow{3}{*}{ GRANDE REGIÃO } & \multirow{3}{*}{ ESTADO } & \multicolumn{2}{|c|}{ PERÍODO } \\
\hline & & \multicolumn{2}{|c|}{ 2013-2017 } \\
\hline & & $\mathrm{N}^{(1)}$ & $\%^{(2)}$ \\
\hline \multirow{4}{*}{ SUDESTE } & SP & 1866 & $22,72 \%$ \\
\hline & RJ & 939 & $11,43 \%$ \\
\hline & MG & 418 & $5,09 \%$ \\
\hline & ES & 248 & $3,02 \%$ \\
\hline SUDESTE Total & & 3471 & $42,26 \%$ \\
\hline \multirow{3}{*}{ SUL } & RS & 1249 & $15,21 \%$ \\
\hline & PR & 773 & $9,41 \%$ \\
\hline & SC & 238 & $2,90 \%$ \\
\hline SUL Total & & 2260 & $27,52 \%$ \\
\hline \multirow{8}{*}{ NORDESTE } & BA & 355 & $4,32 \%$ \\
\hline & PE & 288 & $3,51 \%$ \\
\hline & $\mathrm{RN}$ & 170 & $2,07 \%$ \\
\hline & SE & 142 & $1,73 \%$ \\
\hline & $\mathrm{AL}$ & 130 & $1,58 \%$ \\
\hline & PB & 114 & $1,39 \%$ \\
\hline & CE & 94 & $1,14 \%$ \\
\hline & MA & 4 & $0,05 \%$ \\
\hline NORDESTE Total & & 1297 & $15,79 \%$ \\
\hline \multirow{4}{*}{ CENTRO-OESTE } & GO & 287 & $3,49 \%$ \\
\hline & MS & 175 & $2,13 \%$ \\
\hline & MT & 112 & $1,36 \%$ \\
\hline & DF & 91 & $1,11 \%$ \\
\hline CENTRO-OESTE Total & & 665 & $8,10 \%$ \\
\hline \multirow{4}{*}{ NORTE } & PA & 278 & $3,39 \%$ \\
\hline & AM & 165 & $2,01 \%$ \\
\hline & $\mathrm{RR}$ & 61 & $0,74 \%$ \\
\hline & $A C$ & 16 & $0,19 \%$ \\
\hline NORTE Total & & 520 & $6,33 \%$ \\
\hline Total Geral & & 8213 & $100,00 \%$ \\
\hline
\end{tabular}

Como pode ser observado na Tabela 6, 69,78\% da produção da área de Ensino de situa nas regiões Sul e Sudeste e os estado de São Paulo concentra a maior parte dessa produção $(22,72 \%)$, apresentando, portanto, dados muito similares aos da Tabela 5. No entanto, pode-se perceber algumas particularidades comparando as tabelas 5 e 6 . O estado do Espírito Santo, por exemplo, apresenta um volume de produções em AC muito significativo, mesmo contribuindo pouco, em termos quantitativos, para a área de Ensino, o que acaba representando uma particularidade do contexto de produção em AC nesse período.

As produções em AC no estado do Paraná também devem ser destacadas como uma particularidade dessa produção, já que representa o segundo estado com maior produção em AC no período, mesmo sendo o estado do Paraná apenas o quarto em número de produções de teses e dissertações na área de Ensino. Também se observa uma inversão, quando se compara os dados das regiões norte e centro-oeste nas tabelas 5 e 6, mostrando que a produção em Ensino na região norte, mesmo 
sendo menor do que no Centro-oeste, ainda assim possui uma maior produção em AC.

\subsubsection{Caracterização por Instituição de Ensino Superior (IES)}

$\mathrm{Na}$ Tabela 7 são apresentados os dados relativos ao contexto de produção em termos da Instituição de Ensino Superior (IES) associada à produção em AC analisada.

A maior produção em AC, verificada nos estados de São Paulo, Espírito Santo e Paraná, mostrou estar associada a uma produção concentrada em IES específicas em cada estado. Em São Paulo, a USP concentra sozinha 11,59\% da produção em AC no período analisado. No Espírito Santo, o IFES contribui com 10,14\%, enquanto no Paraná, a produção está mais concentrada na UTFPR, com 6,88\%. 
Tabela 7 Caracterização da produção acadêmica em AC por Instituição de Ensino Superior.

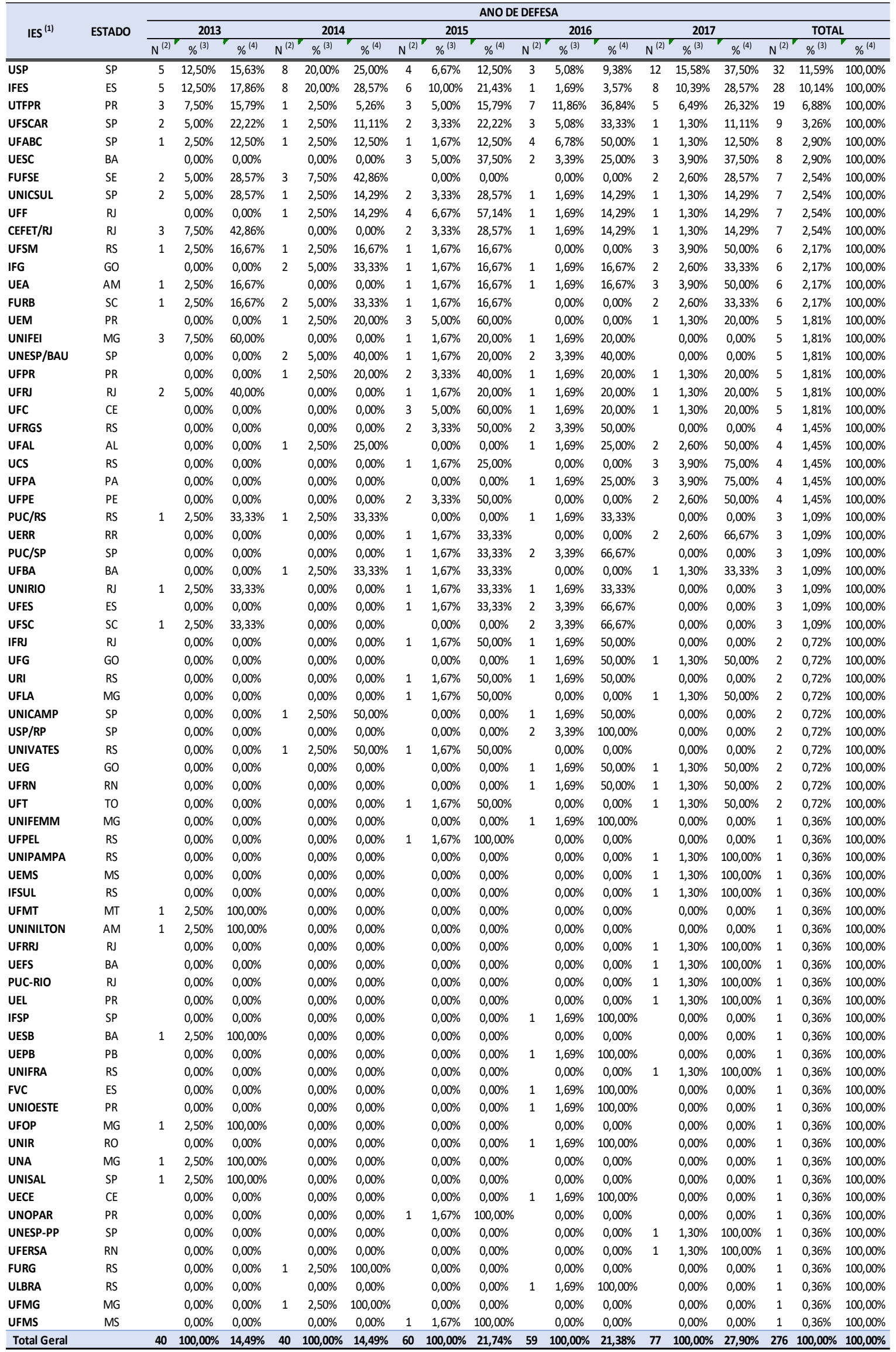

(1) Siglas das IES. (2) $\mathrm{N}=$ Número absoluto; ${ }^{(3)}$ Percentual relativo à produção em $\mathrm{AC}$ em cada ano. ${ }^{(4)}$ Percentual relativo à produção em $\mathrm{AC}$ no período de 2013 Siglas 


\subsubsection{Caracterização da natureza da produção}

Esse segundo nível de caracterização do nosso corpus documental da pesquisa focaliza a identificação da Grande área do conhecimento a que se refere à produção, à área do conhecimento ao qual está inserido os Programas de PósGraduação associados às produções e, por último, ao tipo de produção e grau acadêmico.

\subsubsection{Caracterização por grande área e área do conhecimento}

A Tabela 9 apresenta os dados relativos à caracterização da produção em AC por grande área do conhecimento a que se refere a produção e à área do conhecimento a que se insere os Programas de Pós-Graduação onde a produção foi concebida.

Analisando os dados da Tabela 9 observa-se que a produção em AC, no período analisado, está concentrada na área de Ensino (70,29\%) e Educação (18,48\%) que, juntas, respondem por $88,77 \%$ da produção em AC, estando a temática da AC mais associada ao campo da Educação e Ensino e ao campo das Ciências Naturais (Física, Química, Biologia), com menor inserção em outras grandes áreas, do conhecimento, tais como Comunicação e Engenharias.

Tabela 8 Caracterização da produção acadêmica em AC por grande área e área do conhecimento.

\begin{tabular}{|c|c|c|c|c|c|c|c|c|c|c|c|c|c|c|c|c|c|c|c|}
\hline \multirow{3}{*}{$\begin{array}{l}\text { GRANDE ÁREA DO } \\
\text { CONHECIMENTO }{ }^{(1)}\end{array}$} & \multirow{3}{*}{ ÁREA DO CONHECIMENTO ${ }^{(2)}$} & \multicolumn{18}{|c|}{ ANO DE DEFESA } \\
\hline & & \multicolumn{3}{|c|}{2013} & \multicolumn{3}{|c|}{2014} & \multicolumn{3}{|c|}{2015} & \multicolumn{3}{|c|}{2016} & \multicolumn{3}{|c|}{2017} & \multicolumn{3}{|c|}{ TOTAL } \\
\hline & & $\mathrm{N}^{(3)^{n}}$ & $\%^{(4)}$ & $\%^{(5)}$ & $N^{(3)^{\prime}}$ & $\%^{(4)}$ & $\%^{(5)}$ & $\mathrm{N}^{(3)^{n}}$ & $\%^{(4)}$ & $\%{ }^{(5)}$ & $\mathrm{N}^{(3)^{\prime}}$ & $\%^{(4)}$ & $\%{ }^{(5)}$ & $N^{(3)^{n}}$ & $\%^{(4)}$ & $\%{ }^{(5)}$ & $\mathrm{N}^{(3)^{\prime}}$ & $\%^{(4)}$ & $\%^{(5)}$ \\
\hline \multirow{4}{*}{ MULTIDISCIPLINAR } & ENSINO & 29 & $72,50 \%$ & $14,93 \%$ & 33 & $82,50 \%$ & $17,00 \%$ & 41 & $68,33 \%$ & $21,13 \%$ & 37 & $62,71 \%$ & $19,08 \%$ & 54 & $70,13 \%$ & $27,86 \%$ & 194 & 70,29\% & $100,00 \%$ \\
\hline & INTERDISCIPLINAR & 2 & $5,00 \%$ & $66,63 \%$ & - & $0,00 \%$ & $0,00 \%$ & - & $0,00 \%$ & $0,00 \%$ & 1 & $1,69 \%$ & $33,37 \%$ & - & $0,00 \%$ & $0,00 \%$ & 3 & $1,09 \%$ & $100,00 \%$ \\
\hline & CIÊNCIAS AMBIENTAIS & - & $0,00 \%$ & $0,00 \%$ & - & $0,00 \%$ & $0,00 \%$ & 1 & $1,67 \%$ & $49,98 \%$ & & $0,00 \%$ & $0,00 \%$ & 1 & $1,30 \%$ & $50,02 \%$ & 2 & $0,72 \%$ & $100,00 \%$ \\
\hline & BIOTECNOLOGIA & - & $0,00 \%$ & $0,00 \%$ & - & $0,00 \%$ & $0,00 \%$ & 1 & $1,67 \%$ & $49,99 \%$ & 1 & $1,69 \%$ & $50,01 \%$ & - & $0,00 \%$ & $0,00 \%$ & 2 & $0,72 \%$ & $100,00 \%$ \\
\hline CIÊNCIAS HUMANAS & EDUCAÇÃO & 6 & $15,00 \%$ & $11,75 \%$ & 5 & $12,50 \%$ & $9,80 \%$ & 12 & $20,00 \%$ & $23,52 \%$ & 13 & $22,03 \%$ & $25,50 \%$ & 15 & $19,48 \%$ & $29,43 \%$ & 51 & $18,48 \%$ & $100,00 \%$ \\
\hline \multirow{2}{*}{ CIÊNCIAS EXATAS E DA TERRA } & FÍSICA & - & $0,00 \%$ & $0,00 \%$ & - & $0,00 \%$ & $0,00 \%$ & 3 & $5,00 \%$ & $27,26 \%$ & 4 & $6,78 \%$ & $36,36 \%$ & 4 & $5,19 \%$ & $36,38 \%$ & 11 & $3,99 \%$ & $100,00 \%$ \\
\hline & QUÍMICA & - & $0,00 \%$ & $0,00 \%$ & 1 & $2,50 \%$ & $19,98 \%$ & 1 & $1,67 \%$ & $19,99 \%$ & 2 & $3,39 \%$ & $40,01 \%$ & 1 & $1,30 \%$ & $20,01 \%$ & 5 & $1,81 \%$ & $100,00 \%$ \\
\hline \multirow{3}{*}{ CIÊNCIAS BIOLÓGICAS } & BIOFÍSICA & 1 & $2,50 \%$ & $33,30 \%$ & - & $0,00 \%$ & $0,00 \%$ & 1 & $1,67 \%$ & $33,33 \%$ & - & $0,00 \%$ & $0,00 \%$ & 1 & $1,30 \%$ & $33,37 \%$ & 3 & $1,09 \%$ & $100,00 \%$ \\
\hline & BIOLOGIA GERAL & 2 & $5,00 \%$ & $100,00 \%$ & - & $0,00 \%$ & $0,00 \%$ & - & $0,00 \%$ & $0,00 \%$ & - & $0,00 \%$ & $0,00 \%$ & - & $0,00 \%$ & $0,00 \%$ & 2 & $0,72 \%$ & $100,00 \%$ \\
\hline & ZOOLOGIA & - & $0,00 \%$ & $0,00 \%$ & - & $0,00 \%$ & $0,00 \%$ & - & $0,00 \%$ & $0,00 \%$ & 1 & $1,69 \%$ & $100,00 \%$ & - & $0,00 \%$ & $0,00 \%$ & 1 & $0,36 \%$ & $100,00 \%$ \\
\hline ENGENHARIAS & ENGENHARIA SANITÁRIA & - & $0,00 \%$ & $0,00 \%$ & - & $0,00 \%$ & $0,00 \%$ & - & $0,00 \%$ & $0,00 \%$ & - & $0,00 \%$ & $0,00 \%$ & 1 & $1,30 \%$ & $100,00 \%$ & 1 & $0,36 \%$ & $100,00 \%$ \\
\hline CIÊNCIAS SOCIAIS APLICADAS & COMUNICAÇÃO & - & $0,00 \%$ & $0,00 \%$ & 1 & $2,50 \%$ & $100,00 \%$ & - & $0,00 \%$ & $0,00 \%$ & - & $0,00 \%$ & $0,00 \%$ & - & $0,00 \%$ & $0,00 \%$ & 1 & $0,36 \%$ & $100,00 \%$ \\
\hline Total Geral & & 40 & $100,00 \%$ & $14,48 \%$ & $40 \quad 1$ & $100,00 \%$ & $14,48 \%$ & 60 & $100,00 \%$ & $21,74 \%$ & 59 & $100,00 \%$ & $21,38 \%$ & 77 & $100,00 \%$ & $27,92 \%$ & 276 & $100,00 \%$ & $100,00 \%$ \\
\hline
\end{tabular}


Essa grande inserção na área de Ensino faz com que as características específicas da produção em AC estejam muito associadas às características da Área de Ensino na qual está inserida, como já discutido anteriormente em algumas caracterizações das teses e dissertações em AC realizadas.

\subsubsection{Caracterização por tipo de produção e grau acadêmico}

Os dados relativos à caracterização da produção em AC por tipo de produção e grau acadêmico estão organizados na Tabela 10.

Tabela 9 Caracterização da produção acadêmica em AC por tipo de produção e grau acadêmico.

\begin{tabular}{|c|c|c|c|c|c|c|c|c|c|c|c|c|c|c|c|c|c|c|c|}
\hline \multirow{3}{*}{ GRAU ACADÊMICO } & \multirow{3}{*}{ TIPO DE PRODUÇÃO } & \multicolumn{18}{|c|}{ ANO DE DEFESA } \\
\hline & & \multicolumn{3}{|c|}{2013} & \multicolumn{3}{|c|}{2014} & \multicolumn{3}{|c|}{2015} & \multicolumn{3}{|c|}{2016} & \multicolumn{3}{|c|}{2017} & \multicolumn{3}{|c|}{ TOTAL } \\
\hline & & $\overline{N^{(1)}}$ & $\%^{(2)}$ & $\%^{(3)}$ & $\mathrm{N}^{(1)}$ & $\%^{(2)}$ & $\%^{(3)}$ & $\mathrm{N}^{(1)}$ & $\%^{(2)}$ & $\%^{(3)}$ & $\mathrm{N}^{(1)^{\prime}}$ & $\%^{(2)}$ & $\%^{(3)}$ & $\mathrm{N}^{(1)}$ & $\%^{(2)}$ & $\%^{(3)}$ & $N^{(1)^{\prime}}$ & $\%^{(2)}$ & $\%^{(3)}$ \\
\hline MESTRADO PROFISSIONAL & DISSERTAÇÃO & 15 & $37,50 \%$ & $11,52 \%$ & 15 & $37,50 \%$ & $11,53 \%$ & 26 & $43,33 \%$ & $19,99 \%$ & 29 & $49,15 \%$ & $22,31 \%$ & 45 & $58,44 \%$ & $34,64 \%$ & 130 & $47,11 \%$ & $100,00 \%$ \\
\hline MESTRADO & DISSERTAÇÃO & 19 & $47,50 \%$ & $17,57 \%$ & 19 & $47,50 \%$ & $17,58 \%$ & 23 & $38,33 \%$ & $21,29 \%$ & 23 & $38,98 \%$ & $21,31 \%$ & 24 & $31,17 \%$ & $22,24 \%$ & 108 & $39,13 \%$ & $100,00 \%$ \\
\hline DOUTORADO & TESE & 6 & $15,00 \%$ & $15,77 \%$ & 6 & $15,00 \%$ & $15,78 \%$ & 11 & $18,33 \%$ & $28,95 \%$ & 7 & $11,86 \%$ & $18,43 \%$ & 8 & $10,39 \%$ & $21,07 \%$ & 38 & $13,77 \%$ & $100,00 \%$ \\
\hline Total Geral & & 40 & $100,00 \%$ & $14,48 \%$ & 40 & $100,00 \%$ & $14,48 \%$ & 60 & $100,00 \%$ & $21,74 \%$ & 59 & $100,00 \%$ & $21,38 \%$ & 77 & $100,00 \%$ & $27,92 \%$ & 276 & $100,00 \%$ & $100,00 \%$ \\
\hline
\end{tabular}

Analisando os dados da Tabela 10, observa-se que a produção em AC está associada tanto a teses de doutorado quando a dissertações de mestrado acadêmico e mestrado profissional, com uma representação mais deste último $(47,11 \%)$, sendo as dissertações de mestrado (acadêmico e profissional) responsável por $86,23 \%$ da produção em AC no período analisado.

Também é observado uma tendência de aumento nas produções em AC nos mestrados profissionais e um movimento mais tímido de crescimento no mestrado acadêmico. No doutorado, não é possível ver uma tendência clara, havendo uma contribuição menor, quando comparado com o mestrado.

Isso pode ser compreendido de forma mais clara, quando se observa o total de produção na área de Ensino no qual se insere $70,29 \%$ da produção em AC (Tabela 11). 
Tabela 10 Caracterização, por grau acadêmico, de toda produção acadêmica na área de Ensino.

\begin{tabular}{|c|c|c|c|c|c|c|c|c|c|c|c|c|c|c|c|c|c|c|}
\hline \multirow{3}{*}{ GRAU ACADÊMICO } & \multicolumn{18}{|c|}{ ANO DE DEFESA } \\
\hline & \multicolumn{3}{|c|}{2013} & \multicolumn{3}{|c|}{2014} & \multicolumn{3}{|c|}{2015} & \multicolumn{3}{|c|}{2016} & \multicolumn{3}{|c|}{2017} & \multicolumn{3}{|c|}{ TOTAL } \\
\hline & $N^{(1)}$ & $\%^{(2)}$ & $\%^{(3)}$ & $\mathrm{N}^{(1)}$ & $\%^{(2)}$ & $\%^{(3)}$ & $N^{(1)}$ & $\%^{(2)}$ & $\%^{(3)}$ & $\mathrm{N}^{(1)}$ & $\%^{(2)}$ & $\%^{(3)}$ & $\mathrm{N}^{(1)}$ & $\%^{(2)}$ & $\%^{(3)}$ & $\mathrm{N}^{(1)}$ & $\%^{(2)}$ & $\%^{(3)}$ \\
\hline MESTRADO PROFISSIONAL & 496 & $42,91 \%$ & $13,13 \%$ & 616 & $45,33 \%$ & $16,30 \%$ & 758 & $46,16 \%$ & $20,06 \%$ & 857 & $45,49 \%$ & $22,68 \%$ & 1051 & $48,39 \%$ & $27,82 \%$ & 3778 & $46,00 \%$ & $100,00 \%$ \\
\hline MESTRADO & 482 & $41,70 \%$ & $14,96 \%$ & 533 & $39,22 \%$ & $16,54 \%$ & 627 & $38,19 \%$ & $19,45 \%$ & 764 & $40,55 \%$ & $23,70 \%$ & 817 & $37,62 \%$ & $25,35 \%$ & 3223 & $39,24 \%$ & $100,00 \%$ \\
\hline DOUTORADO & 178 & $15,40 \%$ & $14,69 \%$ & 210 & $15,45 \%$ & $17,33 \%$ & 257 & $15,65 \%$ & $21,20 \%$ & 263 & $13,96 \%$ & $21,70 \%$ & 304 & $14,00 \%$ & $25,08 \%$ & 1212 & $14,76 \%$ & $100,00 \%$ \\
\hline Total Geral & 1156 & $100,00 \%$ & $14,08 \%$ & 1359 & $100,00 \%$ & $16,55 \%$ & 1642 & $100,00 \%$ & $19,99 \%$ & 1884 & $100,00 \%$ & $22,94 \%$ & 2172 & $100,00 \%$ & $26,45 \%$ & 8213 & $100,00 \%$ & $100,00 \%$ \\
\hline
\end{tabular}

Comparando os dados das Tabelas 10 e 11, observa-se um padrão similar da produção em $A C$ e da produção na área de ensino, em termos do grau acadêmico e tipo de produção, o que sugere que as características da produção em AC apenas espelham as características da produção na área de Ensino, na qual 70,29\% da produção em AC encontra-se inserida. Assim, não são observadas particularidades das teses e dissertações em AC em termos do tipo de produção e grau acadêmico.

\subsection{Identificação das características mais internas e particulares das pesquisas em AC}

Neste item, é realizada a identificação das características mais internas e particulares de cada uma das pesquisas presentes no conjunto de teses e dissertações em AC, explicitadas no corpo textual dos resumos analisados.

Como discutido na metodologia, a identificação das características das pesquisas em termos apenas do que é claramente explicitado no corpo textual dos resumos é devido à própria limitação da estrutura do resumo e da restrição de informações, dificultando a identificação dessas características para além do que é efetivamente explicitado no texto do resumo. Assim, ao assumir apenas as informações explicitadas textualmente nos resumos, a nossa caracterização acaba por expressar a própria visão dos autores sobre sua pesquisa e a forma como a caracterizam, não havendo, portanto, um movimento nosso de atribuição de características e significados. 


\subsubsection{Identificação das abordagens utilizadas nas pesquisas}

$\mathrm{Na}$ tabela 12 estão organizados os dados relativos às abordagens das pesquisas explicitadas nos resumos das teses e dissertações em AC analisados.

Tabela 11 Abordagens da pesquisa explicitadas nos resumos de teses e dissertações em AC.

\begin{tabular}{|c|c|c|c|c|c|c|c|c|c|c|c|c|c|c|c|c|c|c|}
\hline \multirow{3}{*}{ ABORDAGEM DE PESQUISA } & \multicolumn{18}{|c|}{ ANO DE DEFESA } \\
\hline & \multicolumn{3}{|c|}{2013} & \multicolumn{3}{|c|}{2014} & \multicolumn{3}{|c|}{2015} & \multicolumn{3}{|c|}{2016} & \multicolumn{3}{|c|}{2017} & \multicolumn{3}{|c|}{ TOTAL } \\
\hline & $\mathrm{N}^{(2)}$ & $\%^{(3)}$ & $\%^{(4)}$ & $\mathrm{N}^{(2)}$ & $\%^{(3)}$ & $\%^{(4)}$ & $\mathrm{N}^{(2)}$ & $\%^{(3)}$ & $\%^{(4)}$ & $\mathrm{N}^{(2)}$ & $\%^{(3)}$ & $\%^{(4)}$ & $\mathrm{N}^{(2)}$ & $\%^{(3)}$ & $\%^{(4)}$ & $\mathrm{N}^{(2)}$ & $\%^{(3)}$ & $\%^{(4)}$ \\
\hline QUALITATIVA & 20 & $50,00 \%$ & $1,80 \%$ & 18 & $45,00 \%$ & $5,52 \%$ & 29 & $48,33 \%$ & $16,41 \%$ & 26 & $44,07 \%$ & $23,35 \%$ & 42 & $54,55 \%$ & $52,92 \%$ & 135 & $48,91 \%$ & $100,00 \%$ \\
\hline NÃO EXPLICITADA ${ }^{(1)}$ & 19 & $47,50 \%$ & $2,92 \%$ & 20 & $50,00 \%$ & $7,39 \%$ & 24 & $40,00 \%$ & $15,57 \%$ & 29 & $49,15 \%$ & $28,66 \%$ & 33 & $42,86 \%$ & $45,46 \%$ & 125 & $45,29 \%$ & $100,00 \%$ \\
\hline QUALI-QUANTI & 1 & $2,50 \%$ & $2,51 \%$ & 2 & $5,00 \%$ & $6,97 \%$ & 6 & $10,00 \%$ & $43,72 \%$ & 3 & $5,08 \%$ & $30,34 \%$ & 1 & $1,30 \%$ & $16,46 \%$ & 13 & $4,71 \%$ & $100,00 \%$ \\
\hline QUANTITATIVA & & $0,00 \%$ & $0,00 \%$ & & $0,00 \%$ & $0,00 \%$ & 1 & $1,67 \%$ & $23,93 \%$ & 1 & $1,69 \%$ & $35,80 \%$ & 1 & $1,30 \%$ & $40,27 \%$ & 3 & $1,09 \%$ & $100,00 \%$ \\
\hline Total Geral & 40 & $100,00 \%$ & $2,30 \%$ & 40 & $100,00 \%$ & $6,34 \%$ & 60 & $100,00 \%$ & $17,28 \%$ & 59 & $100,00 \%$ & $26,19 \%$ & 77 & $100,00 \%$ & $47,89 \%$ & 276 & $100,00 \%$ & $100,00 \%$ \\
\hline
\end{tabular}

(1) $\mathrm{N}=$ Número absoluto. (2) Percentual relativo à produção em cada ano. ${ }^{(3)}$ Percentual relativo à produção no período de 2013 a 2017.

É possível reconhecer que a abordagem qualitativa se apresenta como a abordagem de pesquisa mais recorrente $(48,91 \%)$ nas pesquisas em $A C$, mesmo sendo identificado um alto índice de não explicitação (45,29\%) da abordagem da pesquisa nos resumos analisados. Também é verificado um percentual significativo de abordagens que mesclam as dimensões qualitativa e quantitativa $(4,71 \%)$ e apenas um pequeno percentual de pesquisas que se apropriam de uma abordagem puramente quantitativa $(1,09 \%)$.

De maneira geral, observa-se que a maioria das pesquisas não recorrem à quantificação, baseando-se muito no reconhecimento de categorias definidas tanto a priori, como também a posteriori.

\subsubsection{Identificação de outras características das pesquisas}

As características de pesquisa explicitadas do conjunto de resumos analisados são apresentadas na Tabela 16. 
Tabela 12 Características das pesquisas explicitadas nos resumos analisados.

\begin{tabular}{|c|c|c|c|c|c|c|c|c|c|c|c|c|c|c|c|c|c|c|}
\hline \multirow{3}{*}{$\begin{array}{c}\text { CARACTERÍSTICAS DAS } \\
\text { PESQUISAS EXPLICITADAS NOS } \\
\text { RESUMOS }\end{array}$} & \multicolumn{18}{|c|}{ ANO DE DEFESA } \\
\hline & \multicolumn{3}{|c|}{2013} & \multicolumn{3}{|c|}{2014} & \multicolumn{3}{|c|}{2015} & \multicolumn{3}{|c|}{2016} & \multicolumn{3}{|c|}{2017} & \multicolumn{3}{|c|}{ TOTAL } \\
\hline & $N^{(2)}$ & $\%^{(3)}$ & $\%^{(4)}$ & $N^{(2)}$ & $\%^{(3)}$ & $\%^{4}$ & $\mathrm{~N}^{(2)}$ & $\%^{(3)}$ & $\%^{(4)}$ & $N^{(2)}$ & $\%^{(3)}$ & $\%^{(4)}$ & $\mathrm{N}^{(2)}$ & $\%^{(3)}$ & $\%^{(4)}$ & $N^{(2)}$ & $\%^{(3)}$ & $\%^{(4)}$ \\
\hline Não explicitada ${ }^{(1)}$ & 24 & $59,30 \%$ & $2,39 \%$ & 28 & $60,56 \%$ & $6,67 \%$ & 39 & $57,38 \%$ & $16,82 \%$ & 39 & $63,94 \%$ & $26,34 \%$ & 51 & $61,14 \%$ & $47,78 \%$ & 181 & $61,09 \%$ & $100,00 \%$ \\
\hline Pesquisa de estudo de caso & 7 & $8,86 \%$ & $1,66 \%$ & 7 & $15,18 \%$ & $7,79 \%$ & 8 & $11,26 \%$ & $15,39 \%$ & 8 & $12,71 \%$ & $24,41 \%$ & 12 & $13,93 \%$ & $50,75 \%$ & 42 & $13,10 \%$ & $100,00 \%$ \\
\hline Pesquisa descritiva & 3 & $5,65 \%$ & $1,99 \%$ & 1 & $2,89 \%$ & $2,78 \%$ & 5 & $7,95 \%$ & $20,38 \%$ & 2 & $2,96 \%$ & $10,67 \%$ & 8 & $9,39 \%$ & $64,17 \%$ & 19 & $6,98 \%$ & $100,00 \%$ \\
\hline Pesquisa-ação & 1 & $1,75 \%$ & $0,74 \%$ & 3 & $6,88 \%$ & $7,96 \%$ & 7 & $9,96 \%$ & $30,68 \%$ & 3 & $4,62 \%$ & $20,00 \%$ & 4 & $4,95 \%$ & $40,62 \%$ & 18 & $5,81 \%$ & $100,00 \%$ \\
\hline Pesquisa bibliográfica & 4 & $5,84 \%$ & $4,74 \%$ & 1 & $1,64 \%$ & $3,64 \%$ & 3 & $4,55 \%$ & $26,88 \%$ & 1 & $1,53 \%$ & $12,73 \%$ & 3 & $3,30 \%$ & $52,02 \%$ & 12 & $3,03 \%$ & $100,00 \%$ \\
\hline Pesquisa exploratória & 1 & $0,88 \%$ & $0,68 \%$ & 1 & $2,14 \%$ & $4,50 \%$ & 2 & $2,89 \%$ & $16,20 \%$ & 5 & $7,85 \%$ & $61,82 \%$ & 1 & $1,12 \%$ & $16,80 \%$ & 10 & $3,20 \%$ & $100,00 \%$ \\
\hline Pesquisa de campo & 3 & $3,12 \%$ & $3,79 \%$ & 1 & $2,32 \%$ & $7,69 \%$ & 2 & $3,01 \%$ & $26,63 \%$ & 3 & $4,98 \%$ & $61,89 \%$ & & $0,00 \%$ & $0,00 \%$ & 9 & $2,03 \%$ & $100,00 \%$ \\
\hline Pesquisa teórico-empírica & 3 & $6,23 \%$ & $12,75 \%$ & 3 & $6,77 \%$ & $37,85 \%$ & & $0,00 \%$ & $0,00 \%$ & & $0,00 \%$ & $0,00 \%$ & 1 & $1,25 \%$ & $49,40 \%$ & 7 & $1,20 \%$ & $100,00 \%$ \\
\hline Pesquisa documental & 1 & $4,09 \%$ & $4,58 \%$ & 1 & $1,64 \%$ & $5,02 \%$ & 1 & $1,46 \%$ & $11,89 \%$ & & $0,00 \%$ & $0,00 \%$ & 3 & $3,62 \%$ & $78,52 \%$ & 6 & $2,20 \%$ & $100,00 \%$ \\
\hline pesquisa interpretativa & & $0,00 \%$ & $0,00 \%$ & & $0,00 \%$ & $0,00 \%$ & 1 & $1,54 \%$ & $21,99 \%$ & 1 & $1,41 \%$ & $28,30 \%$ & 1 & $1,31 \%$ & $49,71 \%$ & 3 & $1,25 \%$ & $100,00 \%$ \\
\hline Pesquisa teórica & 1 & $4,28 \%$ & $100,00 \%$ & & $0,00 \%$ & $0,00 \%$ & & $0,00 \%$ & $0,00 \%$ & & $0,00 \%$ & $0,00 \%$ & & $0,00 \%$ & $0,00 \%$ & 1 & $0,11 \%$ & $100,00 \%$ \\
\hline Total Geral & 48 & $100,00 \%$ & $2,46 \%$ & 46 & $100,00 \%$ & $6,73 \%$ & 68 & $100,00 \%$ & $17,91 \%$ & 62 & $100,00 \%$ & $25,16 \%$ & 84 & $100,00 \%$ & $47,74 \%$ & 308 & $100,00 \%$ & $100,00 \%$ \\
\hline
\end{tabular}

É possível identificar, a partir dos dados da Tabela 13, que a maior parte das produções $(61,09 \%)$ não caracterizam a pesquisa desenvolvida, deixando implícita suas características, limitando-se em descrever os passos metodológicos, o que é natural quando se trata de resumos.

No entanto, mesmo com uma baixa explicitação é possível reconhecer algumas identidades assumidas pelas pesquisas de forma mais significativa, como é o caso da pesquisa de estudos de caso $(16,10 \%)$, pesquisa descritiva(6,98\%), pesquisa-ação $(5,81 \%)$, pesquisa bibliográfica $(3,03 \%)$ e pesquisa exploratória $(3,20 \%)$.

A presença de estudos de caso reflete a tendência já verificada do uso de uma abordagem qualitativa que, geralmente, se baseia em um número menor de sistemas de análise ou em apenas um único sistema de análise, que é onde se localiza o estudo de caso, buscando aprofundar compreensões de processos dentro de um único sistema de interesse.

Também é observado um equilíbrio interessante entre as pesquisas descritivas ${ }^{28}$ e pesquisas do tipo pesquisa-ação, na qual geralmente envolve sujeitos que se apresentam de forma ativa na pesquisa, compartilhando com o pesquisador, as ações nas atividades relacionadas à pesquisa.

De maneira geral, a identidade da pesquisa, assumida como teórica, documental, bibliográfica e descritiva, explicita um caráter mais teórico da apropriação da alfabetização científica na pesquisa, enquanto que as pesquisas de estudo de

\footnotetext{
${ }^{28}$ Em geral, pesquisas de caráter mais descritivo não contemplam interações com sujeitos.
} 
caso, pesquisa-ação, interpretativas, teórico-empíricas e de campo sinalizam para uma identidade de pesquisa mais relacionada a ações envolvendo sujeitos e processos em contextos naturais da realidade educacional. $O$ fato dos dados disponíveis apontarem a presença dessas duas identidades de pesquisa, de forma tão equilibrada, nos impossibilita de tentar forçar algum tipo caracterização geral para a produção em AC analisada, assumindo as pesquisas desenvolvidas mais associada a uma ou outra identidade, o que levaria a uma generalização precipitada e a um possível distanciamento da identidade real desse conjunto de pesquisas, que, em nossa visão, poderia ser efetivamente identificada apenas por meio da análise do texto completo do conjunto dessas produções.

\subsection{Caracterização das pesquisas em termos da apropriação de cada um dos três eixos estruturantes da alfabetização científica}

Neste item, as pesquisas em AC são caracterizadas de forma mais aprofundada, a partir da análise da apropriação de cada um dos três eixos estruturantes de alfabetização científica: conhecimento científico, contextualização e natureza da ciência.

\subsubsection{Análise da apropriação do eixo "Conhecimento Científico" nas pesquisas em AC}

Os dados relativos à caracterização dos diferentes tipos de organização do conhecimento pelas pesquisas em AC analisadas estão sistematizados na Tabela 14. É possível observar um percentual significativo $(15,16 \%)$ na apropriação da interdisciplinaridade pela produção em AC analisada, mostrando também um movimento de crescimento da presença da dimensão interdisciplinar na produção em AC no período analisado. 
Tabela 13 Caracterização dos diferentes tipos de organização do conhecimento identificados nas pesquisas em AC.

\begin{tabular}{|c|c|c|c|c|c|c|c|c|c|c|c|c|c|c|c|c|c|c|}
\hline \multirow{3}{*}{$\begin{array}{l}\text { TIPO DE ORGANIZAÇÃO DO } \\
\text { CONHECIMENTO CITADO NOS } \\
\text { RESUMOS ANALISADOS }\end{array}$} & \multicolumn{18}{|c|}{ ANO DE DEFESA } \\
\hline & \multicolumn{3}{|c|}{2013} & \multicolumn{3}{|c|}{2014} & \multicolumn{3}{|c|}{2015} & \multicolumn{3}{|c|}{2016} & \multicolumn{3}{|c|}{2017} & \multicolumn{3}{|c|}{ TOTAL } \\
\hline & $\mathrm{N}^{(2)}$ & $\%^{(3)}$ & $\%^{(4)}$ & $\mathrm{N}^{(2)}$ & $\%^{(3)}$ & $\%^{(4)}$ & $\mathrm{N}^{(2)}$ & $\%^{(3)}$ & $\%^{(4)}$ & $\mathrm{N}^{(2)}$ & $\%^{(3)}$ & $\%^{(4)}$ & $\mathrm{N}^{(2)}$ & $\%^{(3)}$ & $\%^{(4)}$ & $\mathrm{N}^{(2)}$ & $\%^{(3)}$ & $\%^{(4)}$ \\
\hline DISCIPLINAR OU NÃO EXPLICITADA ${ }^{(1)}$ & 35 & $88,42 \%$ & $2,44 \%$ & 32 & $79,16 \%$ & $6,13 \%$ & 53 & $86,95 \%$ & $18,51 \%$ & 48 & $80,12 \%$ & $25,12 \%$ & 64 & $81,57 \%$ & 47,80\% & 232 & $82,14 \%$ & $100,00 \%$ \\
\hline INTERDISCIPLINAR & 4 & $10,90 \%$ & $1,63 \%$ & 4 & $9,15 \%$ & $3,83 \%$ & 7 & $10,19 \%$ & $11,76 \%$ & 10 & $18,35 \%$ & $31,17 \%$ & 13 & $16,26 \%$ & $51,61 \%$ & 38 & $15,16 \%$ & $100,00 \%$ \\
\hline TRANSDISCIPLINAR & 1 & $0,68 \%$ & $1,06 \%$ & 3 & $6,56 \%$ & $28,67 \%$ & 2 & $2,85 \%$ & $34,34 \%$ & & $0,00 \%$ & $0,00 \%$ & 1 & $1,08 \%$ & $35,93 \%$ & 7 & $1,45 \%$ & $100,00 \%$ \\
\hline MULTIDISCIPLINAR & & $0,00 \%$ & $0,00 \%$ & 2 & $5,14 \%$ & $26,29 \%$ & & $0,00 \%$ & $0,00 \%$ & 1 & $1,53 \%$ & $31,68 \%$ & 1 & $1,08 \%$ & $42,03 \%$ & 4 & $1,24 \%$ & $100,00 \%$ \\
\hline Total Geral & 40 & $100,00 \%$ & $2,27 \%$ & 41 & $100,00 \%$ & $6,36 \%$ & 62 & $100,00 \%$ & $17,49 \%$ & 59 & $100,00 \%$ & $25,75 \%$ & 79 & $100,00 \%$ & $48,13 \%$ & 281 & $100,00 \%$ & $100,00 \%$ \\
\hline
\end{tabular}

Interessante notar também o fato do percentual de produções envolvendo transdisciplinaridade ser superior ao percentual de produções de caráter multidisciplinar ${ }^{29}$. Essas pesquisas nas quais a transdisciplinaridade mostra-se presente estão associadas a estudos envolvendo a discussão sobre pensamento complexo (MORIN, 2015) e complexidade (Resumos 6, 64 e 89), apropriando-se como referencial, de conceitos desenvolvidos por Edgard Morin ${ }^{30}$, como também da teoria da práxis (GADOTTI, 1998) relacionada à obra de Paulo Freire ${ }^{31}$ (resumo 52). Nos resumos 46, 105 e 203, a ideia de transdisciplinaridade se mistura com a de interdisciplinaridade, não sendo possível o reconhecimento da forma específica de como a transdisciplinaridade é compreendida ou apropriada pela pesquisa.

Em relação à dimensão interdisciplinar presentes na produção em $\mathrm{AC}$ analisada, um maior aprofundamento sobre essa produção possibilita-nos reconhecer que das 38 produções que explicitaram a dimensão interdisciplinar, 24 (63,16\%) explicitaram os temas interdisciplinares trabalhados, conforme mostrado na Tabela 15.

\footnotetext{
29 Deve-se levar em conta que muitos trabalhos multidisciplinares não se autointitulam dessa forma, levando a não explicitação do caráter multidisciplinar nos resumos analisados. Assim, o percentual real desses trabalhos deve ser maior do que o identificado e apresentado na Tabela 14.

30 Edgar Morin é considerado um dos principais pensadores contemporâneos e um dos principais teóricos do campo de estudos da complexidade, que inclui perspectivas anglo-saxônicas e latinas. Sua abordagem é conhecida como "pensamento complexo" ou "paradigma da complexidade". Morin não se identifica como "teórico da complexidade" nem pretende limitar seus estudos às chamadas "ciências da complexidade". Ele distingue entre perspectivas restritas, limitadas, e amplas ou generalizadas da complexidade.
}

${ }^{31}$ Paulo Freire 
Analisando os dados da Tabela 15, observa-se um grande percentual de temas associados à temática ambiental mais geral, mostrando a relevância da temática ambiental nessa produção e sua relação com o caráter interdisciplinar observado.

Tabela 14 Caracterização dos temas interdisciplinares identificados nas pesquisas em AC.

\begin{tabular}{|c|c|c|}
\hline TEMÁtICA GERAL* & TEMA INTERDISCIPLINAR & Total \\
\hline \multirow{12}{*}{ TEMÁTICA (AMBIENTAL) } & "HORTA ESCOLAR & 2 \\
\hline & EDUCAÇ̄̃O AMBIENTAL & 2 \\
\hline & (CONJUNTO DE 3 TEMAS) SANEAMENTO BÁSICO, SUSTENTABILIDADE, EDUCAÇÃO AMBIENTAL & 1 \\
\hline & AMBIENTE: LXO & 1 \\
\hline & DESCARTE CORRETO DE MEDICAMENTOS & 1 \\
\hline & ECOLOGIA & 1 \\
\hline & ÁGUA & 1 \\
\hline & AMBIENTES RECIFAIS & 1 \\
\hline & ÓTICA AMBIENTAL DA LOCALIDADE ESCOLAR & 1 \\
\hline & (CONJUNTO DE 6 TEMAS) contaminação do solo, lixo, contaminaç̃o da água, saneamento básico, contaminação do ar, efeitos da contaminação no corpo humano e elementos qu & 1 \\
\hline & A IMPORTÂNCIA DA ÁGUA & 1 \\
\hline & DESCARGAS ATMOSFÉRICAS & 1 \\
\hline TEMÁTICA (NÃO ESPECIFICADA) & TEMA NÃO ESPECIFICADO & 14 \\
\hline \multirow{3}{*}{ TEMÁTICA (CIÊNCIA DOS ALIMENTOS) } & ALIMENTAÇÃO HUMANA-AC & 1 \\
\hline & SEGURANÇA ALIMENTAR & 1 \\
\hline & RÓTULOS DE ALIMENTOS & 1 \\
\hline TEMÁTICA (FÍ́SICA/BIOLOGIA) & ASTROBIOLOGIA** & 2 \\
\hline TEMÁTICA (CIÊNCIA GERAL) & NANOCIÊNCIA E NANOTECNOLOGIA & 1 \\
\hline TEMÁtICA (CIÊNCIAS FARMACÊUTICAS) & PLANTAS MEDICINAIS & 1 \\
\hline TEMÁTICA (FÍSICA/ARTES) & REPRESENTAÇÖES ASTRONÔMICAS EM ESPAÇOS INTERDISCIPLINARES & 1 \\
\hline TEMÁTICA BIOLÓGICA & VIDA & 1 \\
\hline TEMÁTICA (COMUNICAÇÃO SOCIAL) & COMUNICAÇÃO CIENTIFICA & 1 \\
\hline Total Geral & & 38 \\
\hline
\end{tabular}

\subsubsection{Análise da apropriação do eixo "Natureza da Ciência"32 nas pesquisas em AC}

Na tabela 16, as categorias de apropriação do eixo "Natureza da Ciência" pelas Pesquisas em alfabetização científica (AC).

Tabela 15 Caracterização da apropriação do eixo "Natureza da Ciência" pelas pesquisas em AC.

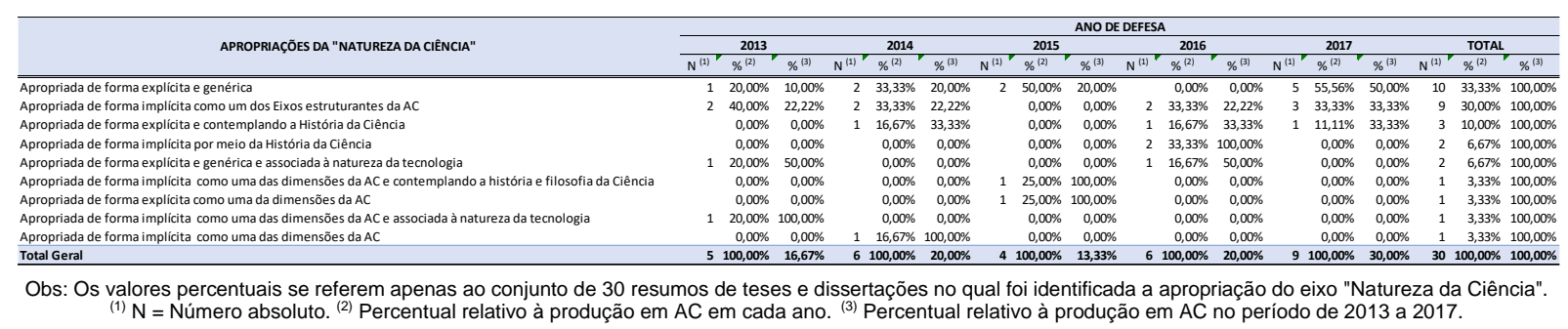

${ }^{32}$ A natureza da Ciência é entendida como um conjunto de elementos que tratam da construção, estabelecimento e organização do conhecimento científico. Isto pode abranger desde questões internas, tais como método científico e relação entre experimento e teoria, até outras externas, como a influência de elementos sociais, culturais, religiosos e políticos na aceitação ou rejeição de ideias científicas (MOURA, 2014). 
A apropriação do eixo "natureza da Ciência" mostrou-se restrita a apenas 30 produções, sendo considerada tanto apropriações explícitas, quando a natureza da ciência se mostra explicitada no resumo, como também apropriações implícitas, quando se verifica apenas citações a dimensões ou eixos estruturantes da AC que, conceitualmente, contemplam a "Natureza da Ciência".

Dos 30 resumos, verifica-se que 16 deles (53,33\%) mostraram explicitamente algum tipo de apropriação da Natureza da Ciência, que se apresentou nos resumos de forma genérica (33,33\%), contemplando a História da Ciência (10,00\%), associada à "Natureza da Tecnologia (6,67\%) e também como uma das dimensões da $A C$, $(3,33 \%)$.

Um outro tipo de apropriação, caracterizada por nós como implícita, foi observada em 14 resumos (46,67\%), considerando a presença da Natureza da Ciência, de forma implícita, como um dos eixos estruturantes da alfabetização científica $(30,00 \%)$, como uma das dimensões da $A C$ e associada à Natureza da Tecnologia (3,33\%), e apenas como uma das dimensões da $\mathrm{AC}(3,33 \%)$.

É importante destacar que, dos 176 resumos analisados, apenas 30 mostraram algum tipo de apropriação da "Natureza da Ciência", o que representa apenas 10,87\% da produção analisada. No entanto, esse baixo valor não pode ser visto como uma baixa apropriação da "Natureza da Ciência", pois assim como estabelecemos que a natureza da Ciência está implícita quando se discute história da Ciência e as dimensões e eixos estruturantes da AC, é bem possível que, em alguns trabalhos a natureza da Ciência esteja implícita na expressão alfabetização científica, não sendo uma opção do autor explicitá-la textualmente no corpo do resumo. Também é possível que a natureza da ciência esteja vinculada a características de processos de investigação científica destacados nas pesquisas em AC, sem, contudo, assumi-las explicitamente à Natureza da Ciência.

No entanto, a pouca incidência de estudos relacionados à História da Ciência $(16,67 \%)$ no conjunto analisado, e que assumimos integralmente como parte das pesquisas que se apropriaram do eixo "Natureza da Ciência", sugere que realmente o eixo "Natureza da Ciência", pelo menos em sua dimensão histórica, tem sido pouco privilegiado nas pesquisas em AC. Mais restrito ainda se encontra a dimensão 
filosófica da "Natureza da Ciência", observada estar presente em apenas um dos resumos (Resumo 69 do Anexo B).

Para além da discussão sobre a representatividade da presença da Natureza da Ciência" (NC) na produção analisada, a forma de apropriação da NC mostrou situar-se na história da Ciência e nas dimensões e eixos estruturantes da AC, sendo que a designação a partir do uso dos termos "dimensões" ou "eixos estruturantes" está relacionada ao fato de cada um desses termos estarem associados a referenciais teóricos que sistematizam o conceito da alfabetização científica de forma particular e com linguagens próprias.

Também é possível observar que o caráter externalista da Ciência ${ }^{33}$ acaba ficando restrito às suas implicações na atualidade e vinculado e expresso de forma mais efetiva a partir da contextualização. Já o caráter internalista se restringiria às especificidades da Ciência expressa em seu conteúdo e em seu método.

\subsubsection{Análise da apropriação do eixo "contextualização" nas pesquisas em AC}

$\mathrm{Na}$ Tabela 17 são apresentados os dados obtidos a partir da análise da apropriação do eixo "contextualização" nas pesquisas em AC.

Tabela 16 Caracterização da apropriação do eixo "Contextualização" pelas pesquisas em AC.

\begin{tabular}{|c|c|c|c|c|c|c|c|c|c|c|c|c|c|c|c|c|c|c|}
\hline \multirow{3}{*}{ PERSPECTIVA DE CONTEXTUALIZAÇÃO* } & \multicolumn{18}{|c|}{ ANO DE DEFESA } \\
\hline & \multicolumn{4}{|c|}{2013} & \multicolumn{2}{|c|}{2014} & \multicolumn{3}{|c|}{2015} & \multicolumn{3}{|c|}{2016} & \multicolumn{3}{|c|}{2017} & \multicolumn{3}{|c|}{ TOTAL } \\
\hline & $\mathrm{N}^{* *}$ & $\% * * *$ & $\% * * * *$ & $\mathrm{~N}^{* *}$ & $\%^{* * *}$ & $\% * * * *$ & $\mathrm{~N}^{* *}$ & $\%^{* * *}$ & $\% * * * *$ & $\mathrm{~N}^{* *}$ & $\% * * *$ & $\% * * * *$ & $\mathrm{~V}^{* *}$ & $\% * * *$ & $\%^{* * * *}$ & $\mathrm{~N}^{* *}$ & $\%^{* * *}$ & $\% * * * *$ \\
\hline Não explicitada ou ausente & 15 & $44,24 \%$ & $1,1,94 \%$ & 25 & (58,21\% & $7,36 \%$ & 32 & 47,48\% & $16,39 \%$ & 30 & 48,57\% & $23,65 \%$ & 46 & 55,47\% & 50,66\% & 148 & $52,20 \%$ & $10100,00 \%$ \\
\hline Cotidiano (COT) & 8 & $18,27 \%$ & $3,58 \%$ & & $0,00 \%$ & $0,00 \%$ & 5 & $6,61 \%$ & $10,21 \%$ & 10 & $16,73 \%$ & $36,47 \%$ & 10 & $12,17 \%$ & $49,74 \%$ & 33 & $11,66 \%$ & $100,00 \%$ \\
\hline Ciência, Tecnologia e Sociedade (CTS) & 10 & $23,34 \%$ & $5,18 \%$ & 3 & $6,44 \%$ & $4,13 \%$ & 7 & $10,15 \%$ & $17,75 \%$ & 7 & $11,53 \%$ & $28,45 \%$ & 8 & $9,61 \%$ & $44,49 \%$ & 35 & $10,30 \%$ & $100,00 \%$ \\
\hline Ciência, Tecnologia, Sociedade e Ambiente (CTSA) & 7 & $9,82 \%$ & $3,40 \%$ & 8 & $16,98 \%$ & $16,94 \%$ & 5 & $8,03 \%$ & $21,87 \%$ & 5 & $7,80 \%$ & $29,97 \%$ & 3 & $3,86 \%$ & $27,82 \%$ & 28 & $6,62 \%$ & $100,00 \%$ \\
\hline Educação Ambiental (EA) & & $0,00 \%$ & $0,00 \%$ & 3 & $5,89 \%$ & $6,16 \%$ & 4 & $6,05 \%$ & $17,27 \%$ & 2 & $2,89 \%$ & $11,64 \%$ & 7 & $8,59 \%$ & $64,93 \%$ & 16 & $6,31 \%$ & $100,00 \%$ \\
\hline Genérica & 1 & $1,48 \%$ & $0,67 \%$ & & $0,00 \%$ & $0,00 \%$ & 6 & $9,12 \%$ & $32,74 \%$ & 3 & $4,97 \%$ & $25,18 \%$ & 4 & $4,36 \%$ & $41,41 \%$ & 14 & $5,02 \%$ & $100,00 \%$ \\
\hline Aspectos, Temas ou Questões Sociocientíficas (QSC) & 1 & $1,90 \%$ & $1,47 \%$ & 3 & $5,85 \%$ & $13,10 \%$ & 2 & $3,38 \%$ & $20,64 \%$ & 5 & $7,52 \%$ & $64,78 \%$ & & $0,00 \%$ & $0,00 \%$ & 11 & $2,95 \%$ & $100,00 \%$ \\
\hline Aspectos, Temas ou Questões Socioambientais (QSA) & 1 & $0,95 \%$ & $0,86 \%$ & 2 & $4,43 \%$ & $11,51 \%$ & 2 & $2,65 \%$ & $18,84 \%$ & & $0,00 \%$ & $0,00 \%$ & 3 & $3,66 \%$ & $68,79 \%$ & 8 & $2,54 \%$ & $100,00 \%$ \\
\hline Aspectos, Temas ou Questões Socioculturais (QSC) & & $0,00 \%$ & $0,00 \%$ & & $0,00 \%$ & $0,00 \%$ & 1 & $1,29 \%$ & $17,65 \%$ & & $0,00 \%$ & $0,00 \%$ & 2 & $2,27 \%$ & $82,35 \%$ & 3 & $1,31 \%$ & $100,00 \%$ \\
\hline Saberes Populares (SP) & & $0,00 \%$ & $0,00 \%$ & 1 & $2,20 \%$ & $13,30 \%$ & 4 & $5,24 \%$ & $86,70 \%$ & & $0,00 \%$ & $0,00 \%$ & & $0,00 \%$ & $0,00 \%$ & 5 & $1,09 \%$ & $100,00 \%$ \\
\hline Total Geral & 43 & $100,00 \%$ & $2,29 \%$ & 45 & $100,00 \%$ & $6,60 \%$ & 68 & $100,00 \%$ & $18,01 \%$ & 621 & $100,00 \%$ & $25,42 \%$ & 83 & $100,00 \%$ & $47,68 \%$ & 301 & $100,00 \%$ & $100,00 \%$ \\
\hline
\end{tabular}

\footnotetext{
${ }^{33}$ Assunto discutido no item 4 desta monografia, focalizando a história da Ciência.
} 
A partir da análise dos dados da Tabela 17 observa-se, primeiramente, que há explicitação da contextualização em $47,80 \%$ da produção analisada, número muito superior ao observado para a Natureza da Ciência, sugerindo uma maior apropriação do eixo "contextualização" quando comparado ao eixo "Natureza da Ciência".

Do total analisado, a contextualização explorando o cotidiano (COT) e as relações Ciência, Tecnologia e Sociedade (CTS) figuram-se como as duas formas de contextualização mais presentes nos resumos analisados, correspondendo, respectivamente, a 11,66 e 10,30\%. Interessante observar que essas duas perspectivas de contextualização são as mais consolidadas historicamente, devido à CTS configurar-se tanto quanto um movimento, como uma perspectiva ou abordagem para o Ensino e que vem se ampliando no meio acadêmico e educacional, além do fato, também, da perspectiva CTS acabar assumindo para si as relações científicotecnológicas, estas normalmente associadas à perspectiva CTS de contextualização. Já o cotidiano, mesmo perdendo seu status de termo da moda, a partir do lançamento dos $\mathrm{PCNEM}^{34}$, que fortaleceu o termo contextualização, ainda se mostra bem presente, mostrando a força dessa perspectiva e das crenças associadas a ela de determinar um ensino mais eficaz.

Foi observada uma equiparidade entre o percentual de produções contendo relações CTSA (6,62\%) e Educação Ambiental (6,31\%), como também a observação de movimentos opostos dessas produções, no período de 2013 a 2017, com a diminuição da presença da contextualização CTSA e aumento da Educação Ambiental como elemento contextualizador. Esse comportamento oposto pode ser resultado de uma possível migração de trabalhos da área ou movimento CTSA para a área de Educação Ambiental, já que ambas possuem a dimensão ambiental como ponto de convergência.

Também, dentro da Seara ambiental, foi identificada a categoria "Aspectos, Temas ou Questões Socioambientais (QSA)" no eixo "contextualização", representando $2,54 \%$ da produção analisada, reforçando ainda mais a importância da temática ambiental na produção de teses e dissertações em AC.

\footnotetext{
${ }^{34}$ Parâmetros Currículares Nacionais do Ensino Médio.
} 


\section{Conclusão}

Neste item é explicitada uma "síntese conclusiva", buscando verificar até que ponto o conjunto de resultados obtidos conseguem responder a questão inicial de pesquisa e aos objetivos traçados, de forma a explicitar as reais contribuições do conhecimento produzido para a compreensão da dinâmica de produção de pesquisas envolvendo a temática da alfabetização científica, indicando, também, algumas lacunas que se mostraram relevantes e que poderiam ser consideradas para a complementação e aprofundamento desse estudo em pesquisas futuras relacionadas ao tema.

O conjunto de resultados obtidos nesta pesquisa permite fornecer algumas respostas à nossa questão de pesquisa: Quais eixos estruturantes estão mais evidenciados nas pesquisas sobre alfabetização científica publicadas no período de 2013 a 2017, e como se dá a apropriação desses eixos por essas pesquisas?

Buscando responder a esse questionamento, buscaremos sintetizar os principais resultados obtidos, de forma a evidenciar algumas características identificadas na produção analisada e que vão ao encontro de uma resposta à nossa problematização inicial.

Primeiramente, observou-se que as expressões "enculturação científica" e "letramento científico" ainda não se mostraram tão recorrentes na produção acadêmica de teses e dissertações quando comparadas à expressão "alfabetização científica". Em termos quantitativos, observou-se que a presença da expressão "alfabetização científica" nas produções acadêmicas em nível de pós-graduação mostrou ser muito superior à presença das expressões "letramento científico" e "enculturação científica”.

Todavia, essa característica não se configurou como uma particularidade da produção acadêmica de teses e dissertações em AC, já que proporções similares foram observadas em outros conjuntos de produção em AC não restritos à produção acadêmica, o que valida esse conjunto de teses e dissertações como um sistema representativo para reconhecimento de movimentos e tendências da produção científica em AC em outros conjuntos de produção de caráter mais geral, não restritos à produção acadêmica em nível de pós-graduação. 
Em termos da natureza da produção, $70,29 \%$ da produção em AC mostrou estar concentrada na área de Ensino, o que faz com que o contexto de produção e o tipo de produção dessas teses e dissertações sejam muito similares às dessa área, sendo observadas algumas poucas particularidades da produção em AC.

Em termos das características mais internas e particulares das pesquisas em AC, a abordagem qualitativa mostrou-se presente na maior parte da produção analisada, já que a maioria das pesquisas mostrou não recorrer à quantificação como abordagem metodológica em suas análises.

No que se refere às formas de apropriação do conhecimento científico como um dos eixos estruturantes da $\mathrm{AC}$, observou-se uma apropriação significativa do caráter interdisciplinar, estando este muito associado à presença de temáticas ambientais nas pesquisas desenvolvidas.

Em relação à apropriação do eixo "natureza da Ciência", identificou-se a presença explícita deste eixo em apenas $10,87 \%$ da produção analisada, sugerindo que o eixo "Natureza da Ciência" (NC), principalmente em sua dimensão histórica, tem sido pouco privilegiado nas pesquisas em AC, sendo observadas apropriações explícitas da NC - envolvendo citações genéricas e outras citações associadas à história da Ciência, à natureza da tecnologia e às dimensões da $\mathrm{AC}$ - como também apropriações implícitas da NC, incorporadas como um dos eixos estruturantes e dimensões da AC, como também associada à natureza da Tecnologia.

Já em relação à apropriação da "contextualização" como um dos eixos estruturantes da AC, o "cotidiano" e as relações "Ciência, Tecnologia e Sociedade (CTS)" foram as duas formas de contextualização mais recorrentes nos resumos analisados, sendo observados, também, alguns movimentos da produção, no período analisado, envolvendo a diminuição da presença da contextualização CTSA e o consequente aumento da Educação Ambiental como temática contextualizadora presente nas pesquisas em AC.

Os resultados obtidos nesse estudo possibilitaram a identificação de algumas características e apropriações das produções acadêmicas em $A C$ em relação à apropriação dos três diferentes eixos estruturantes da AC. No entanto, essa caracterização ainda se mostrou limitada, necessitando que sejam conduzidos outros estudos que possam ampliar essa análise para um período maior e para além dos resumos das produções em AC, assumindo o texto completo dessas produções 
acadêmicas como sistema de análise, o que possibilitará uma visão mais nítida dessa produção, principalmente em relação às tendências nas pesquisas em AC. 


\section{Referências}

ABD-EL-KHALICK, F.; LEDERMAN, N. G. The influence of history of Science courses on students' views of nature of science. Journal of Research in Science Teaching, v. 37, n. 10, p. 1057-1095, 2000. Disponível em: <http://citeseerx.ist.psu.edu/viewdoc/ download?doi=10.1.1.466.265\&rep=rep1\&type=pdf>. Acesso em: 21 ago. 2020.

ALLCHIN, D. Values in science: an educational perspective. Science \& Education, n. 8 , p. 1-12, 1999. Disponível em: <https://link.springer.com/content/pdf/ 10.1023/A:1008600230536.pdf >. Acesso em: 21 ago. 2020.

ALMEIDA, A. V.; FARIAS, C. R. O. A natureza da ciência na formação de professores: reflexões a partir de um curso de licenciatura em ciências biológicas. Investigações em Ensino de Ciências. v. 16, n. 3, p. 473-488. 2011. Disponível em: $<$ https://www.if.ufrgs.br/cref/ojs/index.php/ienci/article/view/222>. Acesso em: 21 ago. 2020.

ALVES, M. Conhecimento científico: sua valorização nas orientações curriculares e percepções de futuros professores do 1. CEB. 2013. $161 \mathrm{f}$. Dissertação (Mestrado) Faculdade de Psicologia e de Ciências da Educação, Universidade de Coimbra, Coimbra, Portugal. Disponível em: <https://estudogeral.sib.uc.pt/bitstream/10316/25394 /1/Tese\%20-\%20Marco\%20Aur\%C3\%A9lio\%20Alves\%20repositorium.pdf >. Acesso em: 21 ago. 2020.

ANDRÉ, M. E. D. A. (Org.) Formação de professores no Brasil (1990-1998). Brasília: MEC/Inep/Comped, 2002. 364 p. (Série Estado do Conhecimento, 6). Disponível em: <http://portal.inep.gov.br/documents/186968/484330/Forma\%C3\% A7\%C3\%A3o+de+professores+no+Brasil+\%281990-1998\%29/74844bc9-4864-48a9 -94be-092b494294fc?version=1.3>. Acesso em: 21 ago. 2020.

ARAÚJO, U. F. Temas Transversais e a estratégia de projetos. São Paulo: Moderna, 2003.

BALDINATO, J. O.; PORTO, P. A. Variações da história da ciência no ensino de ciências. In: VI Encontro Nacional de Pesquisa em Educação em Ciências, 2007, 
Florianópolis. Anais... Florianópolis: ABRAPEC, 2007. Disponível em: < $\underline{\text { http:// }}$ abrapecnet.org.br/atas enpec/vienpec/CR2/p1023.pdf>. Acesso em: 21 ago. 2020.

BARBEROUSSE, A.; KISTLER, M.; LUDEIG, P. A filosofia das ciências do século XX. Instituto Piaget, Flammarion, 2000. p. 160-163. 253 p.

BARDIN, L. Análise de Conteúdo. Tradução de Luís Antero Reto e Augusto Pinheiro. Lisboa: Edições 70, 2011. 279p.

BAUER, M. W.; GASKELL, G. Pesquisa qualitativa com texto, imagem e som: um manual prático. Petrópolis, RJ: Vozes, 2003. 516p.

BERNSTEIN, B. A estruturação do discurso pedagógico: classe, códigos e controle. Petrópolis: Vozes, 1996.

BRZEZINSKI, I.; GARRIDO, E. Formação de Profissionais da Educação (2003 2010). Brasília: MEC/Inep, 2014. (Série Estado do Conhecimento ,16).

BYBEE, R. W. Achieving scientific literacy. The Science Teacher., v. 62, n. 7, p. 2833, 1995.

CAILLOT, M., (1996). La théorie de la transposition didactique est-elle transposable? In: RAISKY, C., CAILLOT, M. Au-delá des didactiques, le didactique. Débats autour de concepts fédérateurs. Paris/Bruxelles: De Boeck \& Larcier, p. 19-35.

CARVALHO, G. S. A transposição didática e o ensino da biologia. In: CALDEIRA, A. M. A.; ARAUJO, E. S. N. N.(Orgs). Introdução à Didática da Biologia. São Paulo: Escrituras. 2009. p.34-57.

CARVALHO, G. S.; CLÉMENT, P. Projecto "Educação em biologia, educação para a saúde e educação ambiental para uma melhor cidadania": análise de manuais escolares e concepções de professores de 19 países (europeus, africanos e do próximo oriente). Revista Brasileira de Pesquisa em Educação em Ciências, v. 7, n. 2, 16 fev. 2011. Disponível em: <https://periodicos.ufmg.br/index.php/rbpec/article /view/4036>. Acesso em: 21 ago. 2020. 
CHEVALLARD, Y. La Transposición didactica: del Saber Sábio al saber enseñado. Buenos Aires: Aique editores, 1991.

CIRANI, C. B. S.; CAMPANARIO, M. A.; SILVA, H. H. M. A evolução do ensino da pós-graduação senso estrito no Brasil: análise exploratória e proposições para pesquisa. Avaliação (Campinas), Sorocaba, v. 20, n. 1, p. 163-187, Mar. 2015. Disponível em: <http://www.scielo.br/scielo.php?script=sci arttext\&pid=S141440772015000100163\&lng=en\&nrm=iso $>$. Acesso em: 21 ago. 2020.

CLÉMENT, P. Conceptions, représentations sociales et modèle KVP. Skholê : cahiers de la recherche et du développement, Marseille : IUFM de l'académie d'Aix-Marseille, 2010, 16, pp.55 - 70. Disponível em: <https://hal.archives-ouvertes.fr/hal01024972/document>. Acesso em: 21 ago. 2020.

COSTA, W. N. G. Dissertações e Teses Multipaper: uma breve revisão bibliográfica. In: VIII Seminário Sul-Mato-Grossense de Pesquisa em Educação Matemática, 2014, Campo Grande, MS. Anais ... Campo Grande, MS: UFMS, 2014. Disponível em: $<$ https://periodicos.ufms.br/index.php/sesemat/article/view/3086>. Acesso em: 21 ago. 2020.

DEBOER, G. E. Scientific literacy: another look at its historical and contemporary meanings and its relationship to science education reform. Journal of Research in Science Teacher, v. 37, n. 6, p. 582-601, ago. 2000.

ESTRELA, M. T. As Ciências da Educação Hoje. In: FERREIRA, N. S. C.; BITTANCOURT, A. B. (Org.), Formação Humana e Gestão da Educação. A arte de Pensar Ameaçada. São Paulo: Cortez, p. 17-50, 2008.

FAZENDA, I. C. A. Interdisciplinaridade: um projeto em parceria, São Paulo, SP: Edições Loyola, 2002.

FERREIRA, N. S. A. Pesquisa em leitura: um estudo dos resumos de dissertações de mestrado e teses de doutorado defendidas no Brasil, de 1980 a 1995. 1999. $110 \mathrm{f}$. Tese (Doutorado) - Faculdade de Educação da Universidade Estadual de Campinas, 
Campinas, SP. Disponível em: <http://repositorio.unicamp.br/jspui/handle/REPOSIP /252655>. Acesso em: 21 ago. 2020.

As pesquisas denominadas "Estado da Arte". Educação \& Sociedade, v. 23, n. 79, p.257-272, Agosto de 2002. Disponível em: <http://www.scielo.br/scielo. php?script=sci arttext\&pid=S0101-73302002000300016\&lng=en\&nrm=iso $>$. Acesso em: 21 ago. 2020.

FIORENTINI, D. Rumos da pesquisa brasileira em educação matemática. 1994. 425 f. Tese (Doutorado) - Faculdade de Educação, Universidade Estadual de Campinas, Campinas, 1994.

FORATO, T. C. M.; PIETROCOLA, M.; MARTINS, R. A. Historiografia e natureza da Ciência na sala de aula. Caderno Brasileiro de Ensino de Física, Florianópolis, v. 28, n. 1, p. 27-59, jan. 2011. Disponível em: < $\underline{\text { https://periodicos.ufsc.br }}$ /index.php/fisica/article/view/2175-7941.2011v28n1p27>. Acesso em: 21 ago. 2020.

FRACALANZA, H. O que sabemos sobre os livros didáticos para o ensino de ciências no Brasil. 1992. 302 f. Tese (Doutorado) - Faculdade de Educação, Universidade Estadual de Campinas, Campinas, 1993. Disponível em: http://repositorio.unicamp.br/handle/REPOSIP/253708>. Acesso em: 21 ago. 2020.

FRACALANZA, H.; MEGID NETO, J. (Org.). O livro didático de Ciências no Brasil. Campinas: Komedi, 2006. 224 p.

FREITAG, B., MOTTA, V. R., COSTA, W. F. O Estado da Arte do livro didático no Brasil. Brasília: INEP/REDUC, 1987.129 p.

GADOTTI, M. Pedagogia da práxis. 2. Ed. São Paulo: Cortez, 1998. 333 p. Disponível em: http://www.acervo.paulofreire.org:8080/jspui/handle/7891/2793. Acesso em: 21 ago. 2020.

GIBBONS, M. et al. La nueva producción del conocimiento: La dinámica de la ciencia y la investigación en las sociedades contemporáneas. Barcelona: PomaresCorredor, 1997. 
GIL PÉREZ, D. et al . Para uma imagem não deformada do trabalho científico. Ciência \& Educação (Bauru), Bauru , v. 7, n. 2, p. 125-153, 2001. Disponível em: $<$ http://www.scielo.br/scielo.php?script=sci arttext\&pid=S1516-73162001000200001 \&lng=en\&nrm=iso>. Acesso em: 21 ago. 2020.

GIMENO SACRISTÁN, J. et al. Educar por competência: o que há de novo? Porto Alegre: Artmed, 2011. 264 p.

HADDAD, S. (Coord.). Evolução de jovens e adultos no Brasil (1996-1998). Brasília: MEC/INEP/COMPED, 2002. 142 p. (Série Estado do Conhecimento, 8).

HURD, P. D. Scientific literacy: new minds for a changing world. Science Education, v. 82, n. 3, p. 407-416, jun. 1998.

IRZIK, G.; NOLA, R. A. Family resemblance approach to the nature of science for science education. Science Education, v. 20, n. 7-8, p. 591-607, 2011.

KATO, D. S.; KAWASAKI, C. S. As concepções de contextualização do ensino em documentos curriculares oficiais e de professores de ciências. Ciência \& Educação (Bauru), Bauru , v. 17, n. 1, p. 35-50, 2011. Disponível em: $<$ http://www.scielo.br/scielo.php?script=sci arttext\&pid=S1516-73162011000100003 \&lng=en\&nrm=iso>. Acesso em: 21 ago. 2020.

LAKATOS E. V.; MARCONI, M. A. Fundamentos de metodologia científica. 5ª ed. São Paulo: Atlas, 2003.

LEDERMAN, N. G. Students' and teachers' conceptions of the nature of science: a review of the research. Journal of Research in Science Teaching, New York, v. 29, n. 4, p. 331-359, 1992.

LEIS, H. R. Sobre o conceito de interdisciplinaridade. Cadernos de Pesquisa Interdisciplinar em Ciências Humanas, Florianópolis, v. 6, n. 73, p. 2-23, jan. 2005. ISSN 1984-8951. Disponível em: <https://periodicos.ufsc.br/index.php/cadernosde pesquisa/article/view/2176>. Acesso em: 21 ago. 2020. 
LEMGRUBER, M. S. A educação em ciências físicas e biológicas a partir das teses e dissertações (1981 a 1995): uma história de sua história. 1999. Tese (Doutorado) - Universidade Federal do Rio de Janeiro, Rio de Janeiro, 1999.

LIAKOPOULOS, M. Análise argumentativa. In: BAUER, M. W.; GASKELL, G. Pesquisa qualitativa com texto, imagem e som: um manual prático. 2. ed. Petrópolis, RJ: Vozes, 2003.

LOCATELLI, A.; ZOCH, A. N.; AMARAL, L. C. Z. Enfoque CTS no Ensino de Química: uma pesquisa do "Estado da Arte". Ensino de Ciências e Tecnologia em Revista, v. 5, n. 1, p. 34-47, 2015. Disponível em: <http://srvapp2s.urisan.tche.br/seer/ index.php/encitec/article/view/1466>. Acesso em: 21 ago. 2020.

LOPES A. R. C. Conhecimento escolar: ciência e cotidiano. Rio de Janeiro : EdUERJ, 1999. 236 p.

LORENZETTI, L.; DELIZOICOV, D. Alfabetização Científica no Contexto das Séries Iniciais. Ensaio Pesquisa em Educação em Ciências (Belo Horizonte), Belo Horizonte , v. 3, n. 1, p. 45-61, jan./jun. 2001. Disponível em: $<$ http://www.scielo.br/scielo.php?script=sci arttext\&pid=S1983-21172001000100045 \&lng=pt\&nrm=iso >. Acesso em: 21 ago. 2020.

MACHADO, N. J. Interdisciplinaridade e contextuação. In: Ministério da Educação, Instituto Nacional de Estudos e Pesquisas Educacionais Anísio Teixeira. Exame Nacional do Ensino Médio (ENEM): fundamentação teórico-metodológica. Brasília: MEC; INEP, 2005. p. 41-53.

Educação: projetos e valores. 5. ed. São Paulo: Escrituras, 2004.

MARANDINO, M. Transposição ou recontextualização? Sobre a produção de saberes na educação em museus de ciências. Revista Brasileira de Educação, Rio de Janeiro ,n. 26, p. 95-108, ago. 2004. Disponível em: $<$ http://www.scielo.br/scielo.php?script=sci arttext\&pid=S1416-24782004000200008 \&lng=en\&nrm=iso $>$. Acesso em: 21 ago. 2020. 
MARTINAND, J. L. Connaître et transformer lamatière: des objectifs pour l'initiation aux sciences et techniques. Berne: Peter Lang, 1986.

MARTINAND, J. L. Pratiques de référence et problématique de la référence curriculaire. In: TERISSE, A. (Ed.) Didactique des disciplines, les références au savoir. Bruxelles, De Boeck Université, 2001, p. 18-24.

MATHEUS, I. F.; MACIEL, M. D. Alfabetização científica no contexto de pesquisas acadêmicas em ensino de ciências. Revista Científica Multidisciplinar Núcleo do Conhecimento. Ano 04, v. 2, p. 05-22, mar. 2019. Disponível em: $<$ https://www.nucleodoconhecimento.com.br/educacao/alfabetizacao-cientifica>. Acesso em: 21 ago. 2020.

McCOMAS, W. F.; ALMAZROA, H.; CLOUGH, M. P. The nature of Science in Science education: An introduction. Science \& Education, v. 7, n. 6, p. 511-532, 1998. Disponível em: <https://link.springer.com/content/pdf/10.1023/A:1008642510402.pdf> . Acesso em: 21 ago. 2020.

MEGID NETO, J. Pesquisa em ensino de física do $2^{\circ}$ grau no Brasil: concepção e tratamento de problemas em teses e dissertações. 1990. 296 f. Dissertação (Mestrado) - Faculdade de Educação, Universidade Estadual de Campinas, Campinas, 1990. 296p. Disponível em: <http://repositorio.unicamp.br/handle /REPOSIP/251716>, Acesso em: 21 ago. 2020.

Tendências da pesquisa acadêmica sobre o ensino de ciências no nível fundamental. 1999. 365 f. Tese (Doutorado) - Faculdade de Educação, Universidade Estadual de Campinas, Campinas, 1999. Disponível em: <http://repositorio.unicamp.br/handle/REPOSIP/252565>. Acesso em: 21 ago. 2020.

MOREIRA, M. A.; OSTERMANN, F. Sobre o ensino do método científico. Caderno Brasileiro de Ensino de Física, Florianópolis, SC, v. 10, n. 2: p. 108-117, jan. 1993. Disponível em: <https://periodicos.ufsc.br/index.php/fisica/article/view/7275/14939>. Acesso em: 21 ago. 2020. 
MORIN, E. Introdução ao pensamento complexo. Trad. Eliane Lisboa. 5. ed. Porto Alegre: Sulina, 2015. 120 p.

MOROSINI, M. C.; FERNANDES, C. M. B. Estado do Conhecimento: conceitos, finalidades e interlocuções. Educação por Escrito, Porto Alegre, v. 5, n. 2, p. 154164, out. 2014. Disponível em: <https://revistaseletronicas.pucrs.br/ojs/index.php/ porescrito/article/view/18875/12399>. Acesso em: 21 ago. 2020.

MOROSINI, M. C. Estado de conhecimento e questões do campo científico. Educação, Santa Maria. v. 40, n. 1, p. 101-116, jan./abr. 2015. Disponível em: $<$ https://periodicos.ufsm.br/reveducacao/article/view/15822/pdf >. Acesso em: 21 ago. 2020.

MOURA, B. A. O que é natureza da Ciência e qual sua relação com a história e filosofia da ciência? Revista Brasileira de História da Ciência, Rio de Janeiro, v. 7, n. 1, p. 32-46, 2014. Disponível em: <https://www.sbhc.org.br/arquivo/download? ID $A R Q U I V O=1932>$. Acesso em: 21 ago. 2020.

NASSI-CALÒ, L. Teses e dissertações: prós e contras dos formatos tradicional e alternativo [online]. SciELO em Perspectiva, 2013. Disponível em: https://blog.scielo.org/blog/2013/08/24/teses-e-dissertacoes-pros-e-contras-dos-form atos-tradicional-e-alternativo. Acesso em: 21 ago. 2020.

PINHEIRO, N. A. M.; SILVEIRA, R. M. C. F.; BAZZO, W. A. O contexto científicotecnológico e social acerca de uma abordagem crítico-reflexiva: perspectiva e enfoque. Revista Iberoamericana de Educación, n. 49, v. 01, p. 1-14. Núm. Esp. 2009. Disponível em: <https://rieoei.org/historico/deloslectores/2846Maciel.pdf>. Acesso em: 21 ago. 2020.

PONTUSCHKA, N. (Org.). Ousadia do diálogo: Interdisciplinaridade na escola pública. São Paulo: Loyola, 1993.

PUMFREY, S. History of Science in the National Science Curriculum: A critical review of resources and their aims. British Journal for the History of Science, v. 24, n. 1, p. 61-78, 1991. 
REZENDE, F.; OSTERMANN, F.; FERRAZ, G. Ensino-aprendizagem de física no nível médio: o estado da arte da produção acadêmica no século XXI. Revista Brasileira de Ensino de Física, v. 31, n. 1, p. 1402.1-1402.8, abril 2009. Disponível em: $\quad<$ http://www.scielo.br/scielo.php?script=sci arttext\&pid=S1806-1117200900010 0008\&lng=en\&nrm=iso $>$. Acesso em: 21 ago. 2020.

RODRIGUES, A. F. Alfabetização científica em sequências didáticas disponíveis no site da Revista Nova Escola. 2013. f. 69. Monografia (Graduação) - Faculdade de Filosofia, Ciências e Letras de Ribeirão Preto, Universidade de São Paulo, Ribeirão Preto, 2013.

ROMANOWSKI, J. P.; ENS, R. T. As pesquisas denominadas do tipo "Estado da Arte" em educação. Diálogo Educacional., v. 6, n. 19, p. 37-50, jul. 2006. Disponível em: <https://periodicos.pucpr.br/index.php/dialogoeducacional/article/view/24176>. Acesso em: 21 ago. 2020.

SANTANA, R. S.; FRANZOLIN, F. As pesquisas em ensino de ciências por investigação nos anos iniciais: o estado da arte. Ensino em Re-Vista, v. 23, n. 2, p. 504-521, nov. 2016. Disponível em: http://www.seer.ufu.br/index.php/emrevista/ article/view/36498/19252. Acesso em: 21 ago. 2020.

SANTANA, R. S.; SOFIATO, C. G. O estado da arte das pesquisas sobre o ensino de Ciências para estudantes surdos. Práxis Educativa, v. 16, n. 2, p. 596-616, maio/ago. 2018. Disponível em: <http://www.revistas2.uepg.br/index.php/praxiseducativa> Acesso em: 21 ago. 2020.

SANTOS, W. L. P.; MORTIMER, E. F. Tomada de decisão para ação social responsável no ensino de ciências. Ciências \& Educação (Bauru), Bauru , v. 7, n. 1, p. 95-111, 2001 . Disponível em: <http://www.scielo.br/scielo.php?script=sci arttext\&pid=S1516-73162001000100007\&Ing=en\&nrm=iso >. Acesso em: 21 ago. 2020.

Uma análise de pressupostos teóricos da abordagem C-T-S (Ciência Tecnologia - Sociedade) no contexto da educação brasileira. Ensaio Pesquisa em Educação em Ciências (Belo Horizonte), Belo Horizonte , v. 2, n. 2, p. 110-162, 
dez. 2000. Disponível em: <http://www.scielo.br/scielo.php?script=sci arttext\&pid= S1983-21172000000200110\&lng=pt\&nrm=iso >. Acesso em: 21 ago. 2020.

SANTOS, W. L. P. Contextualização no ensino de ciências por meio de temas CTS em uma perspectiva crítica. Ciência \& Ensino, v. 1, núm. esp., nov. 2007. Disponível em: <http://143.0.234.106:3537/ojs/index.php/cienciaeensino/article/view/149/120>. Acesso em: 21 ago. 2020.

SASSERON, L. H. Alfabetização científica, ensino por investigação e argumentação: relações entre Ciências da Natureza e escola. Ensaio Pesquisa em Educação em Ciências (Belo Horizonte), Belo Horizonte , v. 17, n. spe, p. 49-67, nov. 2015. Disponível em: <http://www.scielo.br/scielo.php?script=sci arttext\&pid=S198321172015000400049\&lng=pt\&nrm=iso >. Acesso em: 21 ago. 2020.

SASSERON, L. H; CARVALHO, A. M. P. Alfabetização científica: uma revisão bibliográfica. Investigações em Ensino de Ciências, v.16, n. 1, p. 59-77, 2011. Disponível em: <https://www.if.ufrgs.br/cref/ojs/index.php/ienci/article/view/246/172>. Acesso em: 21 ago. 2020.

Almejando alfabetização científica no ensino fundamental: a proposição e a procura de indicadores do processo. Investigações em Ensino de Ciencias, v. 16, n. 3, p. 333-352, 2008. Disponível em: <https://www.if.ufrgs.br/cref/ojs/index. php/ienci/article/view/445/263>. Acesso em: 21 ago. 2020.

SCHNEIDER-FELICIO, B. V. Formação de Conceitos da termoquímica em meio a relações CTSA e questões sociocientíficas: contribuições da teoria da atividade histórico-cultural. São Paulo, 2018. Tese (Doutorado). Universidade de São Paulo. Faculdade de Educação. Instituto de Física, Instituto de Química, Instituto de Biociências. 2018. Disponível em: <https://teses.usp.br/teses/disponiveis/81/81162/ tde-25072018-165159/publico/Beatriz Skalee Schneider Felicio.pdf>. Acesso em: 21 ago. 2020.

SHAMOS, M. H. The myth of scientific literacy. New Brunswick: Rutgers University Press, 1995. $261 \mathrm{p}$. 
SLONGO, I. I. P. A produção acadêmica em ensino de biologia: um estudo a partir de teses e dissertações. Florianópolis. 2004, 349 f. Tese (Doutorado) - Centro de Ciências da Educação, Universidade Federal de Santa Catarina, Santa Catarina, 2004. Disponível em: <https://repositorio.ufsc.br/xmlui/handle/123456789/88012>. Acesso em: 21 ago. 2020.

SOARES, M. B.; MACIEL, F. Alfabetização. Brasília: MEC/INEP/COMPED, 2000. (Série Estado do Conhecimento, 1). Disponível em: <http://portal.inep.gov.br/documents/186968/484330/Alfabetiza\%C3\%A7\%C3\%A3o/f 9ddff4f-1708-41fa-82e5-4f2aa7c6c581?version=1.3>. Acesso em: 21 ago. 2020.

SHEN, B. S. P. Science Literacy: Public understanding of science is becoming vitally needed in developing and industrialized countries alike. American Scientist, v. 63, n. 3, p. 265-268, may/jun. 1975.

TEIXEIRA, P. M. M.; MEGID NETO, J. Pesquisa em Ensino de Biologia no Brasil (1972-2004): um estudo com base em dissertações e teses. In: VI Encontro Nacional de Pesquisa em Educação em Ciências, 2007, Florianópolis. Anais ... Florianópolis: ABRAPEC, 2007. Disponível em: <http://abrapecnet.org.br/atas enpec/vienpec/orais0.html>. Acesso em: 21 ago. 2020.

THE past, present and future of the PhD thesis: Writing a PhD thesis is a personal and professional milestone for many researchers. But the process needs to change with the times. [Editorial]. Nature, v. 535, n. 7610, p. 7, jul. 2016. Disponível em: $<$ https://www.nature.com/news/the-past-present-and-future-of-the-phd-thesis-1.2020 7>. Acesso em: 21 Ago. 2020.

VIECHENESKI, J. P.; LORENZETTI, L.; CARLETTO, M. R. A alfabetização científica nos anos iniciais: uma análise dos trabalhos apresentados nos ENPECs. In: X Encontro Nacional de Pesquisa em Educação em Ciências, 2015. Anais... Águas de Lindóia, SP: ABRAPEC, 2015. Disponível em: <http://www.abrapecnet.org.br lenpec/x-enpec/anais2015/busca.htm?query=VIECHENESKI>. Acesso em: 21 ago. 2020. 
WARTHA, E. J. e ALÁRIO, A. F. A contextualização no ensino de química através do livro didático. Química Nova na Escola, São Paulo, n. 22, nov. 2005. p. 42-47. Disponível em: <http://qnesc.sbq.org.br/online/qnesc22/a09.pdf>. Acesso em: 21 ago. 2001. 


\section{Anexos}

Anexo A - Metadados do Catálogo de Teses e Dissertações da Capes, Dados das Teses e Dissertações da Pós-Graduação 2013 a 2016. 


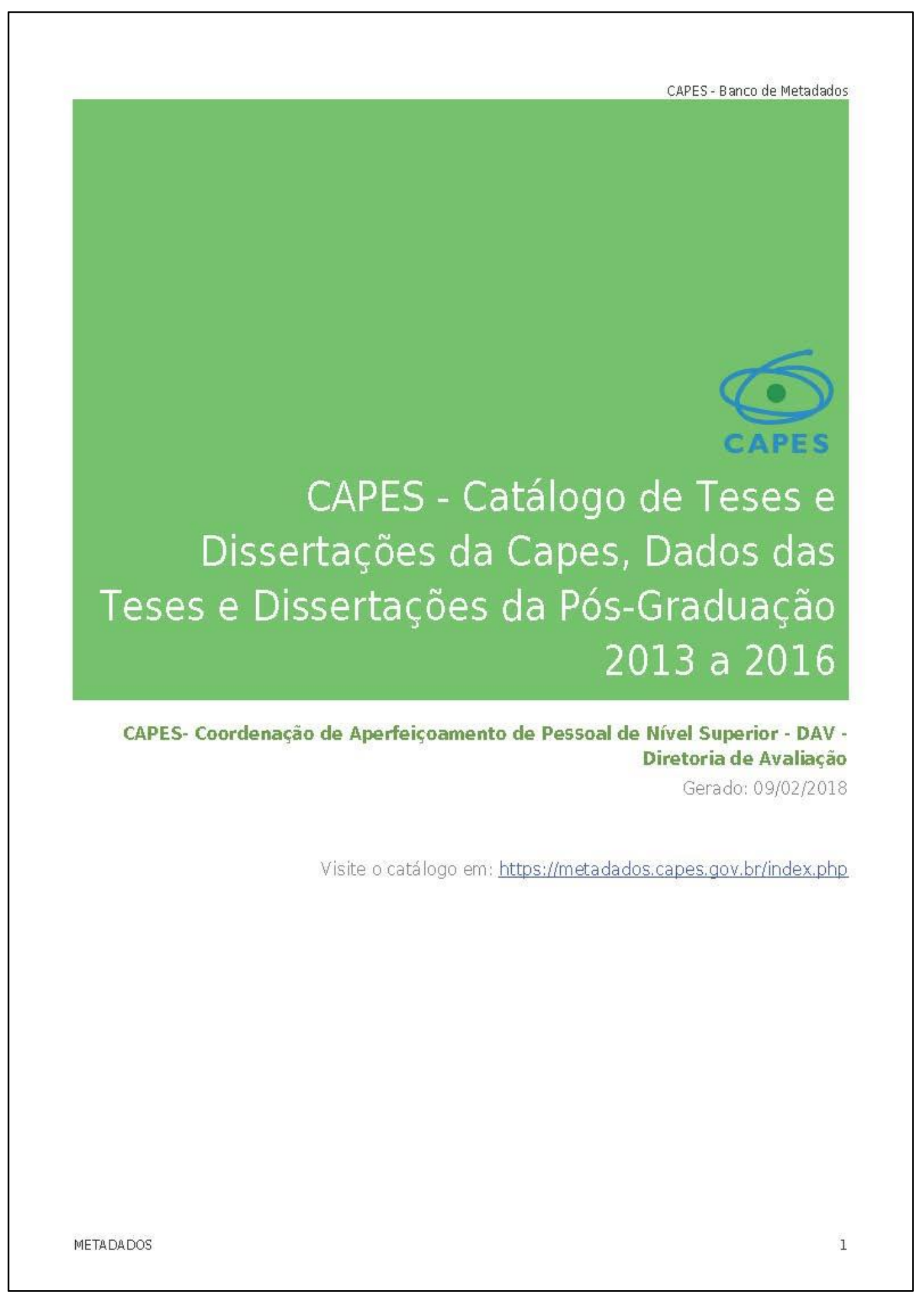




\section{Informação geral}

\section{Identificação}

NÚMERO DE ID

BR-CAPES-BTD-2013A2016-2017-12-01

\section{Versão}

PERIODICIDADE DE ATUALIZAÇÃO

Versão 1.0 - Dados brutos.

DATA DE PRODUÇÃO

2017-12-18

\section{Informação geral}

ARQUIVO DE CARGA

O BTD da Capes é uma plataforma que tem como objetivo facilitar o acesso a informações sobre teses e dissertações defendidas junto a programas de pós-graduação do país, além de disponibilizar informações estatísticas acerca deste tipo de produção intelectual, e faz parte do Portal de Periódicos da Instituição.

Os dados referenciados neste metadados contém informações sobre as Teses e Dissertações da Pós-Graduação do ano de 1987.

CARGA

Registos administrativos [adm]

UNIDADE DE ANÁLISE

Produto

\section{Âmbito}

NOTAS

Principais variáveis: Nome da Tese ou Dissertação, Área de avaliação, Área de Conhecimento, Nome do autor, data de defesa.

Variáveis derivadas: Região da IES, Número de páginas.

TÓPICOS

\begin{tabular}{|l|l|l|}
\hline Tema & Vocabulário & URL \\
\hline Educação & CIE-IBGE & \\
\hline
\end{tabular}

PALAVRAS CHAVES

Teses, Dissertações, Pós-Graduação, Educação

\section{Cobertura}

COBERTURA GEOGRáFICA

Nacional 
UNIDADE GEOGRÁFICA

Município

UNIVERSO

Discentes de Pós-Graduação no Brasil.

\section{Produtores e Patrocinadores}

INVESTIGADOR(ES) PRIMÁRIO(S)

\section{Nome}

Dependência

CAPES- Coordenação de Aperfeiçoamento de Pessoal de Nível Superior

DAV - Diretoria de Avaliação

OUTROS PRODUTORES

\begin{tabular}{|l|l|l|}
\hline Nome & Dependência & Filiação \\
\hline Instituições de Ensino & Geradora dos dados & Informante \\
\hline
\end{tabular}

FINANCIADORES

\begin{tabular}{|l|l|l|}
\hline Nome & Abreviação & Filiação \\
\hline Coordenação de Aperfeiçoamento de Pessoal de Nível Superior & CAPES & \\
\hline
\end{tabular}

\section{Produção de metadado}

METADADO PRODUZIDO POR

\begin{tabular}{|l|l|l|l|}
\hline Nome & Abreviação & Dependência & Filiação \\
\hline $\begin{array}{l}\text { CAPES- Coordenação de Aperfeiçoamento de Pessoal de } \\
\text { Nível Superior }\end{array}$ & CAPES & DTI & Banco de Dados - Estatística \\
\hline
\end{tabular}

DATA DE PRODUÇÃO DO METADADO

2017-12-18

VERSÄO DO DOCUMENTO DDI

Versão 1.0

IDENTIFICADOR DO DOCUMENTO DDI

DDI-BR-CAPES-BTD-2013A2016-2017-12-01 


\section{Lista de variáveis}

\section{ADD_SNPG - ADD_TRABALHO_CONCLUSAO}

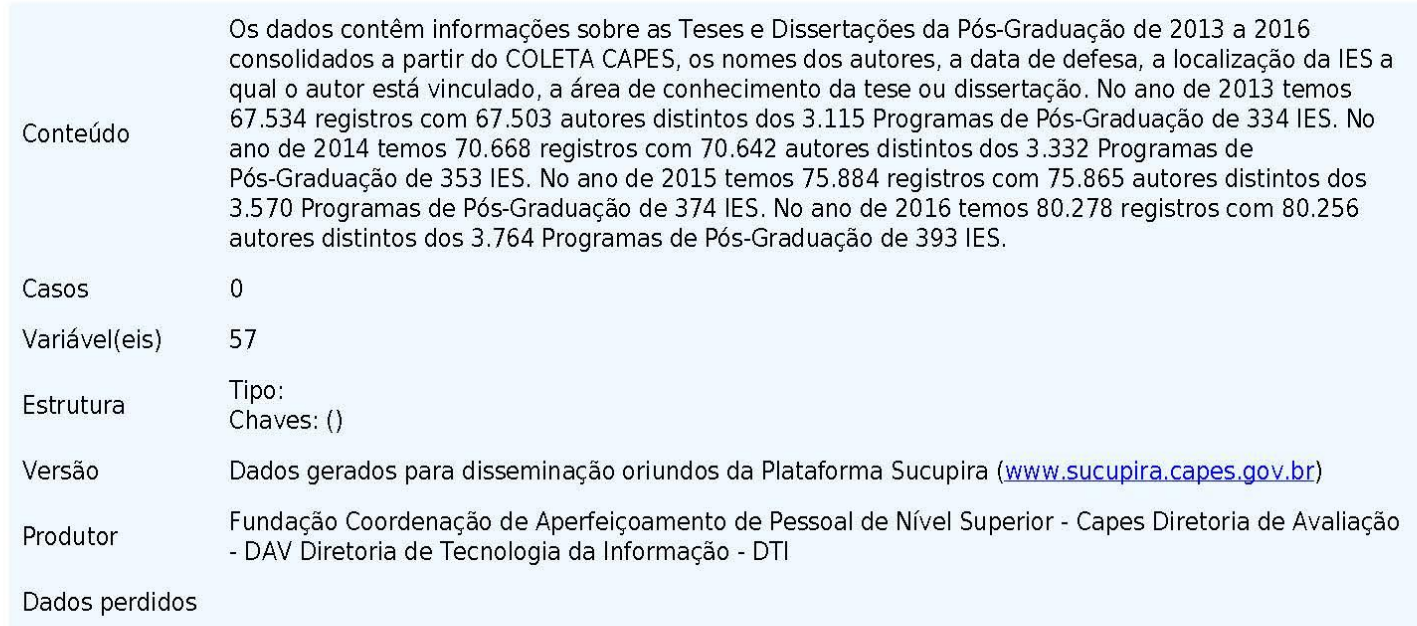

\section{Variável}

\begin{tabular}{|c|c|c|c|c|c|}
\hline ID & Código & Nome & Tipo & Formato & Pergunta \\
\hline V62 & AN_BASE & Ano Base de Coleta dos Dados & discrete & numeric & \\
\hline V65 & CD_PROGRAMA & Código de Identificação do Programa & discrete & character & \\
\hline V66 & NM_PROGRAMA & Nome do Programa & discrete & character & \\
\hline V67 & SG_ENTIDADE_ENSINO & Sigla da Entidade de Ensino & discrete & character & \\
\hline V68 & NM_ENTIDADE_ENSINO & Nome da Entidade de Ensino & discrete & character & \\
\hline V69 & ID_ADD_PRODUCAO_INTELECTUAL & $\begin{array}{l}\text { Identificador do Produto no Ano Base e no } \\
\text { Programa na Base de Dados da CAPES }\end{array}$ & discrete & numeric & \\
\hline$\vee 70$ & ID_PRODUCAO_INTELECTUAL & $\begin{array}{l}\text { Identificador do Produto na Base de Dados } \\
\text { da CAPES }\end{array}$ & discrete & numeric & \\
\hline V71 & NM_PRODUCAO & Nome da Produção & discrete & character & \\
\hline V72 & ID_SUBTIPO_PRODUCAO & Identificador do Subtipo da Produção & discrete & numeric & \\
\hline V73 & NM_SUBTIPO_PRODUCAO & Nome do Subtipo da Produção & discrete & character & \\
\hline V74 & ID_AREA_CONCENTRACAO & Identificador da área de concentração & discrete & numeric & \\
\hline V75 & NM_AREA_CONCENTRACAO & Nome da área de concentração & discrete & character & \\
\hline V76 & ID_LINHA_PESQUISA & Identificador da Linha de Pesquisa & discrete & numeric & \\
\hline V77 & NM_LINHA_PESQUISA & Nome da Linha de Pesquisa & discrete & numeric & \\
\hline V78 & ID_PROJETO & Identificador do Projeto & discrete & numeric & \\
\hline V79 & NM_PROJETO & Nome do Projeto & discrete & numeric & \\
\hline V80 & DH_INICIO_AREA_CONC & $\begin{array}{l}\text { Data e Hora do Início da Área de } \\
\text { Concentração }\end{array}$ & discrete & numeric & \\
\hline V81 & DH_FIM_AREA_CONC & $\begin{array}{l}\text { Data e Hora do Fim da Área de } \\
\text { Concentração }\end{array}$ & discrete & numeric & \\
\hline
\end{tabular}


CAPES - Catálogo de Teses e Dissertações da Capes, Dados das Teses e Dissertações da Pós-Graduação 2013 a 2016 CAPES

\begin{tabular}{|c|c|c|c|c|c|}
\hline ID & Código & Nome & Tipo & Formato & Pergunta \\
\hline V82 & DH_INICIO_LINHA & Data e Hora do Início da Linha de Pesquisa & discrete & numeric & \\
\hline V83 & DH_FIM_LINHA & Data e Hora do Fim da Linha de Pesquisa & discrete & numeric & \\
\hline V84 & DT_TITULACAO & Data da Titulação & discrete & character & \\
\hline V85 & DS_PALAVRA_CHAVE & Descrição da Palavra Chave & discrete & character & \\
\hline V86 & DS_ABSTRACT & Descrição do Abstract & discrete & character & \\
\hline V87 & DS_KEYWORD & Drscrição do Keyword & discrete & character & \\
\hline V88 & IN_TRABALHO_MESMA_AREA & & discrete & numeric & \\
\hline V89 & NM_TP_VINCULO & Nome do Tipo de vinculo & discrete & character & \\
\hline V90 & IN_ORIENT_PARTICIPOU_BANCA & $\begin{array}{l}\text { Indicador se o Orientador Participou da } \\
\text { Banca }\end{array}$ & discrete & numeric & \\
\hline V91 & DS_BIBLIOTECA_DEPOSITARIA & Descrição da Biblioteca Depositária & discrete & character & \\
\hline V92 & ID_TP_EXPECTATIVA_ATUACAO & $\begin{array}{l}\text { Identificador do Tipo de Expectativa da } \\
\text { Atuação }\end{array}$ & discrete & numeric & \\
\hline V93 & NM_EXPECTATIVA_ATUACAO & Nome da Expectativa da Atuação & discrete & character & \\
\hline V123 & ID_PESSOA_DISCENTE & $\begin{array}{l}\text { Código de identificação da pessoa na base } \\
\text { de dados da CAPES }\end{array}$ & discrete & numeric & \\
\hline V95 & NM_DISCENTE & Nome do Discente & discrete & character & \\
\hline V98 & DT_MATRICULA & Data da Matrícula do Discente & discrete & character & \\
\hline V99 & ID_GRAU_ACADEMICO & $\begin{array}{l}\text { Identificador do Grau Acadêmico ao qual o } \\
\text { discente está vinculado }\end{array}$ & discrete & numeric & \\
\hline V100 & NM_GRAU_ACADEMICO & $\begin{array}{l}\text { Nome do Grau Acadêmico ao qual o } \\
\text { discente está vinculado }\end{array}$ & discrete & character & \\
\hline V102 & NM_ORIENTADOR & Nome do Orientador & discrete & character & \\
\hline V103 & DS_CATEGORIA_ORIENTADOR & Descrição da Categoria do Orientador & discrete & character & \\
\hline V104 & NM_CATEGORIA_DOCENTE & Nome da Categoria do Docente & discrete & character & \\
\hline V105 & NM_REGIAO & Nome da Região da IES & discrete & character & \\
\hline V106 & SG_UF_IES & Sigla da Unidade da Federação da IES & discrete & character & \\
\hline V107 & NM_UF_IES & Nome da Unidade da Federação da IES & discrete & character & \\
\hline V108 & CD_GRANDE_AREA_CONHECIMENTO & $\begin{array}{l}\text { Código da Grande Área de Conhecimento a } \\
\text { que a Produção esta vinculada }\end{array}$ & discrete & numeric & \\
\hline V109 & NM_GRANDE_AREA_CONHECIMENTO & $\begin{array}{l}\text { Nome da Grande Área de Conhecimento a } \\
\text { que a Produção esta vinculada }\end{array}$ & discrete & character & \\
\hline V110 & CD_AREA_CONHECIMENTO & $\begin{array}{l}\text { Código da Área de Conhecimento a que o } \\
\text { Programa de Pós-Graduação está } \\
\text { vinculada }\end{array}$ & discrete & numeric & \\
\hline V111 & NM_AREA_CONHECIMENTO & $\begin{array}{l}\text { Nome da Área de Conhecimento a que o } \\
\text { Programa de Pós-Graduação está } \\
\text { vinculada }\end{array}$ & discrete & character & \\
\hline V112 & CD_SUBAREA_CONHECIMENTO & $\begin{array}{l}\text { Código da Subárea de Conhecimento a que } \\
\text { o Programa de Pós-Graduação está } \\
\text { vinculada }\end{array}$ & discrete & character & \\
\hline V113 & NM_SUBAREA_CONHECIMENTO & $\begin{array}{l}\text { Nome da Subárea de Conhecimento a que } \\
\text { o Programa de Pós-Graduação está } \\
\text { vinculada }\end{array}$ & discrete & character & \\
\hline
\end{tabular}


CAPES - Catálogo de Teses e Dissertações da Capes, Dados das Teses e Dissertações da Pós-Graduação 2013 a 2016 CAPES

\begin{tabular}{|c|c|c|c|c|c|}
\hline ID & Código & Nome & Tipo & Formato & Pergunta \\
\hline V114 & CD_ESPECIALIDADE & Código da Especialidade & discrete & character & \\
\hline V115 & NM_ESPECIALIDADE & Nome da Especialidade & discrete & character & \\
\hline V116 & NM_AREA_AVALIACAO & Nome da Área de Avaliação & discrete & character & \\
\hline V117 & DS_EMAIL_DISCENTE & Descrição do E-mail do Discente & discrete & character & \\
\hline V118 & NR_VOLUME & Número do Volume da Produção & discrete & numeric & \\
\hline V119 & NR_PAGINAS & Número de Páginas da Produção & discrete & numeric & \\
\hline V120 & NM_IDIOMA & Nome do Idioma da Produção & discrete & character & \\
\hline V121 & DS_RESUMO & Descrição do Resumo & discrete & character & \\
\hline V122 & DS_URL_TEXTO_COMPLETO & Descrição da URL do Texto Completo & discrete & character & \\
\hline V125 & ID_PESSOA_ORIENTADOR & $\begin{array}{l}\text { Código de identificação da pessoa } \\
\text { orientador na base de dados da CAPES }\end{array}$ & discrete & numeric & \\
\hline
\end{tabular}


Ano Base de Coleta dos Dados (AN_BASE)

Arquivo: ADD_SNPG - ADD_TRABALHO_CONCLUSAO

Informação geral

Tipo: Discreto

Formato: numeric

Definição

Ano Base de Coleta dos Dados

Código de Identificação do Programa (CD_PROGRAMA)

Arquivo: ADD_SNPG - ADD_TRABALHO_CONCLUSAO

Informação geral

Tipo: Discreto

Formato: character

Tamanho: 8

\section{Definição}

O Código do programa é gerado a partir do código da IES na Capes, já que o programa é vinculado a IES. O código do programa é único.

Nome do Programa (NM_PROGRAMA)

Arquivo: ADD_SNPG - ADD_TRABALHO_CONCLUSAO

\section{Informação geral}

Tipo: Discreto

Formato: character

Tamanho: 8

\section{Definição}

Nome do Programa ao qual a produção está vinculada.

Nome do Programa de Pós-Graduação, informado pela Instituição e aprovado pelo Ministério da Educação.

Sigla da Entidade de Ensino (SG_ENTIDADE_ENSINO)

Arquivo: ADD_SNPG - ADD_TRABALHO_CONCLUSAO

\section{Informação geral}

Tipo: Discreto

Formato: character

Tamanho: 8

\section{Definição}

Sigla da IES (Instituição de Ensino Superior) a qual a Tese ou Dissertação está vinculada.

Nome da Entidade de Ensino (NM_ENTIDADE_ENSINO)

Arquivo: ADD_SNPG - ADD_TRABĀLHO_CONCLUSAO

\section{Informação geral}

Tipo: Discreto

Formato: character

Tamanho: 8

\section{Definição}

Nome da IES (Instituição de Ensino Superior) a qual a Tese ou Dissertação está vinculada. 
Identificador do Produto no Ano Base e no Programa na Base de Dados da CAPES (ID_ADD PRODUCAO INTELECTUAL) Arquivo: ADD_SNPG - ADD_TRABALHO_CONCLUSAO

\section{Informação geral}

Tipo: Discreto

Formato: numeric

\section{Definição}

Identificação da Tese ou Dissertação no Ano Base e no Programa na Base de Dados da CAPES

Identificador do Produto na Base de Dados da CAPES (ID_PRODUCAO_INTELECTUAL)

Arquivo: ADD_SN̄PG - ADD_TRABALHO_CONCLUSAO

\section{Informação geral}

Tipo: Discreto

Formato: numeric

\section{Definição}

Identificador da Tese ou Dissertação na Base de Dados da CAPES

Nome da Produção (NM_PRODUCAO)

Arquivo: ADD_SNPG - ADD_TRABALHO_CONCLUSAO

\section{Informação geral}

Tipo: Discreto

Formato: character

Tamanho: 255

\section{Definição}

Título da Tese ou Dissertação

Identificador do Subtipo da Produção (ID_SUBTIPO_PRODUCAO) Arquivo: ADD_SNPG - ADD_TRABALHO_C_ONCLUSĀO

\section{Informação geral}

Tipo: Discreto

Formato: numeric

\section{Definição}

Identificador do Subtipo da Produção

Notas

Os subtipos da Produção são de acordo com o Grau Acadêmico, sendo:

Tese - Doutorado e

Dissertação - Mestrado e Mestrado Profissional.

Para alguns casos de Mestrado Profissional temos outras modalidades de Trabalho de conclusão de curso.

Nome do Subtipo da Produção (NM_SUBTIPO_PRODUCAO) Arquivo: ADD_SNPG - ADD_TRABALHO_CONCLUSAO

Informação geral 
Nome do Subtipo da Produção (NM_SUBTIPO_PRODUCAO)

Arquivo: ADD_SNPG - ADD_TRABALHO_CONCLLUSAO

Tipo: Discreto

Casos válidos: 0

Formato: character

Inválido: 0

Tamanho: 8

\section{Definição}

Nome do Subtipo da Produção

\section{Notas}

Os subtipos da Produção são de acordo com o Grau Acadêmico, sendo:

Tese - Doutorado e

Dissertação - Mestrado e Mestrado Profissional.

Para alguns casos de Mestrado Profissional temos outras modalidades de Trabalho de conclusão de curso.

Identificador da área de concentração (ID_AREA CONCENTRACAO) Arquivo: ADD_SNPG - ADD_TRABALHO_CONCLUSAO

\section{Informação geral}

Tipo: Discreto

Formato: numeric

Nome da área de concentração (NM_AREA_CONCENTRACAO) Arquivo: ADD_SNPG - ADD_TRABALHO_CONNCLUSAO

Informação geral

Tipo: Discreto

Formato: character

Tamanho: 8

Identificador da Linha de Pesquisa (ID_LINHA_PESQUISA)

Arquivo: ADD_SNPG - ADD_TRABALHO_CONCLUSAO

\section{Informação geral}

Tipo: Discreto

Formato: numeric

Nome da Linha de Pesquisa (NM_LINHA_PESQUISA)

Arquivo: ADD_SNPG - ADD_TRABALHO_CONCLUSAO

Informação geral

Tipo: Discreto

Formato: numeric

Identificador do Projeto (ID_PROJETO)

Arquivo: ADD_SNPG - ADD_TRABALHO_CONCLUSAO

\section{Informação geral}

Tipo: Discreto

Formato: numeric 
Nome do Projeto (NM PROJETO)

Arquivo: ADD_SNPG - ADD_TRABALHO_CONCLUSAO

Informação geral

Tipo: Discreto

Formato: numeric

Data e Hora do Início da Área de Concentração

(DH INICIO AREA CONC)

Arquivo: ADD_SNPG - ADD_TRABALHO_CONCLUSAO

Informação geral

Tipo: Discreto

Formato: numeric

Data e Hora do Fim da Área de Concentração (DH_FIM_AREA_CONC) Arquivo: ADD_SNPG - ADD_TRABALHO_CONCLUSAO

\section{Informação geral}

Tipo: Discreto

Formato: numeric

Data e Hora do Início da Linha de Pesquisa (DH_INICIO_LINHA) Arquivo: ADD_SNPG - ADD_TRABALHO_CONCLUSAO

Informação geral

Tipo: Discreto

Formato: numeric

Data e Hora do Fim da Linha de Pesquisa (DH_FIM_LINHA)

Arquivo: ADD_SNPG - ADD_TRABALHO_CONC̄LUSĀO

Informação geral

Tipo: Discreto

Formato: numeric

Data da Titulação (DT_TITULACAO)

Arquivo: ADD_SNPG - ADD_TRABALHO_CONCLUSAO

Informação geral

Tipo: Discreto

Formato: character

Tamanho: 8

Definição

Data da Titulação do Autor da Produção 
Descrição da Palavra Chave (DS_PALAVRA_CHAVE)

Arquivo: ADD_SNPG - ADD_TRABALHO_CONCLUSAO

Informação geral

Tipo: Discreto

Formato: character

Tamanho: 255

\section{Definição}

Palavras Chave da Tese ou Dissertação

Descrição do Abstract (DS ABSTRACT)

Arquivo: ADD_SNPG - ADD_TRABALHO_CONCLUSAO

\section{Informação geral}

Tipo: Discreto

Formato: character

Tamanho: 8

Drscrição do Keyword (DS_KEYWORD)

Arquivo: ADD_SNPG - ADD_TRABALHO_CONCLUSAO

Informação geral

Tipo: Discreto

Formato: character

Tamanho: 8

(IN_TRABALHO_MESMA_AREA)

Arquivo: ADD_SNPG - ADD_TRABALHO_CONCLUSAO

Informação geral

Tipo: Discreto

Formato: numeric

Nome do Tipo de vinculo (NM TP VINCULO)

Arquivo: ADD_SNPG - ADD_TRABĀLHO_CONCLUSAO

Informação geral

Tipo: Discreto

Formato: character

Tamanho: 8

\section{Definição}

Nome do tipo de vínculo do Orientador com a IES do Programa.

Indicador se o Orientador Participou da Banca

(IN_ORIENT_PARTICIPOU_BANCA)

Arquivo: ADD_SNPG - ADD_TRABALHO_CONCLUSAO

Informação geral 
Indicador se o Orientador Participou da Banca

(IN_ORIENT_PARTICIPOU_BANCA)

Arquivo: ADD_SNPG - ADD_TRABALHO_CONCLUSAO

Tipo: Discreto

Formato: numeric

Descrição da Biblioteca Depositária (DS_BIBLIOTECA_DEPOSITARIA) Arquivo: ADD_SNPG - ADD_TRABALHO_CONCLUSAO

\section{Informação geral}

Tipo: Discreto

Formato: character

Tamanho: 8

Definição

Biblioteca Depositaria da Tese ou Dissertação

Identificador do Tipo de Expectativa da Atuação

(ID_TP_EXPECTATIVA_ATUACAO)

Arquivo: ADD_SNPG - ADD_TRABALHO_CONCLUSAO

Informação geral

Tipo: Discreto

Formato: numeric

Nome da Expectativa da Atuação (NM_EXPECTATIVA_ATUACAO)

Arquivo: ADD_SNPG - ADD_TRABALHO_CONCLUSAO

\section{Informação geral}

Tipo: Discreto

Formato: character

Tamanho: 8

Código de identificação da pessoa na base de dados da CAPES

(ID_PESSOA_DISCENTE)

Arquivo: ADD_SNPG - ADD_TRABALHO_CONCLUSAO

\section{Informação geral}

Tipo: Discreto

Formato: numeric

\section{Definição}

Identifica o discente enquanto pessoa na base de dados da Capes em relação ao seu cadastro de Pessoa Física na Receita Federal. Tal identificador é único, independente do vínculo da pessoa enquanto discente, grau acadêmico e Programa de Pós-Graduação.

Nome do Discente (NM DISCENTE)

Arquivo: ADD_SNPG - ADD_TRABALHO_CONCLUSAO 
CAPES

Nome do Discente (NM_DISCENTE)

Arquivo: ADD_SNPG - ADD_TRABALHO_CONCLUSAO

Informação geral

Tipo: Discreto

Formato: character

Tamanho: 8

\section{Definição}

Nome do discente. Em geral, corresponde ao nome da pessoa na base de dados da Receita Federal, salvo atualizações nela que não tenham refletido na base de dados da Capes.

Data da Matrícula do Discente (DT_MATRICULA) Arquivo: ADD_SNPG - ADD_TRABALEHO_CONCLUSAO

Informação geral

Tipo: Discreto

Formato: character

Tamanho: 8

\section{Definição}

Data de matrícula do discente no Programa de Pós-Graduação

Identificador do Grau Acadêmico ao qual o discente está vinculado (ID_GRAU_ACADEMICO)

Arquivo: ADD_SNPG - ADD_TRABALHO_CONCLUSAO

\section{Informação geral}

Tipo: Discreto

Formato: numeric

\section{Definição}

Grau acadêmico ao qual o discente está vinculado em 31 de dezembro do ano base.

Nome do Grau Acadêmico ao qual o discente está vinculado (NM_GRAU_ACADEMICO)

Arquivo: ADD_SNPG - ADD_TRABALHO_CONCLUSAO

\section{Informação geral}

Tipo: Discreto

Formato: character

Tamanho: 8

\section{Definição}

Grau acadêmico ao qual o discente está vinculado em 31 de dezembro do ano base.

Nome do Orientador (NM ORIENTADOR)

Arquivo: ADD_SNPG - ADD_TRABALHO_CONCLUSAO

\section{Informação geral}

Tipo: Discreto

Formato: character

Tamanho: 8 
Descrição da Categoria do Orientador

(DS_CATEGORIA_ORIENTADOR)

Arquivo: ADD_SNPG - ADD_TRABALHO_CONCLUSAO

Informação geral

Tipo: Discreto

Formato: character

Tamanho: 8

\section{Definição}

Descrição da Categoria do Orientador no programa

Nome da Categoria do Docente (NM CATEGORIA DOCENTE)

Arquivo: ADD_SNPG - ADD_TRABALHO

Informação geral

Tipo: Discreto

Formato: character

Tamanho: 8

\section{Definição}

Nome da Categoria quando o Orientador for Docente no Programa.

Notas

Quando o Orientador não for Docente então esta categoria fica como NÃO INFORMADO.

Nome da Região da IES (NM REGIAO)

Arquivo: ADD_SNPG - ADD_TRABALHO_CONCLUSAO

Informação geral

Tipo: Discreto

Formato: character

Tamanho: 8

Sigla da Unidade da Federação da IES (SG_UF_IES)

Arquivo: ADD_SNPG - ADD_TRABALHO_CŌNCLUUSAO

\section{Informação geral}

Tipo: Discreto

Formato: character

Tamanho: 8

Nome da Unidade da Federação da IES (NM_UF_IES) Arquivo: ADD_SNPG - ADD_TRABALHO_CON̄CLŪSAO

Informação geral

Tipo: Discreto

Formato: character

Tamanho: 8 
Código da Grande Área de Conhecimento a que a Produção esta vinculada (CD GRANDE_AREA CONHECIMENTO) Arquivo: ADD_SNPG - ADDD_TRĀBALHO_CONCLUSAO

\section{Informação geral}

Tipo: Discreto

Formato: numeric

\section{Definição}

Código da Grande Área de Conhecimento a que o Programa de Pós-Graduação está vinculada

Nome da Grande Área de Conhecimento a que a Produção esta vinculada (NM GRANDE AREA CONHECIMENTO) Arquivo: ADD_SNPG - ADD_TRABBALHO_CONCLUSAO

\section{Informação geral}

Tipo: Discreto

Formato: character

Tamanho: 8

Definição

Nome da Grande Área de Conhecimento a que o Programa de Pós-Graduação está vinculada

Código da Área de Conhecimento a que o Programa de Pós-Graduação está vinculada (CD AREA CONHECIMENTO) Arquivo: ADD_SNPG - ADD_TRABALHO_CONCLUSAO

\section{Informação geral}

Tipo: Discreto

Formato: numeric

\section{Definição}

Código da Área de Conhecimento a que o Programa de Pós-Graduação está vinculada

Nome da Área de Conhecimento a que o Programa de Pós-Graduação está vinculada (NM_AREA_CONHECIMENTO)

Arquivo: ADD_SNPG - ADD_TRABALHO_CONCLUSAO

\section{Informação geral}

Tipo: Discreto

Formato: character

Tamanho: 8

\section{Definição}

Nome da Área de Conhecimento a que o Programa de Pós-Graduação está vinculada

Código da Subárea de Conhecimento a que o Programa de Pós-Graduação está vinculada (CD SUBAREA CONHECIMENTO) Arquivo: ADD_SNPG - ADD_TRABĀLHO_CONCLLUSAO Informação geral 
Código da Subárea de Conhecimento a que o Programa de Pós-Graduação está vinculada (CD SUBAREA CONHECIMENTO) Arquivo: ADD_SNPG - ADD_TRABĀLHO_CONC̄LUSAO

Tipo: Discreto

Formato: character

Tamanho: 8

Definição

Código da Subárea de Conhecimento a que o Programa de Pós-Graduação está vinculada

Nome da Subárea de Conhecimento a que o Programa de Pós-Graduação está vinculada (NM_SUBAREA_CONHECIMENTO) Arquivo: ADD_SNPG - ADD_TRABALHO_CONCLUSAO

\section{Informação geral}

Tipo: Discreto

Formato: character

Tamanho: 8

\section{Definição}

Nome da Subárea de Conhecimento a que o Programa de Pós-Graduação está vinculada

Código da Especialidade (CD_ESPECIALIDADE) Arquivo: ADD_SNPG - ADD_TRABALHO_CONCLUSAO Informação geral

Tipo: Discreto

Formato: character

Tamanho: 8

Definição

Código da Especialidade de Conhecimento a que o Programa de Pós-Graduação está vinculada

Nome da Especialidade (NM_ESPECIALIDADE) Arquivo: ADD_SNPG - ADD_TRABALHO_CONCLUSAO

Informação geral

Tipo: Discreto

Formato: character

Tamanho: 8

Definição

Nome da Especialidade de Conhecimento a que o Programa de Pós-Graduação está vinculada

Nome da Área de Avaliação (NM AREA_AVALIACAO)

Arquivo: ADD_SNPG - ADD_TRABALHO_CONCLUSAO

\section{Informação geral}

Tipo: Discreto

Formato: character

Tamanho: 8

Definição

Nome da área de Avaliação a que o Programa de Pós-Graduação está vinculado quando do envio e homologação dos dados. 
Descrição do E-mail do Discente (DS_EMAIL_DISCENTE)

Arquivo: ADD_SNPG - ADD_TRABALHO_CONCLUSAO

Informação geral

Tipo: Discreto

Formato: character

Tamanho: 8

\section{Definição}

Email do autor (discente) da Tese ou Dissertação

Número do Volume da Produção (NR VOLUME)

Arquivo: ADD_SNPG - ADD_TRABALHO_CONCLUSAO

\section{Informação geral}

Tipo: Discreto

Formato: numeric

Definição

É o número de volumes impressos, encadernados e depositados na biblioteca depositária da Tese ou Dissertação.

Número de Páginas da Produção (NR_PAGINAS)

Arquivo: ADD_SNPG - ADD_TRABALHO_CONCLUSAO

Informação geral

Tipo: Discreto

Formato: numeric

Definição

Número de Páginas da Produção

Nome do Idioma da Produção (NM_IDIOMA)

Arquivo: ADD_SNPG - ADD_TRABALHO_CONCLUSAO

Informação geral

Tipo: Discreto

Formato: character

Tamanho: 8

Definição

Idioma da Produção

Descrição do Resumo (DS_RESUMO)

Arquivo: ADD_SNPG - ADD_TRABALHO_CONCLUSAO

Informação geral

Tipo: Discreto

Formato: character

Tamanho: 255

Definição

Resumo da Produção 
Descrição da URL do Texto Completo (DS URL TEXTO COMPLETO) Arquivo: ADD_SNPG - ADD_TRABALHO_CONCLUSAO

\section{Informação geral}

Tipo: Discreto

Formato: character

Tamanho: 255

\section{Definição}

URL do Texto Completo da Produção

Código de identificação da pessoa orientador na base de dados da CAPES (ID_PESSOA_ORIENTADOR) Arquivo: ADDDSSNG - ADD_TRABALHO_CONCLUSAO Informação geral

Tipo: Discreto

Formato: numeric

\section{Definição}

Identifica do orientador vinculado a produção enquanto pessoa na base de dados da Capes em relação ao seu cadastro de Pessoa Física na Receita Federal. Tal identificador é único, independente do vínculo da pessoa enquanto orientador, grau acadêmico e Programa de Pós-Graduação. 
Anexo B - Relação dos 276 resumos selecionados do conjunto de teses e dissertações defendidas no Brasil, no período de 2013 a 2017, e que mostraram, nos índices de indexação (título, corpo do resumo ou palavraschave), algum tipo de apropriação da temática da alfabetização científica pela pesquisa desenvolvida.

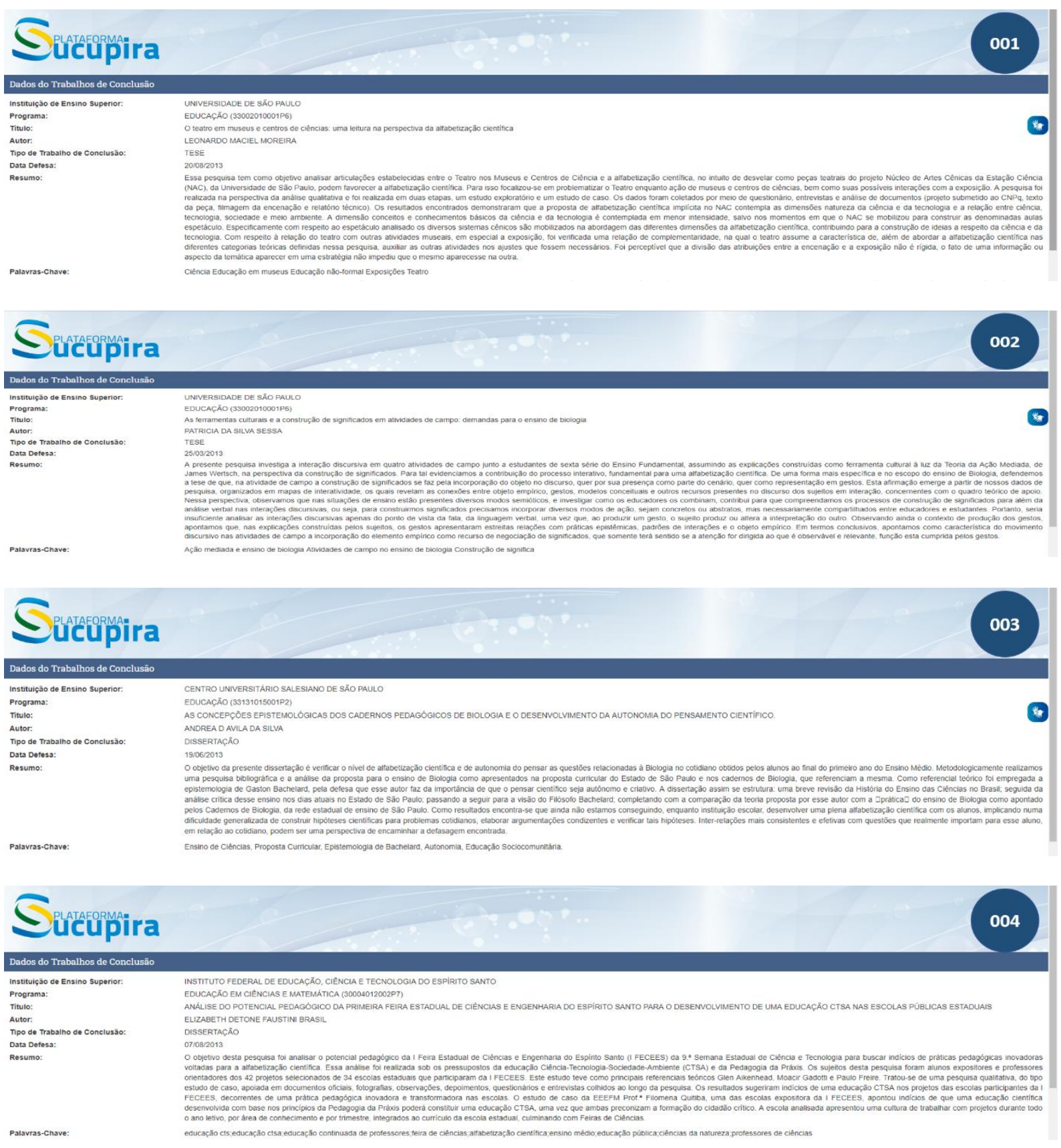



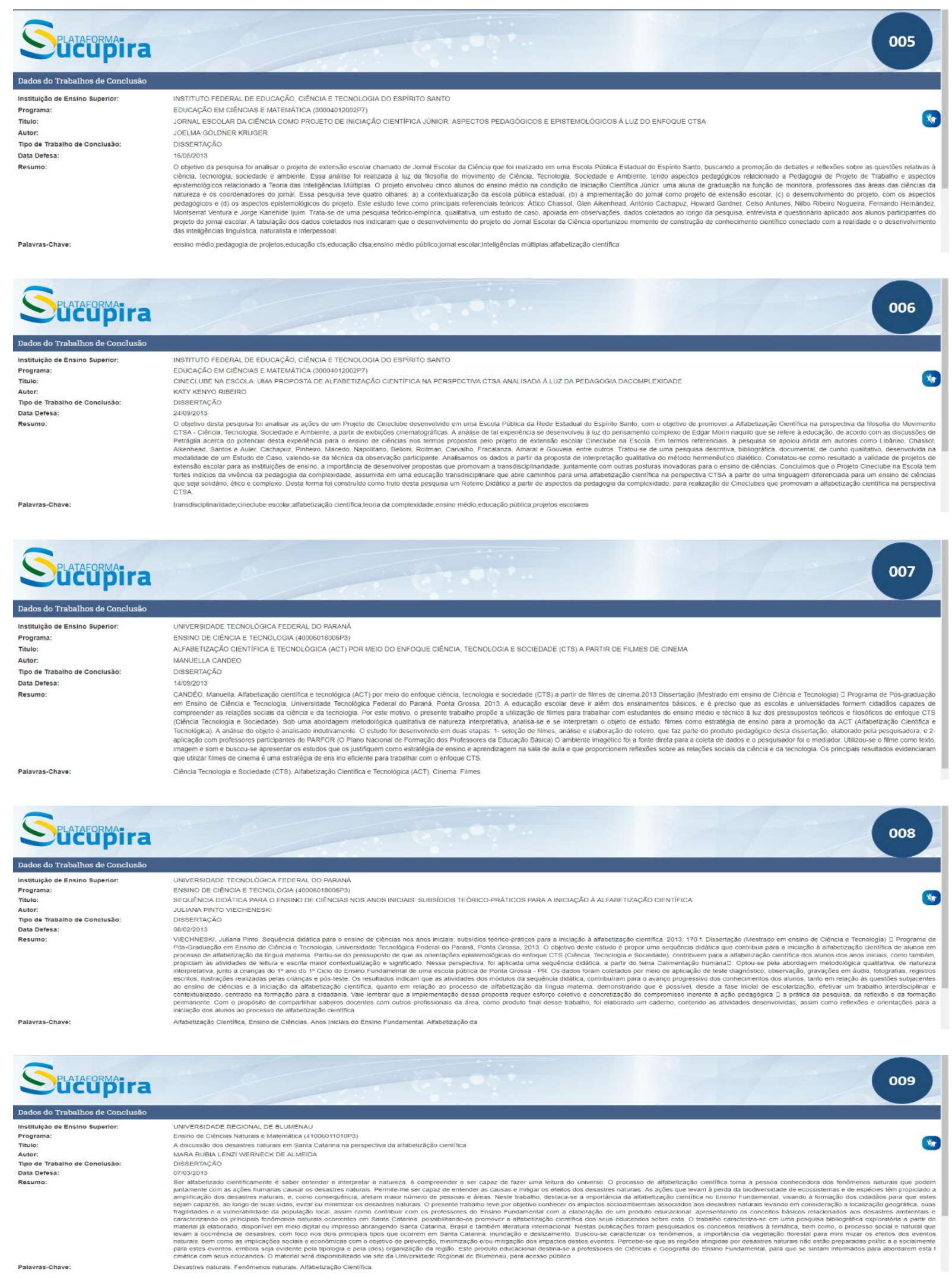

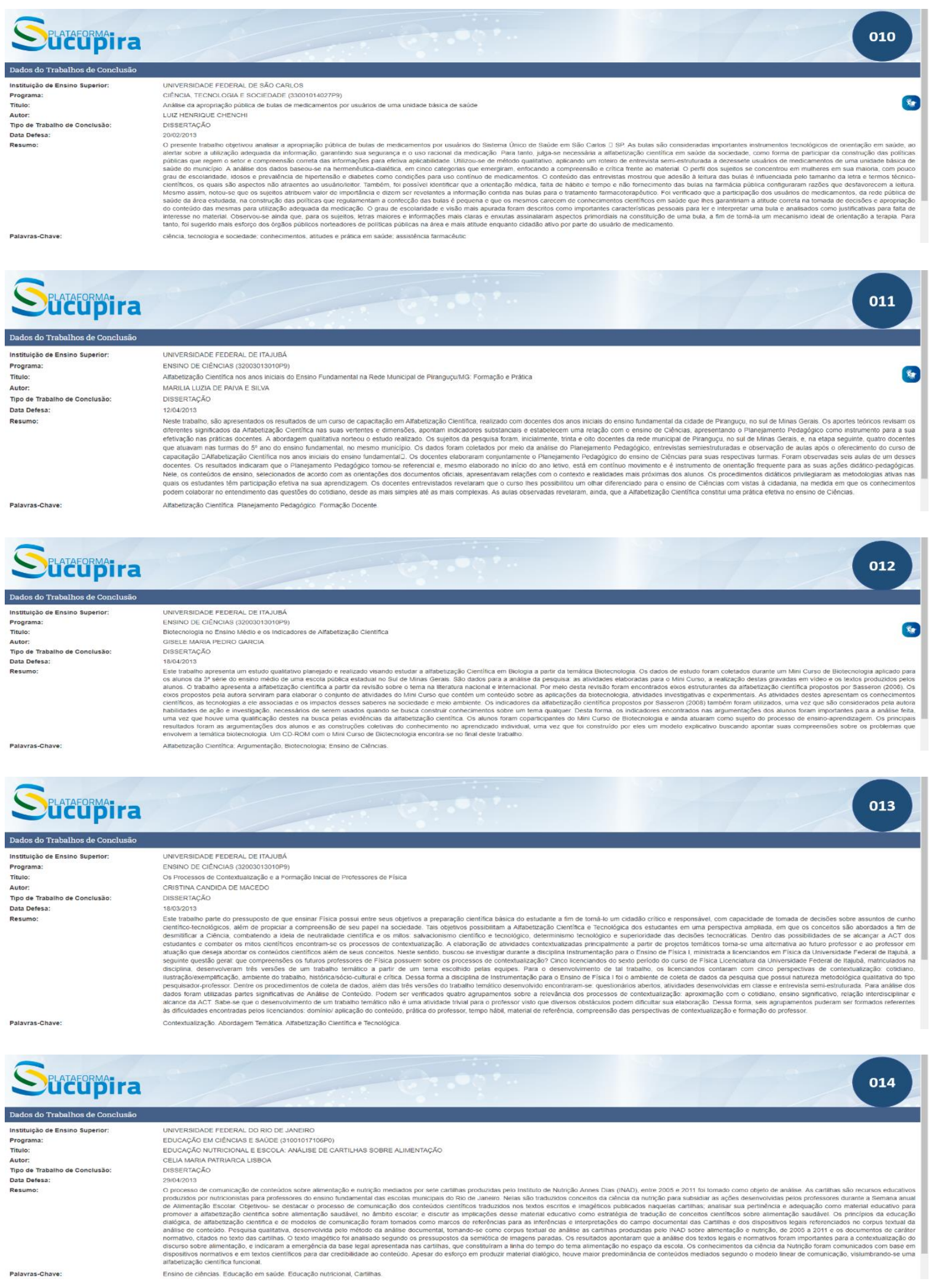

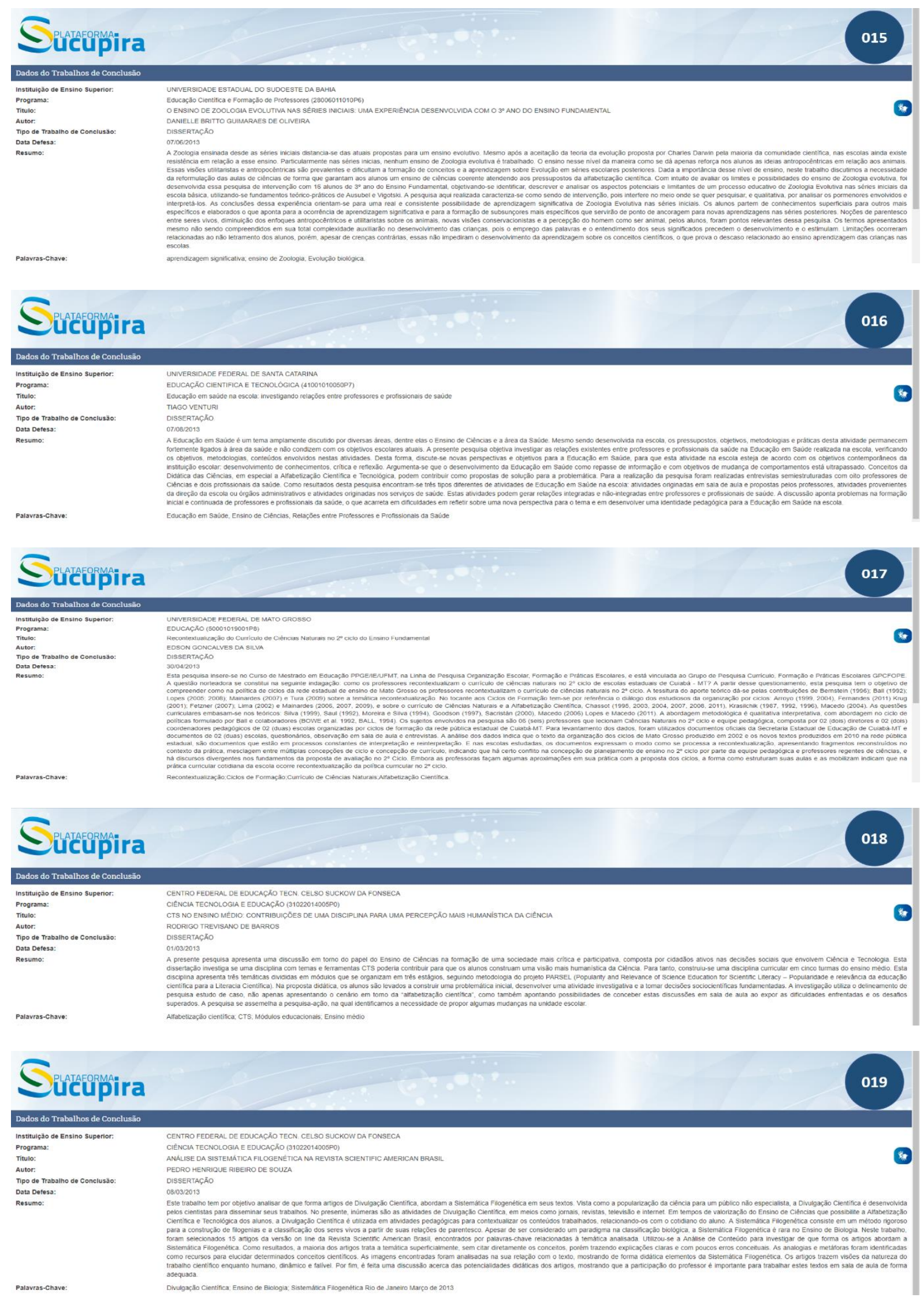

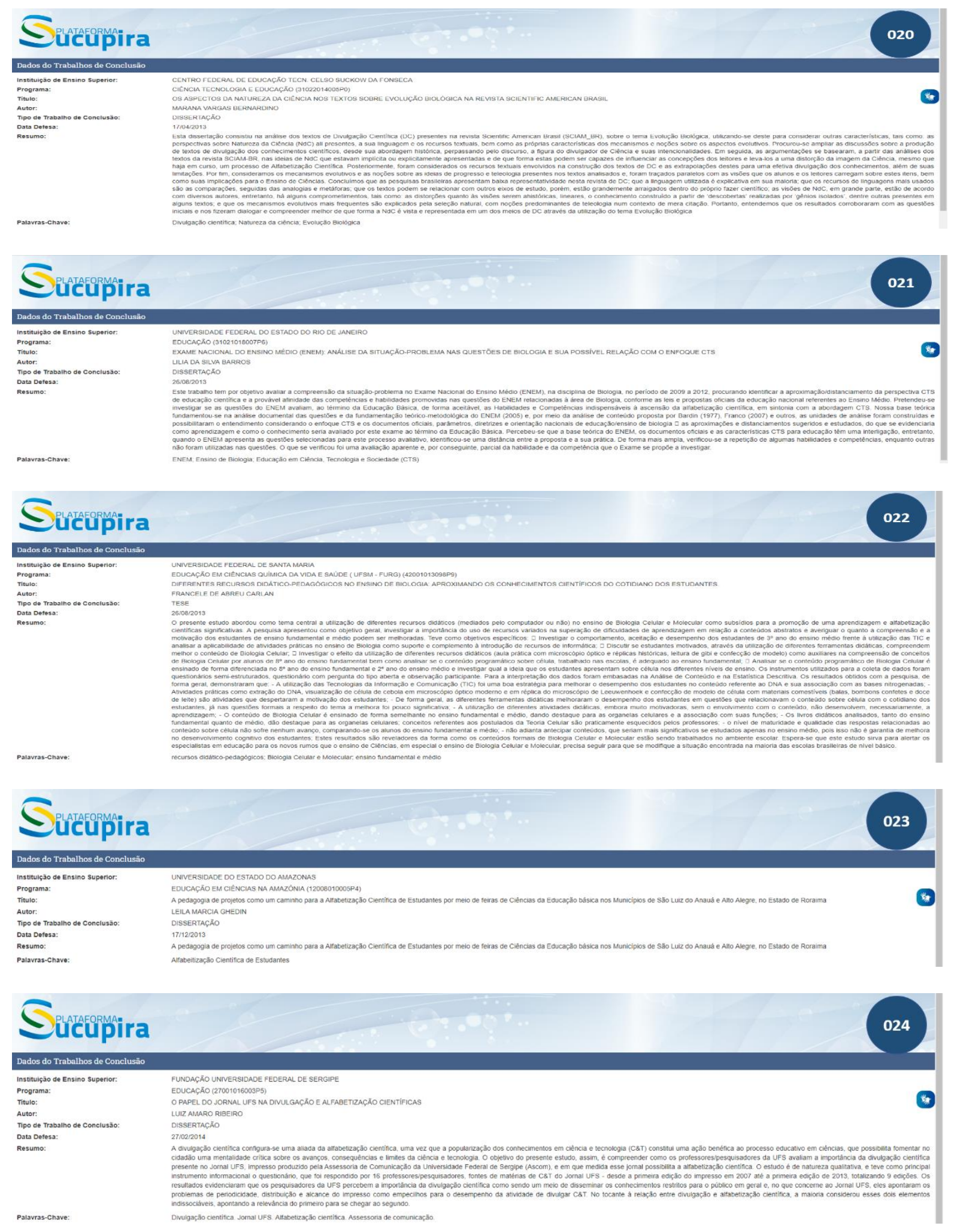

Vinícius Cipriano Andrade 

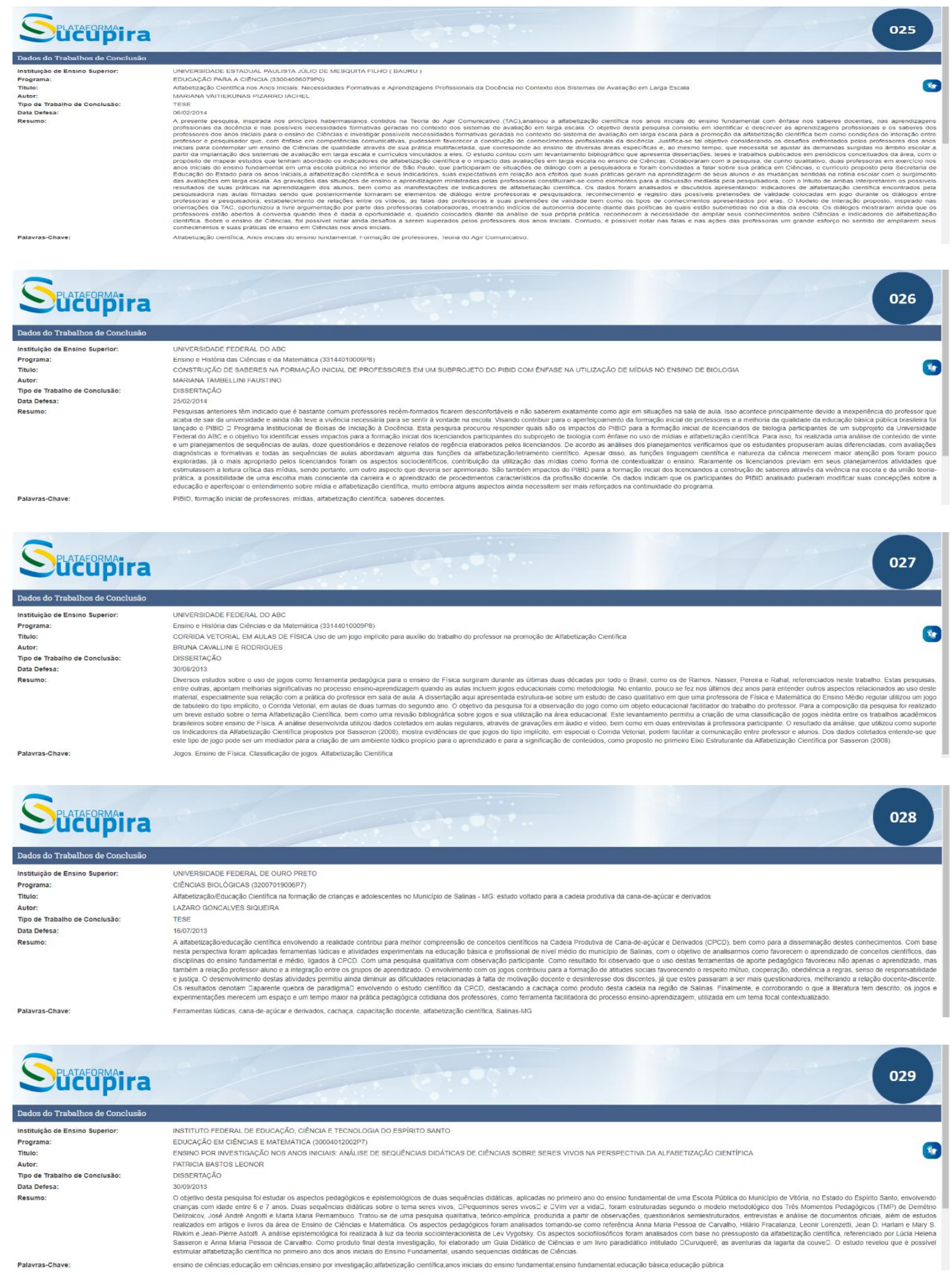

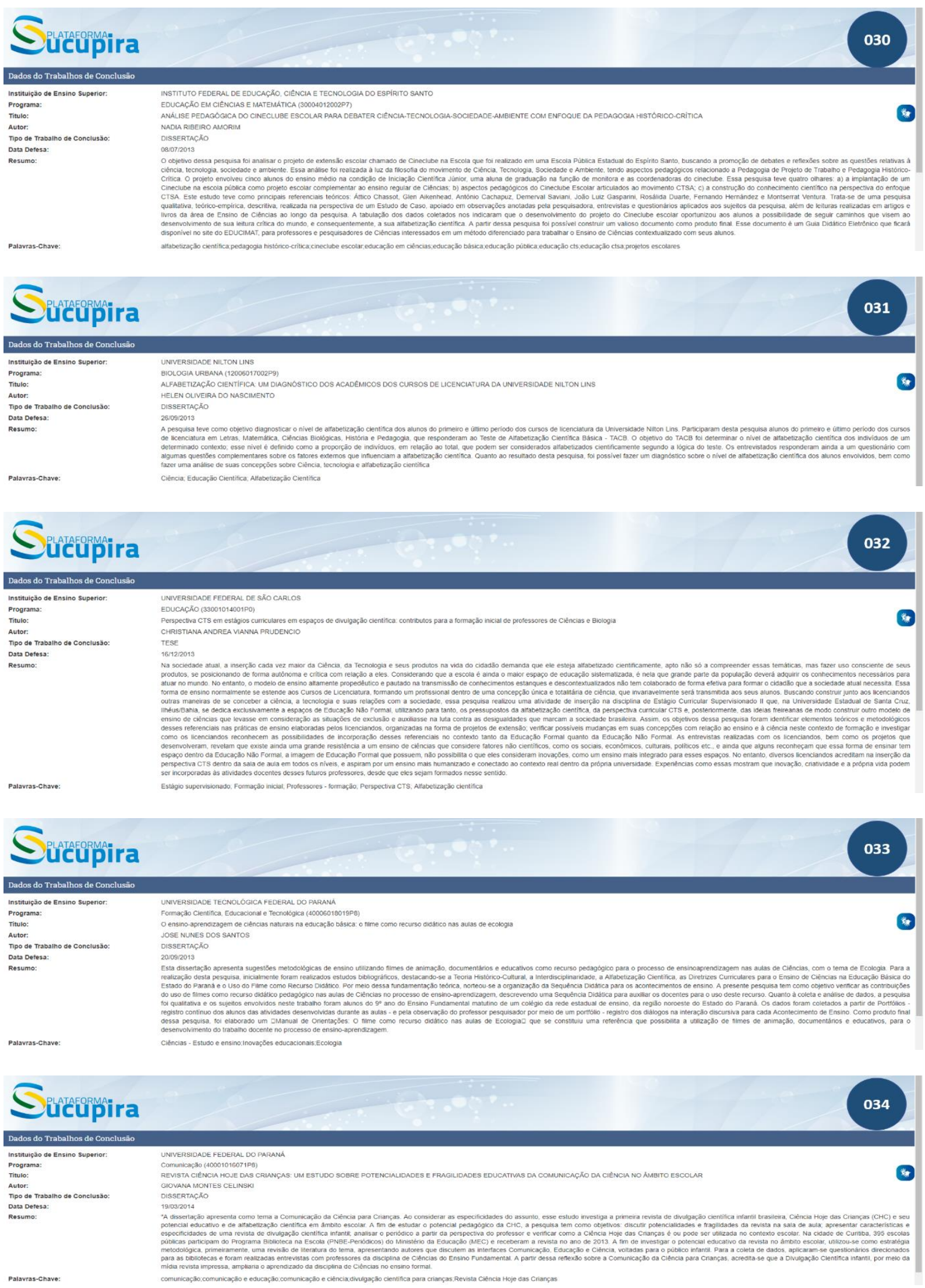

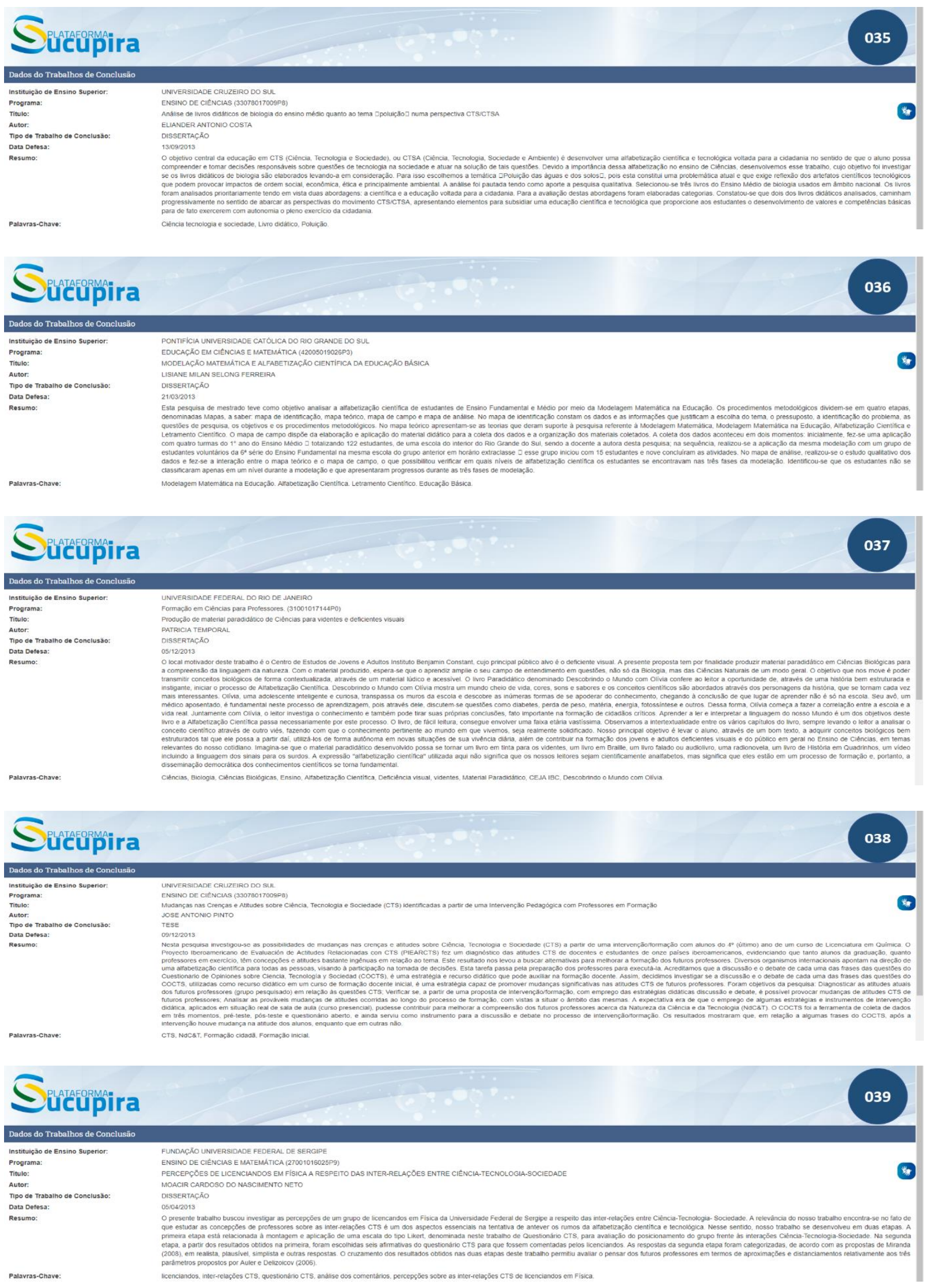

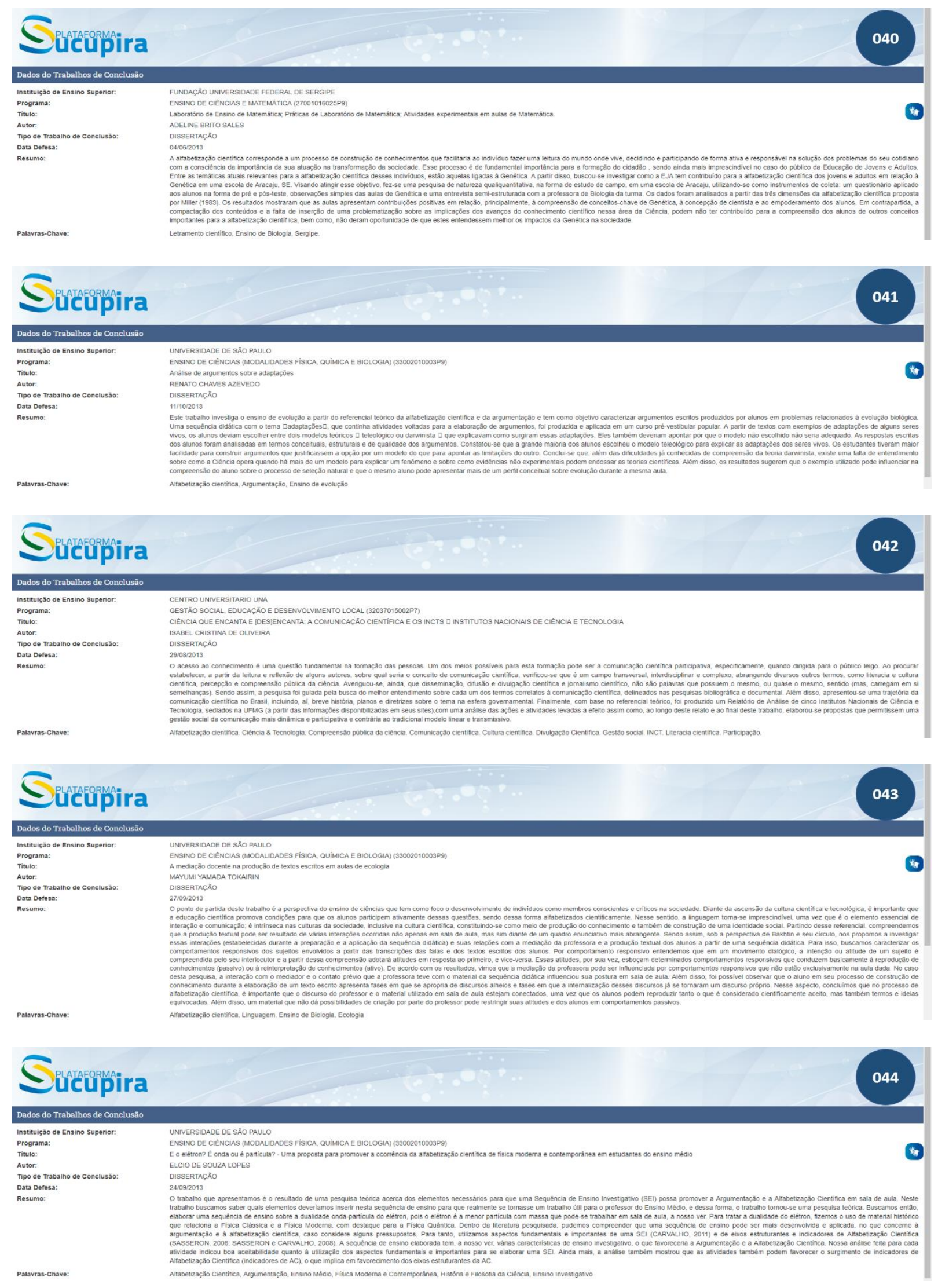

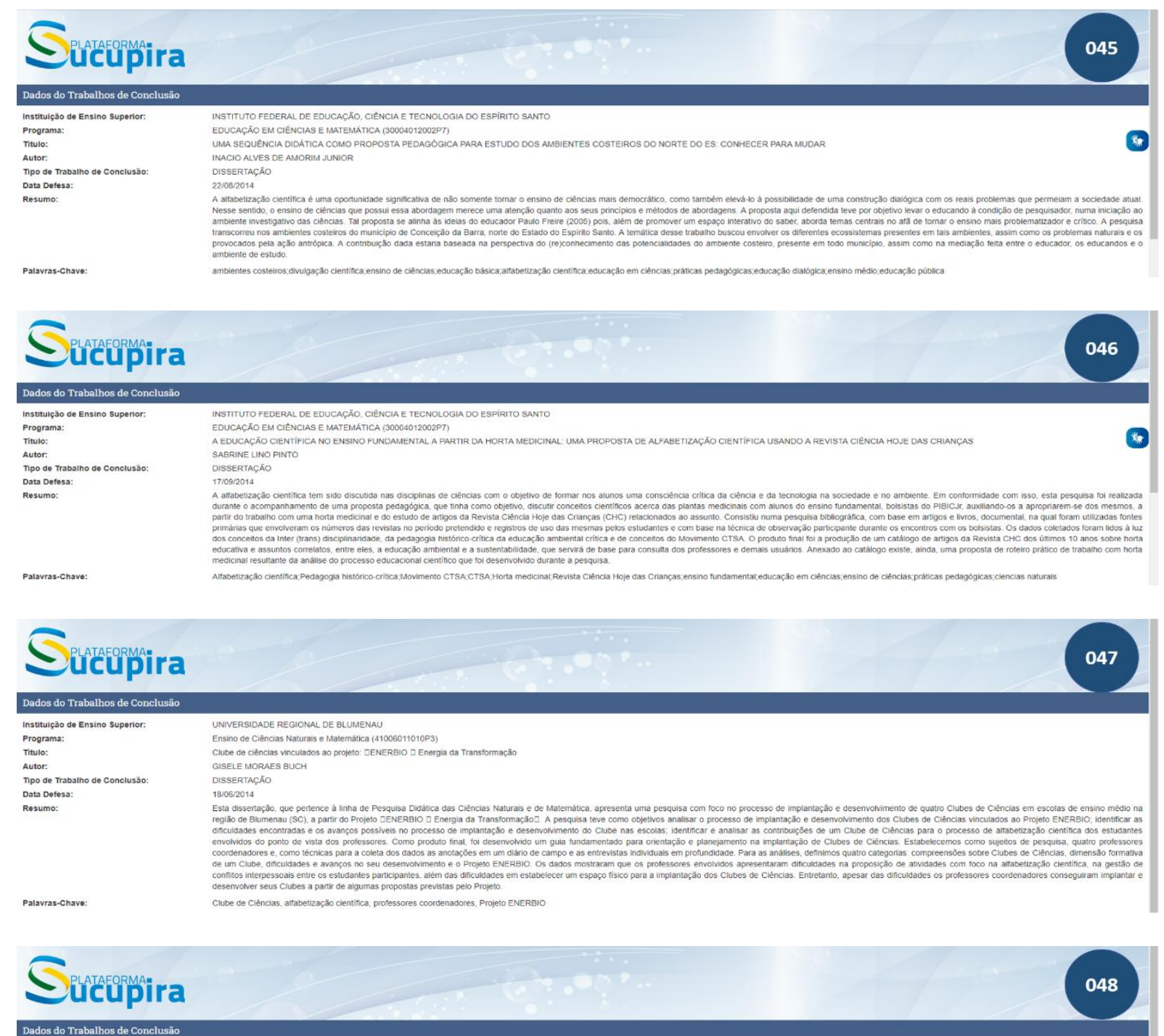

instructaba de Ensine Superior:

Program:

Autor:

Tipo de Trabaliho de Conclusa:

Data Defes:

EDUCACÁAO (32001010001PT)

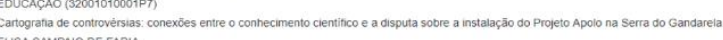

EUSA SAMPAIO DE FARIA

DISSERTACAO

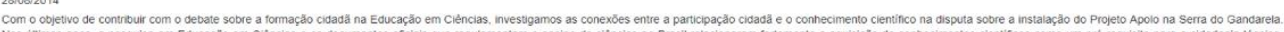

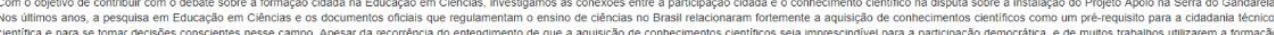

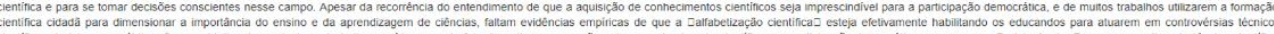

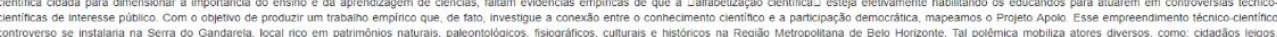

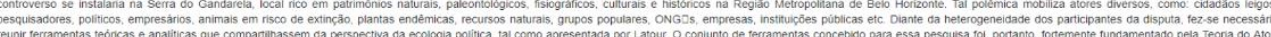

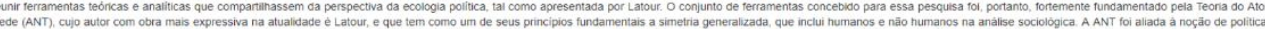

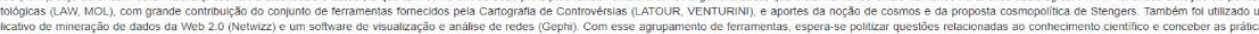

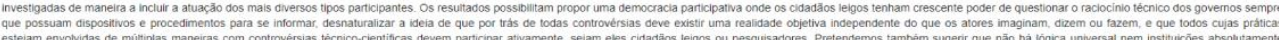

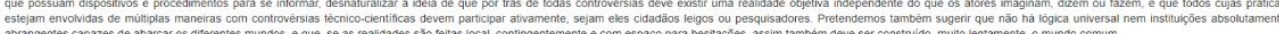

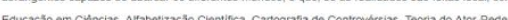



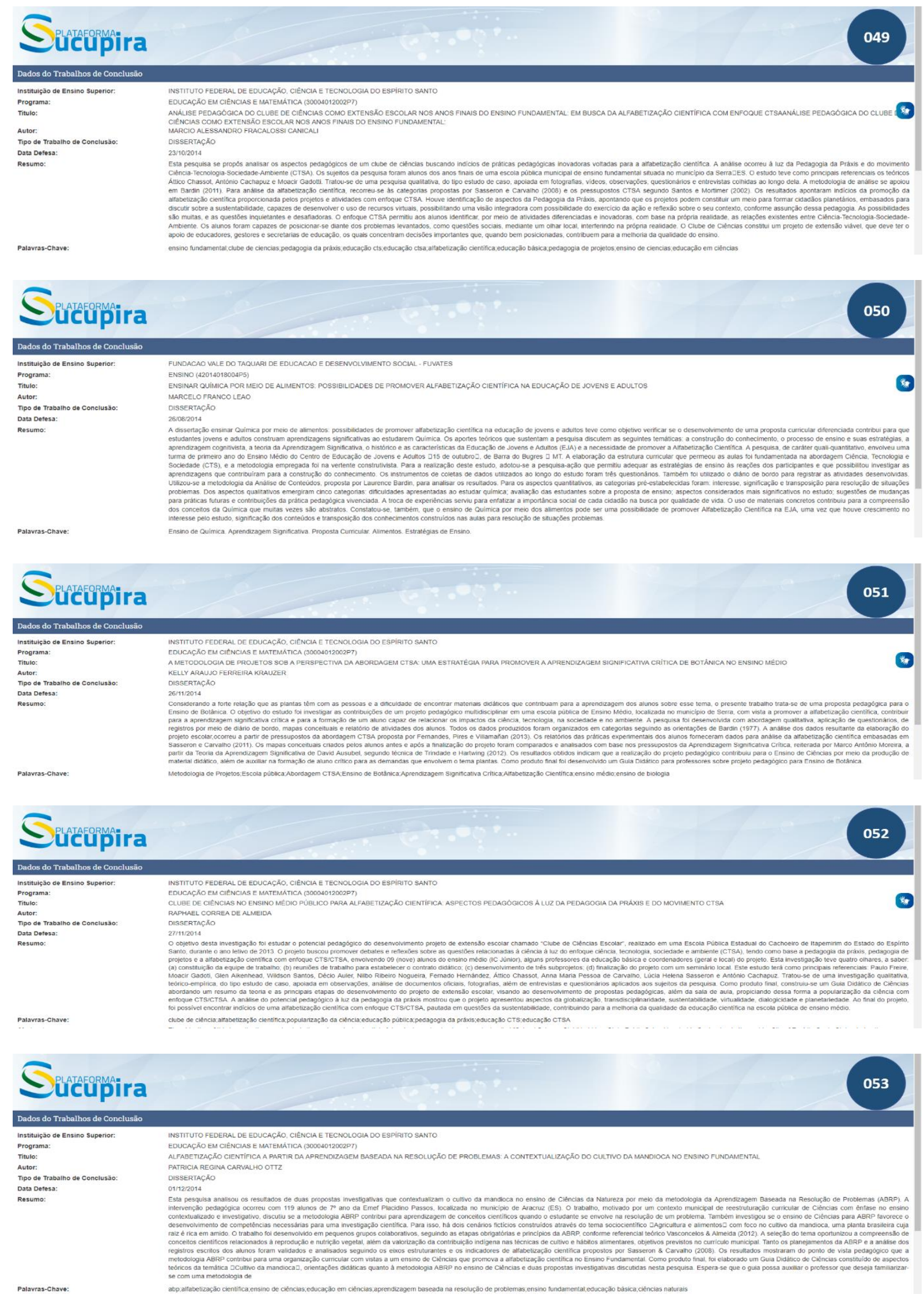

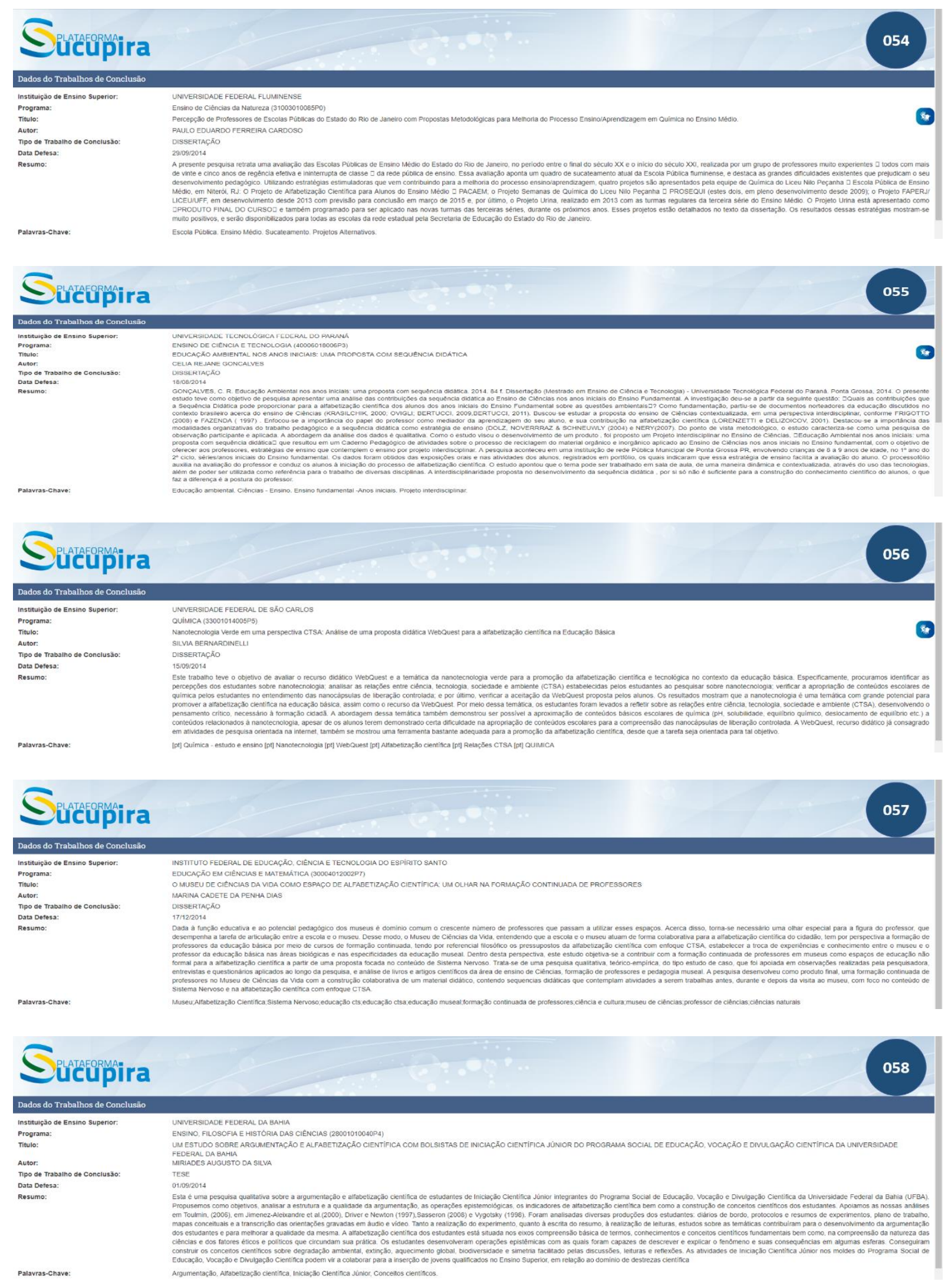

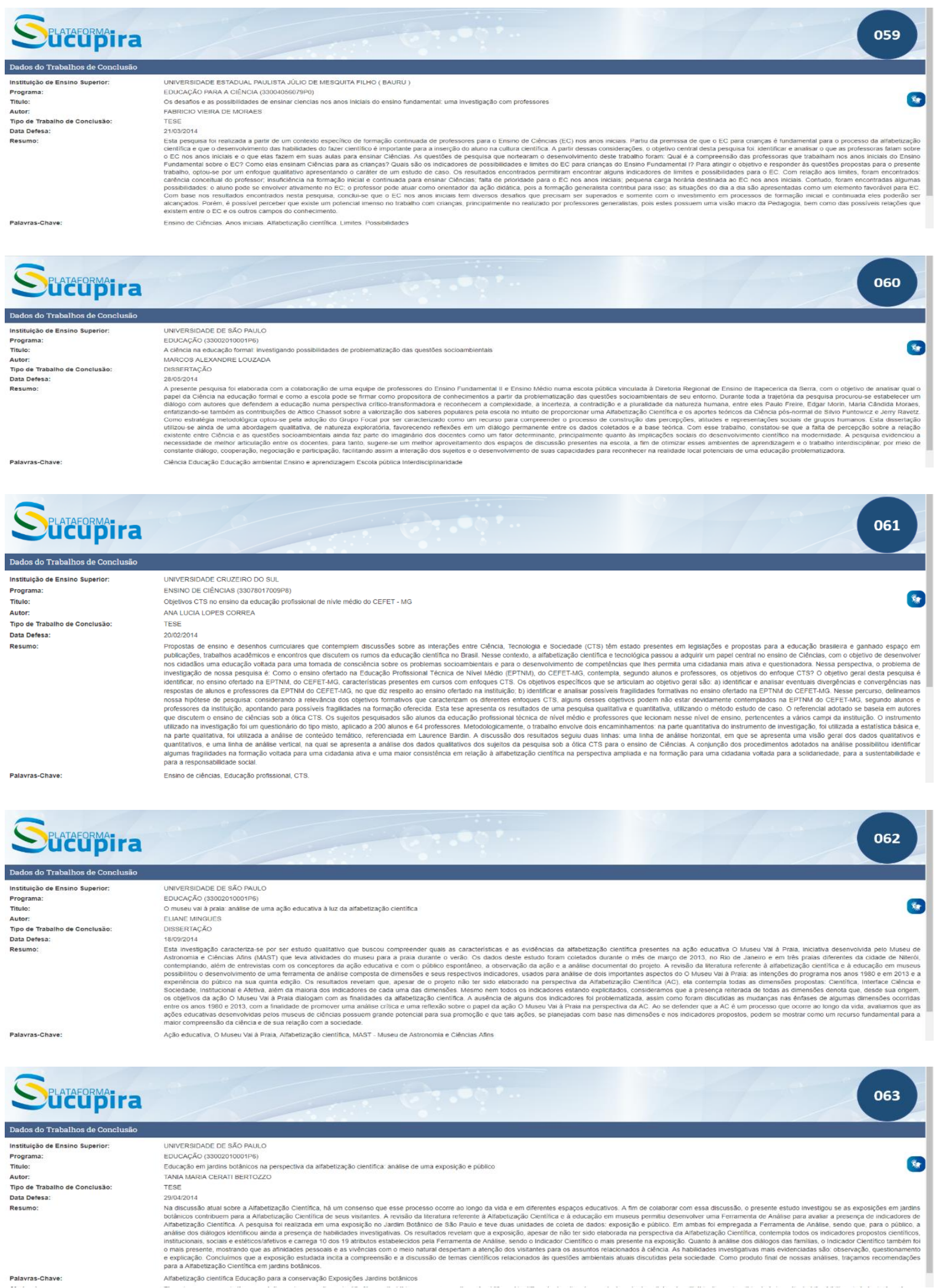

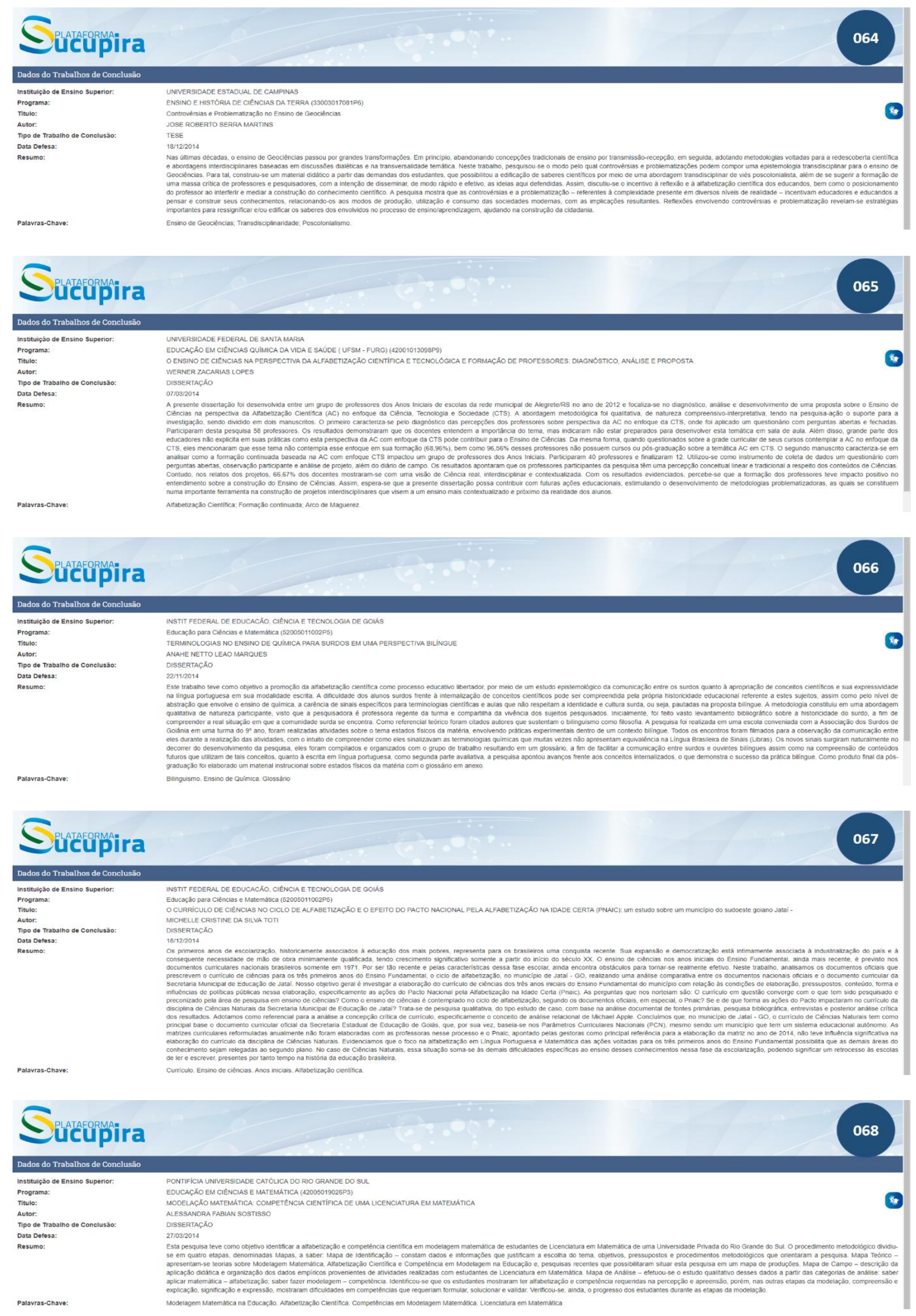

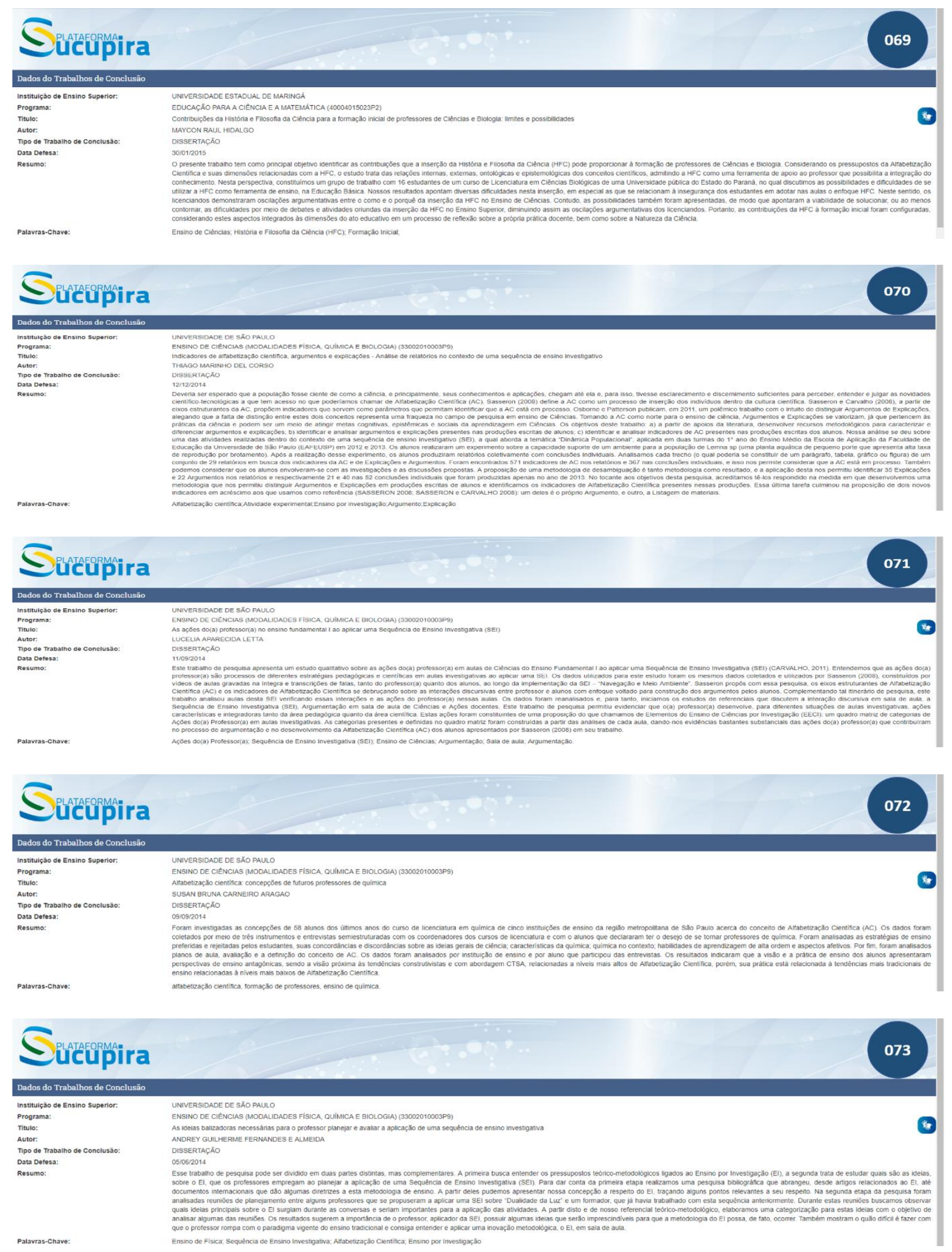

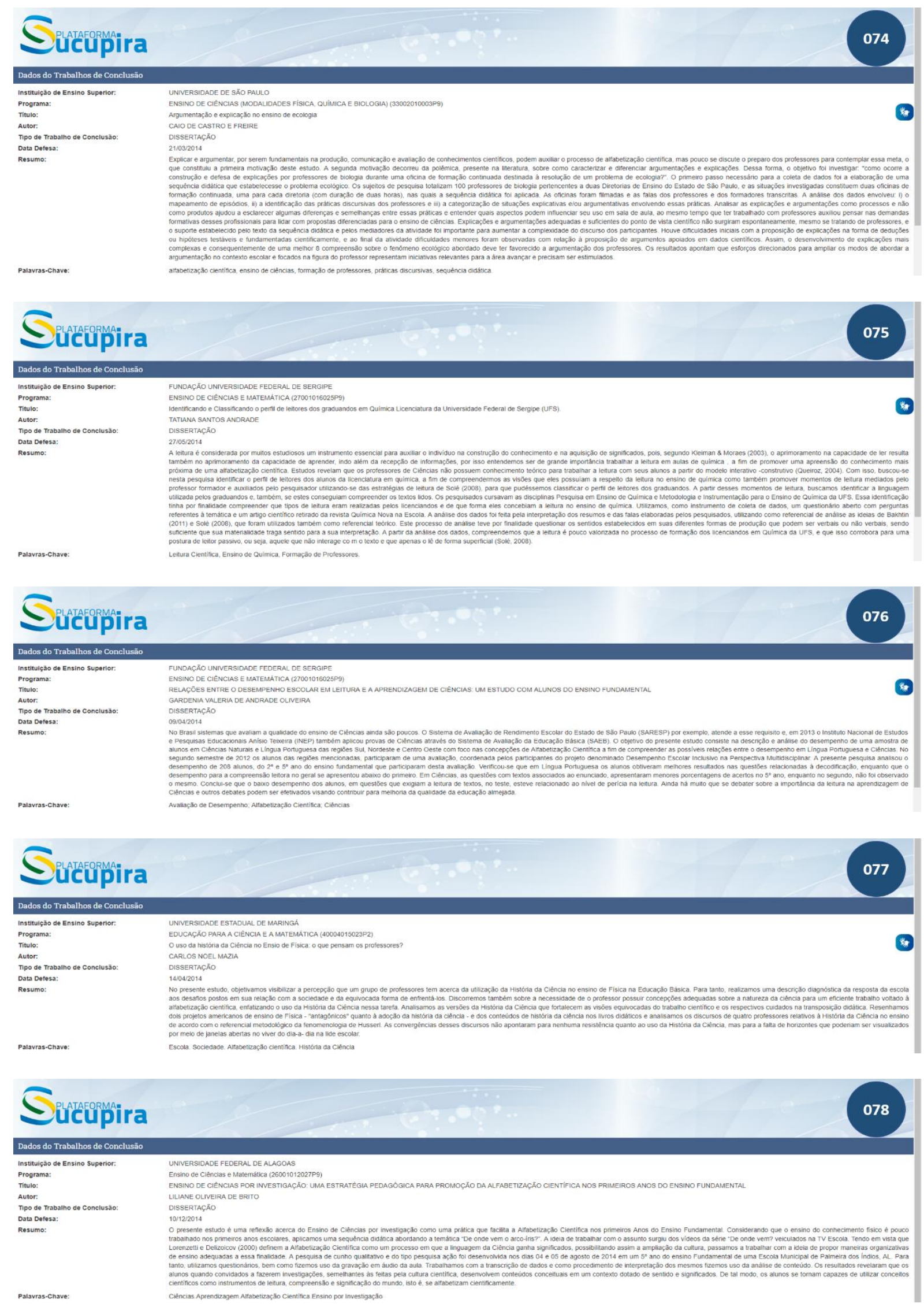

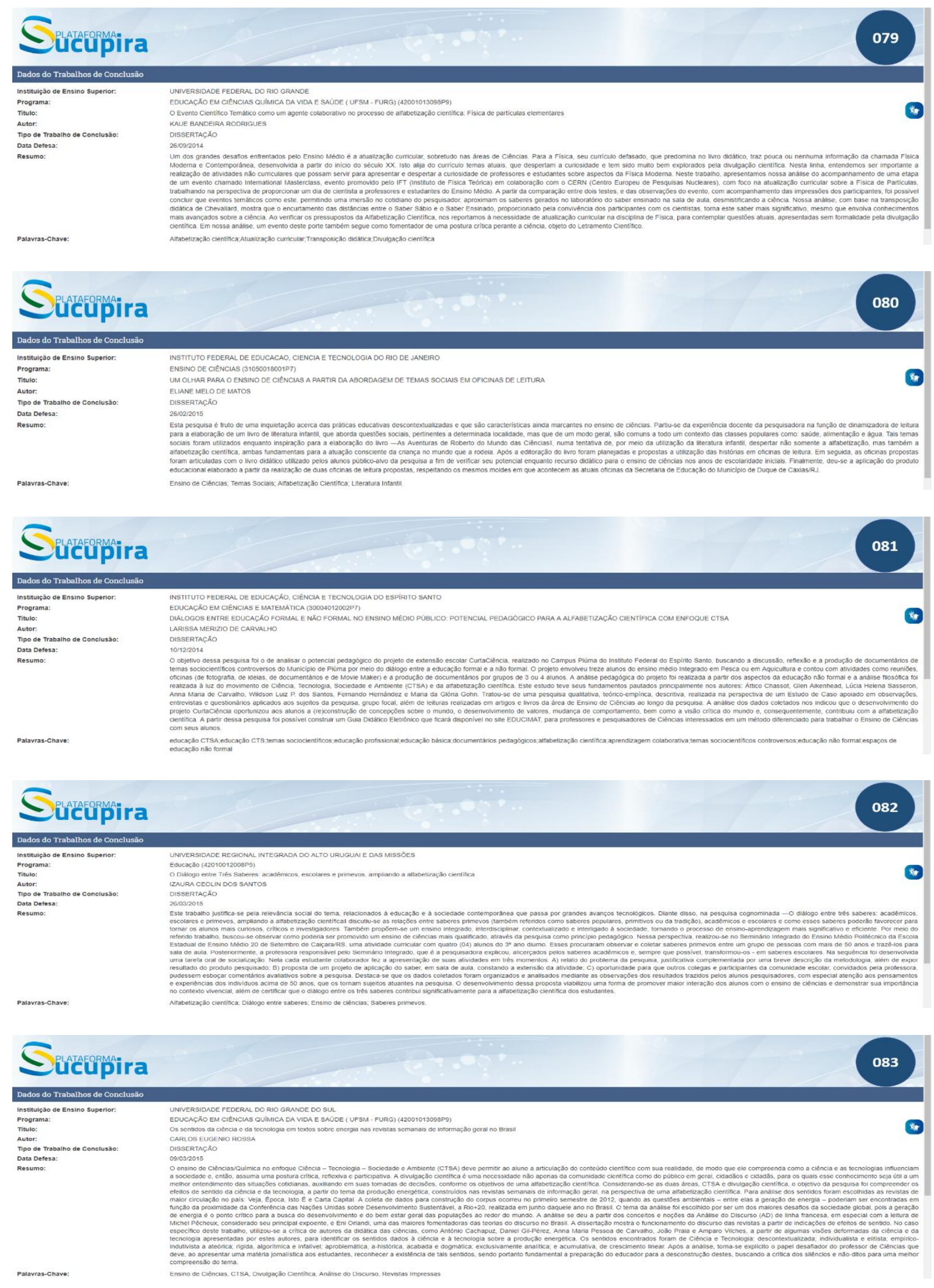

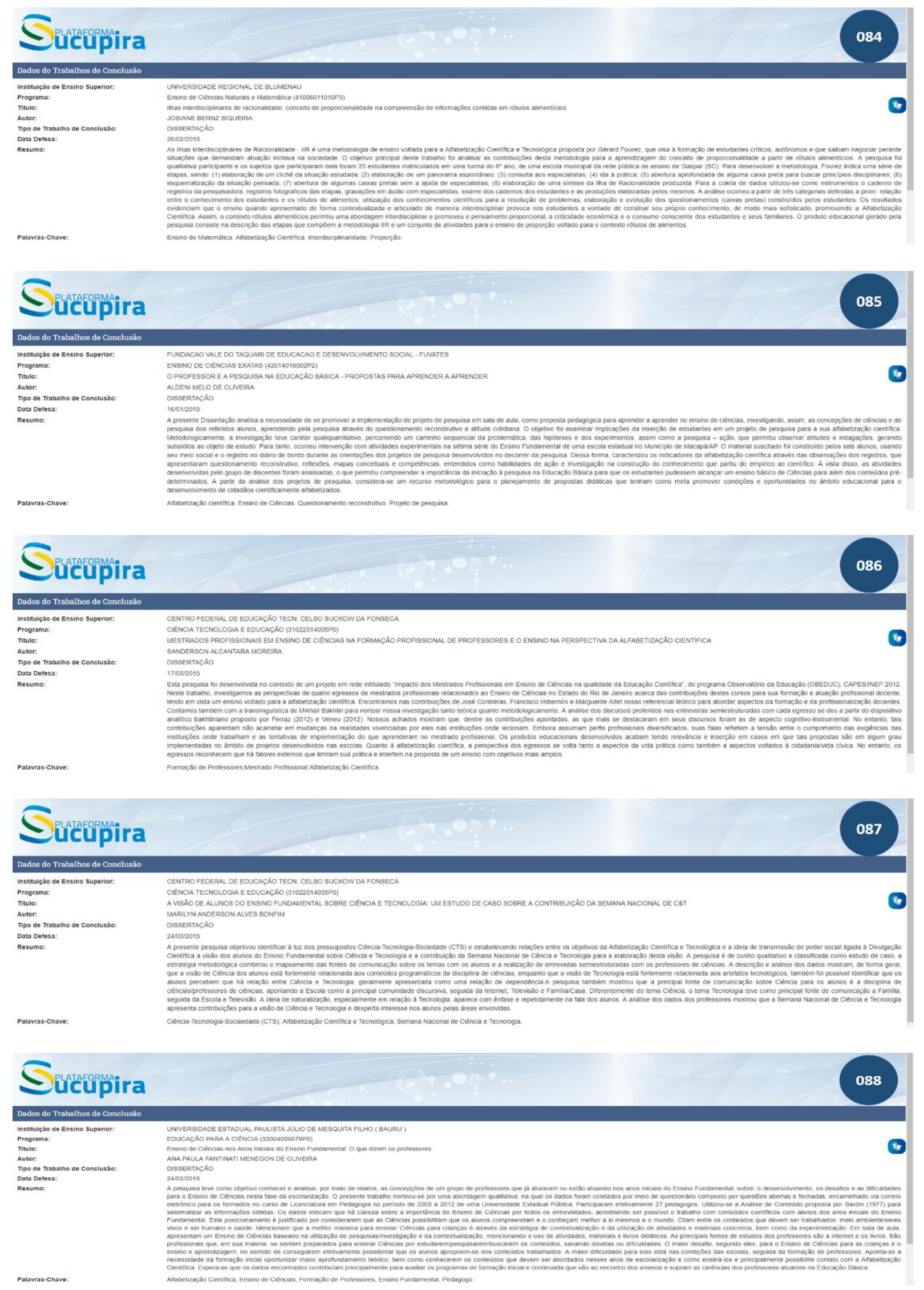

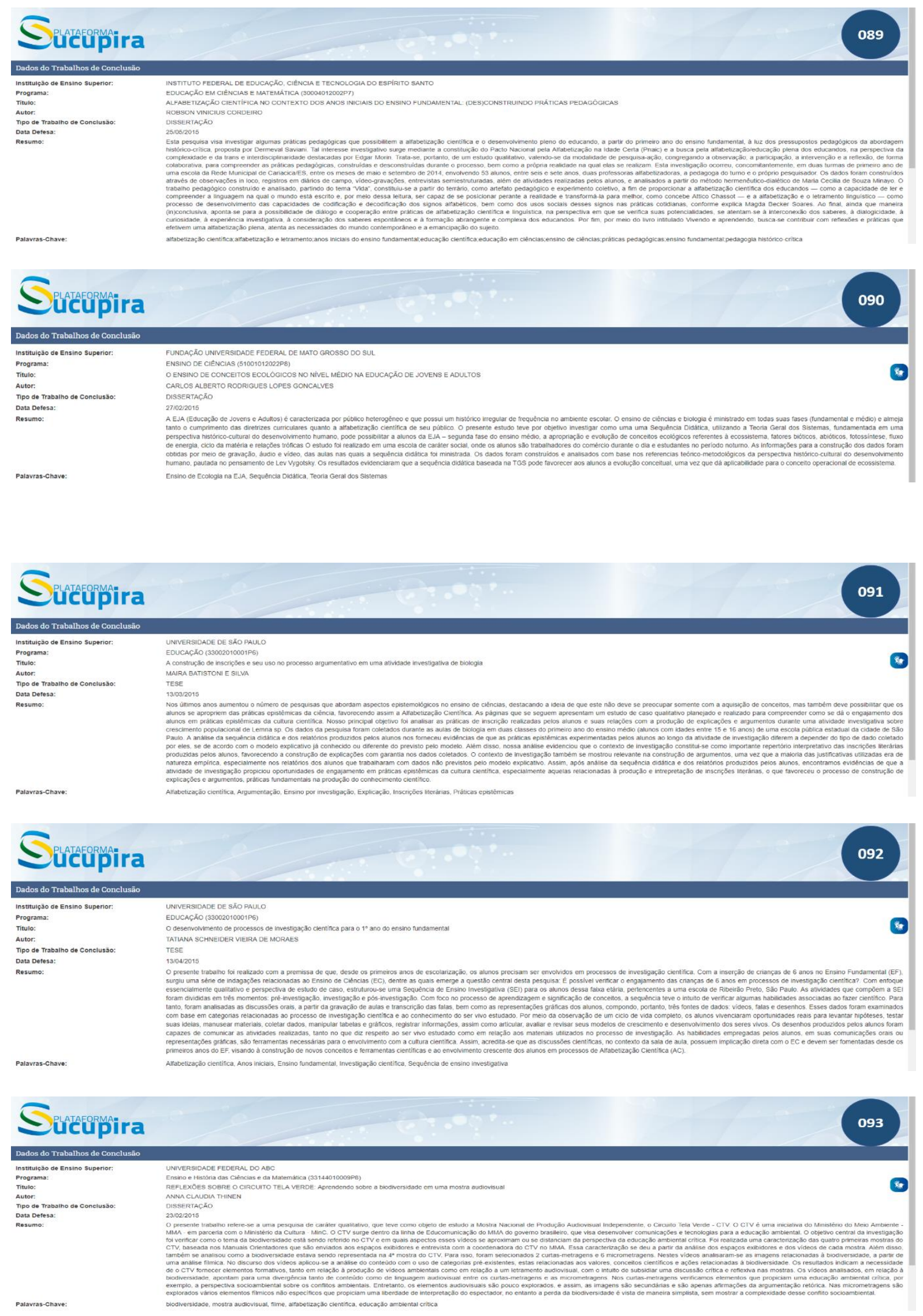

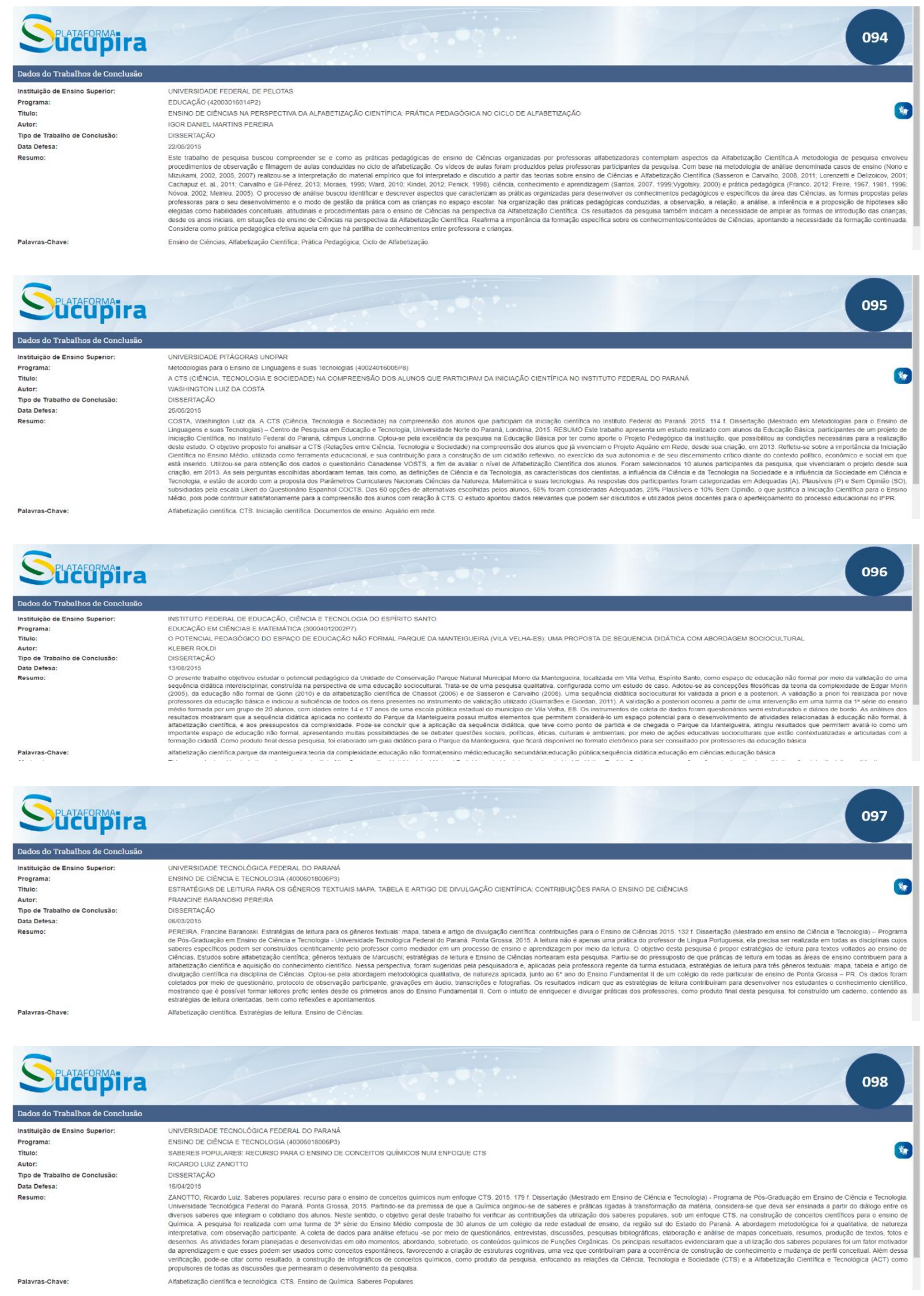

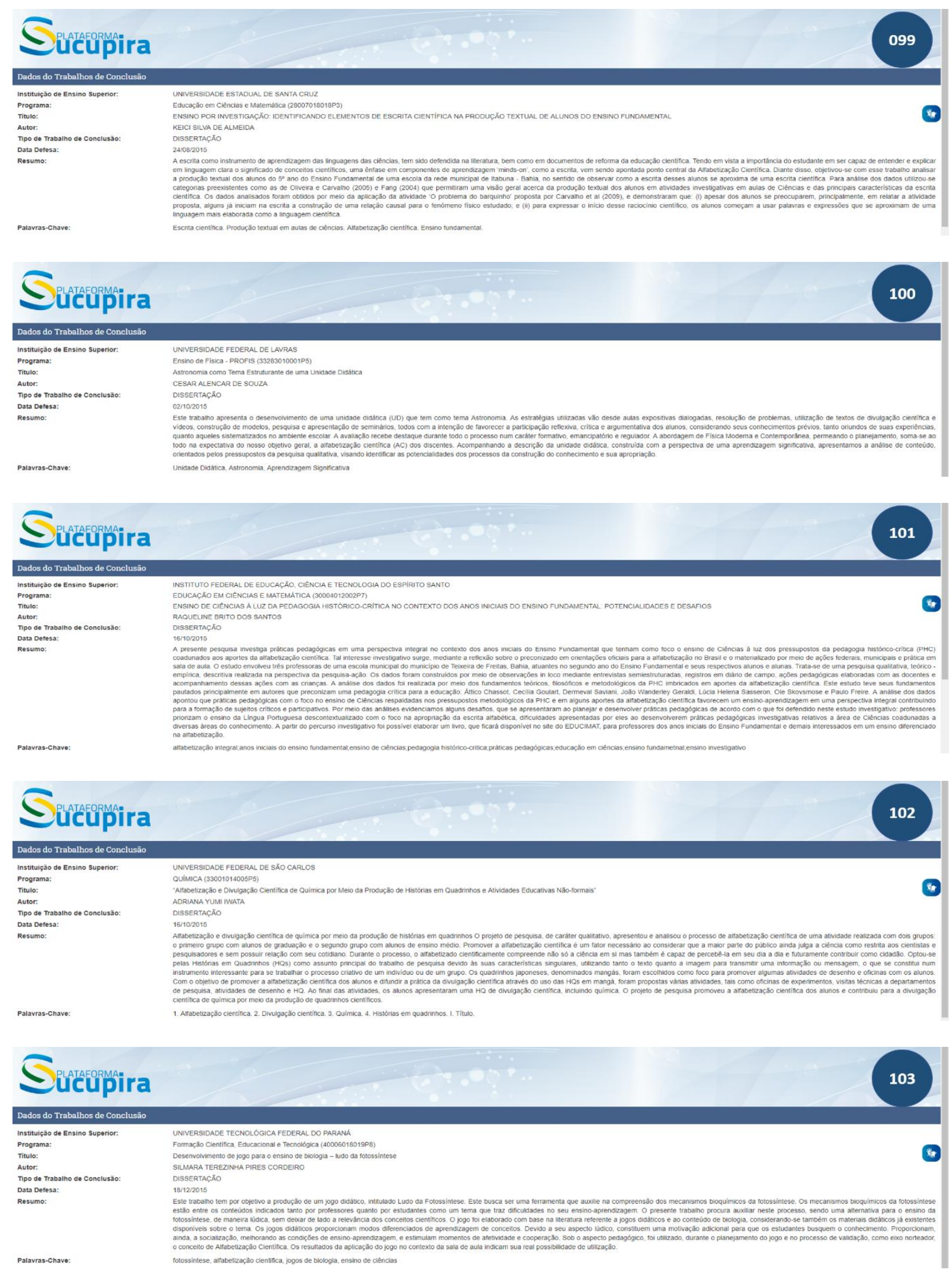

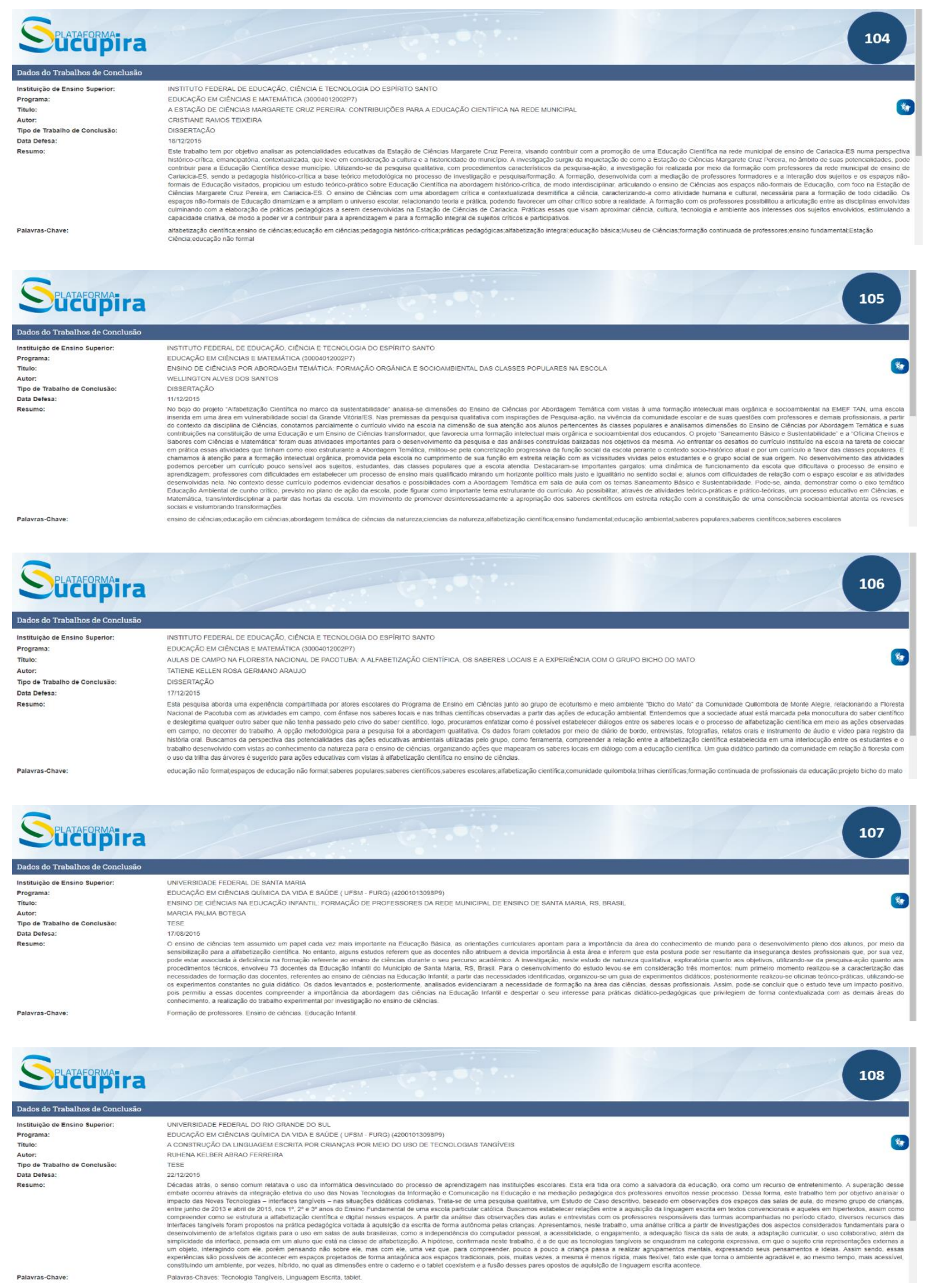

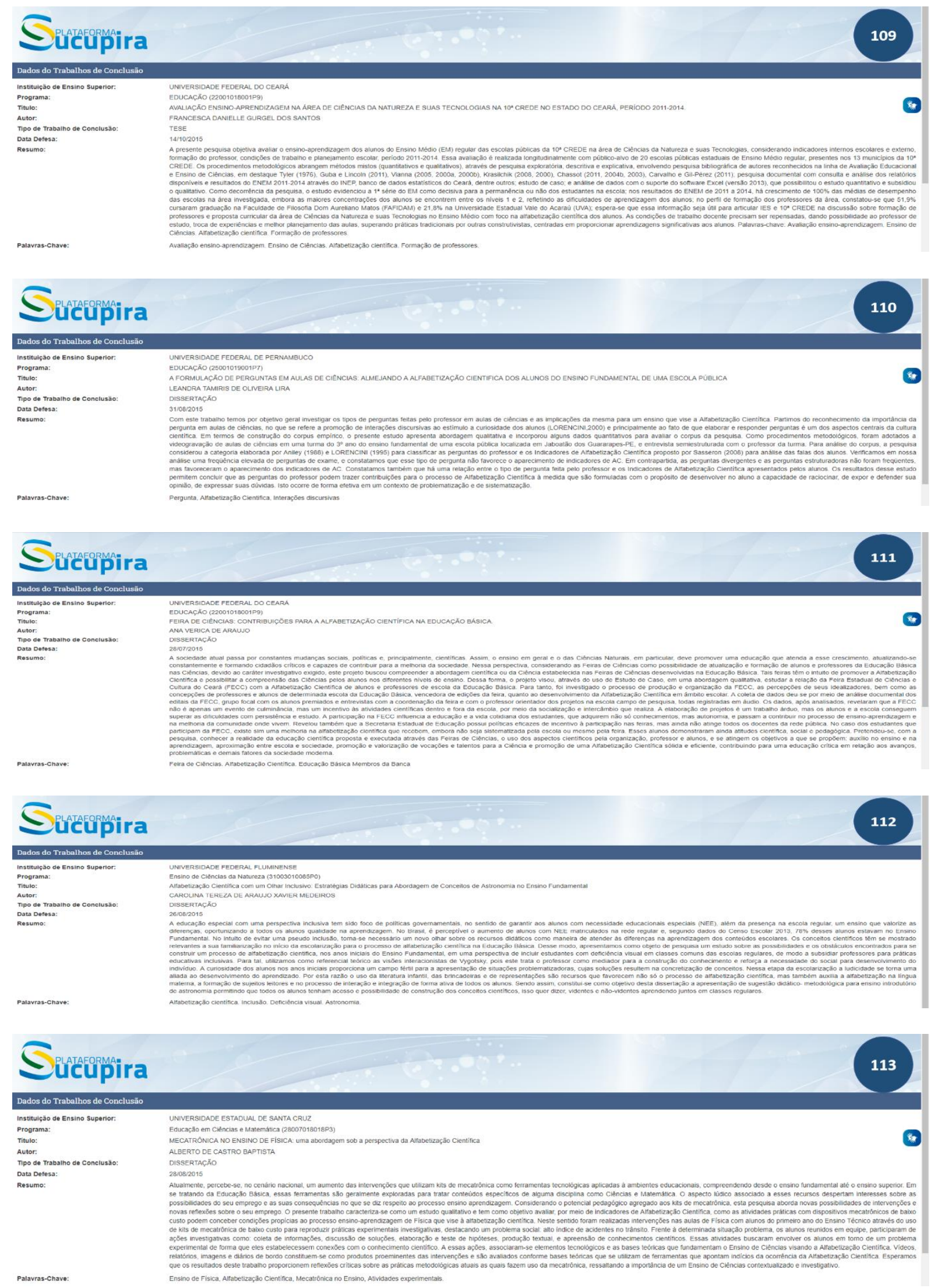

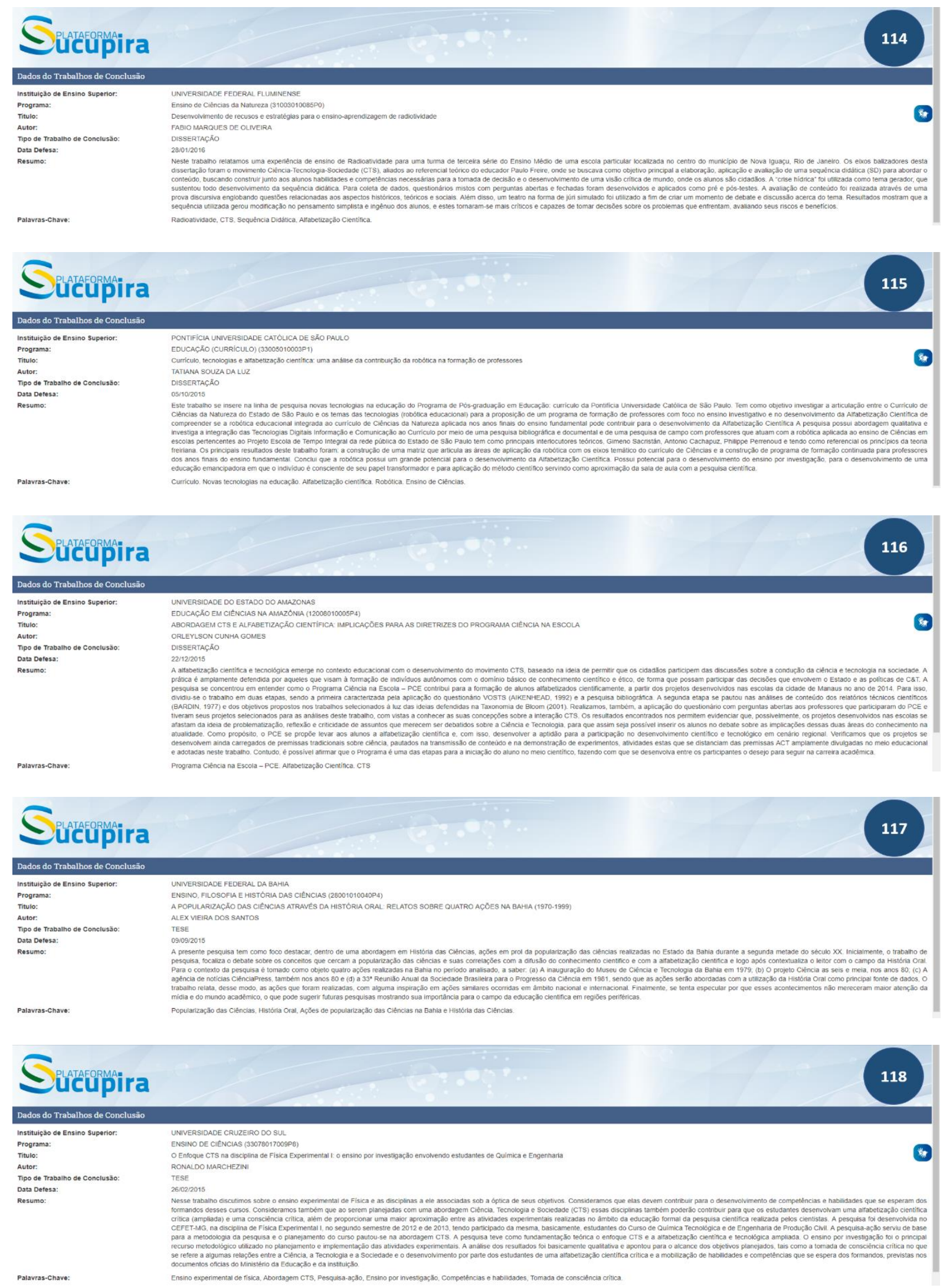

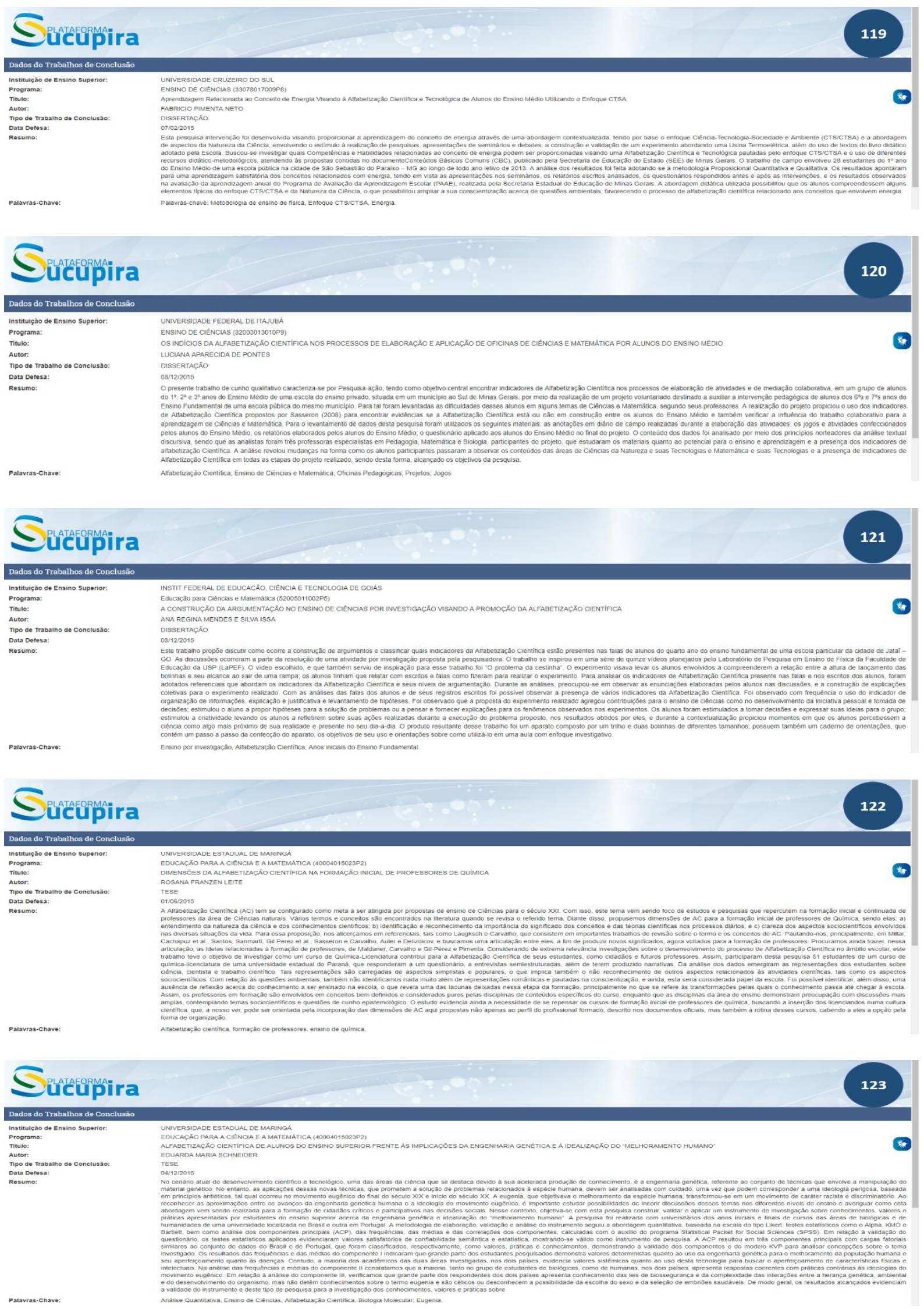

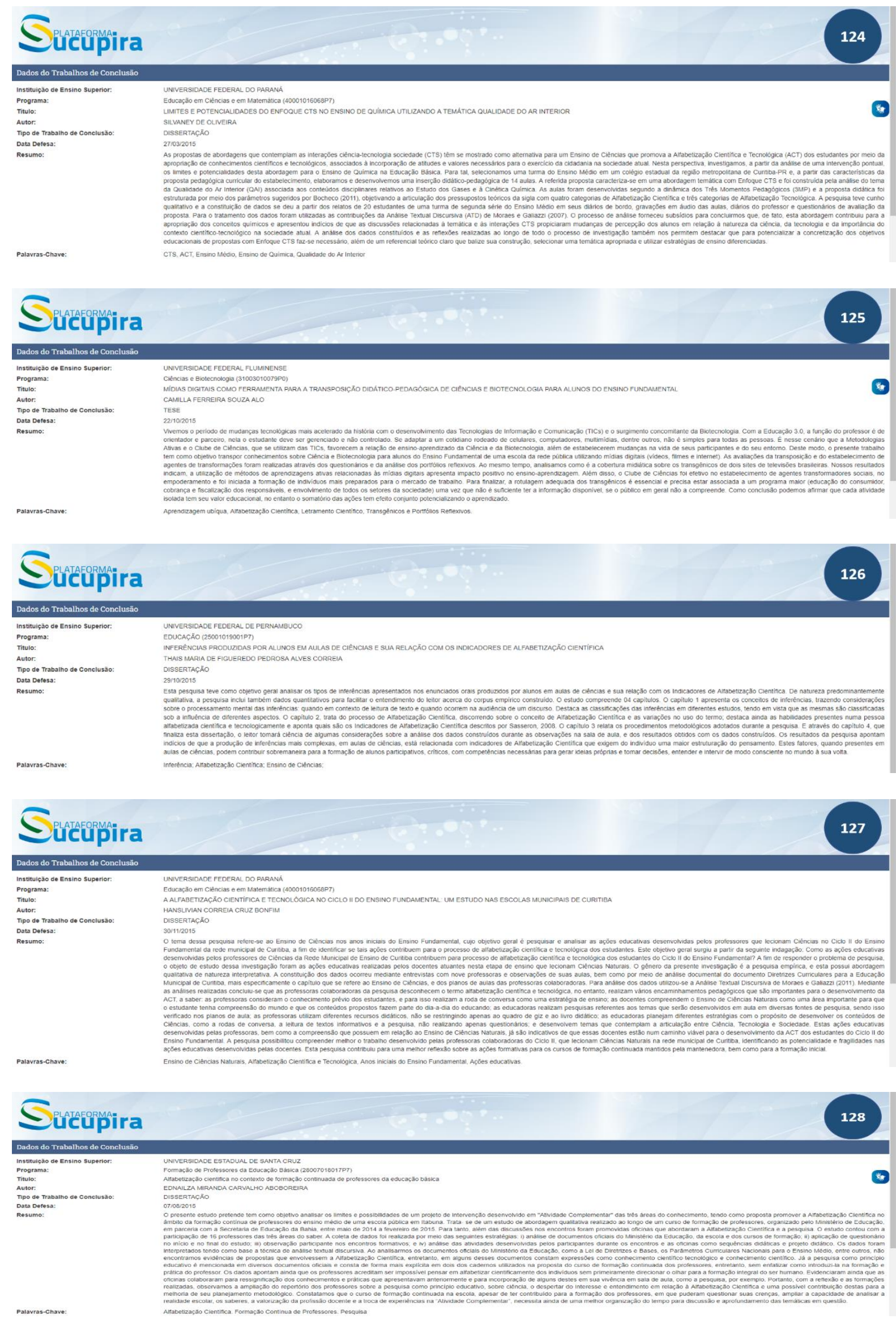

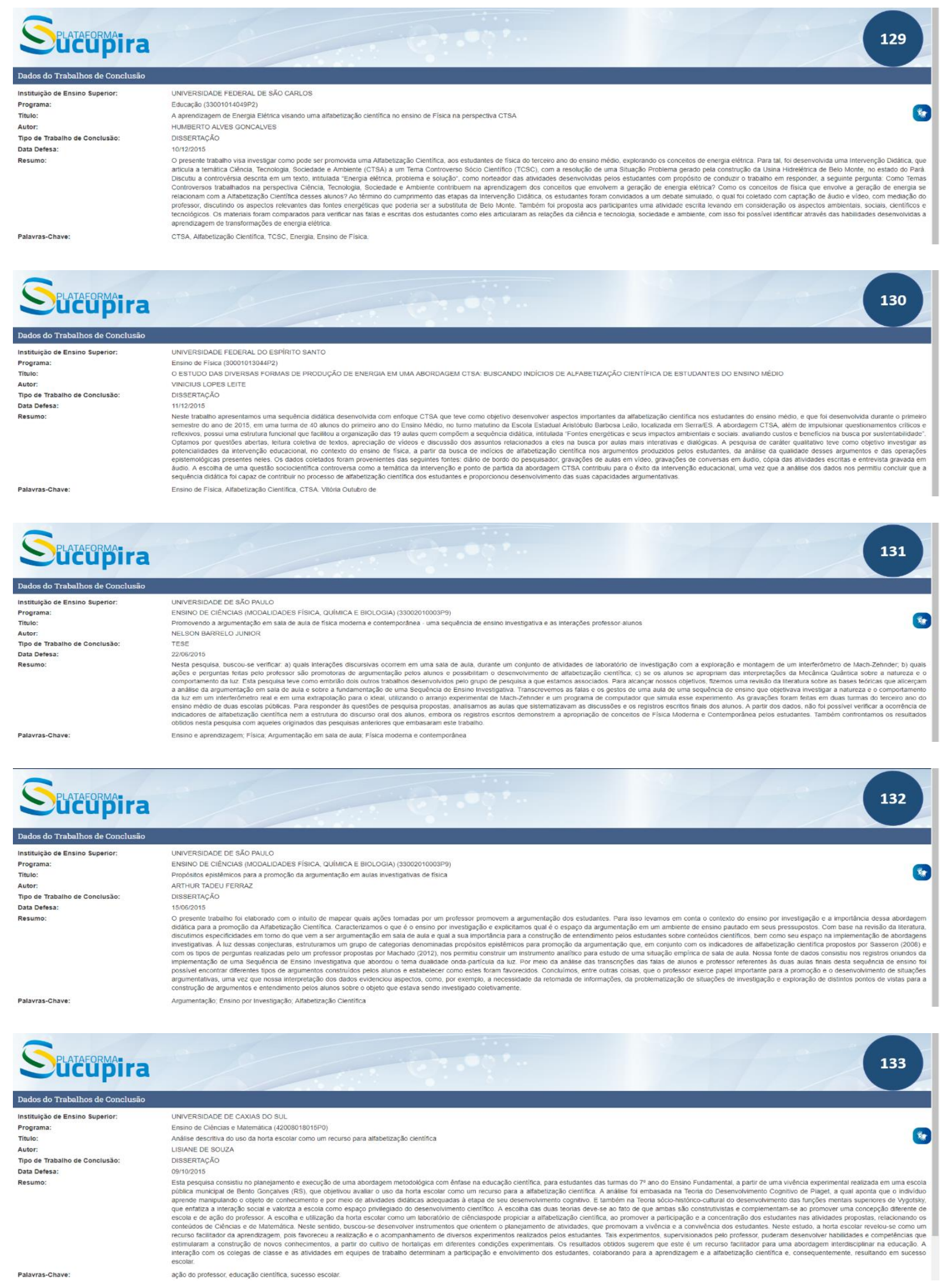

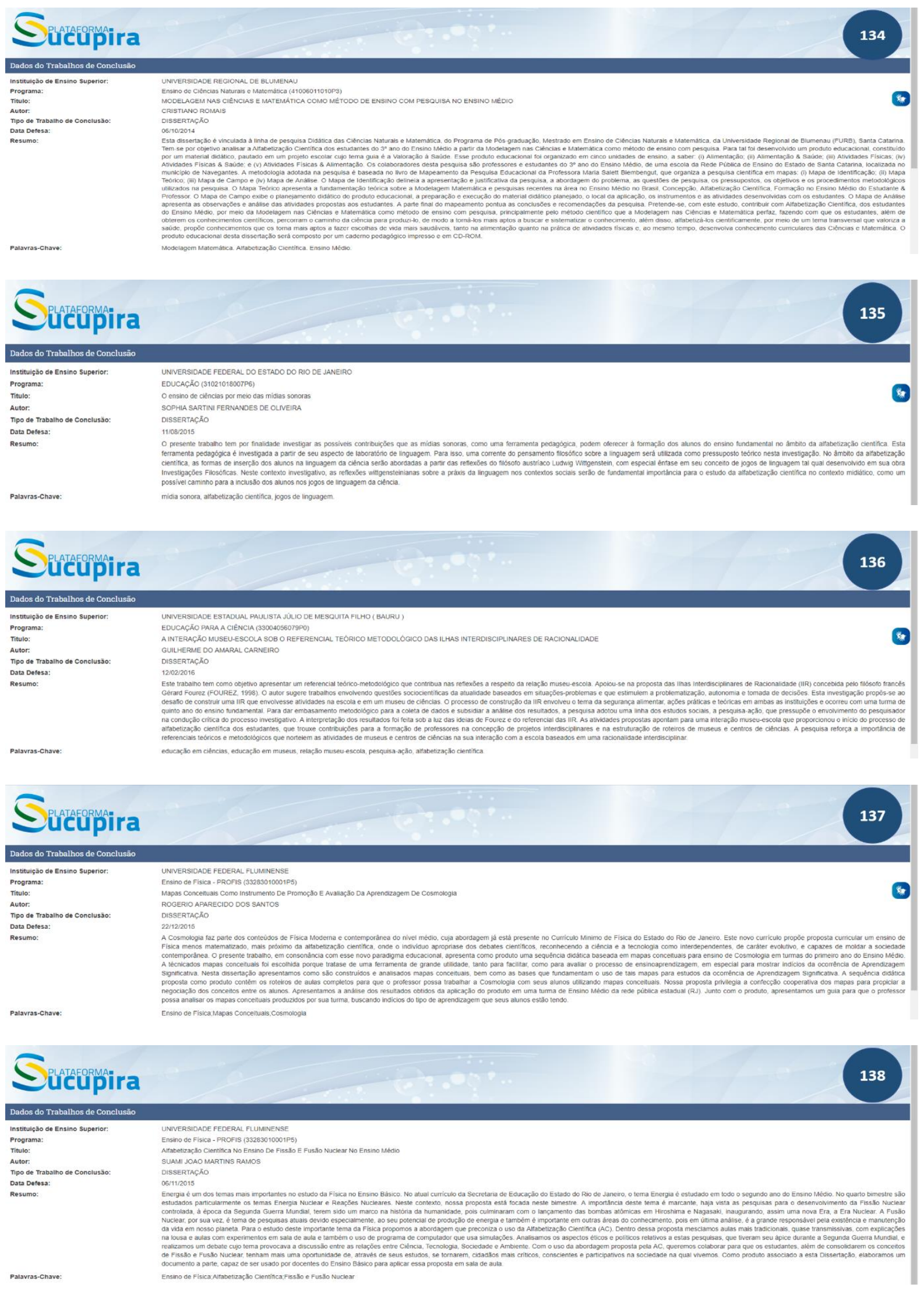

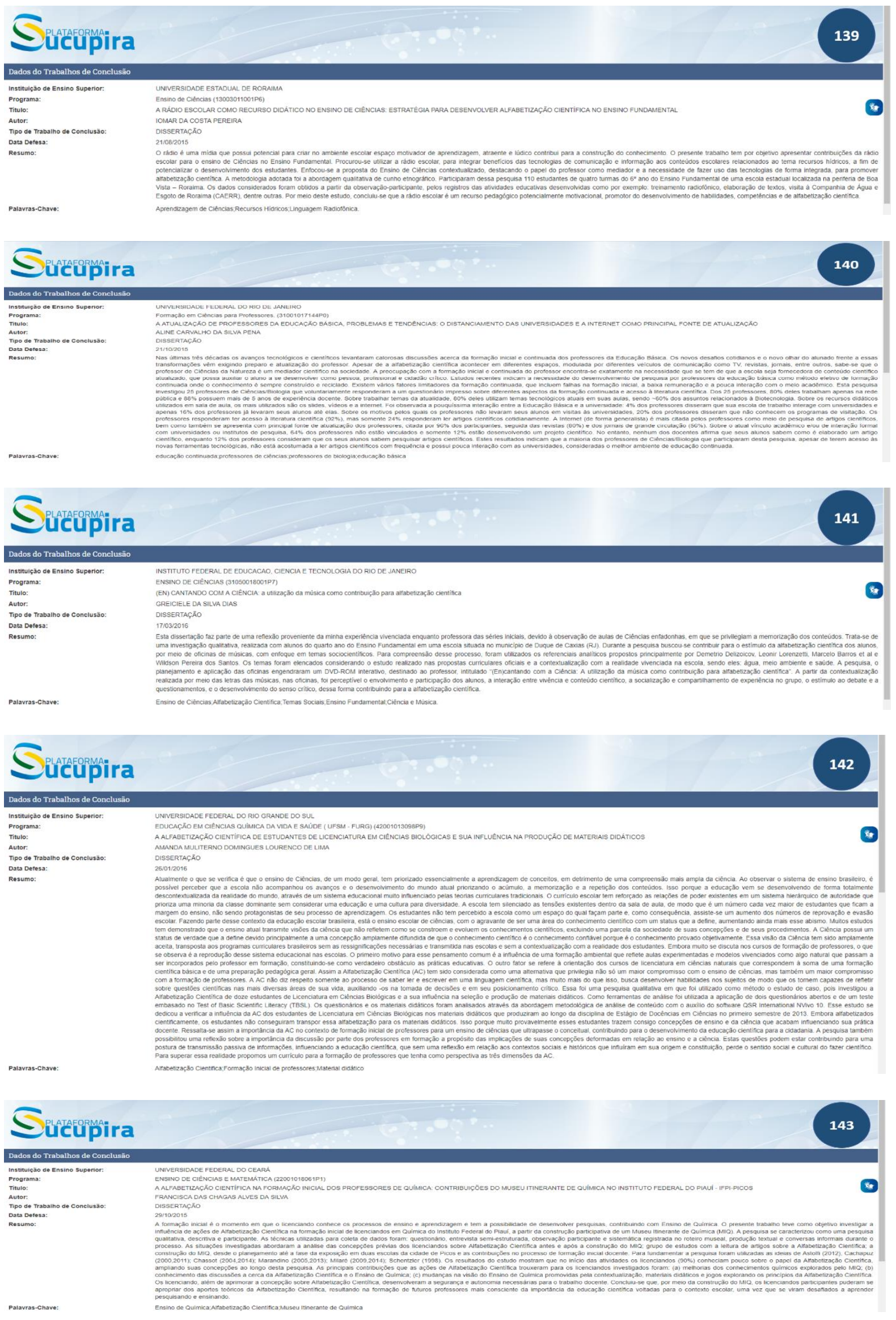

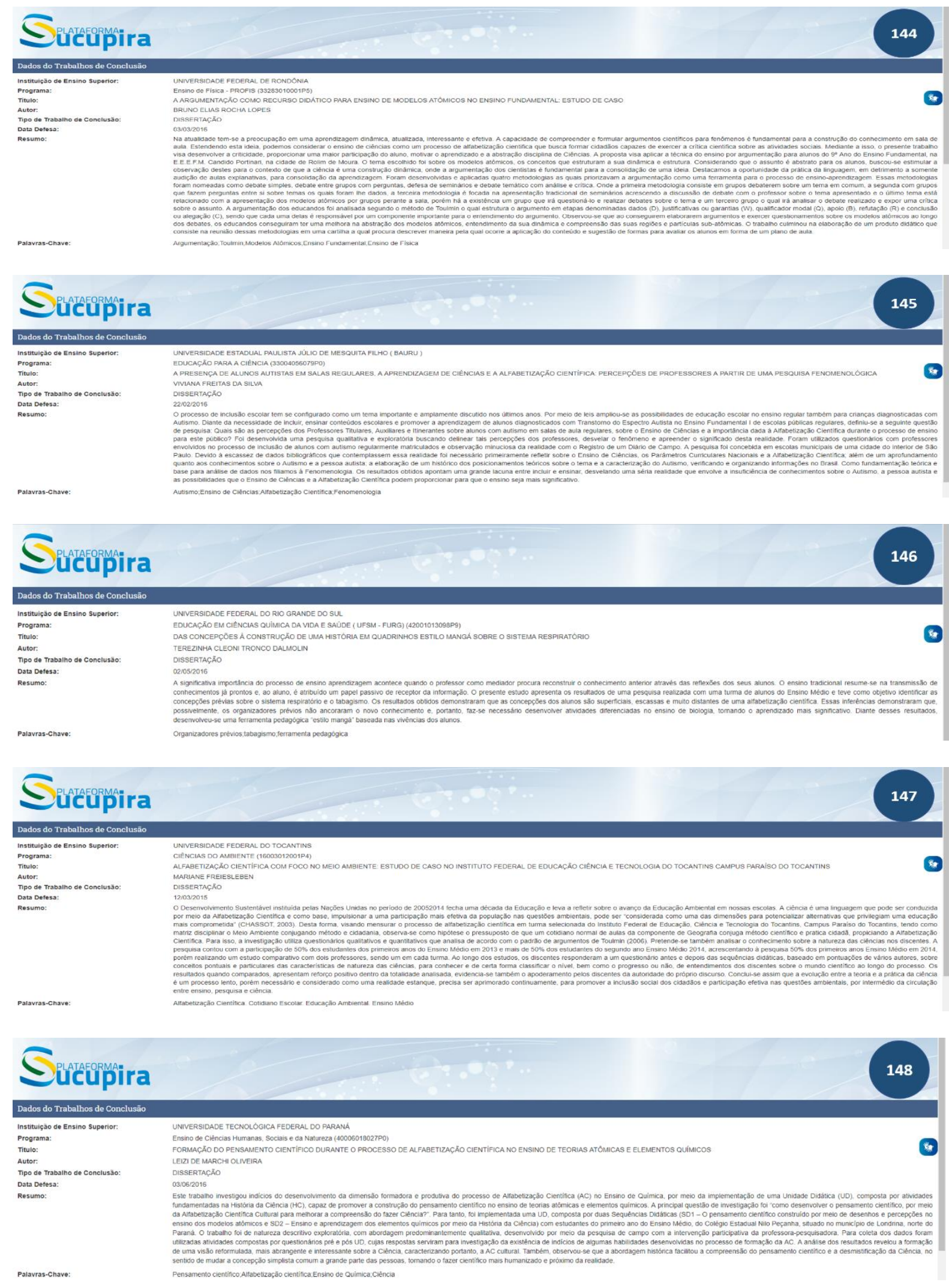

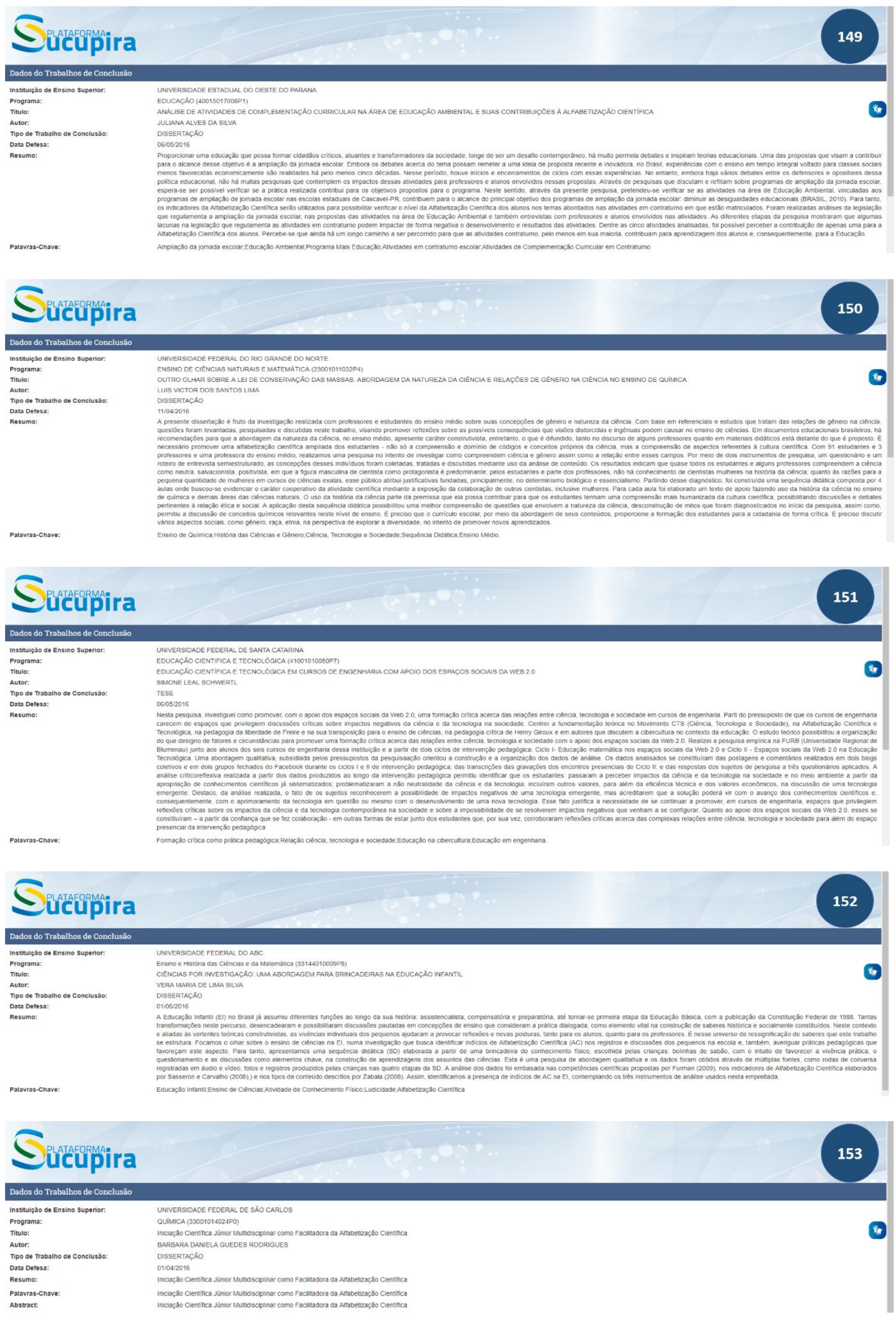

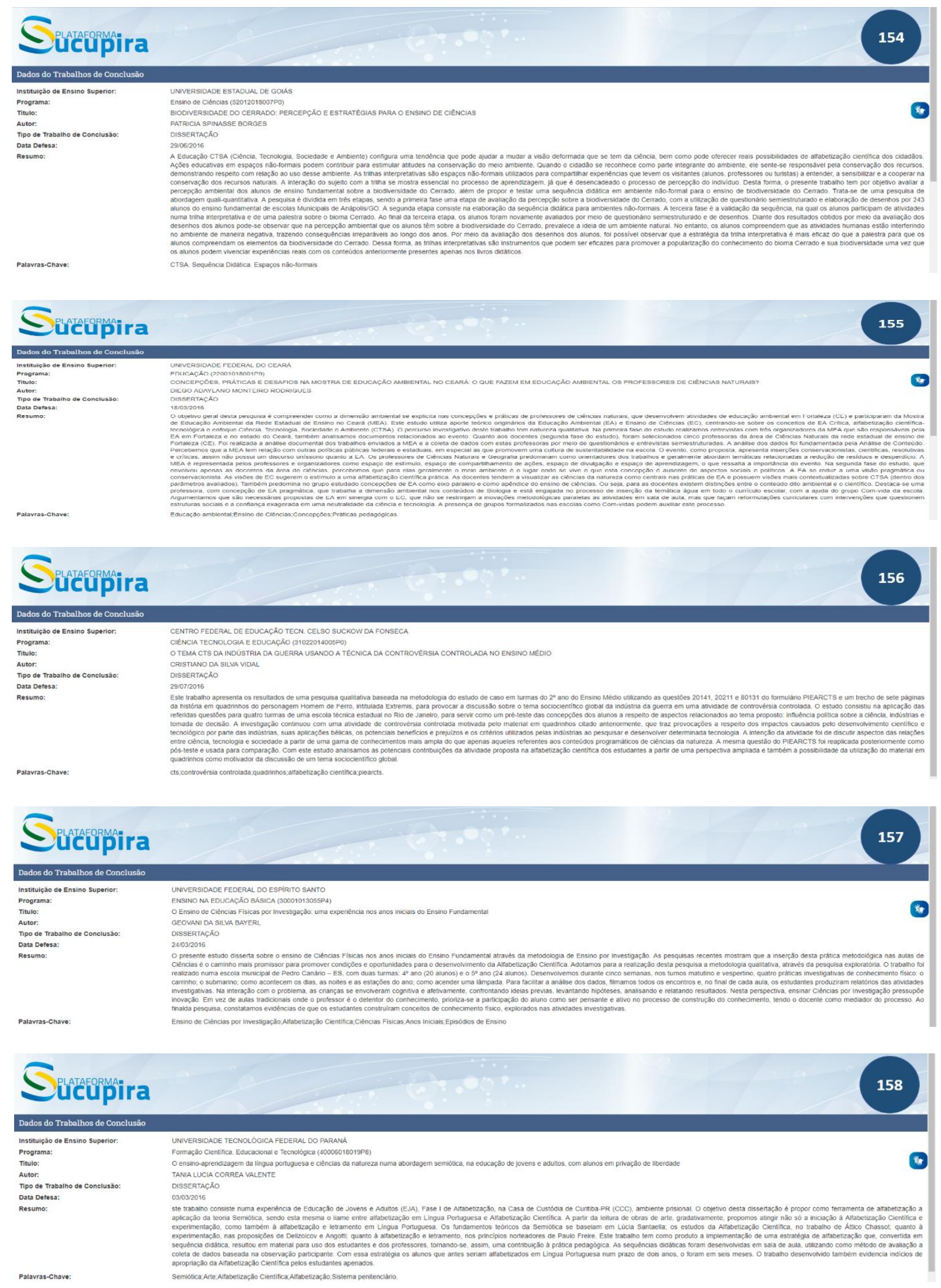

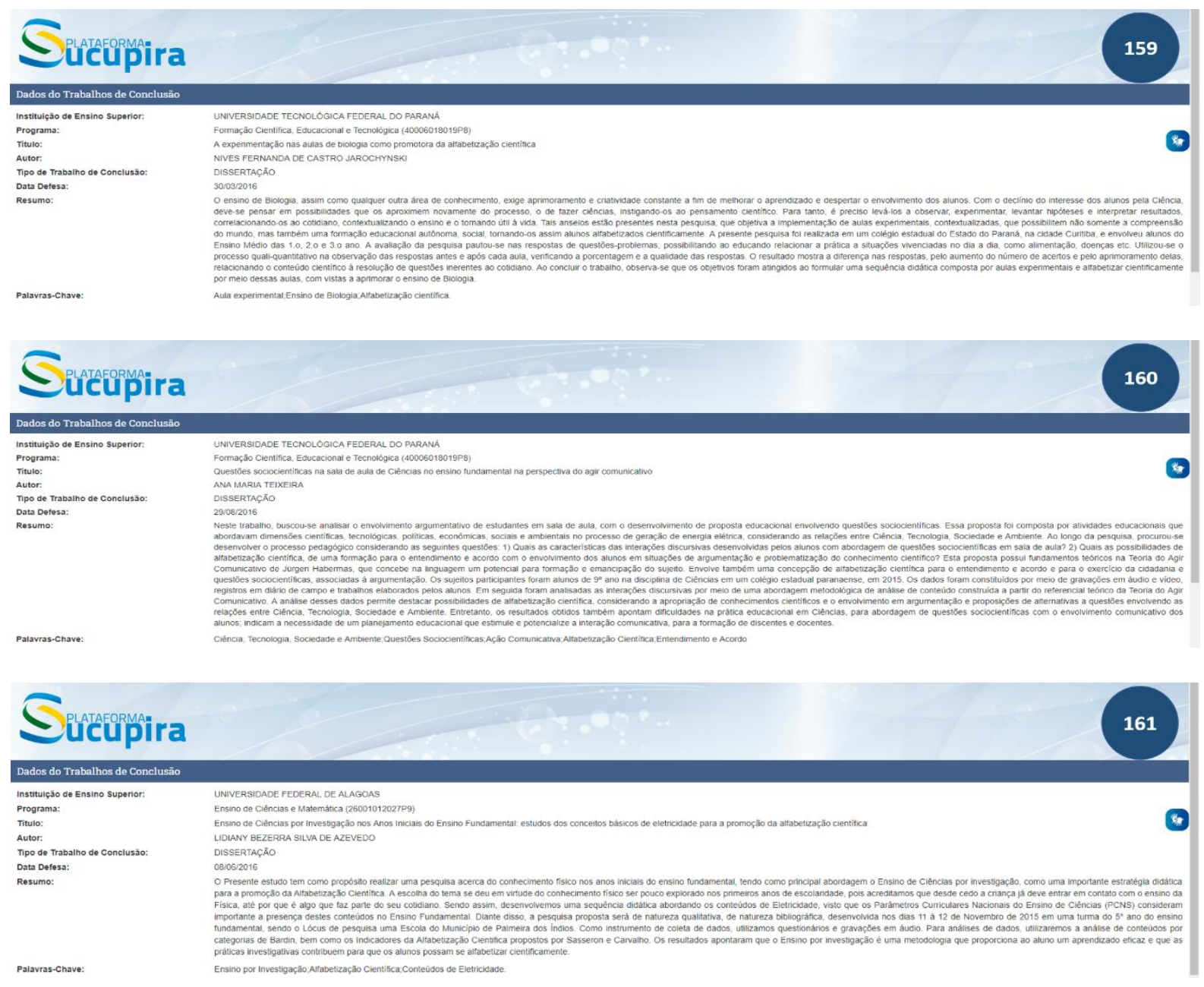

\section{Sucupira}

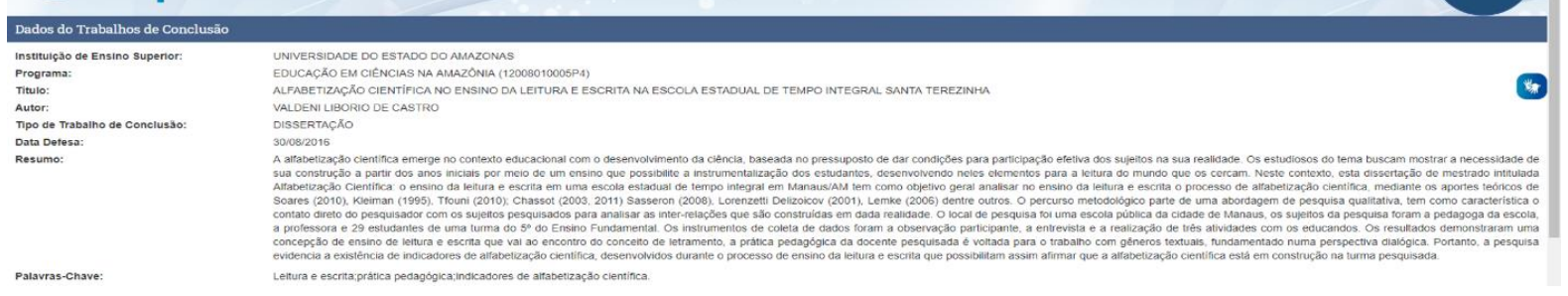

\section{Sứcupira



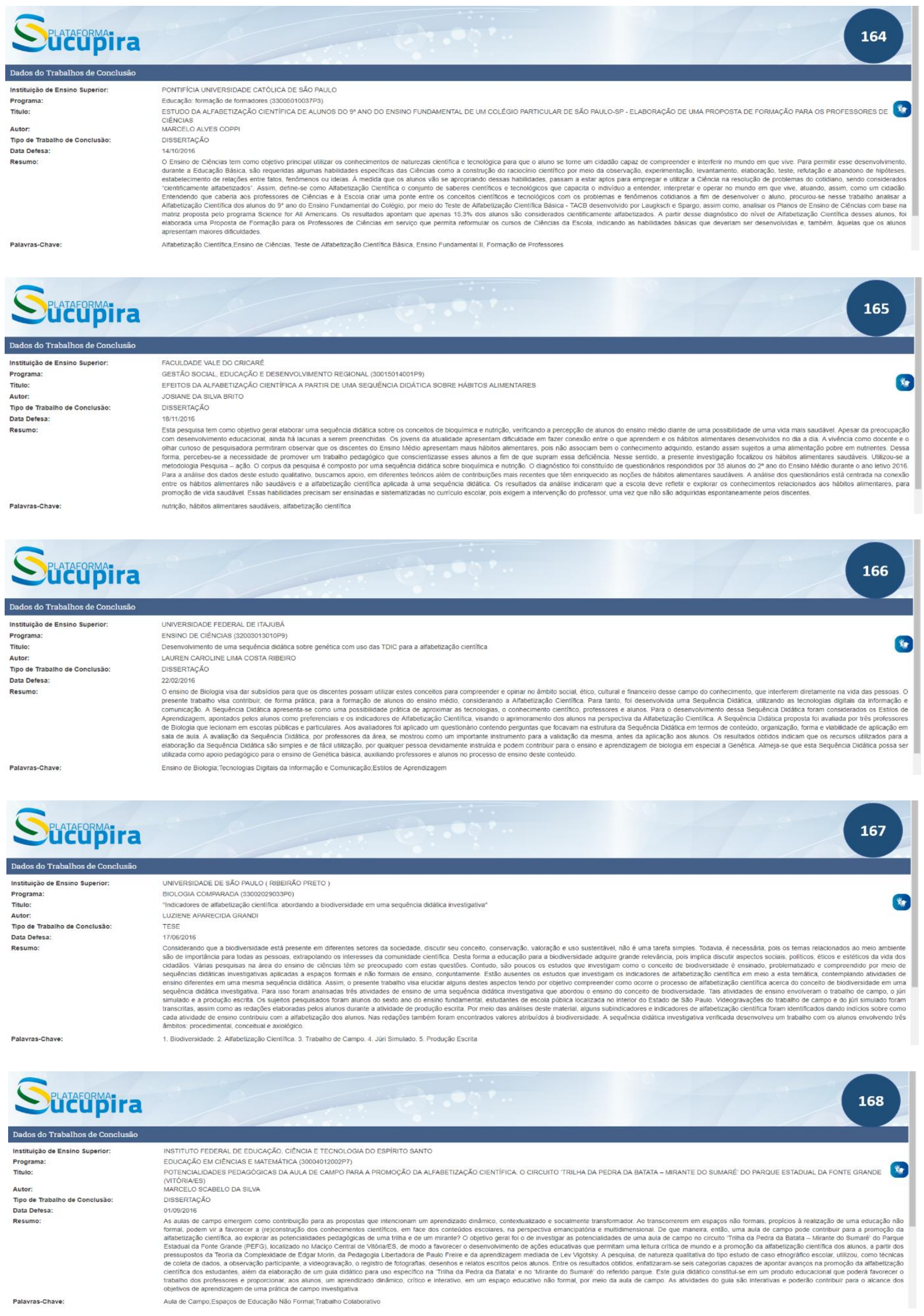

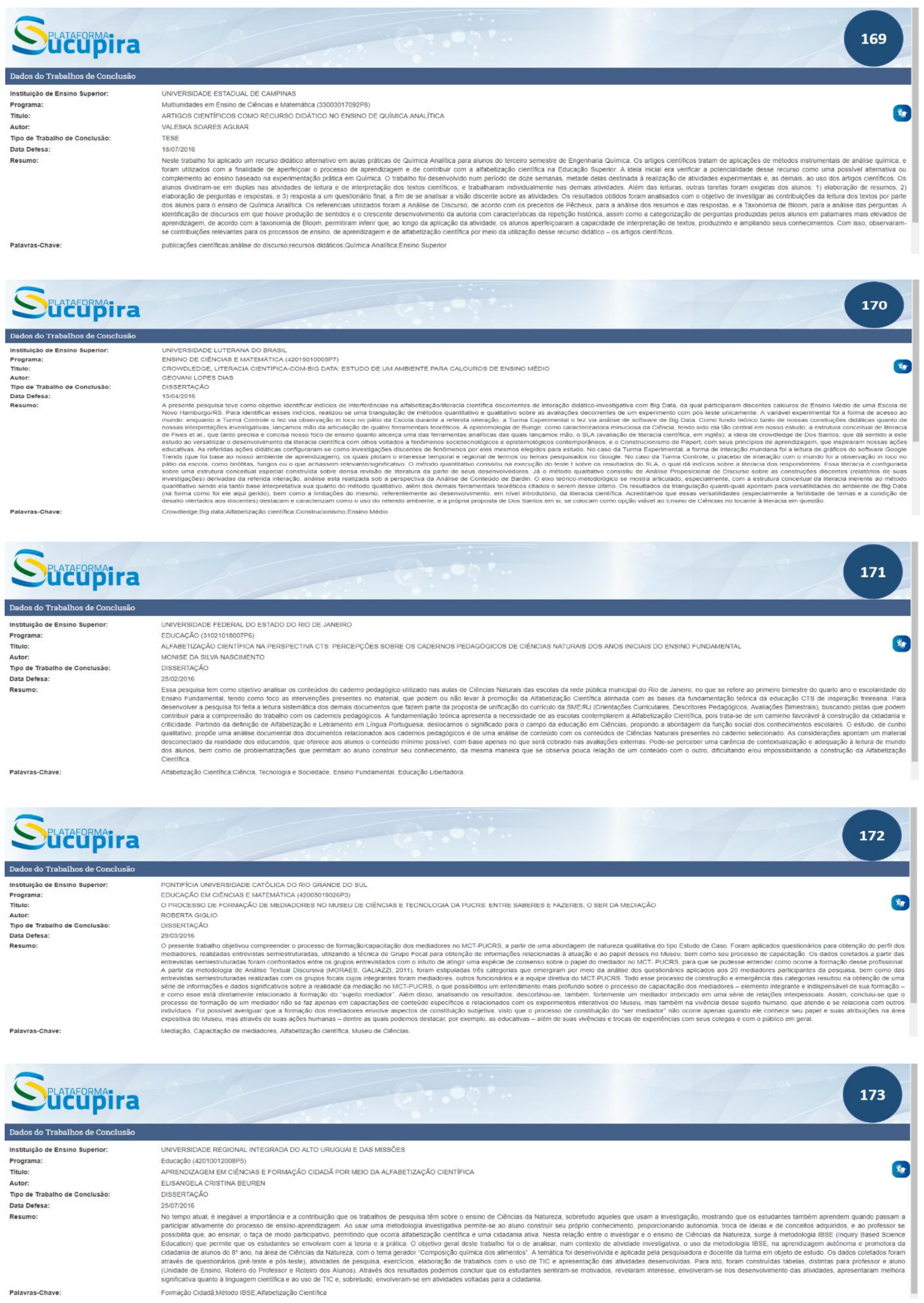

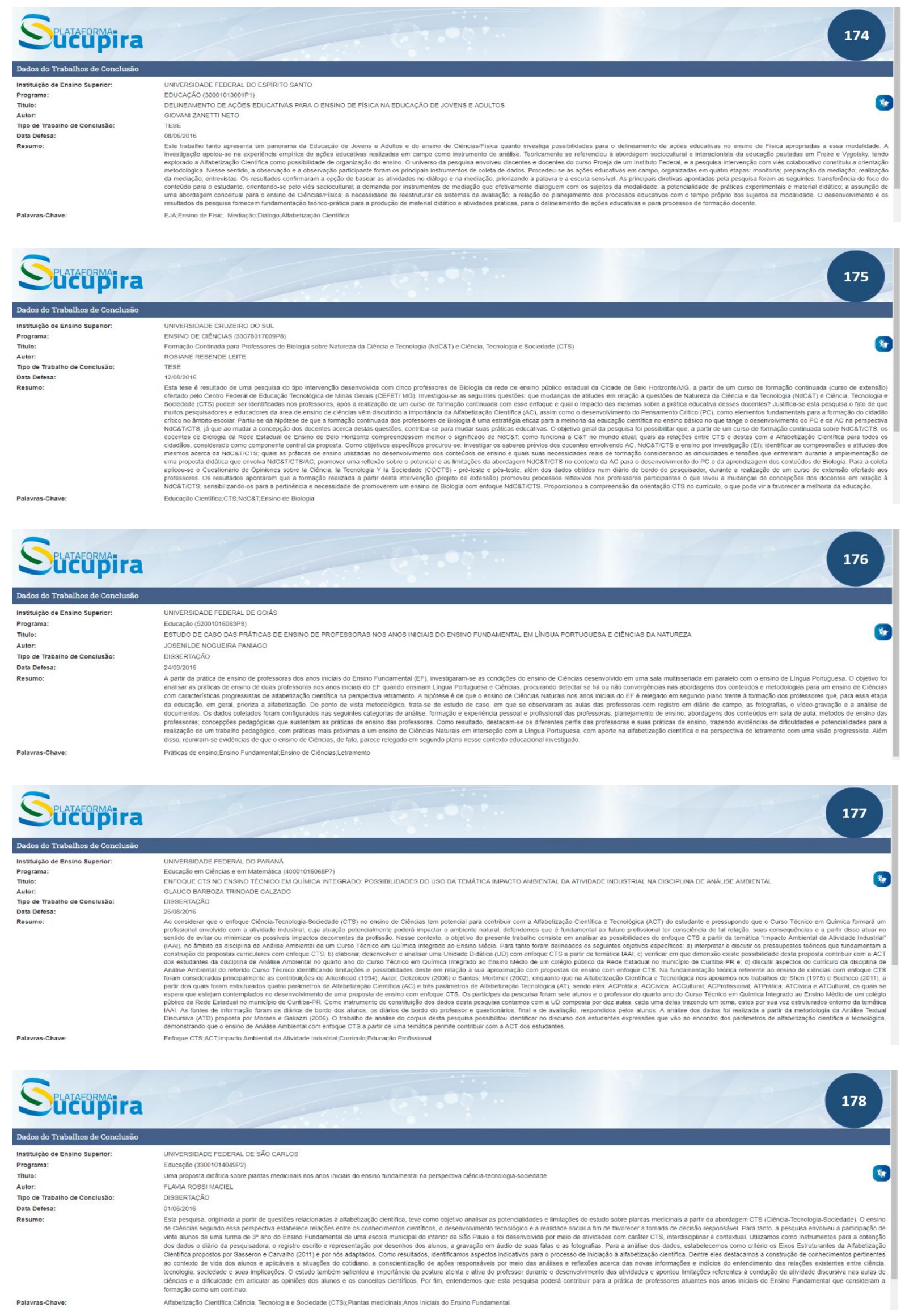

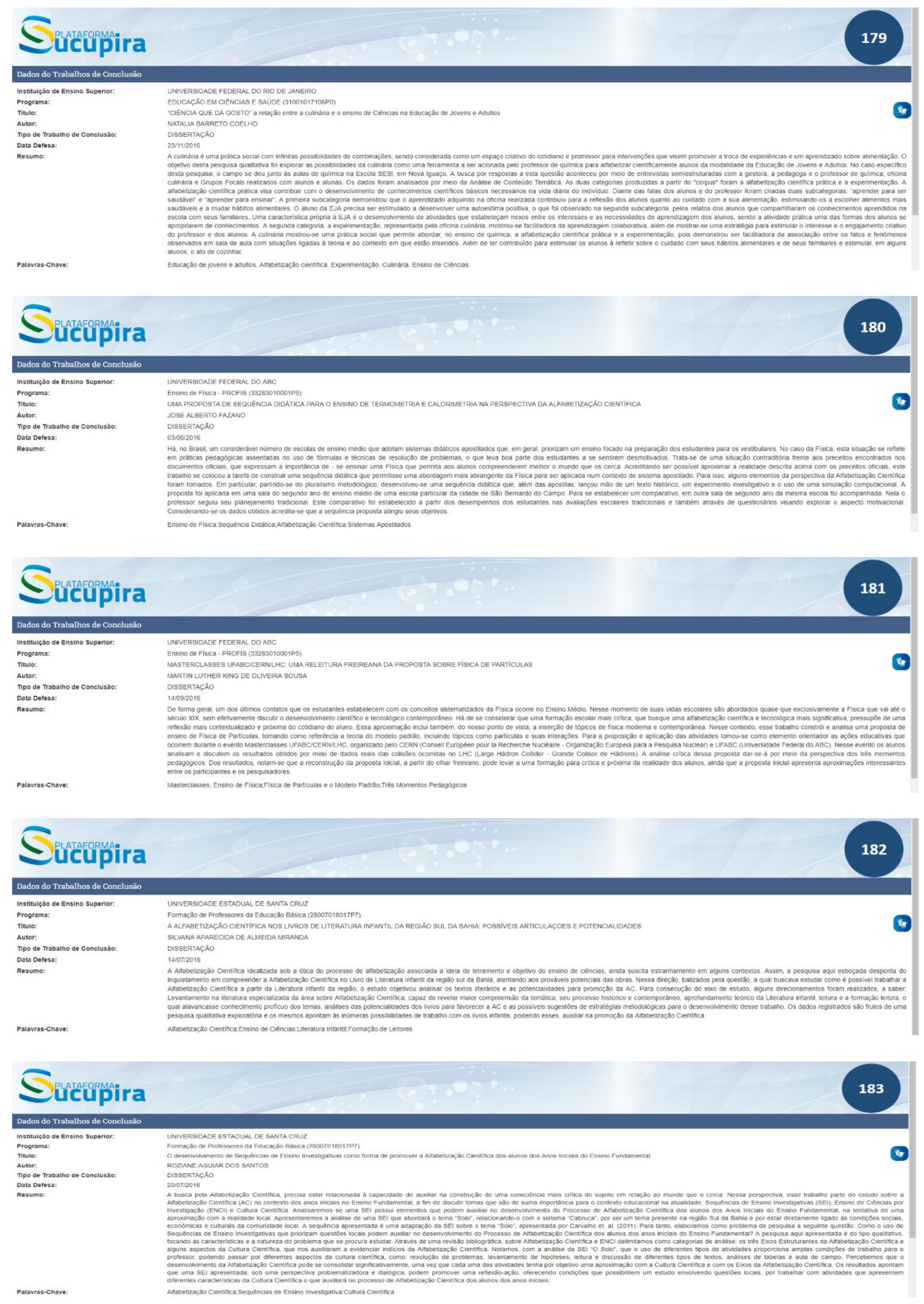

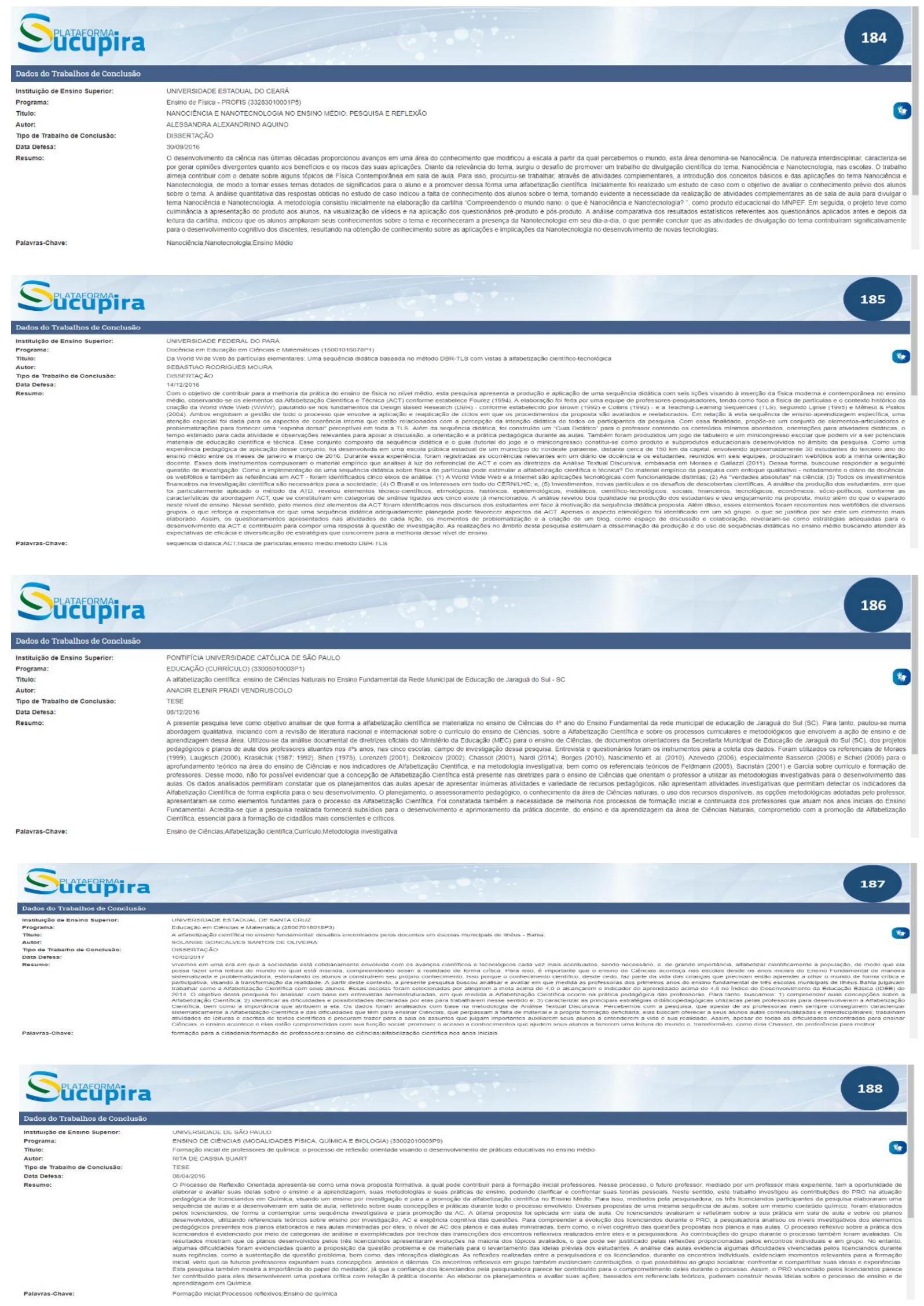


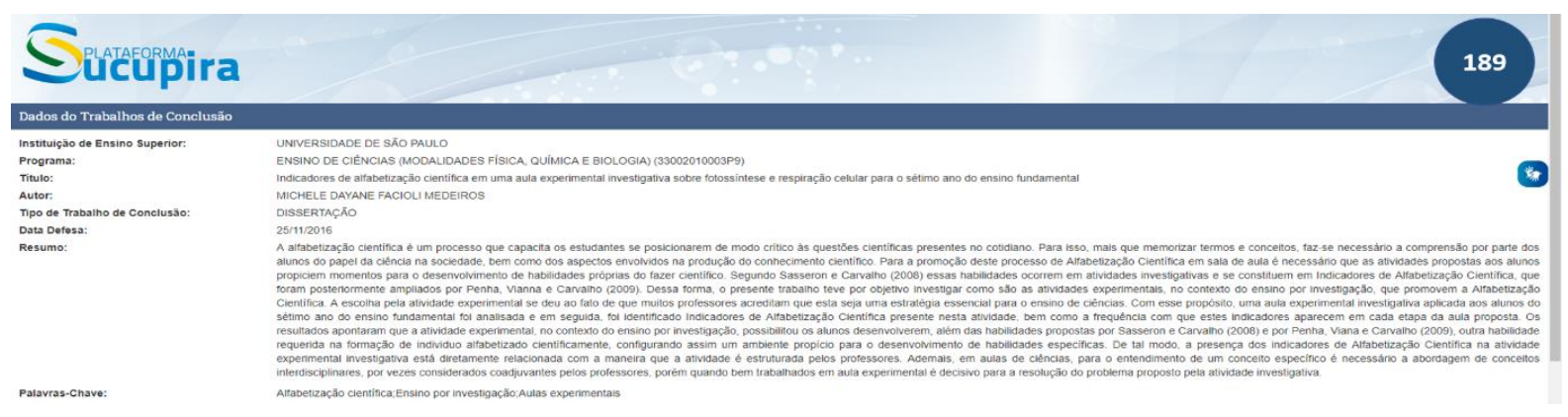

\section{Eurcupipira}

\section{Dados do Trabalhos de Conclusăo}

Instrtulicato de Ensino Superior.

Programa:
Titulo:

Autor:

Tipo de Trabaino de conclusa:

Data Dete:
Resumo:

\section{UNIVERSIDADE DE SÄO PAULO}

ENINO DE CLENCAS (MODALDADES FISICA QUIMIICAE BHOLOGIA) (33002010003P9)

TERESA DA SILVA NUNES

DISSERTAGĀ́

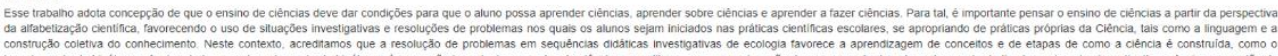

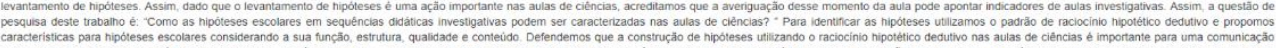

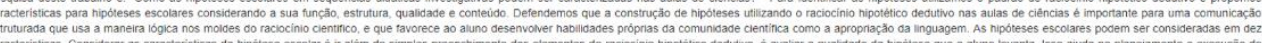

\section{Sucupira}

\section{Dados do Trabalhos de Conclusăo}

Instrtulę̧o de Ensino superior:

Programa:

UNIVERSIDADE FEDERAL DO ABC

UNIVERSIDADE FEDERAL DO ABC

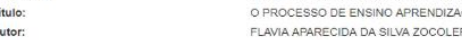

OISCURSO CIENTFIICO NOS PRMMEROS ANOS DO ENSINO FUNDAMENTAL

DISSERTAGĀC

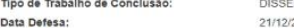

Resumo:
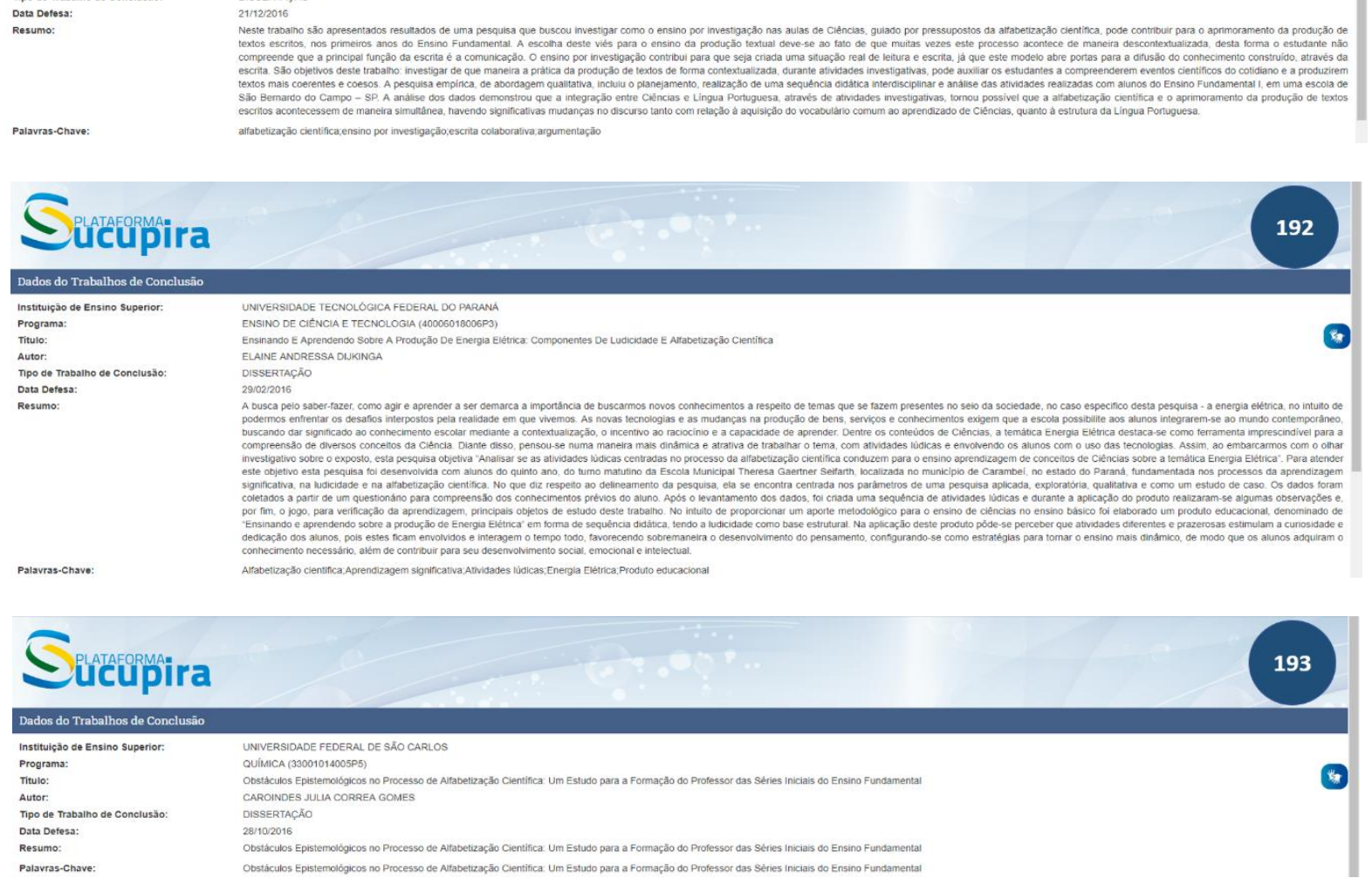

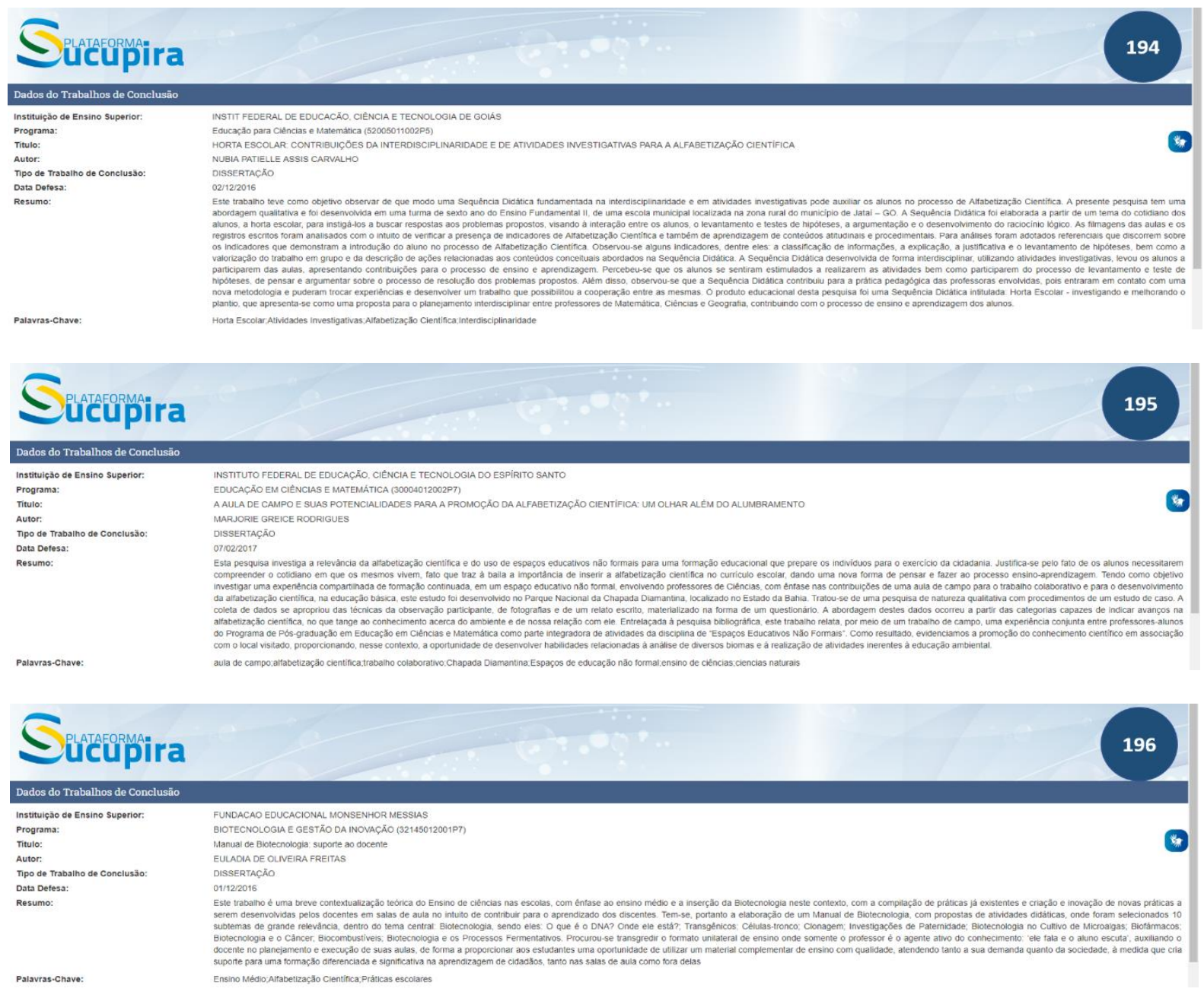

\section{Sucupira}

\section{Dados do Trabalhos de Conclusão}

Instrtuiçăo de Ensino Superior

Proorame

Tituto

Anpo de Trabastho de conclusas

Data Detess:

UNIVERSIDADE DE SÃO PAULO (RIBEIRÁO PRETO)

Educarso $133002020542 P_{0}$

MiRTAMA NAVARRO DE CASTRO NUNES

DISSERTAĞ̄o

090022016

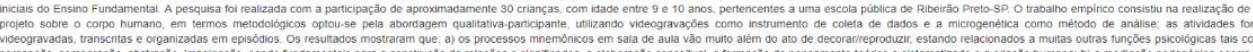

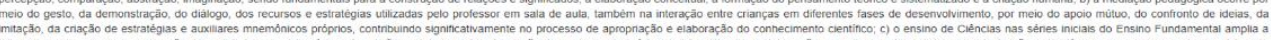

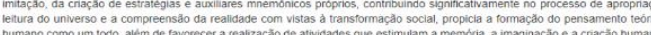

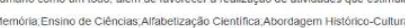

\section{Sucupira}

Instituiçăo de Ensino Superior:

Programa:

INSTTUTO FEDERA DE EDUCACĞO CIENCIA E TECNOLOGIA DE SÁO PAULO

Titulo:

Mpo de Trabalino de concluss o

Data Detesa:
Resumo:

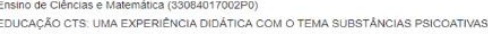

THAIS DE CASSIA OLIVEIRA

DISSERTACAOAO

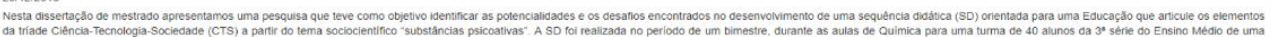

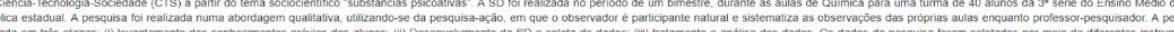

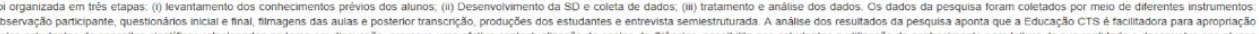

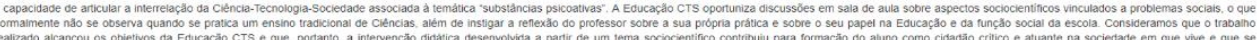




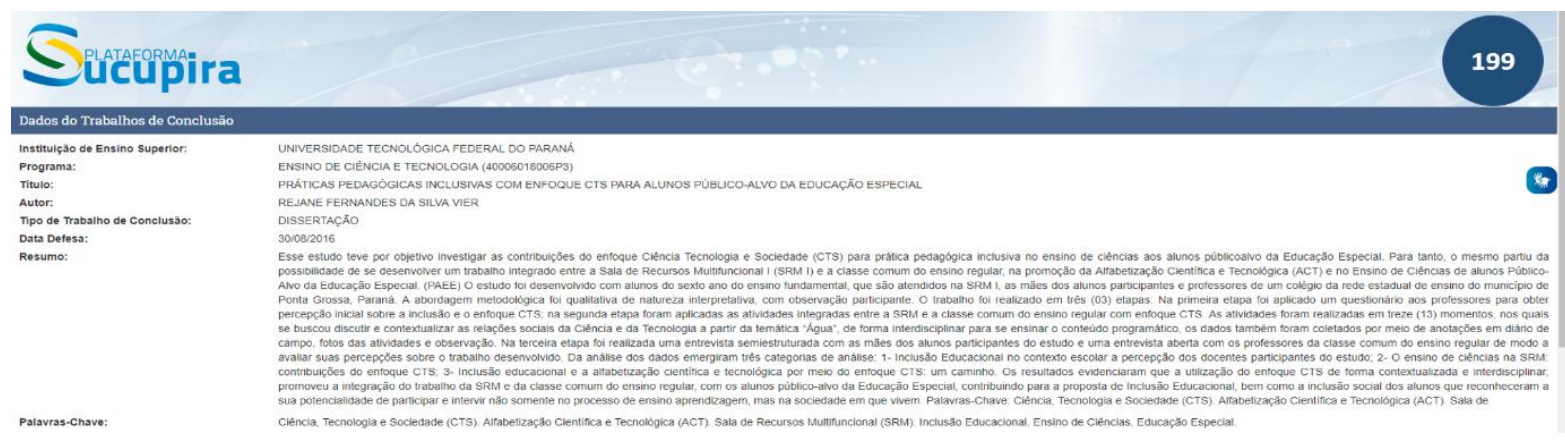

\begin{tabular}{|c|c|}
\hline \multicolumn{2}{|c|}{ Dados do Trabalhos de Conclusão } \\
\hline 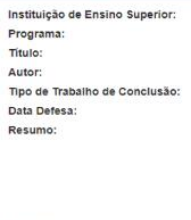 & 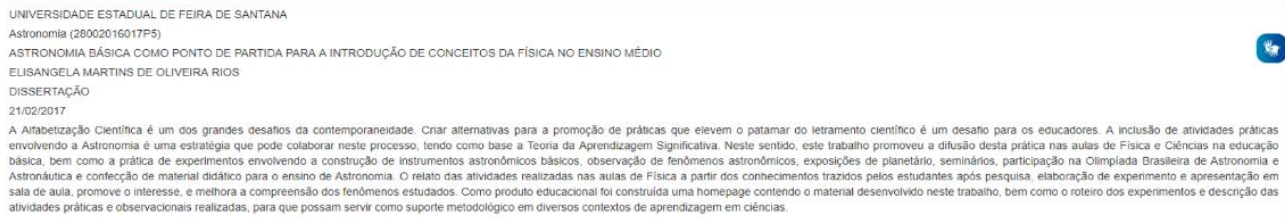 \\
\hline Palavras-chave: & 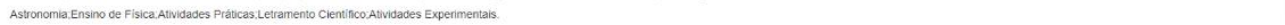 \\
\hline
\end{tabular}
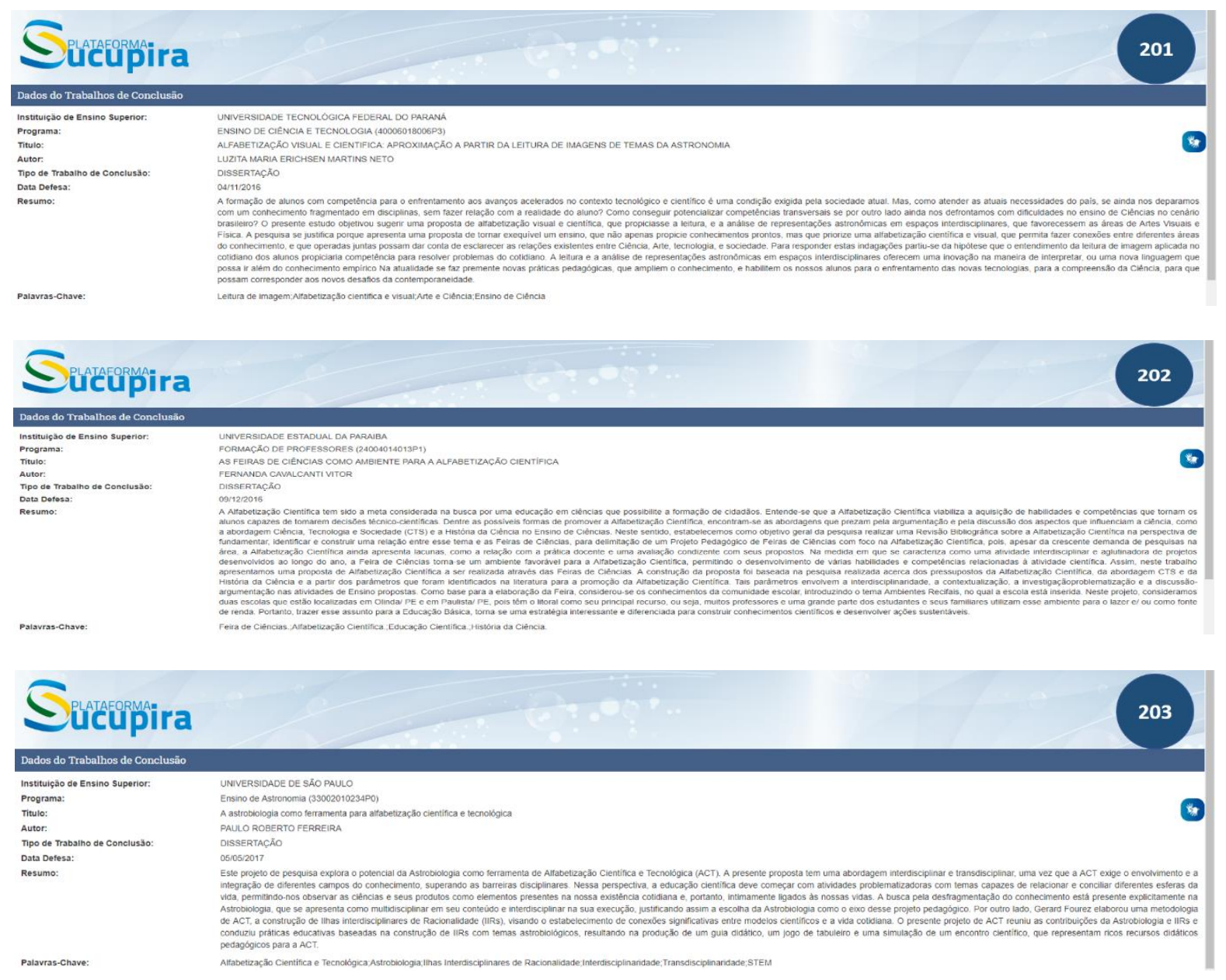

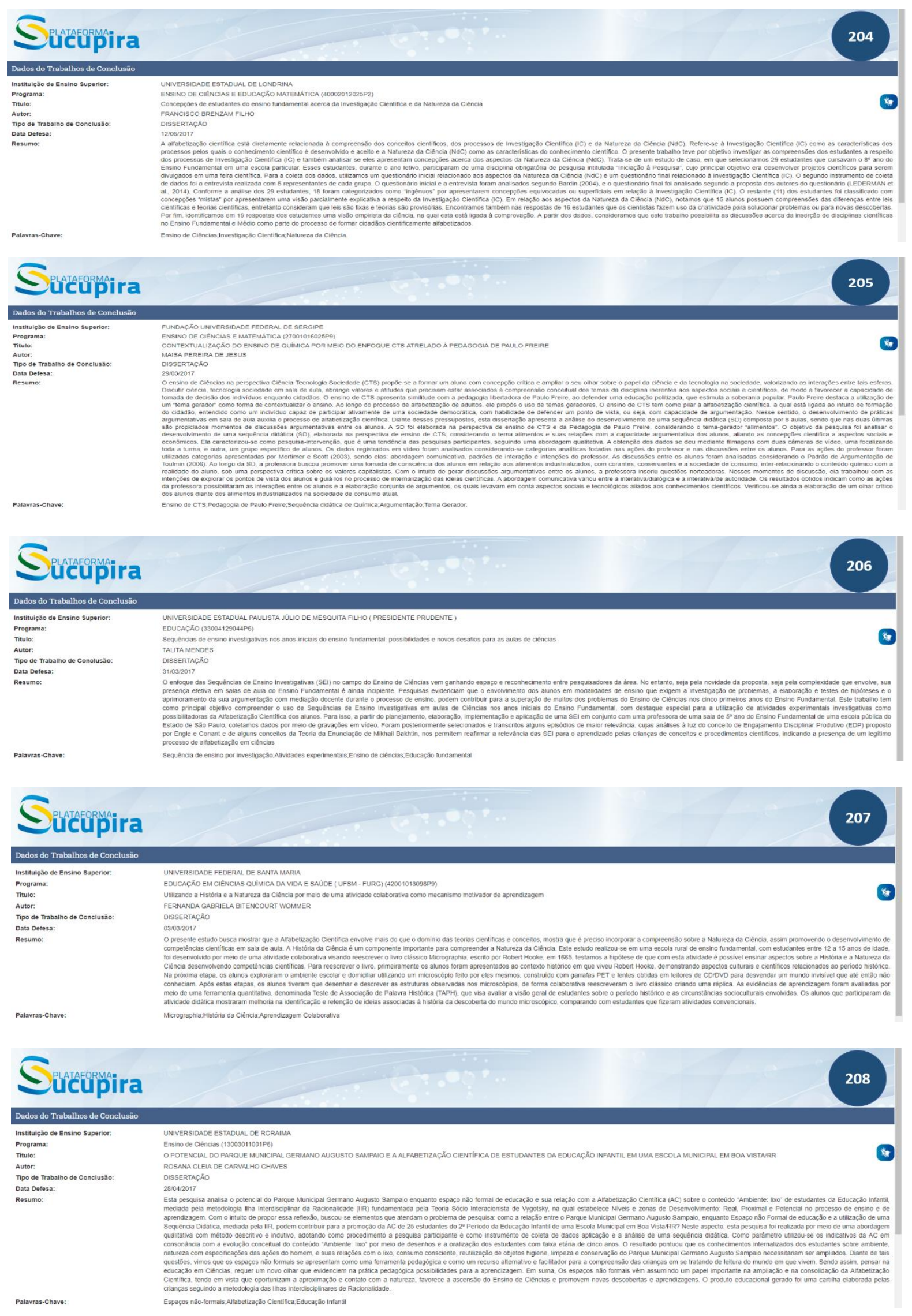

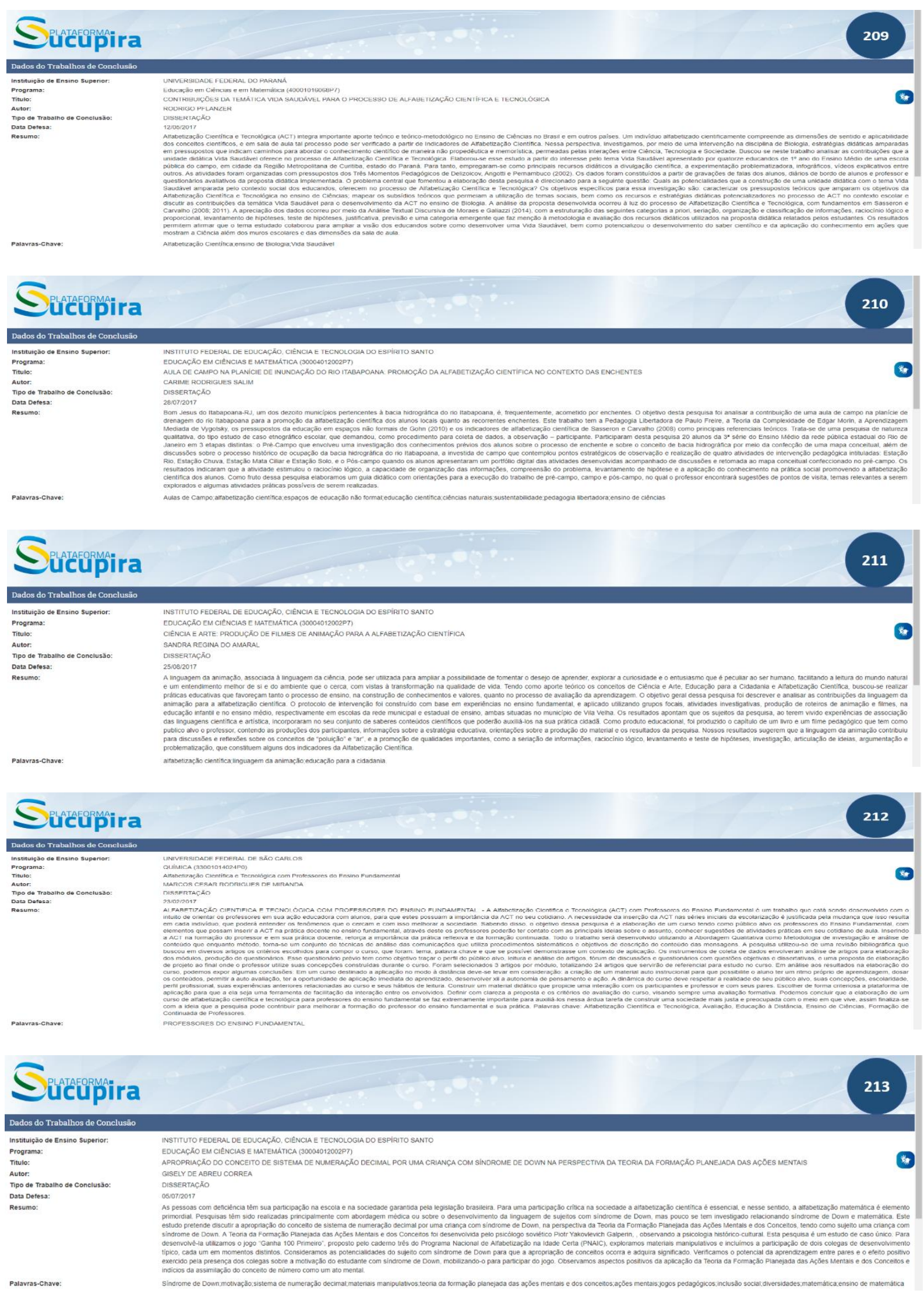

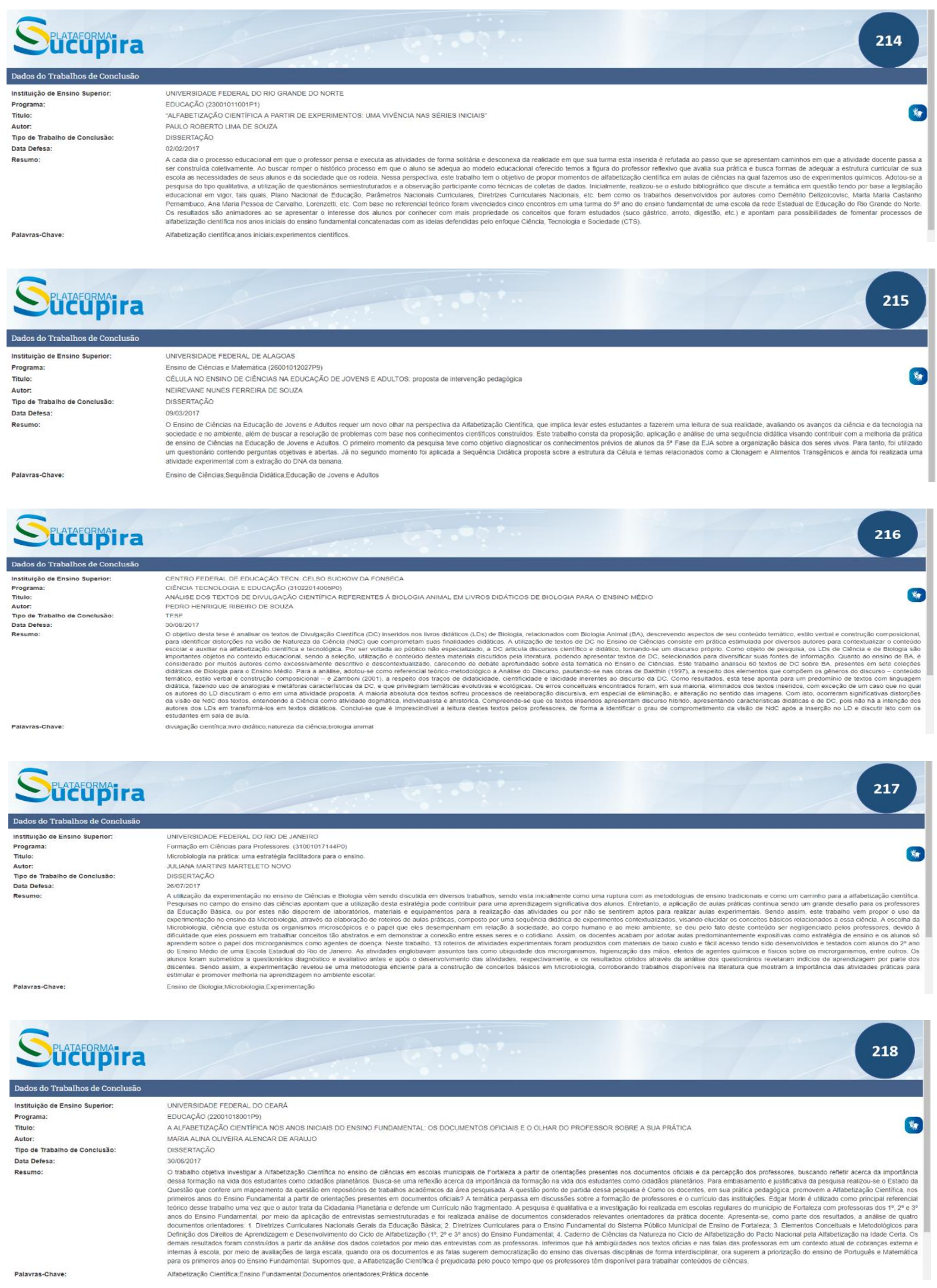

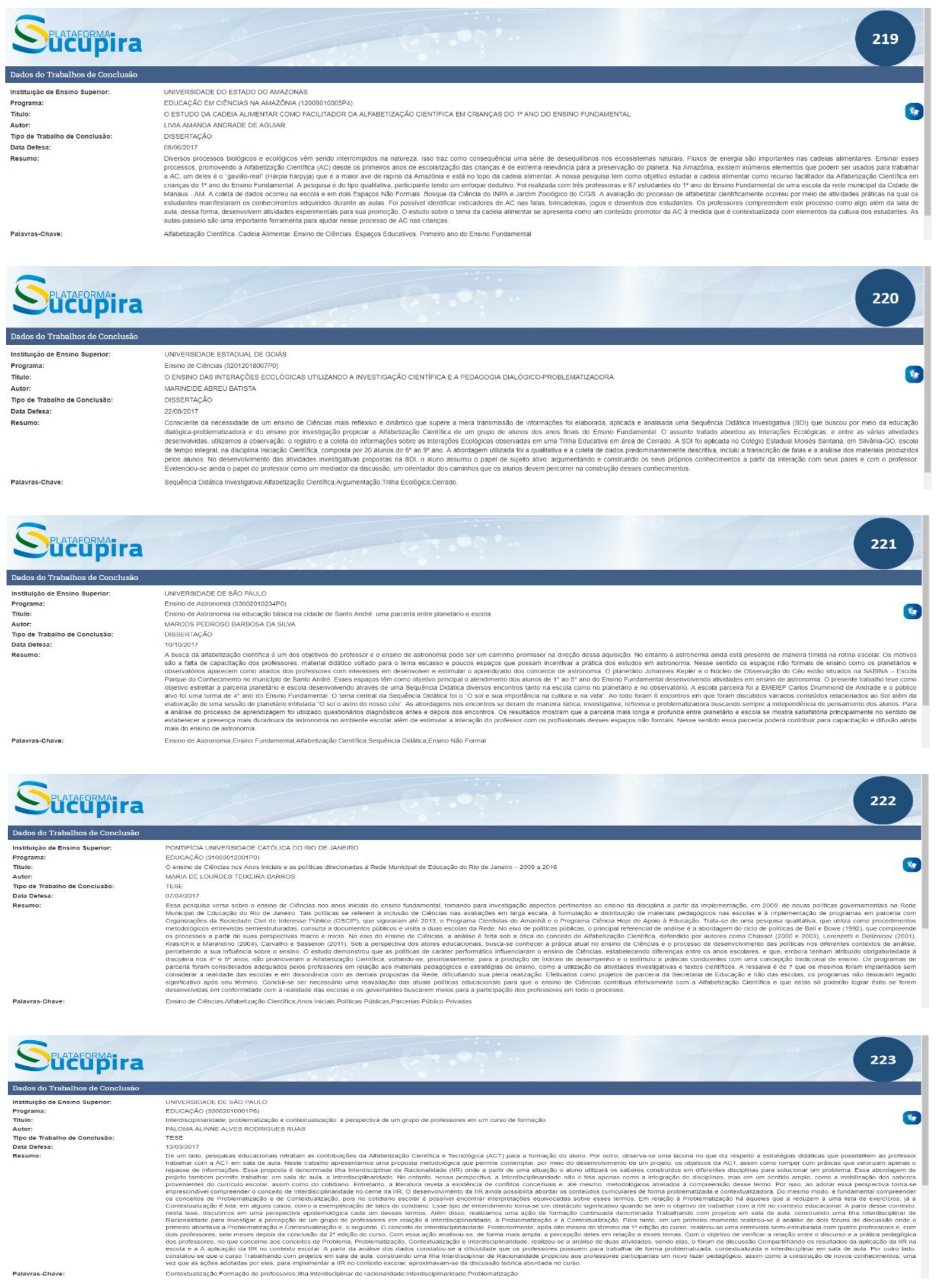

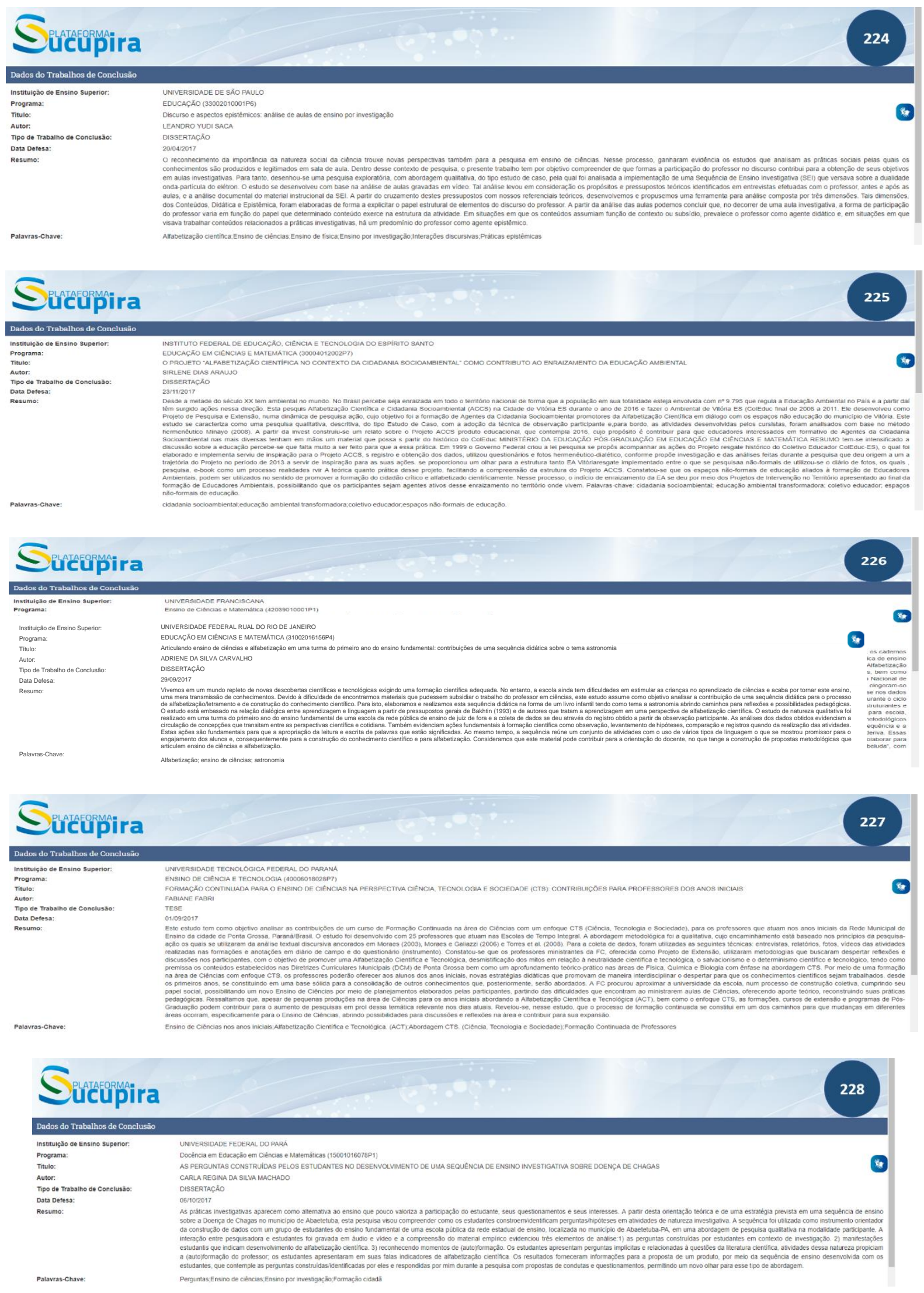

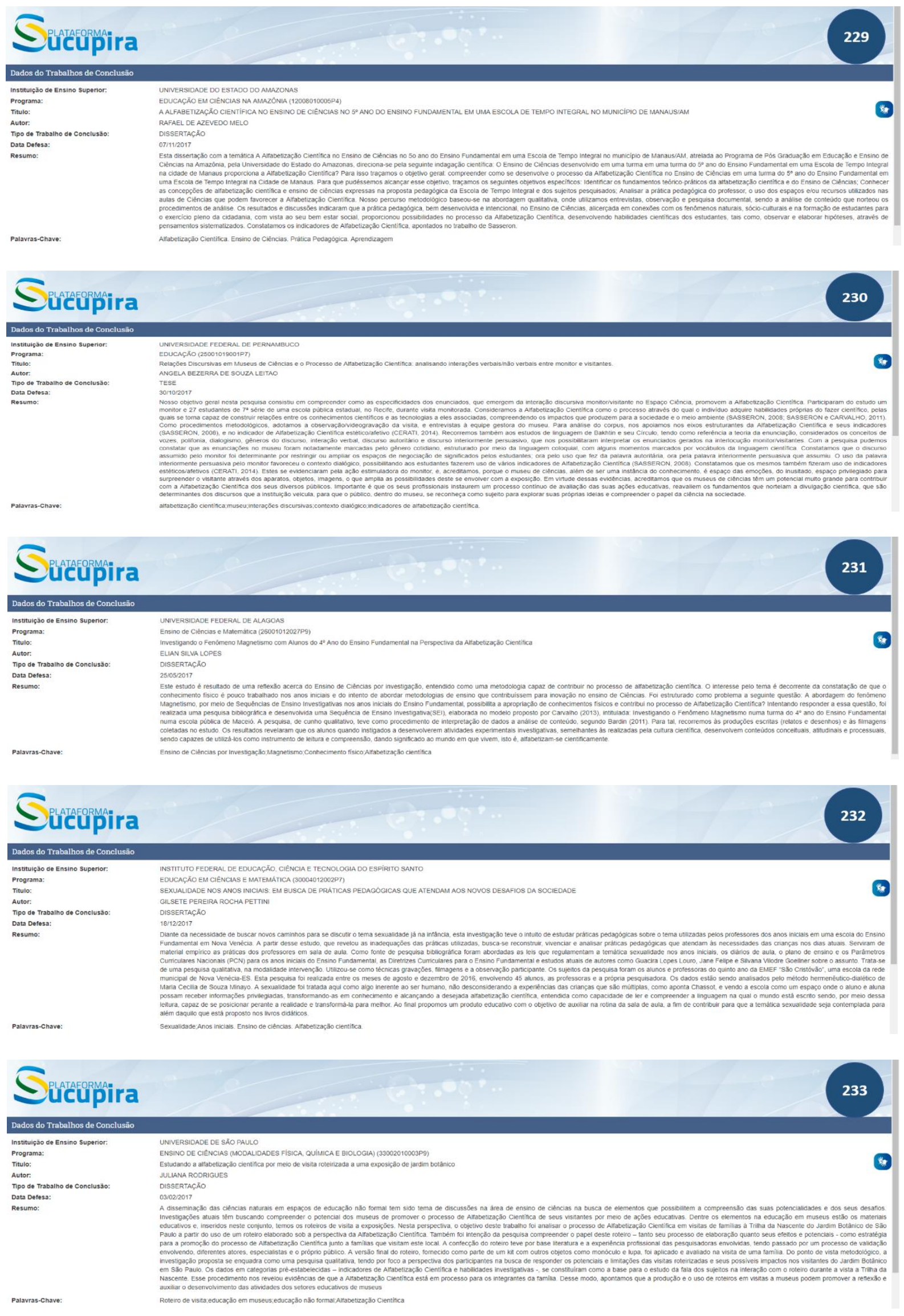

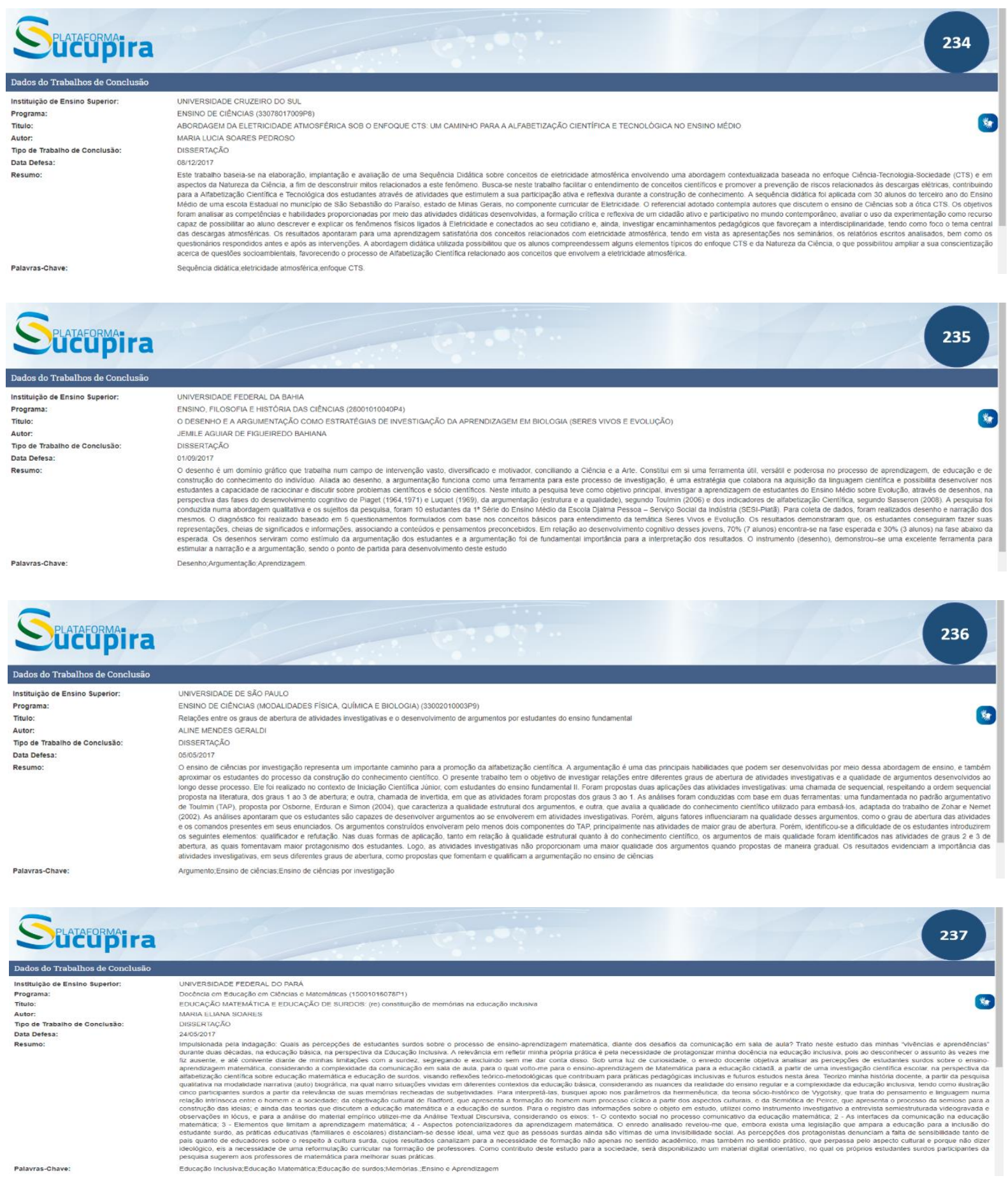

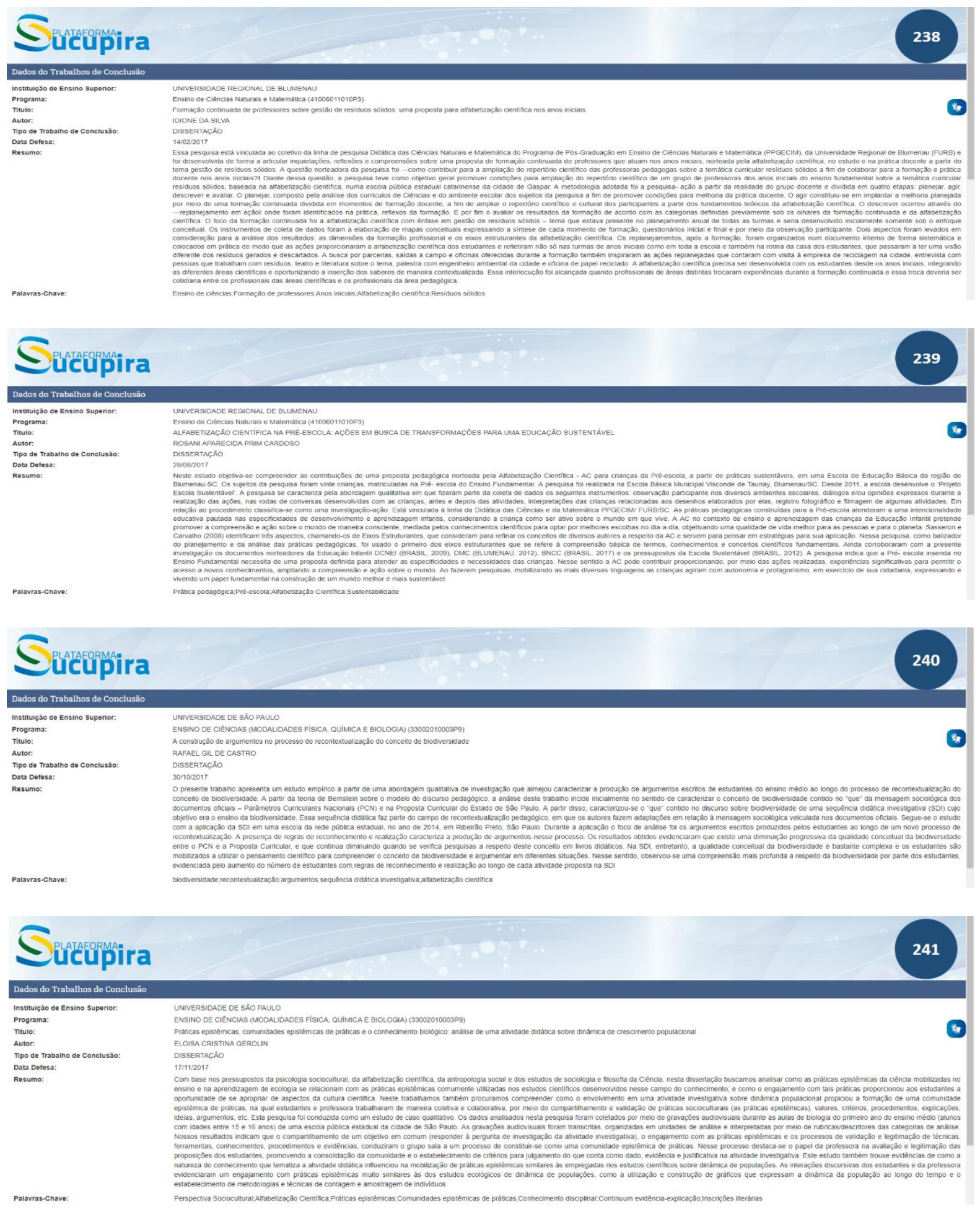

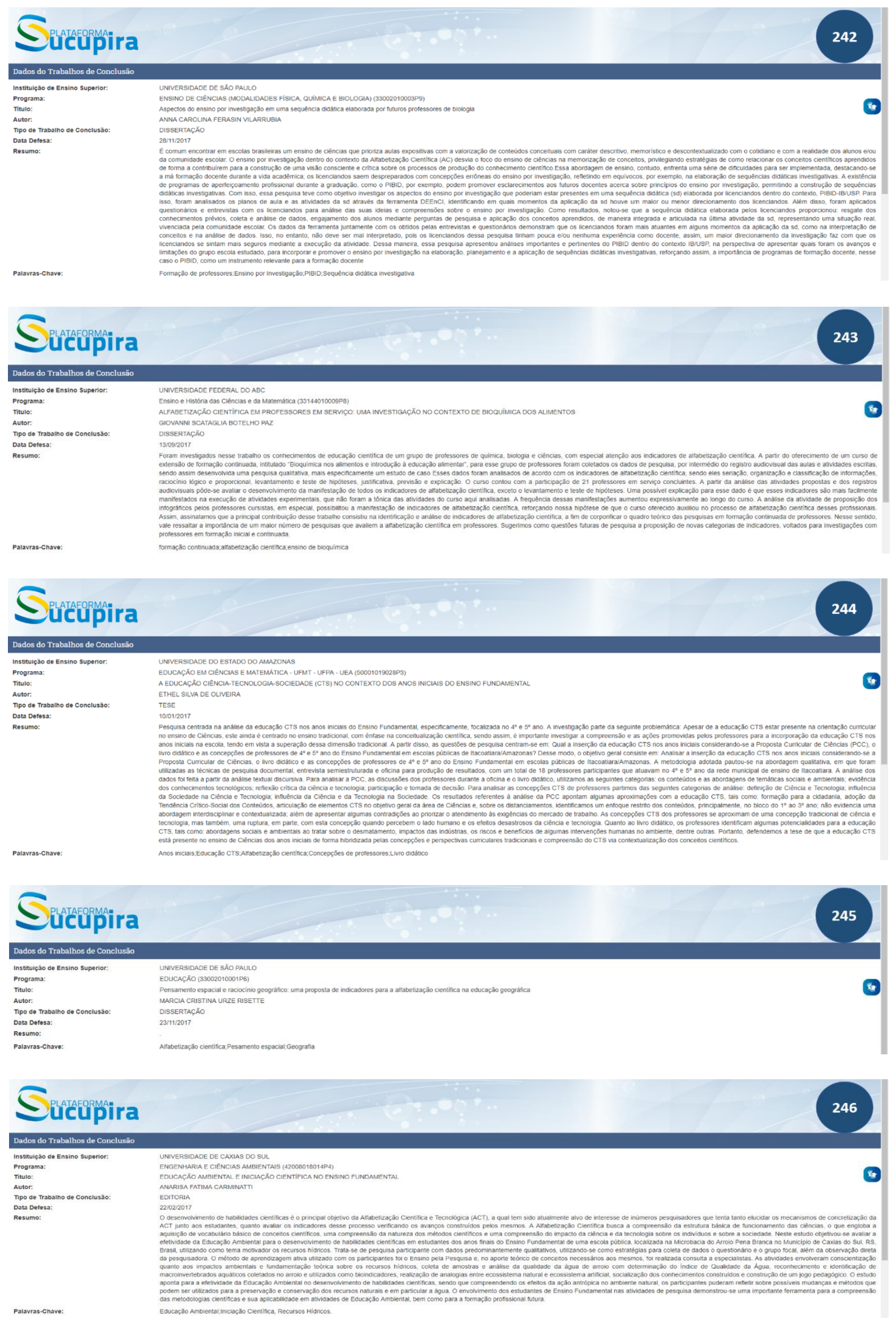


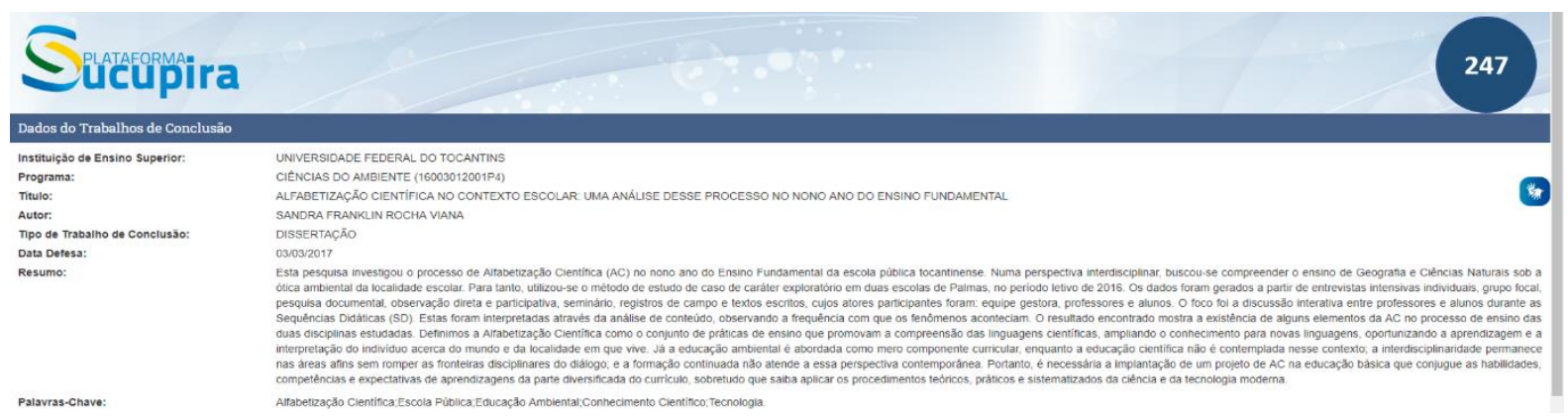

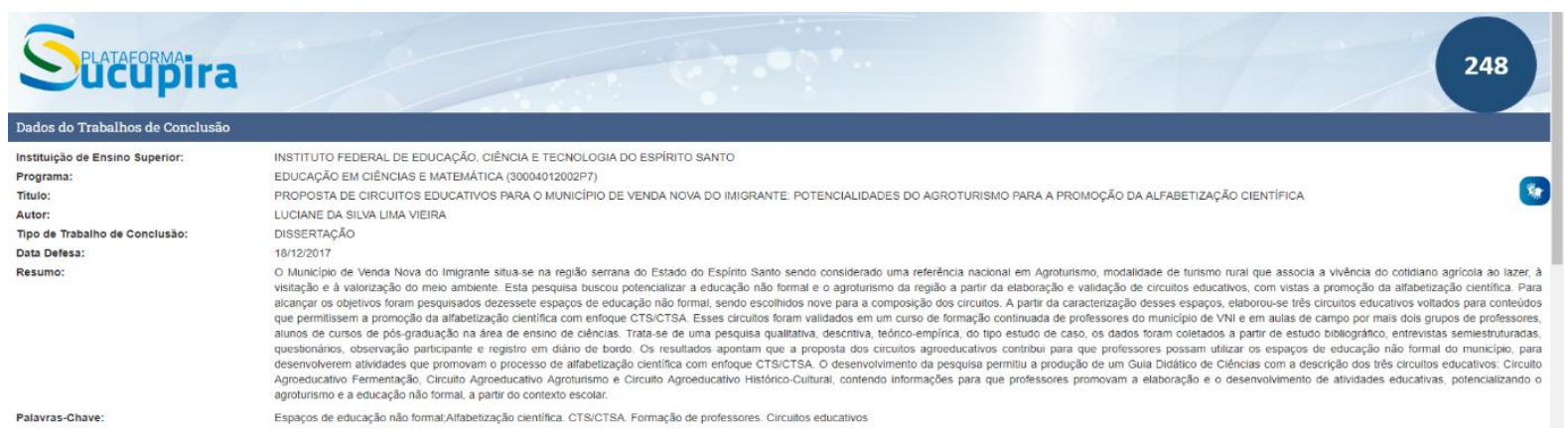
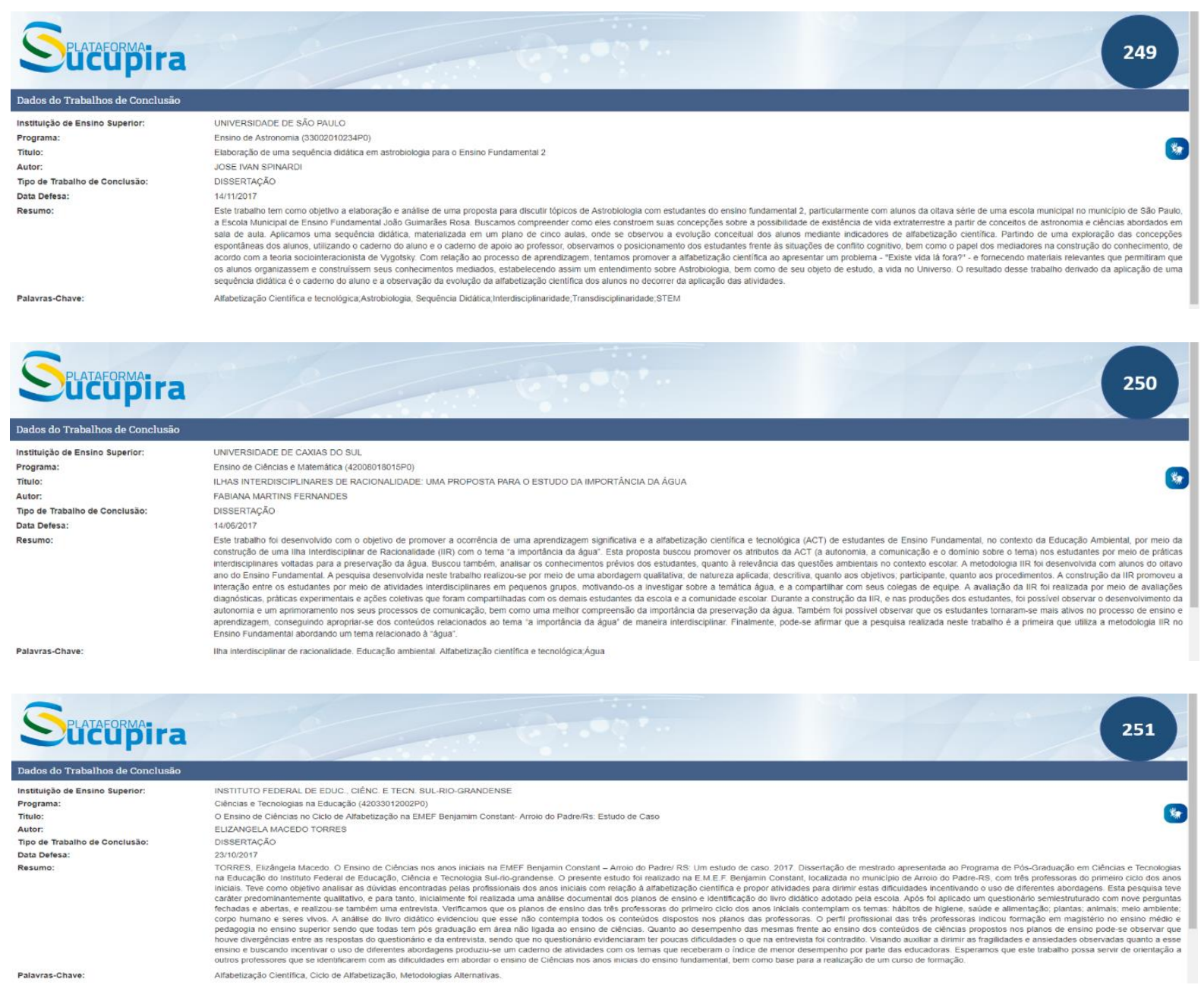

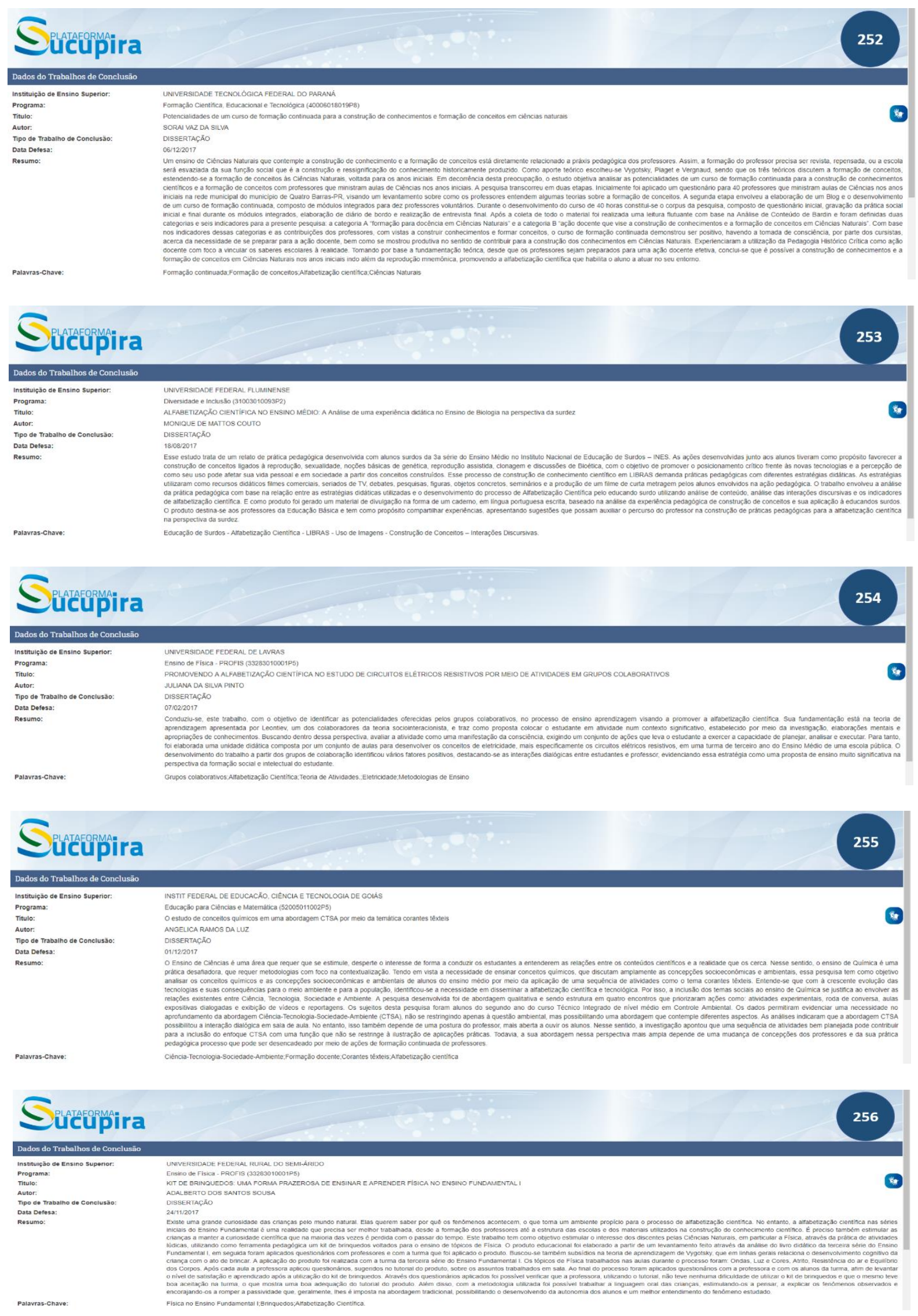

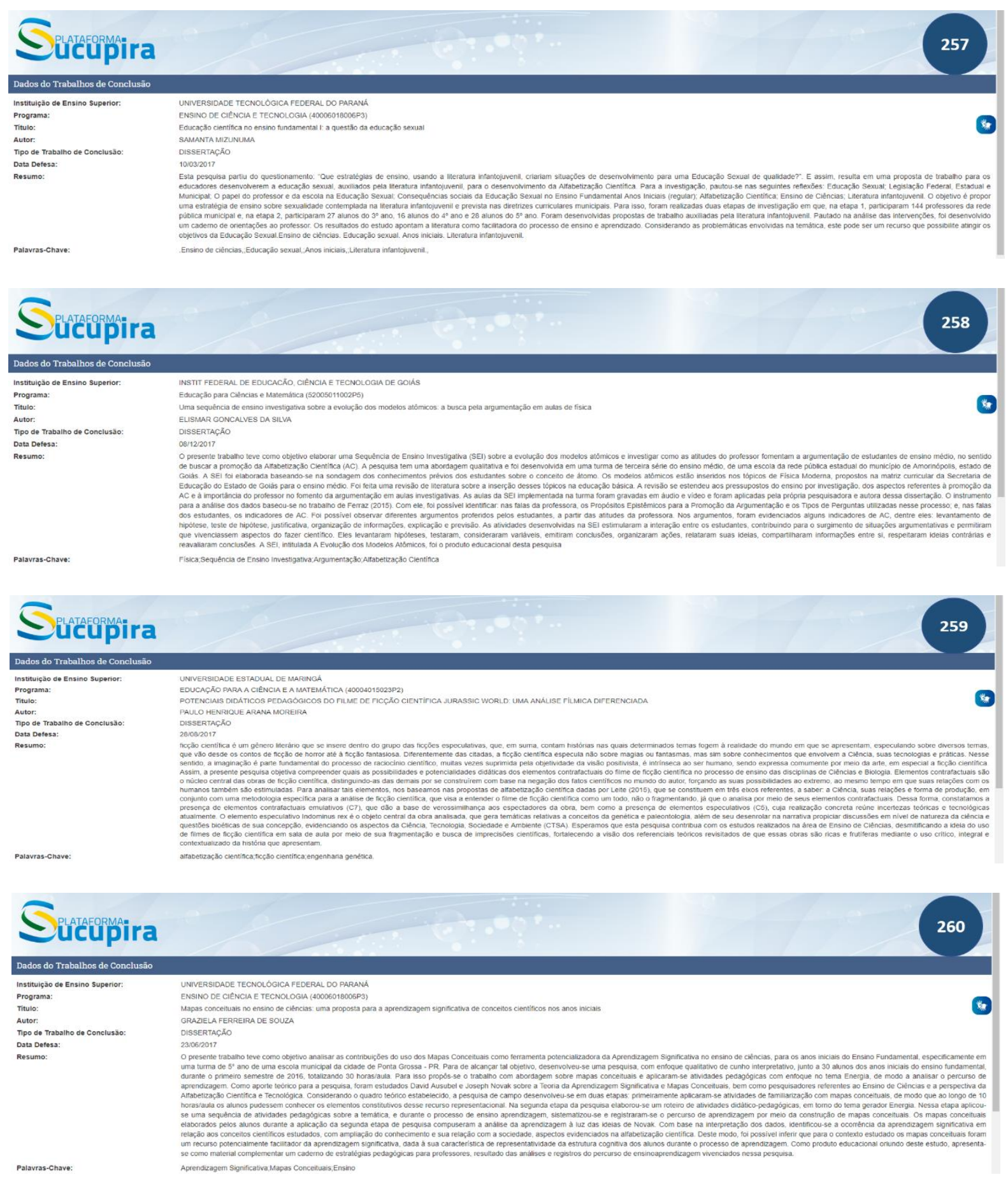


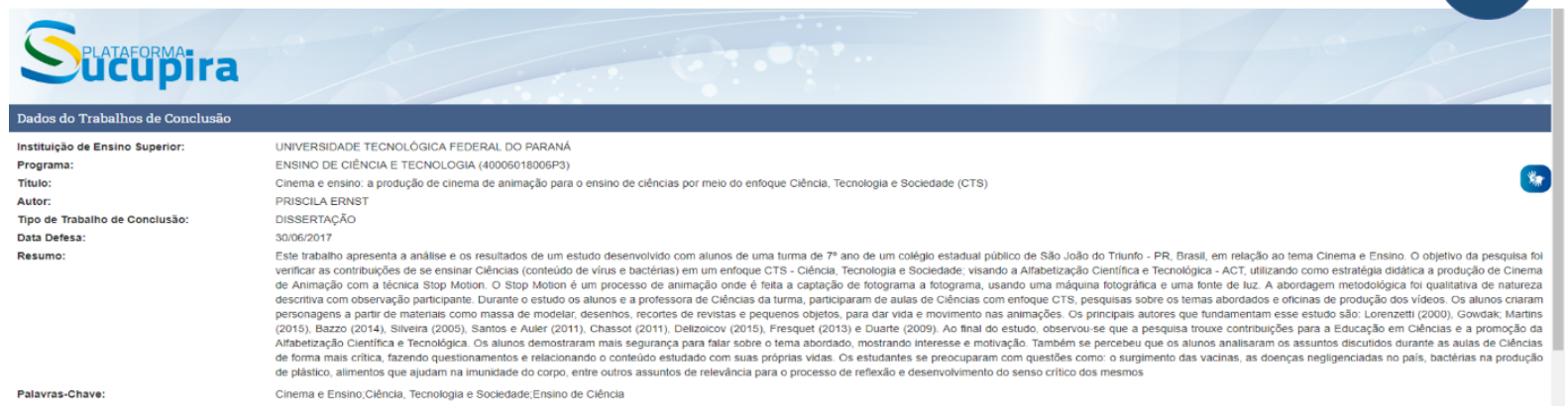

Sucrupipira

Instituiçăo de Ensino Superior:

Programa:
Titulo:

Titulo:

Tipo de Trabalino de Conclussio.

Data Detesa:

UNVERSIDADE DE SÃO PAULL

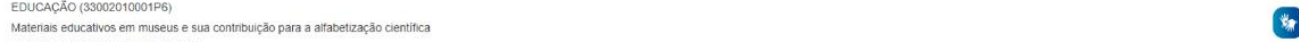

Resumo:

Palavras-chave:

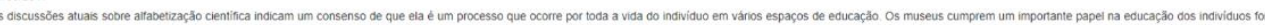

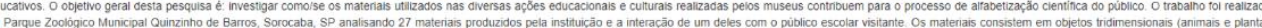

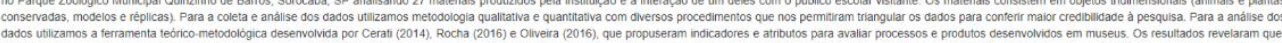

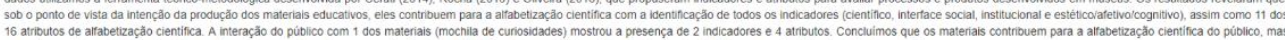

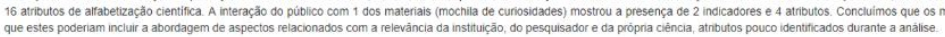

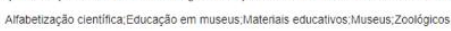

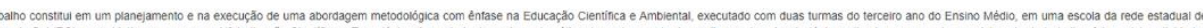

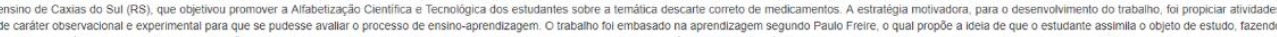

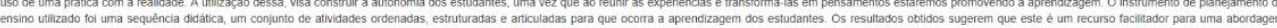

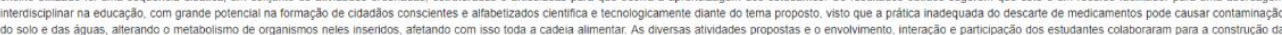

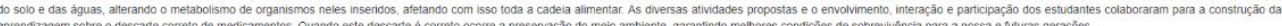
ELSON SILVA DE SOUSA

$\begin{array}{ll}\text { Tipo de Trabalho de Conclusăo: } & \text { DiSSERTAÇÁO } \\ \text { Data Defesa: } & \text { 15/12:2017 }\end{array}$

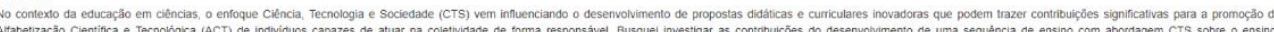

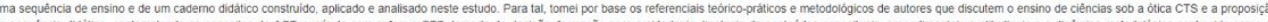

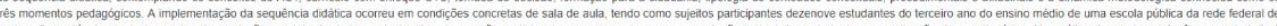

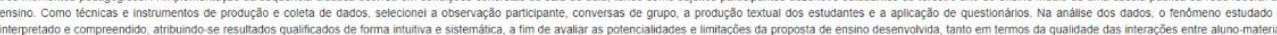

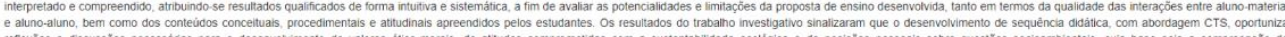

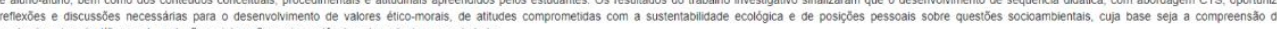




\begin{tabular}{|c|c|}
\hline \multicolumn{2}{|c|}{ Dados do Trabalhos de Conclusāo } \\
\hline Instituiçăo de Ensino Superior: & INSTTUTO FEDERAL DE EDUCAÇÁO, CIIENCIA E TECNOLOGIA DO ESPIRITO SANTO \\
\hline $\begin{array}{l}\text { Programa: } \\
\text { Titulo: }\end{array}$ & 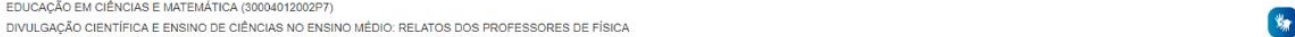 \\
\hline Autor: & FREDERIC ANDRE ROBERT VAILLANT \\
\hline Tipo de Trabalho de Conclusiä: & DISSERTAČ̈̄o \\
\hline Data Defesa: & 26/10202017 \\
\hline Resumo: & 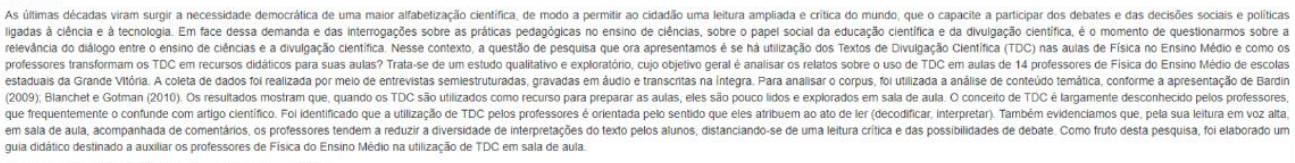 \\
\hline Palavras-Chave: & 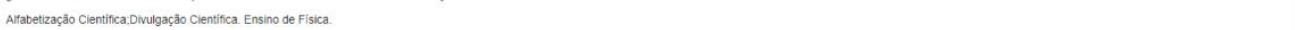 \\
\hline
\end{tabular}

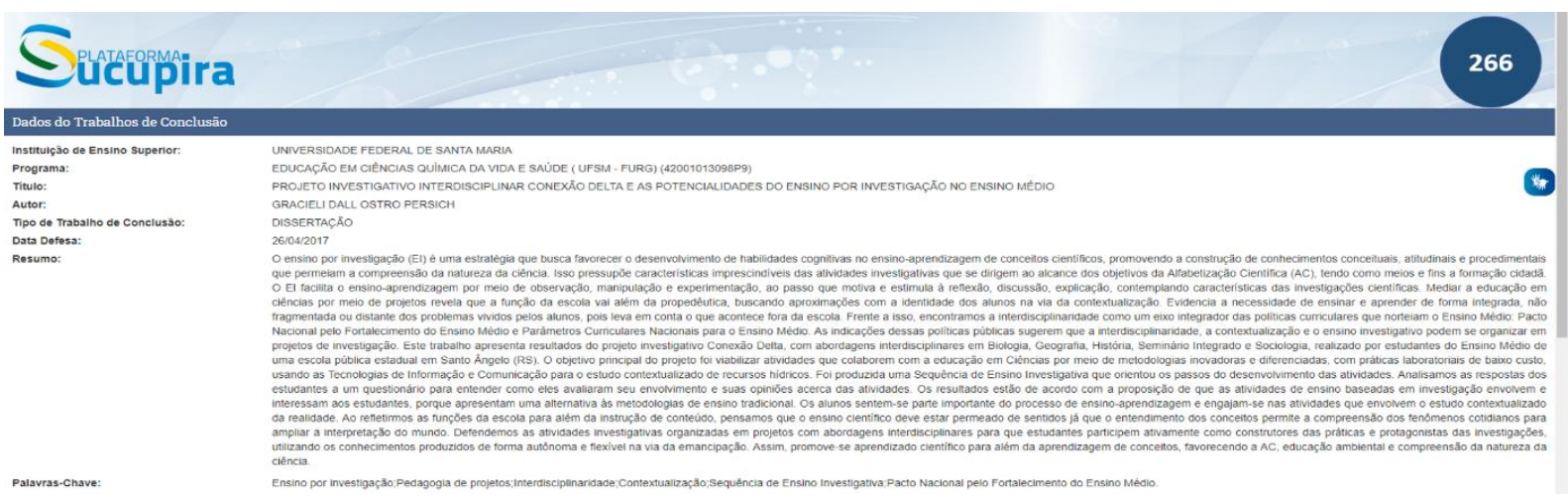

\section{Dados do Trabalhos de Conclusäo}

Institulusalo de Ensino superior:

Programa:
Titulo:

Autor:

Apo de Trabalho de Conclusio:

Data Detess:

\section{UUNDAÇ̃̃O UNIVERSIDADE FEDERAL DO PAMPA}

Ensino de Clènclas ( 420406017006 P 5 )

ZUIMICA NO ENSINO FUNDAMENTAL INVESTIGANDO QUESTÖES AMBIENTAIS EM UMA LLA INTERDISCIPLINAR DE RACIONALDADE

MLENE FERREIRA MLETTO

DISSERTAÇĀO

24:04:2017

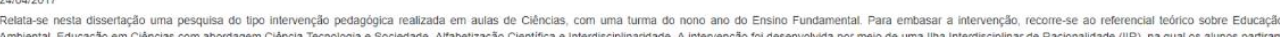

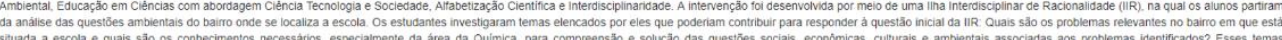

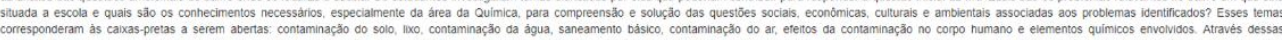

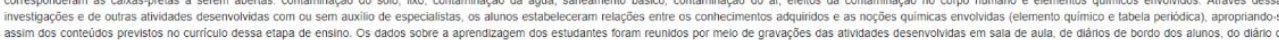

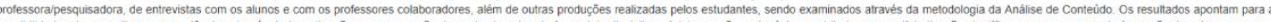

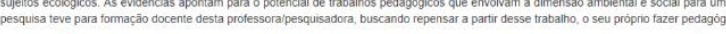

\section{Surcupira}

Instituigăa de Ensino Superior:

Programa:

UNVERSIDADE FEDERAL RURAL DO RIO DE JANEIRO

EOUCACĂO EM CIENCIAS E MATEMATICA (31002013156PA) DRIENE DA SILVA CARVALHO

DISSERTAÇĀO

Tipo de Trabalho de conclusa:

Data Defes:

29:09:201

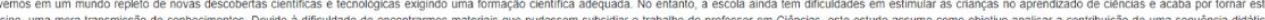

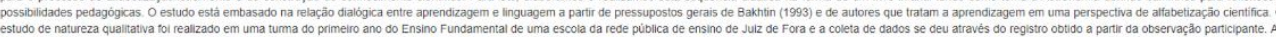

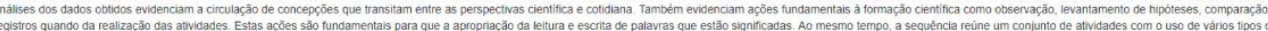

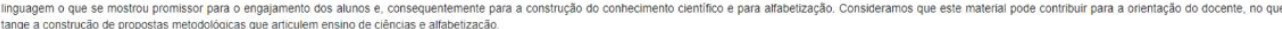



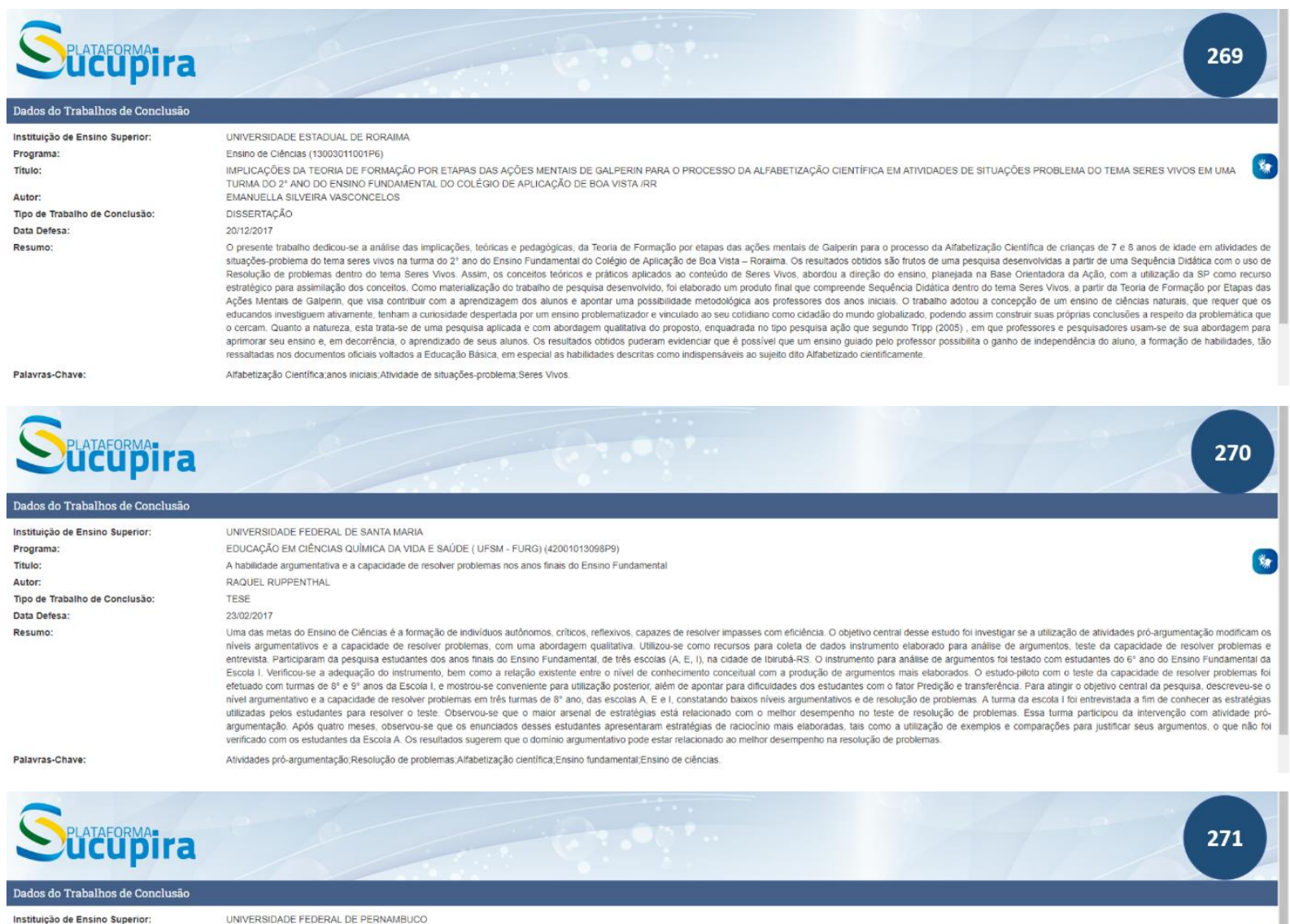

Programa:

Antor:

Tipo de Trabaliho de Conclusaio:

Data Detes:

Palavras-chave:

\section{WIVERSIDADE FEDERAL DE PERNAMBUCO}

EOUCAC̆ÖO (25001019001P7) GELSON NUNES DE OLIVERA JUNIOR

DISSERTAÇÄO

06022017

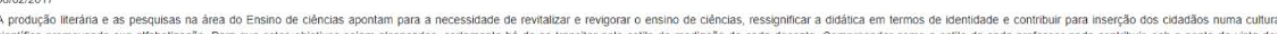

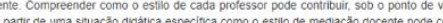

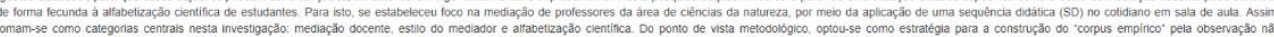

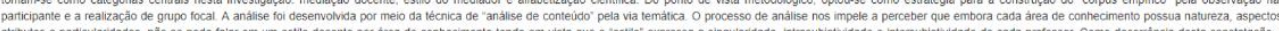

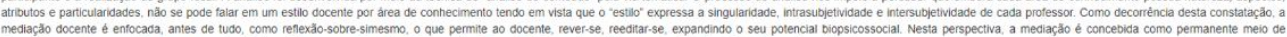

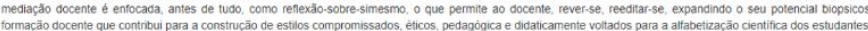

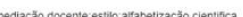

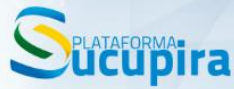

UNDACGÁO UNIVERSIDADE FEDERALL DE SERGIPE

Ensino de Fisica- PROFIS (33283010001P5)

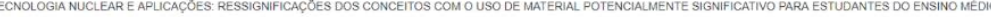
MAGDA DIAS DE OLNEIRA SANTOS DISSERTACAO O 11082017

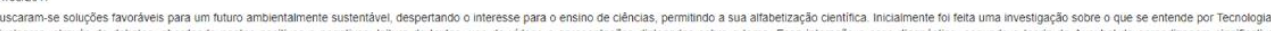

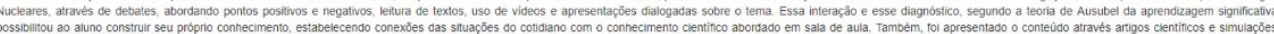

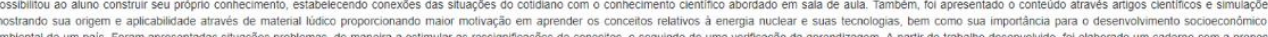

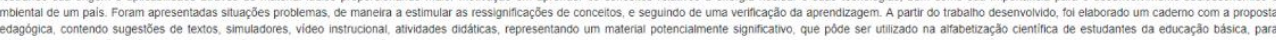
istimular a transposiçajo didabica de saberes da àrea nucleare suas apilicaçées 


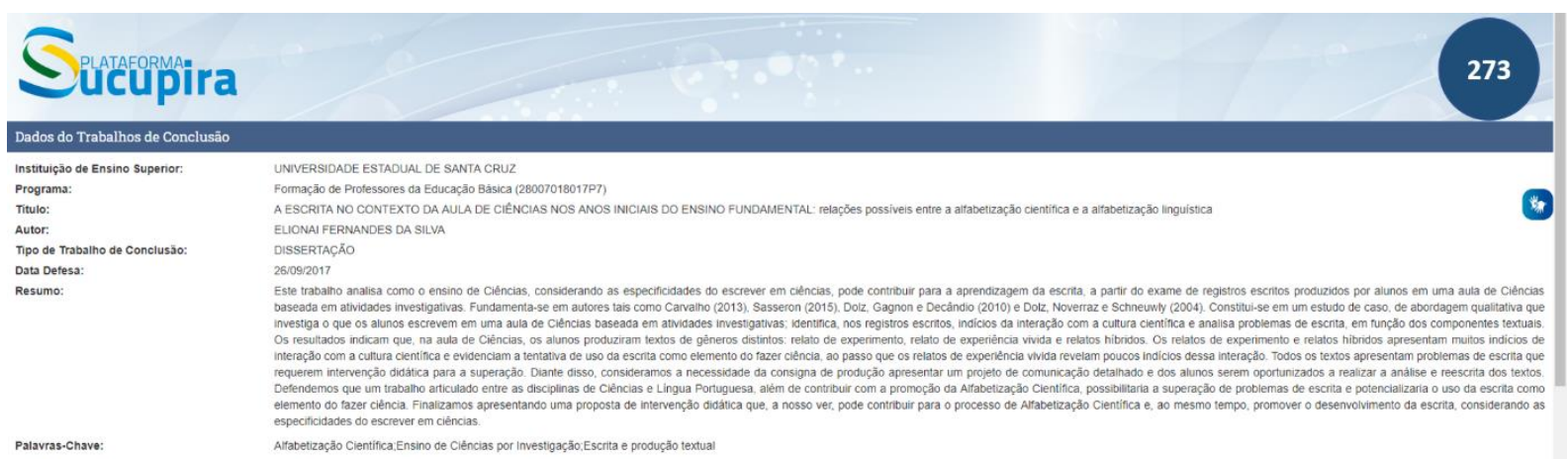

\begin{tabular}{|c|c|}
\hline \multicolumn{2}{|c|}{ Dados do Trabalhos de Conclusẫo } \\
\hline Instituiģāo de Ensino Superior: & UNIVERSIDADE ESTADUAL DE MATO GROSSO DO SUL. \\
\hline $\begin{array}{l}\text { Programa: } \\
\text { Titulo: }\end{array}$ & 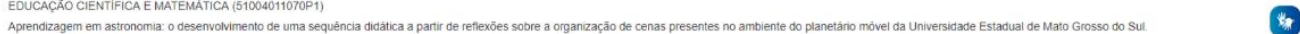 \\
\hline Autor: & 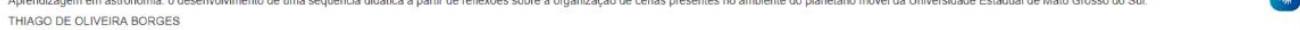 \\
\hline Tipo de Trabalino de Conclusso: & DISSERTAÇ̄̃o \\
\hline Data Defess: & O1/12:2017 \\
\hline Resumo: & 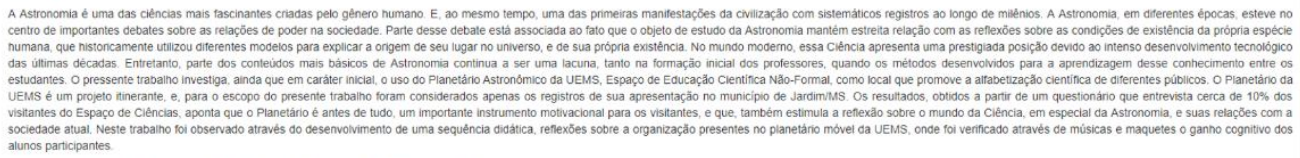 \\
\hline Palavras-chave: & 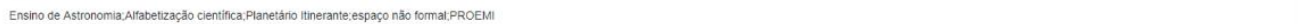 \\
\hline
\end{tabular}
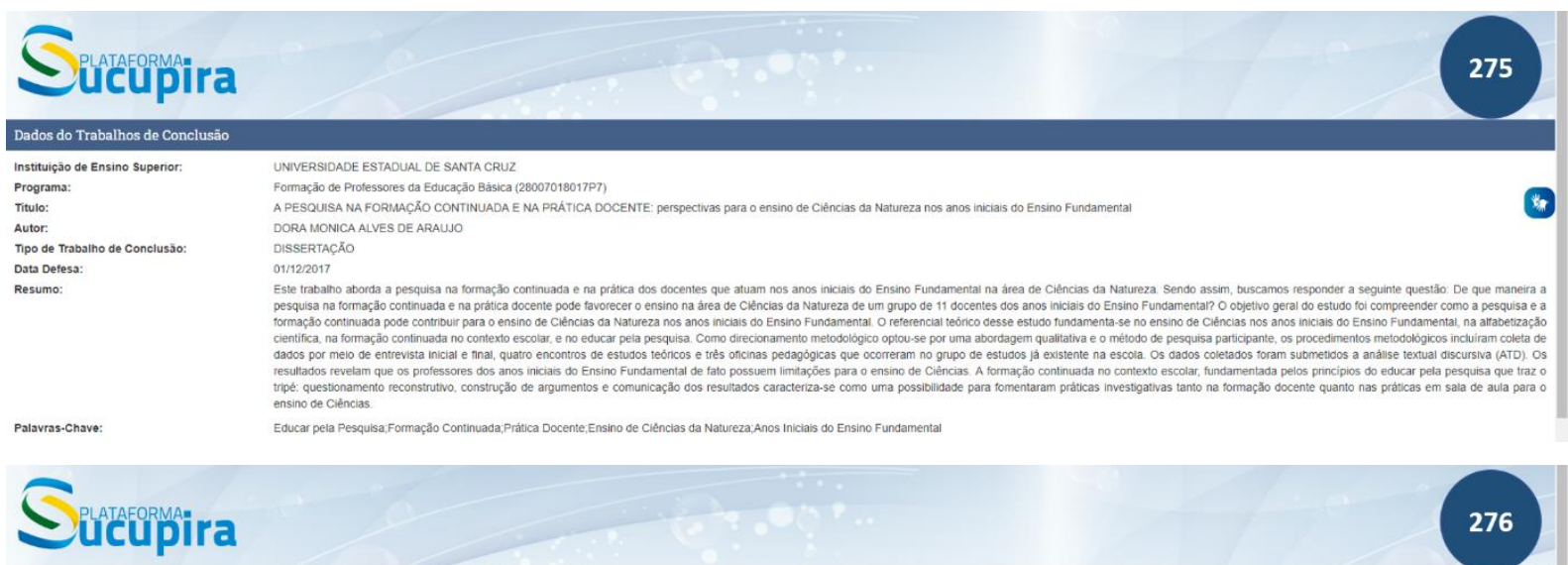

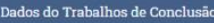

Instituiģ̧ä de Ensino Superior: Programa:

Titulo:

Tipo de Trabalho de Conclusäo: Data Detesa: Resumo:
UNIVERIDADE FEDERAL DE GOLÁS

Ensino de Fisica-PROFII (33283010001P5)

GUSTAVO ALMEIDAE SIIVA.

DISSERTAC̄̃o
15:03:2017

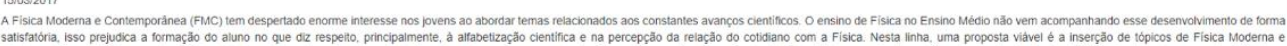

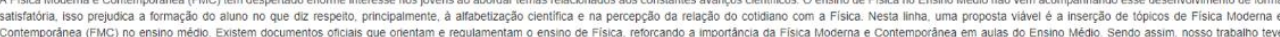

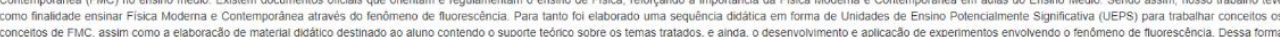

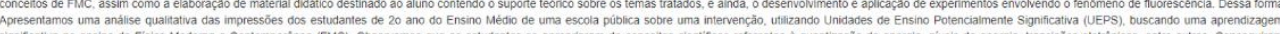

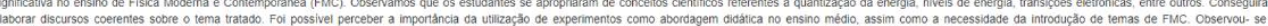

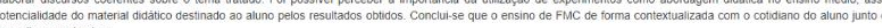

